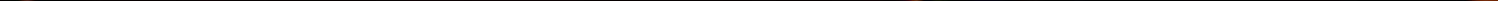




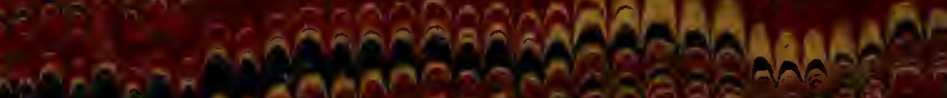

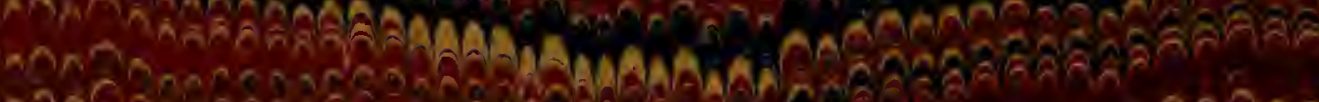

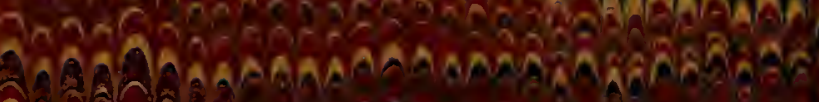

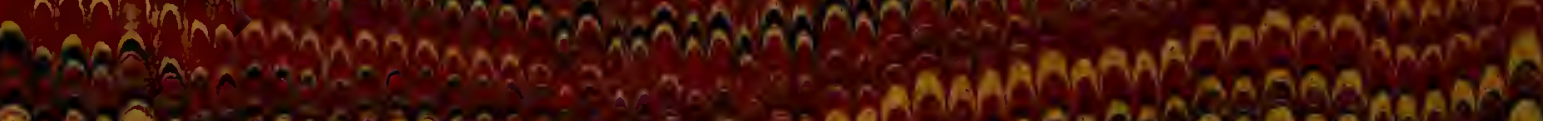

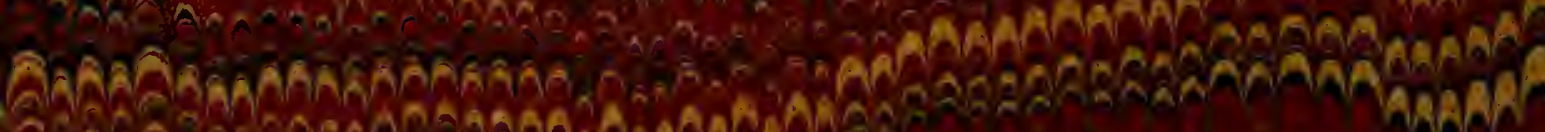

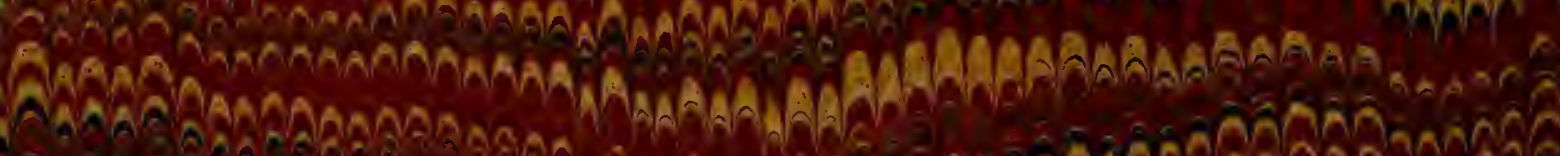
Ahapia

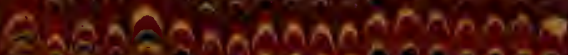

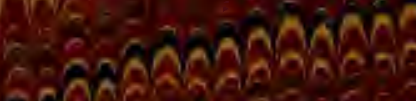

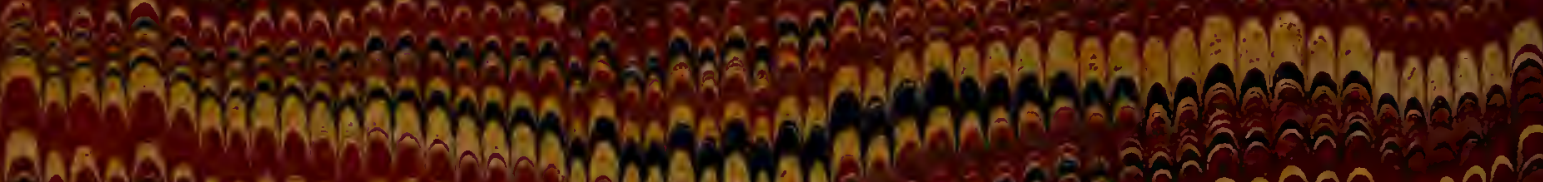

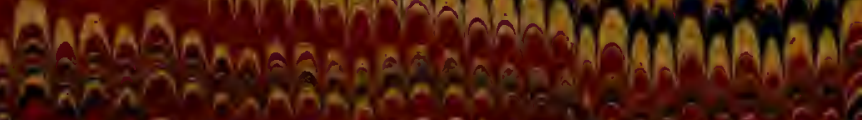

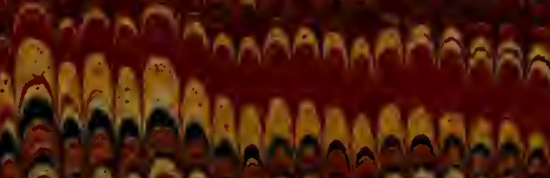

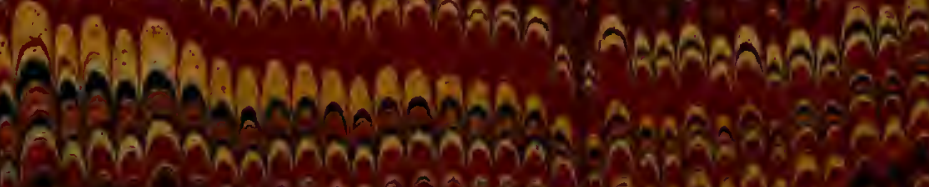

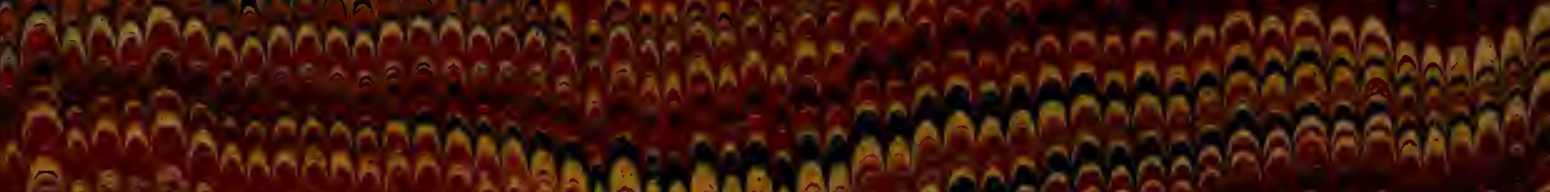

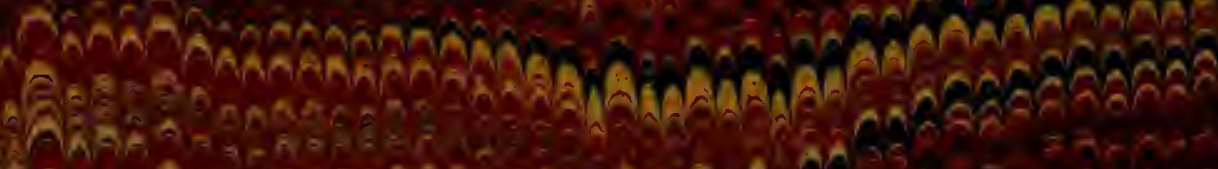

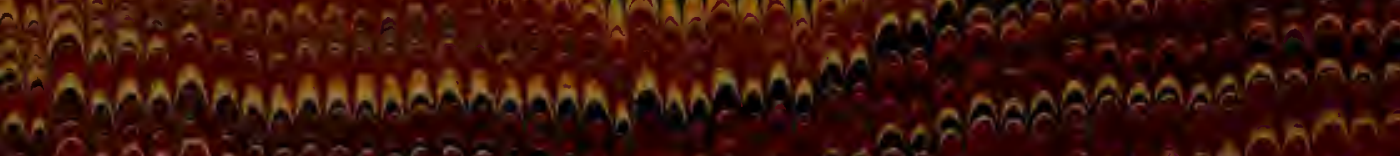

7. 000

A

A:

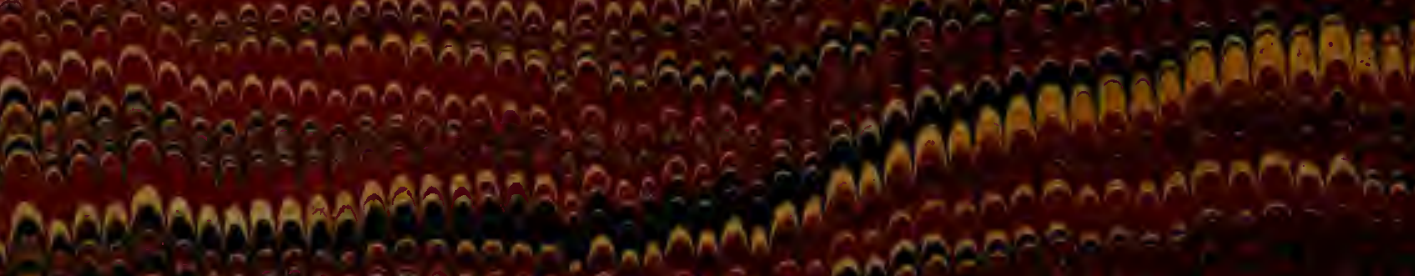

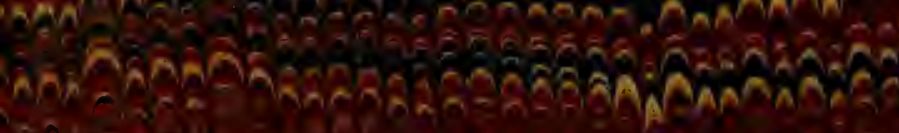

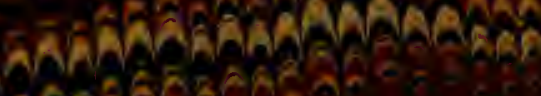







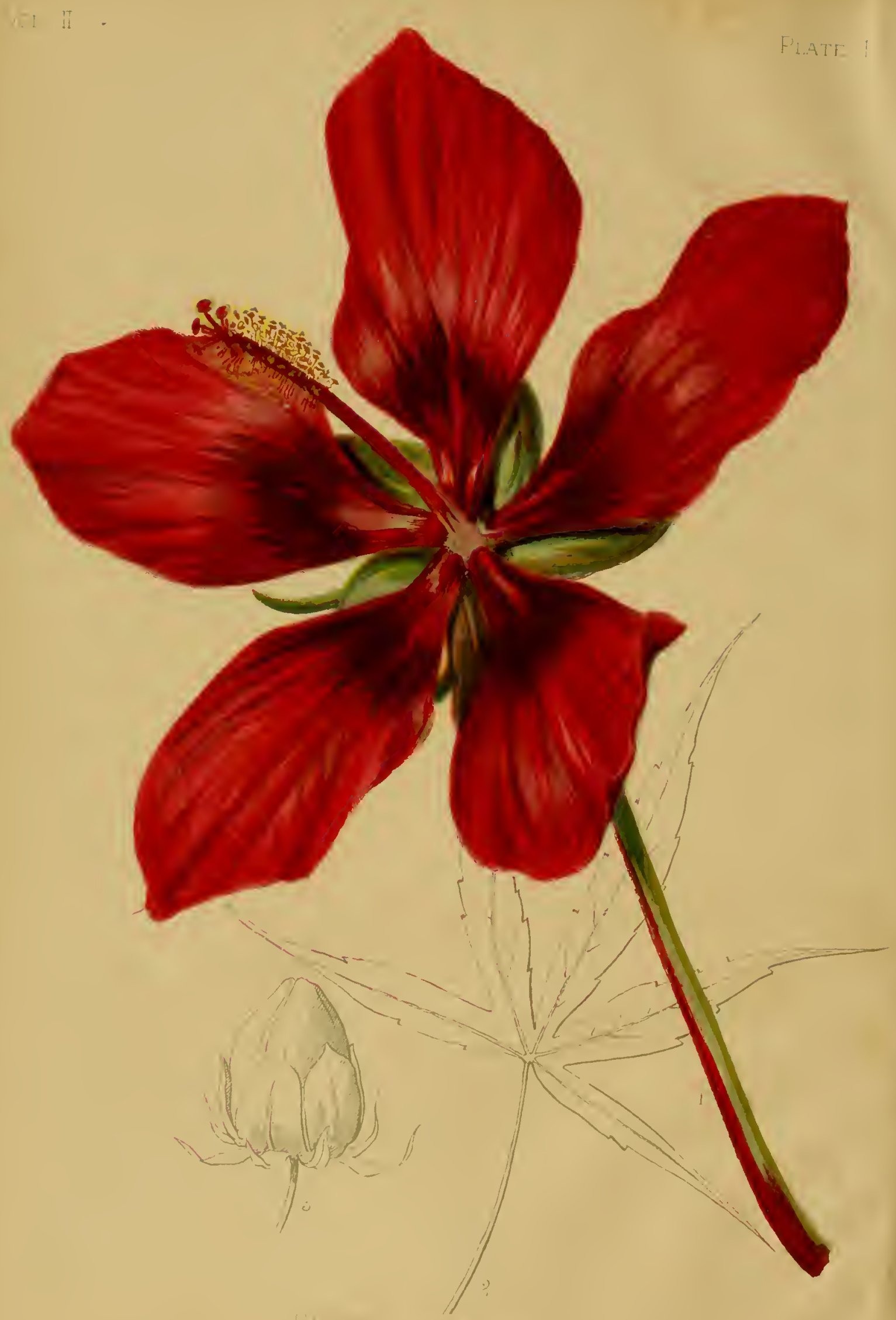




\title{
NATIVE FLOWERS AND FERNS \\ OF THE UNITED STATES
}

\author{
IN THEIR BOTANICAL, HORTICULTURAL, AND \\ POPULAR ASPECTS.
}

13 $\mathrm{Y}$

THOMAS MEEHAN,

PROFESSOR OF VEGETABLE PHYSIOLOGY TO THE PENNSYLVANIA STATE IOARD OF AGRICULTURE, EDITOR OF THE GARDENERS' MONTHLY, ETC., ETC.

VOLUME II.

IIIUSTRATED BY CIIROMOI,ITHOGRAPIIS.

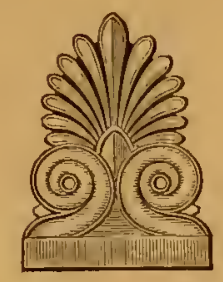

BOSTON :

L. PRANG AND COMPANY.

I 879 . 



\section{CONTENTS OF VOLUME II.}

Hibiscus COCCINEUS.

PAGR

American Scarlet Kose-Mallow . . . . . . . . . I

Callirriót inVolucrata.

P'urple P’oppy-Mallow

Campanula rotundifulia.

Bluebell of Scotland

Marsilia guatififolia.

Four-Leaved Marsilia

SILENE VIRGINIC..

Virginian Catchly . . . . . . . . . . . . 17

VITIS INDIVISA.

Entire-Leaved Ivy-(irap?

I POMGE LETTOPHYLA.

Colorado Man-Root

ANTENNARIA MAANTAGINIFOLIA.

Mouse-Ear Everlasting .

RosA LUCIDA.

Dwarf Wild Rose . .

HeLENIUM TENUIFOLIUM.

Slender-Leaved Sneezcwor:

SCUTEllaria WRighti.

Wright's Skullcap .

Silene steIllata.

Starry Campion, or Catchfly .

STOKESIA CYANEA.

Blue Stokesia. 
TALINUM TERETIFOLIUMI.

Terete Talinum ; Fame-Flower . . . . . . . . . 53

LYSIMACHLA QUADRIFOLIA.

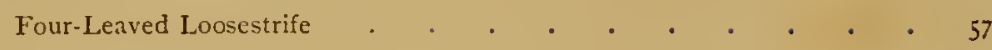

RHEXIA VIRGINICA.

Meadow-Beauty . . . . . . . . . . . 6r

ASPLENIUM PARVULUM.

Smaller Ebony Spleenwort . . . . . . . . . . 65

Amaryllis Atamasco.

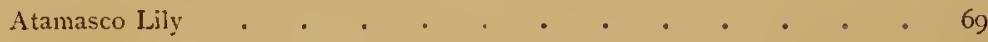

Mimulus Jamesiz.

James' Monkey-Flower . . . . . . . . . . . 73

BRODIEA GRANDIFLORA.

Large-Flowered California Ilyacinth . . . . . . . . 77

VERBENA AUbletia.

Aublet's Verbena . . . . . . . . . . . . 8 I

HYPOXIS ERECTA.

Star-Grass . . . . . . . . . 85

RUEllia CILIOSA.

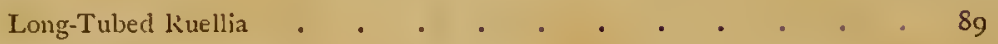

Eptphegus Virginiana.

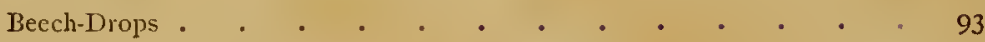

IPOMEA IACUNOSA.

White-Star Ipomøa _ . . . . . . . . . . . 97

Calopogon pulchelius.

Grass-Pink . . . . . . . . . . . . . IOI

ORONTIUM AQUATICUM.

Golden Club . . . . . . . . . . 105

VACCINIUM M.ICROCARPON.

American Cranberry . . . . . . . . . . . . rog

HELENIUM AUTUMINALE.

Autumn Sneezewort . . . . . . . . . . . II3

THIA.ICTRUM ANEMONoIDEs.

Wind-Flower Meadow-Rue . . . . . . . . . . II7

VYRNONIA NOVEBORACENSIS.

Iron-IVeed; Flat-Top . . . . . . . . . . . I2I

PrROLA ELLIPTICA.

Wintergreen; Shin-Leaf . . . . . . . . . . 125 
ECHINOCACTUS POLYCEPHALUS.

PARONYCHIA ARGIROCOMA.

Silverhead; Nailwort . • • • • • • • • • • 133

Gymolomia Porteri.

Stone-Mountain Star • • • - • • • • • • 137

EPIDENDRUM CONOTSEUM.

Jartram's Tree-Orchis . . . . - . . . . . . IfI

Heliantius Maximliand.

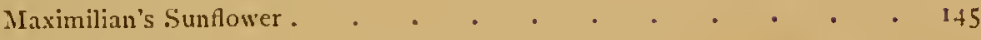

ASTIDIUM ACROSTICHOIDES.

Christmas Shield-Fern . . . . . . . . . . . I 49

Polygonum ARIFOLIUM.

IIalberd-Leaved Tear-Thunb . . . . • . . . . 153

Medeola Virginica.

Indian Cucumber . . . . . . . . . . • 157

Polypodum vulgare.

Common Polypocly . . . . . . . . . . . 16I

Collinsonia Canadensis.

Collinson's Flower . . . . . . . . . . . 165

Phaseolus diversifolius.

Diverse-Leared Kichey-liean . . . . . . . . . I 169

UVULARIA SESSILIFOLIA.

Sessile-Leaved liell-Wort . . . . . . . . . . 173

ASPLENIUM ETENEUM.

Ebony Splecnwort . • . . . . . . . . . . 177

Gaillaknia ambigrodo.v.

Blunt-Tooth Blanketfiower . . . . . . . . . . is

ANDROMEDA Mariaxa.

Stagger-Bush . . . . . . . . . . . is $_{5}$

Cerastium ARVENSE.

Ficld Mouse-Ear Chickweed . . . . . . . . . . ISg

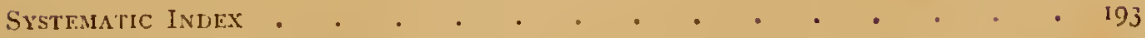

INDEx of botavical NaMis - • • • • • • • • • • • 197

INDEX OF COMMON NAMES 





\title{
HIBISCUS COCCINEUS.
}

\author{
AMERICAN SCARLET ROSE-MALLOW.
}

NATURAI, ORDER, MAIVACEA.

Hiniscus coccineus, Walter. - Sinooth; stem glaucous; leaves long-petiolect, five-parted to the base, the lobes lanceulate, remotely toothed, with lung-tapering entire tips; curolla expanding, bright scarlet; petals long-clawed; seeds pulcscent. Sitems four to cight fect high. Leaves six to twelve inches long. Corolla six to eight inches wicle. Column of stamens naked below. (Chapman's Flori of the Southern ('rited Stutis. Sec also IVood's Class-Book of Botany.)

HE natural order to which Hibiscus coccincus belongs is [20.9 of immense value to man. Cotton, which has been called the king of all agricultural products, in a commercial sense, is a member of this order; and many of its other representatives are also employed in textile industry. The species which are comprised in it have a close family resemblance; or, as it would be technically styled, the order is a very natural one. The union of the stamens into a tube, leaving only the upper portion of the filaments with the anthers free, the whole surrounding the pistils, is eminently characteristic of Malvacec; and although other orders, Gcraniacca for instance, have a somewhat similar arrangement of stamens, there are yet certain attendant circumstances which are always present, and which will prevent the confusion of Malvacer with any other family. The nearest relationship in structure to Malvacea is perhaps shown by Tiliacer, the order to which the linden belongs; but the difference in the general appearance of the two is so great that even the umbotanical observer will find no difficulty in deciding between them. It is hardly necessary to say that Malvacee belongs to the polypetalous division of exogens; but there 
may be danger occasionally of the student's mistaking some of the species belonging to the order for monopetalous plants, as in many of the genera all the petals fall simultancously. This, however, is owing to the fact that the petals are held together by the united mass of filaments with which they are connected at the base. Close examination will invariably show that they do not touch, - that they are really separate from one another, and that therefore all the flowers belonging to the order are indeed polypetalous. In some of the Malvacce the seeds are apparently naked, while in others they are cnclosed in a pod, and this might perhaps be looked upon as a striking difference; but the student of morphology readily understands that this difference is much more apparent than real, and is of use only as a distinction by which the order can be conveniently divided.

Our present genus, Hibiscus, which belongs to the pod-seeded section, forms a very important division of the family, having more species than Malva (from which the name Malvacce is derived), or than Sida, even if the numerous species into which some botanists have divided this genus be allowed to stand. The three together comprise a great part of the order.

The name Hibiscus is regarded as of uncertain derivation; and Dr. Gray simply says it is "an old Greek and Latin name of unknown meaning." In Latin writers we meet with Hibiscus, Hibiscum, and Ibiscum, three terms which are evidently identical, and refer to some swamp-plant. Paxton, reasoning from the orthography of the last of these terms, suggests that "the name is probably derived from ibis, a stork, because that bird is said to eat some of the species." But according to the ancient writers the ibis cared much more for frogs and marsh reptiles than for vegetables, and the etymology suggested by Paxton is not therefore very probable. It seems more likely that the genus was called Ibiscum, that is, literally "with the ibis," from some species which, like the $H$. pentacarpos, inhabited marshes, and that the name was simply intended to express the companionship of the 
bird and the plant which thus dwelt together. The specific name, coccincus, signifies "of a scarlet color," and needs no argument to explain it.

In most European works our species is called Hibiscus spcciosus, under which name it is figured in the tenth volume of Curtis's "Botanical Magazine," and described by Aiton in "Hortus Kewensis." Torrey and Gray have, however, shown that the name $H$. coccincus, as given by T. Walter, who in $17 S S$ published the "Flora Caroliniana," existed prior to H. spcciosus, and in botanical nomenclature priority rules. Walter's name is therefore in universal use by the American botanists of our time.

Hibiscus coccincus is probably the most gorgeous of all the plants indigenous to the United States. It is very little inferior in the brilliant show it makes to the celebrated Chinese Rose Hibiscus, not uncommon in our green-houses. Curtis was particularly struck by its gay appearance, and in the volume above referred to he says: "Those who 'admire nature's clocks more than her watches' will view, we presume, with some pleasure our representation of this very superior species of Hibiscus, a native of North Carolina, and cultivated here by Dr. John Fothergill in 17S8." It is probable, however, that the plant was introduced into England some time before the date just mentioned, for in a letter by Peter Collinson to Wm. Bartram, dated Feb. 16, 1 76S, and published in Darlington's "Memorials," we read: "The crimson Hibiscus is a charming flower. I could have no perfect idea of it but from thy elegant painting. Pray desire thy father (John Bartram) to spare no pains to get us seeds from Charleston, where I dare say it ripens seeds."

Like many other plants which are naturally found in swampy places, the Hibiscus coccincus not only does not object to, but indeed rather enjoys a transfer to drier locations. In the paragraph from the "Botanical Magazine," we have read that it grew in English gardens in the last century, although it does not seem to be common there now. The writer of this has seen 


\section{HIBISCUS COCCINEUS. - AMERICAN SCARLET ROSE-MALLOW.}

it in the gardens of Tennessee, in common garden borders, and in comparatively dry situations. Even in the cooler North it does well, as shown by the specimen from which our drawing was made. This specimen came from the Botanic Garden of Harvard University, at Cambridge, Mass., and was kindly furnished by Prof. Sargent. Some of the English writers complain that the plant does not ripen its seed well in their country; but the summers in all parts of our own territory (except Alaska) are probably warm enough for the production of ripe seed. The sister species of our plant, the Hibiscus Rosa-Sincusis of our gardens, has yielded many varieties, - yellow, orange, crimson, and other hues, - besides double as well as single flowers, and if similar attention were shown to $H$. coccineus, the florists would no doubt be rewarded by similar results.

There are no special medical virtues attributed to our species, nor is it of any known use in the arts, although, doubtless, it has some useful qualities in common with other species of the same genus. In China, the ladies, instead of priding themselves on the whiteness of their teeth, color them black, and the dye which they employ for this purpose is said to be made from the petals of the Rose Hibiscus. In all probability the petals of our Scarlet Hibiscus possess the same property, and when the Chinese have become numerous enough in America to create a sufficient demand, some enterprising business man may perhaps put this hint to practical use by establishing a "toothdye " manufactory.

According to Dr. Chapman, the Scarlet Hibiscus grows in " deep marshes near the coast, Florida, Georgia, and westward."

Explanation of the Plate. - I. Fully developed flower. - 2. Outline of leaf much reduced. - 3. IIalf-mature capsule with the involucre. 



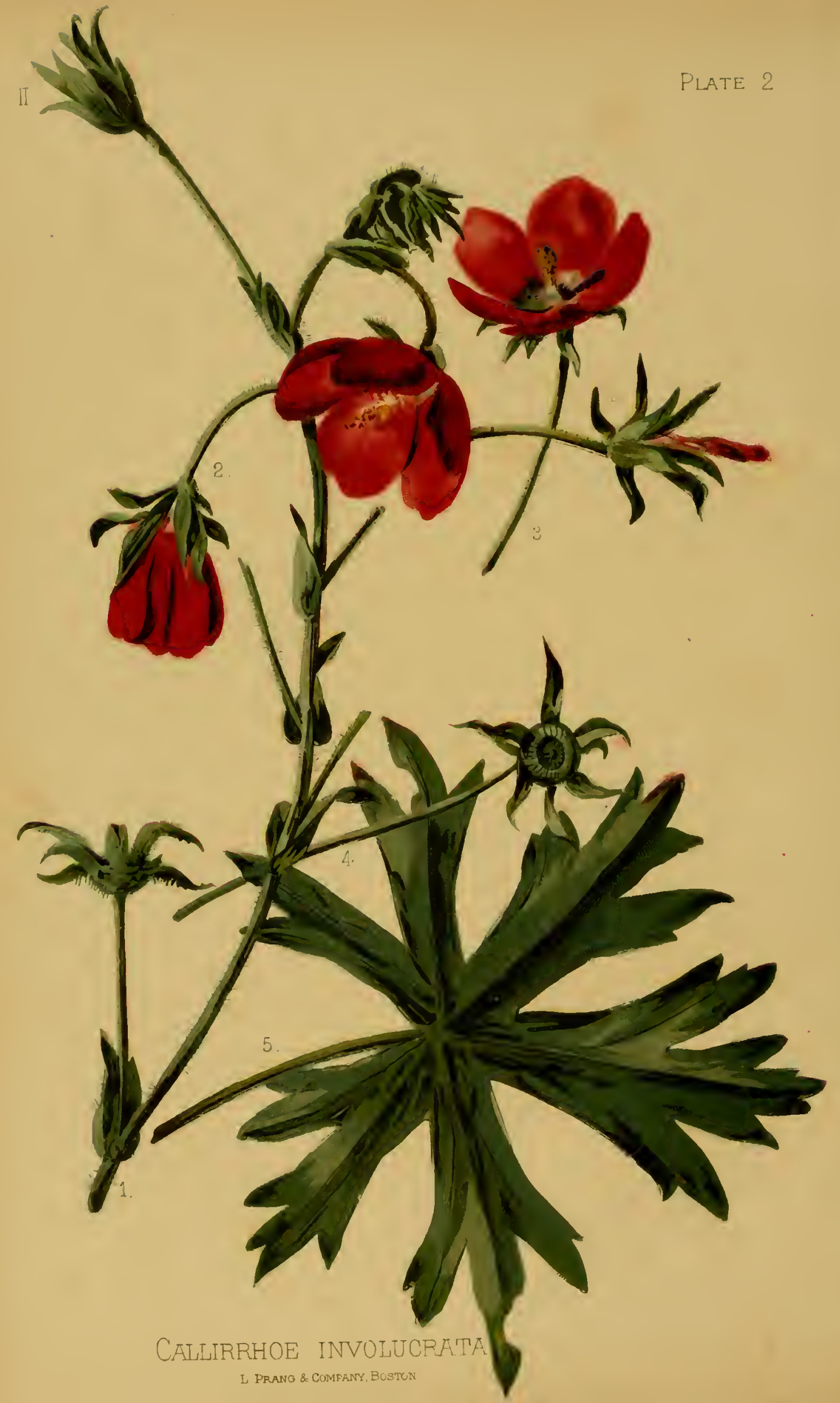




\title{
CALLIRRHOE INVOLUCRATA.
}

\author{
PURPLE: POPPY-MALLOW.
}

NATURAl, ()RIER, MALVACFA:

\begin{abstract}
Callirkhui involucrats, Asa Gray.-Stems spreading on the ground, one to three feet long; stipules conspicnous; leaves rounded, five-parted or cleft and eut-lubed, shorter than the axillary peduncle; involucre shorter than the enlyx; corolla two inelies or more broad; carpels of the fruit reticulited, tipped with a flat and inconspicuous lueak. (Ciray's Fidd, Forcst, and Girden Bolany. Sce aiso Porter's Florid of Colorido, and Torrey and Gray's Flora of North America, under Malat inzolucrala.)
\end{abstract}

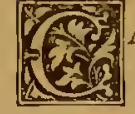

ALLIRRHÖ̈, says Dr. Gray, is "a Greek mythological meagre picce of information only whets the appetite for more, as cverybody is of course curious to know the precise reason why this mythological name was given to our flower.

According to the ancient legends, Callirrhö, "the beautifully flowing" (from two Greck words, signifying "beautiful " and "a stream," or "something flowing"), was a nymph of the sea, one of the daughters of Oceanus and Tethys, and after her was named a beautiful fountain at $A$ thens, which exists to this day, and from which flow nine streams in different directions. As the flowering branches of our Callirrhö trail along the ground, and emanate from one central point, like so many pretty little streams starting from one fountain-head, it might be fancied that the name was suggested by the similarity to the "beautifully flowing" well at Athens.

Still another theory might, however, be advanced, connecting the name of the plant with that of one of its relatives, with which it was formerly associated in one genus. The first known species of the genus now called Callirrhö̈ was thought 
to be a Mallow, and Cavanilles, therefore, in a work on monadelphous plants, published in Paris about the end of last century, named it Malva Papaver, from the resemblance of its flowers to Papaver Rhocas, the common, classic Field-Poppy, or Corn-Rose, of Europe. If we accept this theory, we may suppose that Nuttall had the $P$. Rhocas in mind when he decicled on making a new genus for Malva Papaver, and hence our present name, the "Beautiful Rhœas or Poppy." If some inquisitive mind should still be unsatisfied, and should go further and ask how the Corn-Rose came to be called Rhocas, he would find himself involved in new difficulties, as some maintain that the name is derived from rhodon, the Greek word for rose, while others connect it with the fact that the Field-Poppy "overflows" all the corn-fields and waste places.

The reasons which induced Nuttall to separate these plants from Malva are given by him in the "Journal of the Academy of Natural Sciences of Philadelphia," for i 821 . In the true Malvas there are always three involucre-like bracts beneath the flower, while in Callirrhö̈ we find frequently only two or one, or even none at all; but this character, being changeable, is of little value. Our present species, indeed, always has three bracteoles, as we see in the plate (Fig. 2), and to this peculiarity, which is exceptional in the genus, it owes its specific name, involucrata. A better-marked distinction is found in the fruit. In Callirrhö̈, as stated by Dr. Gray in his "Field, Forest, and Garden Botany," the carpels have a sort of beak at the summit, while Malva has the carpels beakless. Some European botanists, however, do not regard these distinctions as sufficient to make them the basis of different genera, and therefore employ them merely as characteristics of a subdivision of true Maluas.

Those who wish to cultivate the Purple Poppy-Mallow, as our plant is commonly called, will find it very easily managed. Mr. Robinson, of London, praises it very highly, in his "Hardy Flowers" for English gardens, naming it as specially well adapted for rock-work, for which its trailing habit and its ability 
to live in hot, dry places peculiarly fit it. Its beautiful flowers must show to great advantage when it is grown as suggested by Mr. Robinson. In American gardens it is chiefly used as a border-plant, in which capacity it receives great praise from Mr. Vick, of Rochester, N. Y., and Messrs. D. M. Ferry \& Co., of Detroit, Mich., in whose grounds, as well as in those of the writer, it does well with little care. Mr. Ferry likens the flower to "a portulaca in form and color." Mr. Vick finds that the seeds grow freely, sown in the open ground, and that the seedling plants will bloom the first year, the plant being a perennial. The specimen from which our drawing was made was grown at the Bussey Institute, under the hands of Mr. Jackson Dawson, head gardener of the Arnold Arboretum. Plants growing in the writer's garden, kindly supplied by Mr. Sternberg, of Fort Hays, in Kansas, have the root-leaves less deeply lobed.

Malvaceous plants are generally beautiful, and some are quite celebrated for the fibres which they afford for textile fabrics, but only few of them are known for their qualities as edibles. The immature seed-vessels of the okra are perhaps the best known of malvaccous vegetables. It is not unlikely, however, that the culinary list of these plants might be largely extended. Children gather and eat the unripe fruit of Malva rotundifolia, and although this is probably done more in play than because these seed-vessels are really a peculiar relish, the fact still shows that the plant is not unwholesome, and that possibly the largerfruited kinds might be turned to some use as vegetables.

\footnotetext{
"Then sitting down when school was o'er Upon the threshold of the door, Picking from mallows, sport to please, The crumbled seeds we called a cheese."
}

Our present species also has a flat, circular fruit, resembling a "cheese," but its roots probably possess a still more substantial value. This fact seems to have been first noted by 
Stansbury, as recorded in his account of the expedition to Great Salt Lake, in i 849 . He says: "The valley of the Little Blue has not presented any great novelty in the way of flowers; but a splendid variety of the Mallow, of a bright carmine color, its trailing stems sending up flowers in little patohes a few yards square, presented a rich and beautiful appearance, enlivening the monotony of the prairies by its brilliant hues." In the valley of the Platte, he again speaks of meeting the "Purple Mallow," and adds that "the root resembles the parsnip, and is eaten by the Indians." It is singular that Fremont, who passed over the same ground a few years before, and gave great attention to the roots eaten by the Indians, makes no mention of those of our species, although he seems to have met with the plant on the Little Blue River of Kansas, the place where Stansbury first saw it. It appears, indeed, to have often been seen by the early explorers. Lindheimer found it "in oak-openings on the Pierdenales," in Texas, and Wright collected it "on the San Pedro and Pecos Rivers," in the same State. Fremont and Stansbury found it, as before stated, on the Little Blue River of Kansas, although the latter speaks of it chiefly as located on the "upper waters of the Platte." Whipple's Pacific Railroad Expedition saw it "on the Canadian," and the writer of this found it on the ridge dividing the Arkansas from the Platte regions. Prof. Porter, in his "Flora of Colorado," reports it on Purgatory River, and it is included in the collections made in the Rocky Mountains by Dr. Parry, in 1861. Mr. Ruffner, finally, finds it in Northern Texas, while Prof. Snow says it occurs in Kansas, but doubts whether it is distinct from Callirriö̈ Papaver.

These separate locations very well represent the whole district in which it has so far been found.

Expianation of the Plate - I. The terminal portion of a long trailing branch. - 2. The three involucral bracts, in addition to the usual five sepals. -3 Sieparate Hower, showthe monadelphous column of st:mens. - + Immature frutt, showing pesition of the minute beak in the centre of the carpels -5 Leal-blatd, with chief portion of the putiule 


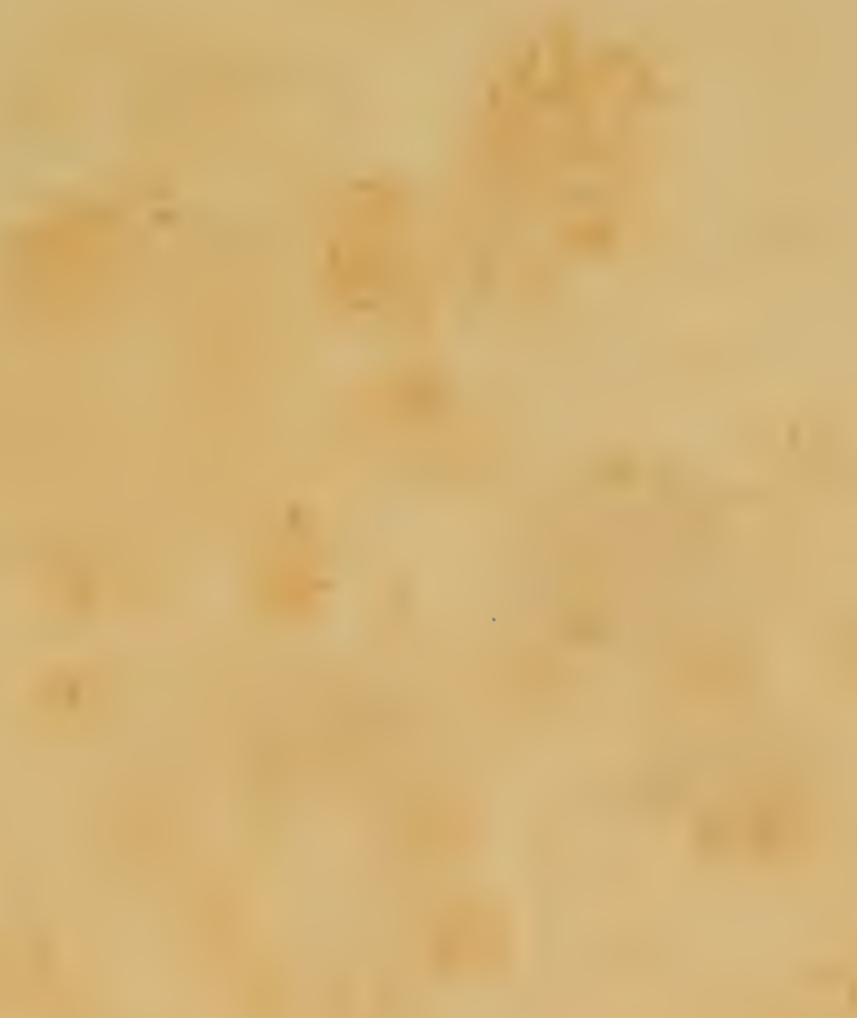




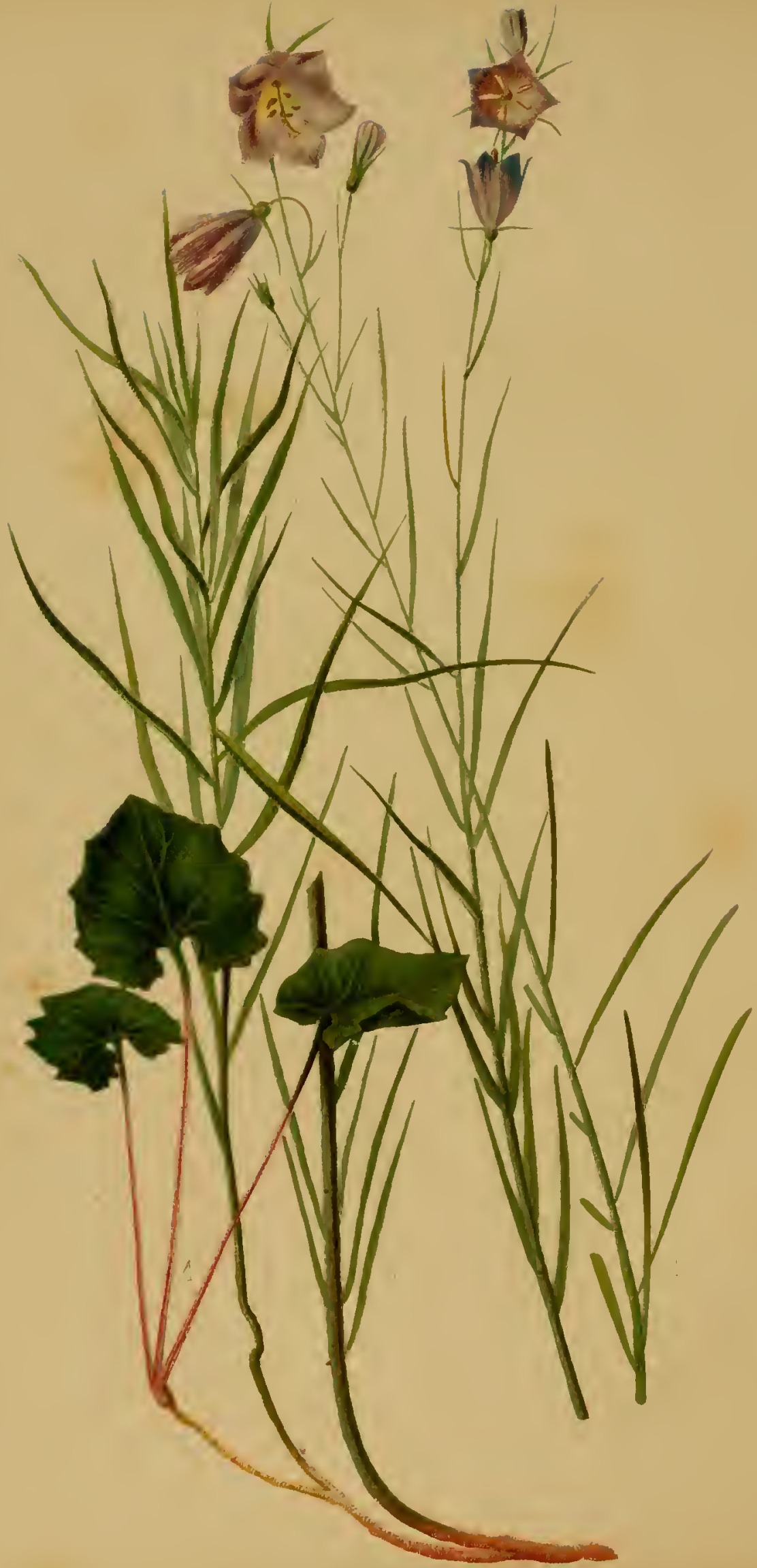




\title{
CAMPANULA ROTUNDIFOLIA.
}

\author{
BLUEBELL OF SCOTLAND.
}

NATURA1, OKLEK, CAMI'NULACEN.

\begin{abstract}
CAMPANULA ROTUNDIFOLI, Linnaus. - Silender, branching (five to twelve inches high), one to ten-flowered; root-leaves round-heart-shaped or ovate, mostly toothed or crenate, longpetioled, early withering away; stem-leaves numerous, linear or narrowly lancerolate, entirc, smooth; calyx-lobes awl-shaped, varying from one third to two thirds the length of the bright-bluc corolla (which is six to nine lines long). (Gray's.Manwal of tho Botany of the Northern Unitid Stutes. See also Wood's Class-Book af Botany.)
\end{abstract}

HE species to which this chapter is devoted is one of the 20. most interesting plants indigenous to America, - interesting, not only on account of its historical and poetical associntion, but also on account of the botanical lessons it affords. Its family name, Campanula, is quite an old one, and Linnæus, finding this name in use when he reconstructed botany, simply adopted it. Campanula is the diminutive of campana, an Italian word, and signifies a little bell. The name is quite appropriate, as the flowers of this family generally have a bell-shaped character. The specific name of our species, rotundifolia, or round-leaved, seems to us to be also very appropriate, although there is scarcely a modern botanist who does not feel it necessary to enter a protest against it. The name refers to the very characteristic root-leaves of the plant (shown in Fig. 4), which are seen only in spring and fall, and the protests alluded to are based on the transient nature of these leaves. Thus Nuttall writes in I 818: "It was called Campanula dicipions by Persoon, and well named decipicns by him, for there are very seldom any round leaves to be seen on the plant"; and Dr. Gray says, in the work from which we have taken our botanical description: 
"A most inappropriate name, since the round root-leaves are rarely obvious." The root-leaves of plants, however, usually afford very interesting characters, and never ought to be overlooked, if it is possible to find them. For this reason it seems to be quite proper to refer to them in specific names, as these latter will naturally suggest to the student that there is something to be looked for. Nor is the Campanula rotundifolia the only flower named from its root-leaves. In Arabis lyrata it is well understood that the root-leaves only are lyrate or pinnatifid, and Phytcuma orbiculata is another plant which may be cited in illustration.

Possibly the rapidity with which the root-leaves disappear depends on the location in which the plants grow. It is quite likely, however, that these leaves often exist when the flowering specimens are gathered, and that they are simply overlooked. Our drawing shows how this may happen. The plant - increases by creeping, underground stems, and the way in which it develops can be easily understood by studying the figure marked with the numbers 2, 3, and 4 on our plate. At 2, the flowering stem is shown, which was produced by the terminal bud of the previous year's growth of the underground stem. In the spring, this shoot had the appearance of Fig. 4, but as the flowering stem grew up, the root-leaves withered and died. Another growth was then made from the underground stem, the result of which we see in Fig. 3. This stem is barren, and seems to have had no root-leaves, but the leaves on the stem itself are decidedly broader than the linear leaves on the first shoot. The last shoot, finally, represented at 4, appears towards fall, and has root-leaves only. This shoot holds over till next spring, and then the development of the plant, as we have just sketched it, is repeated once more. It is evident from these remarks that the root-leaves can probably be found without much trouble, if only the flowering stem is carefully traced to the underground stem, and this again is followed up to its point of termination. The specimen from which our drawing was made, and which 
was gathered in Massachusetts, certainly shows that the rootleaves are not always entirely wanting when the plant is in flower, although they may not be on the shoot bearing the flowers.

The leaves of Campanula rotundifolia illustrate a very interesting phase of vegetable morphology. We know that all the various organs of a plant are simply modified leaves, and yet we seldom find a gradual transformation of one organ into another, the changes taking place, as a rule, rhythmically, or in leaps. So in our present species, there is no gradual transition from root-leaves to stem-leaves, but the change from the one shape to the other is accomplished all at once, although the difference between the two is very great. The change from the narrow, linear stem-leaves to the broad corolla is also very marked, and it is difficult to trace any relationship between the two. The little, thready underground stem, however, shows more regularity in its work. The flower-stem at 2 has very narrow leaves, the succeeding shoot (3) has leaves somewhat broader, and the last one (4) bears the broadest of all, as it produces the round rootleaves to which the plant owes its specific name. We conclude from this that at certain stages of the plant's growth the rhythmical cycles may either begin or terminate in a broad, foliaceous arrangement, and we may therefore look upon the corolla cycle or verticil as the analogue of the broader root-leaves, rather than as that of the linear leaves of the flowering stem. That this view is correct is proved by a case recorded by Prof. Peck, in the twenty-seventh "Annual Report to the New York State Museum." Plants of the Bluebell were found at Point Jarvis, N. Y., which had the usual narrow leaves on the stem, but which, instead of terminating in flowers, terminated in round leaves.

In the United States our species is found from the New England States southward to the northern parts of New Jersey and Pennsylvania, thence westward across the northern part of Ohio to Michigan and to Wisconsin, where it seems particularly 
abundant, and through Iowa and Nebraska to the foot of the Rocky Mountains. It reaches its most southern location in New Mexico, but from that point turns northward again, and is rather abundant in Oregon. Prof. Rothrock also found it in Sitka. The situations which it chooses differ in the various localities. Along the Hudson River it is chiefly found in the fissures of rocks, while in the northern parts of Wisconsin the sandy places along the lake-shores are its favorite haunts. In the Rocky Mountains, however, it takes to the rocks again.

The common name of Campanula rotundifolia is frequently given as Harebell. All old English writers, however, apply the name Harebell to the wild English Hyacinth, Hyacinthus non-scriptus; and to this plant the name is rather appropriate, as in the early spring it is the favorite cover for hares. We have therefore adopted the name "Bluebell of Scotland," by which name it is generally known in English poetry, although Scotland cannot claim the privilege of being the exclusive home of the plant.

The confounding of the true Harebell with the Bluebell of Scotland has been the cause of many contradictions among the emblematists, so that some dedicate our flower to "grief," while others look upon it as the personification of "delicacy," and of "loneliness." Much of the poetry called forth by the Harebell also has nothing to do with our flower. Marie Roseau, however, probably had our plant in view when she wrote:-

"The dainty little Harebell

Is pleasant to the sight,

With its tiny azure petals,

And stem so long and slight."

The expression, "petals," will hardly answer to the monopetalous corolla of the Bluebell of Scotland, except with a poet's license; but otherwise the picture drawn in these lines is correct. 


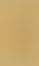

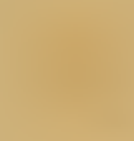




\section{Plate 4}

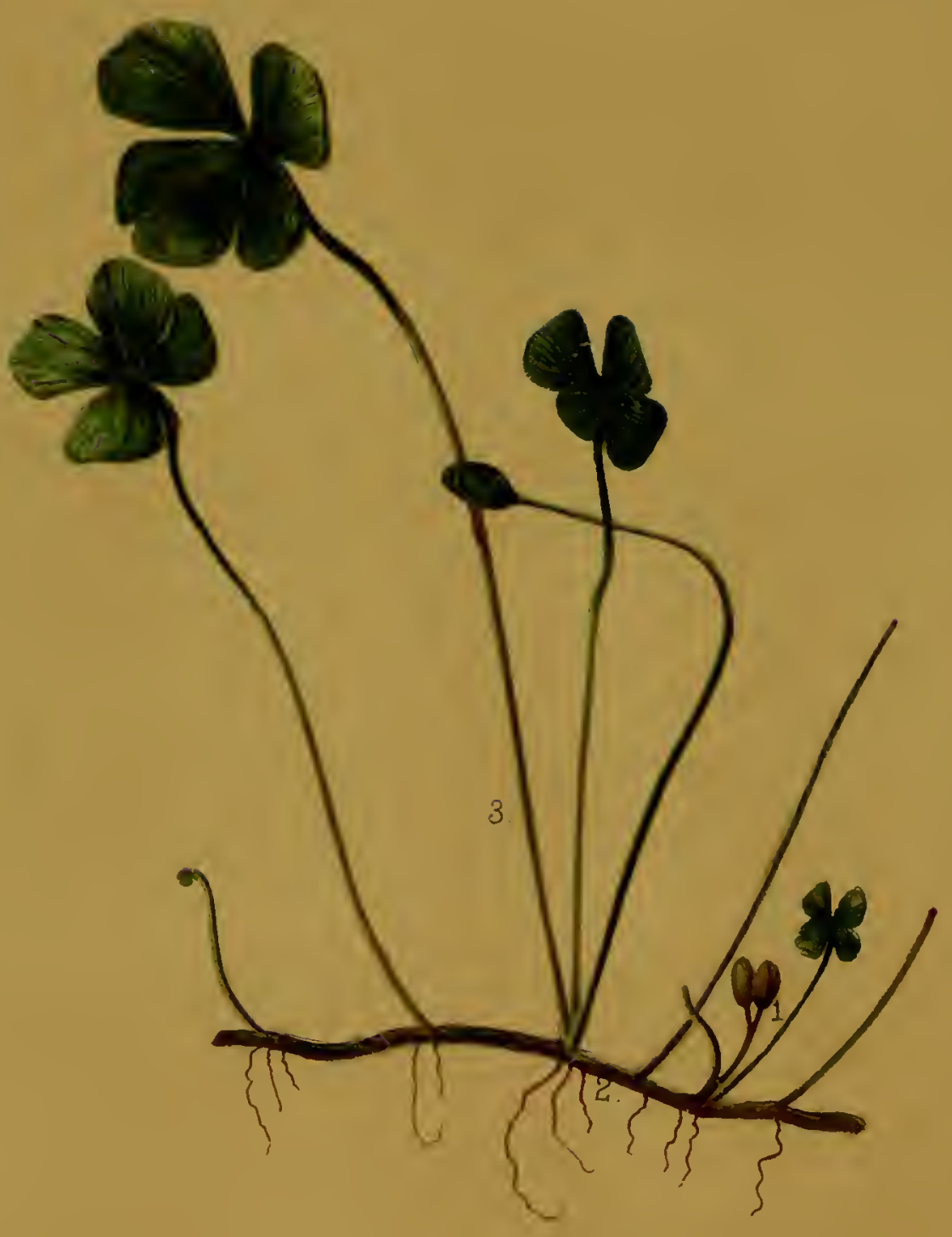




\title{
MARSILIA QUADRIFOLIA.
}

\author{
FOUR-LEAVED MARSIIIA.
}

NATURAL ORIER, MARSILIACE.

\begin{abstract}
MARSILII QUADRIFoLIA, Linnaxus. - Leaflets brondly obovate-cuneate, glabrous ; sporocarps usually two or three on a short pecluncle from near the lase of the petioles, pedicelled, glalsrous, or somewhat hairy. (Gray's Alunul of the Betuny of the' Northern L'nitud Stutes. Sce also Wood's Class-Book of Botuny.)
\end{abstract}

15. H IS genus, which has becn long known to botanists, is 13. gencrally written Marsilca, but Dr. Asa Gray remarks in his "MIanual" that it was named in honor of Aloysius Marsili, an early Italian naturalist, and therefore should be written Marsilia. It is probably one of the most interesting genera that we could introduce to American readers, for although some species are more or less to be found all over the world, it is yet extremely rare that American botanists get the opportunity of cxamining any of them. The present species, Marsilia quadrifolia, has only been found in this country during recent years; and for some time only a single locality, at Bantam Lake, near Litchfield, Connecticut, where it was discovered by Dr. T. F. Allen, was known to produce it. Indeed, it is still doubtful whether the species found in the other localities since recorded is really the one of which we now treat; and if so, whether it is indigenous therein. It was found in Fresh Pond, near Cambridge, Mass.; but Dr. Gray cxplains in the "Bulletin of the Torrey Botanical Club," that although so well established there, it is known to have been first introduced from the Connecticut station, and it may be so in some other places. Prof. Wood, in the cdition of his "Class-Book" for I $S_{74}$, describes it, on the strength of a specimen sent him by Dr. Hale, from Louisiana, 
but hints that it probably came from the other side of the Mississippi, which is not covered by his work. It seems, from the description, to be truly the Marsilia quadrifolia. In the "Bulletin of the Torrey Botanical Club" for i $S_{72}, \mathrm{Dr}$. J. Ball records it as having been found at Dallas, in Texas, in July of that year; but in a subsequent notice doubt is thrown on its existence in Texas, or indeed anywhere but in the one locality at Bantam Lake. It is thought the plants found belong to some other species, perhaps Marsilia vestita; but as the descriptions of these two very different species are both given in Prof. Wood's work, it seems probable that the existence of Marsitia quadrifolia in the Southwest may be confirmed.

The great rarity of the Marsilia quadrifolia in the United States has given food for speculation as to its conditions of existence here. It is found native in France, Germany, Siberia, and other parts of Asia, and it seems strange that it should be found indigenous with certainty only in this one locality in our own country. It is of course more than likely that it will yet be found in other places, but it is surely quite scarce enough to favor the question, raised a few years since by Dr. Gray in "Silliman's Journal": "Is its rarity a sign that it belongs to a very old family about becoming extinct, or is it one of the newer introductions of Nature, which has not yet had time to spread here to any great cxtent?" Geology, and indeed even many facts of modern history, show that numberless forms of plants have become extinct. With this process of extinction going on, the number of species would rapidly diminish, unless others came into existence to supply their places, and yet it is believed that there are quite as many species in existence now as there were at any period in geological history. When we speak of old families of plants dying out, it does not of necessity mean the oldest created forms, for especially among cryptogams, of which our genus is a part, there are some now in existence apparently similar to those found in the earliest fossil remains. It is the same evidently among plants as among races of animals, 
or even men. Some families will endure for a thousand years, while in the case of others a few hundred years are sufficient for their rise, growth, and final decay. Our present species would hardly seem to be one that is on the decline; as, if it were, it would probably not thrive and spread so freely in the Cambridge location, already noticed.

The natural order, Marsiliacce, which takes its name from this genus, was styled Hydroptcridcs, or Water Ferns, by Willdenow, and this is the name adopted by Dr. Gray in his "Manual of Botany." Lindley, on the contrary, who in all cases endeavors to denominate the order by the name of some one genus embraced by it, adopts the designation employed here, which was given to the order by R. Brown in the same year in which Willdenow named it Hydropterides; but in these matters priority does not tell, as it does in the case of a genus or species, since the system to be followed by an author is a matter of individual judgment. In the natural arrangement, the Marsiliacce are placed nearer to the Lycopodiacce than to any other cryptogamic division. One of the genera, indeed, that of Isoctes, has so much the character of both, that, while many authors include it in Marsiliacca, others place it in Lycopodiacec. The chief differences between Marsiliacce and Lycopodiacca, as defined by Lindley, is that, while the latter have their sporecases one to three celled, and their reproductive bodies similar, the plants of the former have their sporc-cases many celled, and reproductive bodies dissimilar. These spore-cases, with their contents, are matters of great interest to vegetable biologists, some of whom, notably Braun, Esprit Fabre, Hanstein, and others, have distinguished thenselves by the time and research bestowed on the study of these plants. The best account of them is, perhaps, found in Sachs' "Text Book of Botany," although that given in Lindley's "Vegetable Kingdom," chiefly from Esprit Fabre, vill be found very concise. It appears from these authors that the sporocarps (Fig. 1) or pepper-like capsules (from which the name of "Pepperwort" 
is probably derived) are formed by the rolling-up of leaves, and that these leaves are little more than the involucres, or perhaps bud scales, which we find in ordinary flowering plants. Morphologically, these sporocarps, with their pedicels or stalks, are probably arrested rhizomes; for as the sporocarps develop, a mucilaginous cord (equivalent to a stem or rhizome) is evolved, and along it numerous oblong plates (equivalent to metamorphosed leaves) which bear the spores or reproductive bodies on each side of their surface. These reproductive bodies are of two kinds,- the macrospores, or "larger" spores, being the analogues of pistils, or ovules; and the microspores, or "smaller" spores, which correspond to the anthers, or stamens, in flowering plants. The whole process of fertilization then goes on precisely the same as in the plants which we distinctively call "flowering." From this plant, therefore, we can learn the valuable lesson that what appears to be the fruit in these lower cryptogams is really only a flower bud, analogous to the buds in phrnogamous plants. The real flowers, with their separate sexual organs, develop subsequently, as in phænogams, and, morphologically speaking, are little removed from hermaphrodite, or at the best monœcious plants.

In Marsilia quadrifolia, the specific name quadrifolia is, of course, derived from the four-cleft leaf-blade. These blades float on, or are pushed above, the surface of the water in which the plant grows, and have much the appearance of an Oxalis, and like the Oxalis, close their divisions at nightfall. In Oxalis, we have noted that very bright light acts like the absence of light in causing the leaflets to close. and it may be the same with this plant.

The specincn from which our drawing was made grew at Cambridge, and we are indebted for it to the kindness of Mr. Jackson Dawson, of the Arnold Arboretum, Boston.

Explasatus of The PLate- - I. Sporocarps, with their pelicel pushing from near the base of a lenf-stalk. _ 2. Khizome as it creeps over the mucl. - 3. 1'ctiolc, with blade, forming a perfect leaf or frond. 



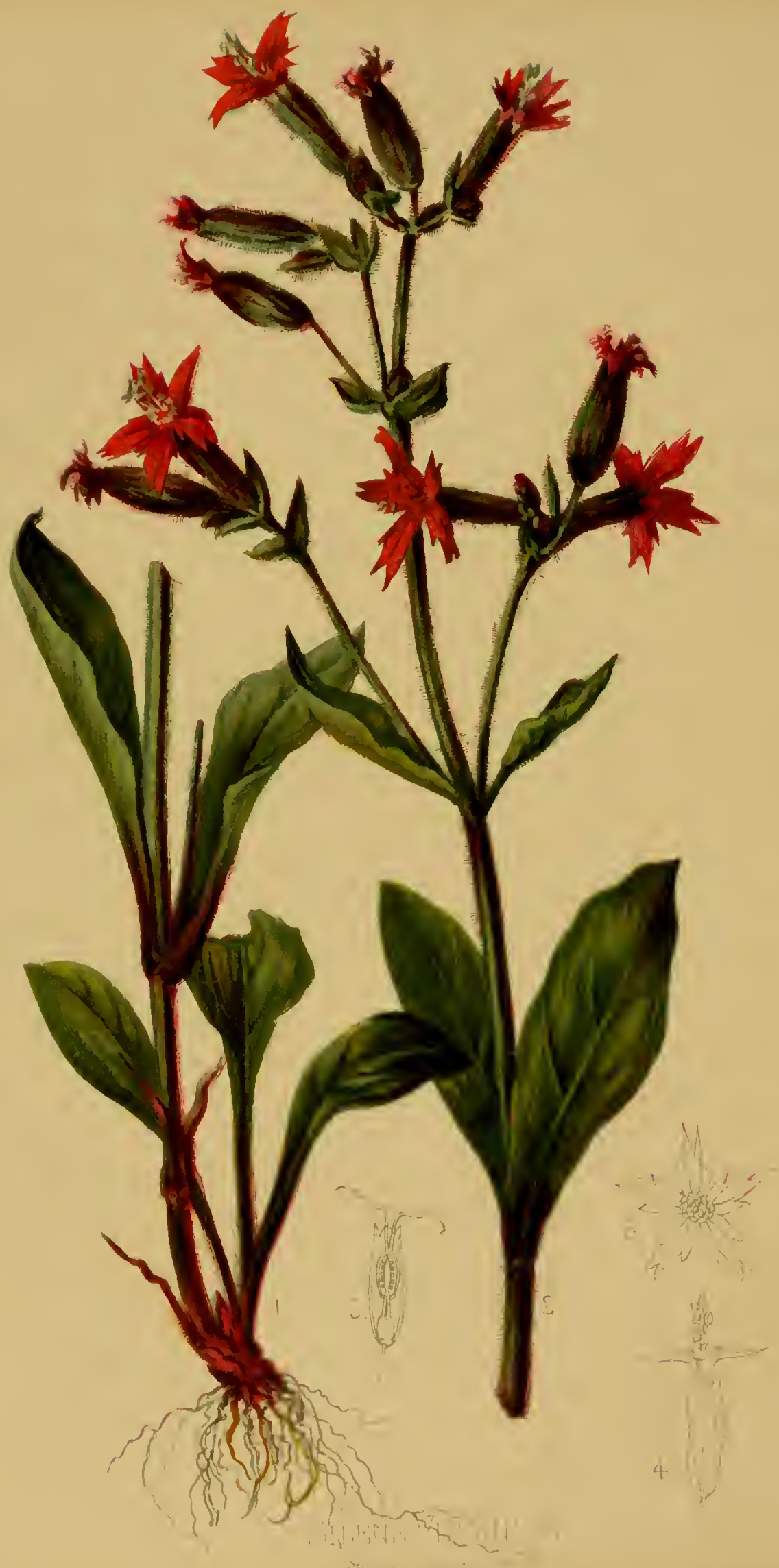




\title{
SILENE VIRGINICA.
}

\author{
VIRGINIAN CATCHFLY. \\ NATURAL ORDER, CARIOH'IVLLACEAE.
}

Silene Virginica, Limmeus. - Clammy-pubescent; learcs abruptly pointed, the lowest ones clusterecl, spatulate-olovatc, on fringed petioles, the upper small, rcmote, lanceolate, scssile; cymes looscly few-flowcred; calyx tubular-club-shaped, ollong and nodding in fruit; petals crimson, lanccolate, two-cleft. Stems onc to two fect high. Flowers one inch wide. (Chapman's Fion of tic Souturn L'nitut Statcs. Scc also Gray's Murnut of the Botuny of the Northern ('nitcil States, and Wood's Class-Book of Bioluny.)

E. HE genus Silene furnishes us with an interesting col13. lection of plants, many of which are commonly known as "Catchfiles." The home of these plants is in the cool or temperate parts of the world, and quite a number of them are natives of the United States, where they are about equally divided between the Atlantic and Pacific slopes of the continent.

The name Silene is an ancient one, and Linnaus simply adopted it when he constructed his system of botany. Of the several attcmpts made to explain it, we shall mention only one, as it is quite suggestive in connection with the English name Catchifly. According to the opinion of Dr. Asa Gray and other American botanists, Silcne is derived from the Greek sialon, saliva, and this designation was chosen because many of the species have a viscid exudation on the stems and calyx. To this exudation the common name, Catchfly; is also due. In the quaint language of Gerarde, one of the earliest known writcrs on English gardening: "If you touch [the plant] or take [it] on your fingers, the viscousness is such that your fingers will stick and cleave together, as if you had touched bird lime. If 
flies also do light upon it, they will be so entangled therewith that they eannot fly away, so that in some hot days you may see many flies caught thereby, from whence came the name Catchfly, or Limewort." Our Virginiain Catchfly, however, does not trouble the flies much, as it is considerably less sticky than those species which gave rise to the name. For this reason, probably, Catchfly is only given as a secondary designation by Dr. Gray and others, while Fire-Pink, by which name the plant is also popularly known, is awarded the first rank. But still it seems to us that the name "Virginian Catchfly" ought to be retained, as it brings our plant into eloser association with the rest of the family.

The specific appellation "Virginian" might also be objected to as inappropriate, and might perhaps mislead, if these botanical designations were looked upon as anything more than mere names. Our plant, like so many other plants, was first made known in Europe through the efforts of John Clayton, and it was called "Virginian," because Clayton lived and collected in Virginia. It is very natural, therefore, that this specific designation should have been retained, even after Plukenet's name, Lychnis viscosa Virginiana, had been dropped. Virginia, however, instead of being the geographical centre of the home of our species, is almost its southern boundary. According to Dr. Chapman, the plant is only found in the upper districts of the territory covered by his "Flora"; and Dr. Porcher notes it as occurring near Charleston, South Carolina, which is probably its extreme southern limit, although Prof. Wood cxtends its territory to Georgia. The writer of this has collected it in some abundance in Delaware; but north of that State its course is rather westward, for it is found only very sparingly in New Jersey, and scems to be entirely wanting in Eastern New York, as Dr. Gray takes IVestern New York as its starting-point. There is no evidence of its being found in Pennsylvania. In Ohio, Kentucky, and Southern Michigan, it appears to be general, but in Wisconsin it becomes rare, and in Iowa it is not 
seen at all. Dr. John Mĩ. Coulter reports it in Indiana; Prof. Aughey mentions it as growing ia Nebraska; and Mr. G. D. Butler has found it ia Arkansas, which is probably its extreme southwesterly limit. It is not, however, recorded in any Kansas collections, nor have we ever heard of its being found in Illinois or Missouri. It is very evident, from this statement of geographical distribution, that Virginia can lay but small claim to the special honor of being considered the home par cxcellence of the Silene Iirginica.

The poets and floral emblematists have endeavored to associate the idea of remorseless fate with the Catchfly, in consequence, probably, of the insect-trapping propensities of these plants. The unfortunate insect thus caught would certainly have good cause to exclaim with its Shakespearian companion in misfortune:-

"Yet who could have suspected an ambush Where I was taken? . . . .

All unavoidable is the doom of destiny."

The idea of remorseless cruelty, however, is much more applicable here than that of remorseless fate; and the elder Dr. Darwin seems to have held the same view, if we may judge from the well-known and often-quoted lines in his "Botanical Garden ":-

"The fell Siline and her sisters fair,

Skilled in destruction, spread the viscous snare."

No fitter type of cruelty certainly could be found than a plant which exercises its "skill in destruction," for the mere pleasure of killing; and this does indeed scem to be the case with the Catchfly, for it is not proved (although it has been suspected) that the plant needs the insects which it entraps for food, as does the Drosera and the other plants known specially as insectivorous plants. All this, however, is only a chapter in the family history of the genus, and has but little direct application 
to our present species, which is free from the Neronian propensities of some of its relatives.

In the study of the artistic handiwork of Nature, the Virginian Catchfly affords us a good lesson. The poet Thompson asks :-

\section{"But who can paint}

Like Nature? Can imagination boast,

Amid its gay creation, hues like hers?

- Or can it mix them with that matchless skill,

And lose them in each other, as appears

In every bud that blows ?"

In this case, however, we may perhaps be pardoned for criticising Nature. Our artist has faithfully copied her, but if he had followed his imagination instead, the heavy mass of leaves would no doubt have been crowned by a much greater profusion of scarlet petals. The comparative paucity of color in our plant is increased still further by the thick and heavy calyx, and above all by the shape of the lobes of the corolla, which are finely cut into slender threads, thus not only breaking up the masses of color which the flowers would otherwise form, but also increasing the general heaviness of the plant by contrast with their extreme tenuity. Jf, however, we may dare to criticise the artistic skill of Nature as regards the composition of the whole plant, we can at least offer her our congratulations on her success in the formation of each single flower, as shown in the ground plan, Fig. 3. Here there is truly a beautiful harmony of proportions in the stellate form; and the little fringy margins, which produce so unsatisfactory an effect when we look at the inflorescence in its totality, are just what is required here to give perfection to the whole. The side view of the flower (Fig. 4) is also a very pretty model of artistic beauty.

Explanation of TH: PLitf. - 1. Lower portion of a flower-stem, with fibres and clustered ruot-leaves. - 2. Upper portion of fluwer-stem, with complete inflorescencc. - 3. Fuil. face view of a flowcr. - 4. Sille vicw of a flower. - 5. Longitudinal scction of cal $x$ and ovary, showing the gynophore or stalk on which the pistil is raised, and the arrangement of the ovaries on the central placenta. 

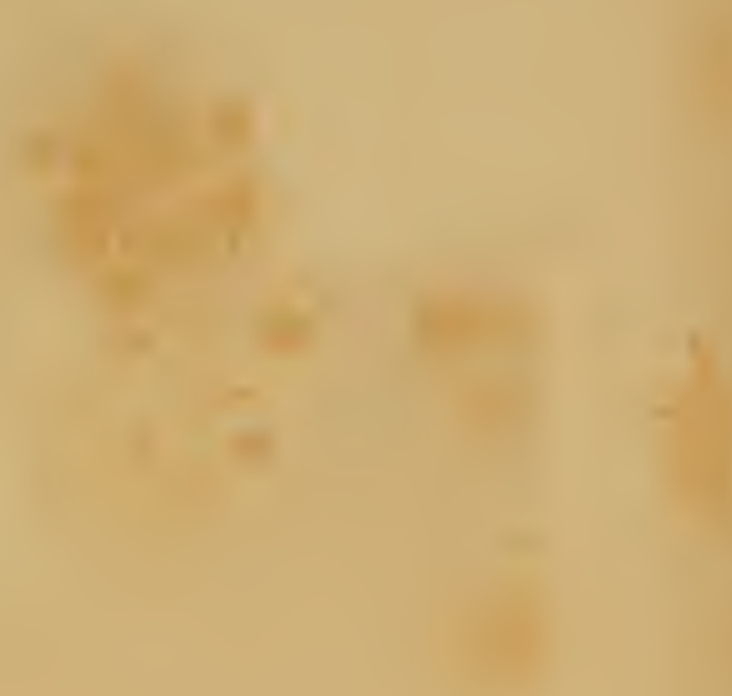

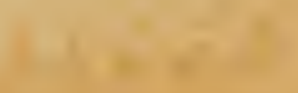

$=$

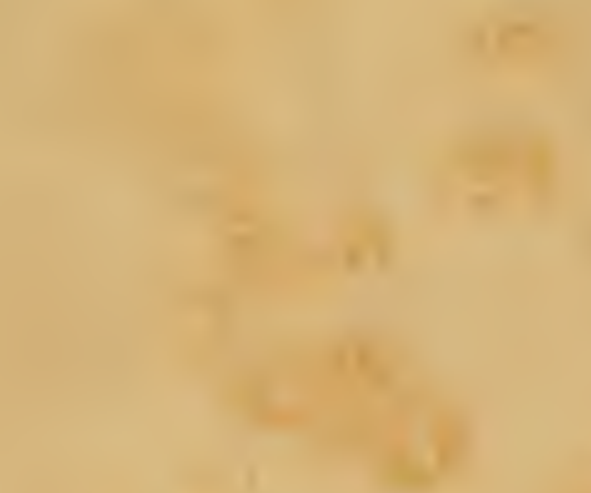




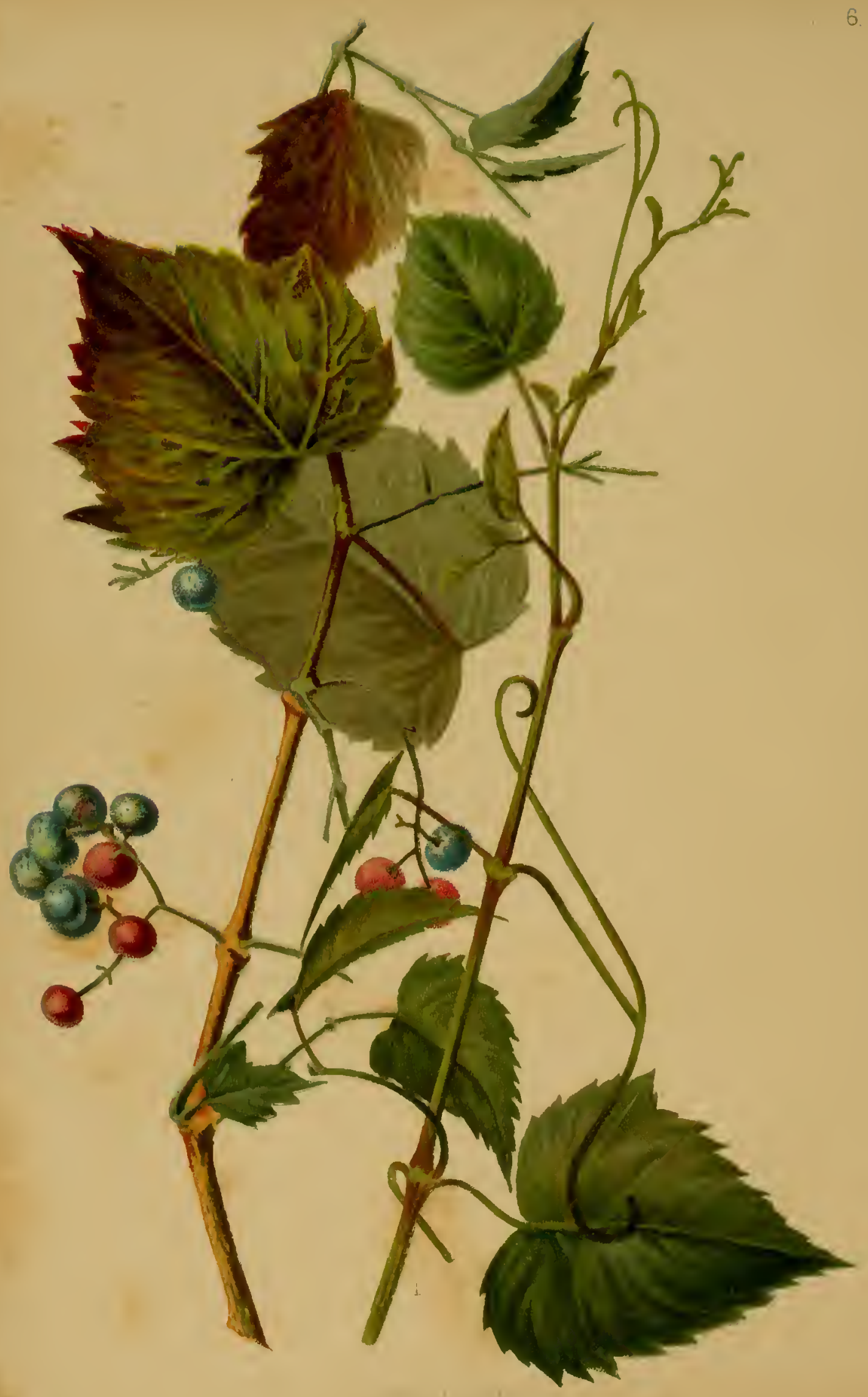




\title{
VITIS INDIVISA.
}

\author{
ENTIRE-I,EAVED IVY-GRAPE.
}

NATURAL ORDER, VITACEA.

\begin{abstract}
VITIS INDIVISA, Willdenow. - Leaves simple, undivided, ovate, truncate, or cordate at the base, acuminate, toothed-serrate, pubescent; peduncles forking; petals and stamens five; style slender; disk cup-shaped; berry one to three-seeded. (Chapman's Flora of the Southern Unted Statis. See also Wood's Class-Book of Botuny, and Gray's. Wranual of the Botruy of the Northern Linited State's.)
\end{abstract}

HE plant which our plate illustrates belongs to the great order of grape-vines, and we need scarcely add that this order is one of the most famous, as regards its connection with the history of man. Homer frequently mentions wine, and the scriptural account of Noah, according to which the planting of a vineyard was one of the first occupations of the patriarch after the deluge had subsided, shows that the original wild grape had even then lost its harsh character by cultivation, and that the fruit of its improved descendants was among the most highly valued products of horticulture. The botanical name of the grape-vine, Vitis, is also of great antiquity, and its original meaning was lost long ago, although some philologists are of opinion that it refers to the rope-like stems of the plant, which might be used for binding, or for basket-making. This opinion receives some support from the fact that a number of words, having a similar meaning, and still in use in various modern languages, have evidently been derived from a similar root.

Our Vitis indivisa, however, can hardly claim to be connected with the ancient history of the genus, as it has been admitted to membership in the family only within a comparatively recent time. There is little, indeed, in the leaves, and still less in the 
fruit of the species to suggest any close relationship to the grape-vine, and the earlier botanists, therefore, classed it in another genus, called Cissius. This genus, however, has been abolished by some authors, but the name Cissus is still retained by them, as the appellation of that section of Vitis to which our plant belongs. Cissus is from a Greek word, signifying ivy, and following the lead of the botanists, we may therefore give the name of "Ivy-Grapes" to all the species which are united in the same section with Vitis indivisa.

Under the Linnæan system, when the number of stamens decided the class, the species of the section Cissus were placed in the fourth class, Tetrandria, because the blossoms generally have only four stamens, while those which belong to the other section, known as Titis proper, went into the class Pentandria, as having five stamens. This wide separation of such closely allied plants shows the arbitrary nature of the so-called sexual system. At present, the number of stamens is regarded as of little moment in systematic classification in those cases in which all other characters exhibit a close relationship. The chief mark of distinction between the present sections of Vitis is derived from the petals. In Vitis proper the petals are united at the apex, and the whole corolla is pushed off in one piece by the swelling ovaries, as the flowers fade. In Cissus, the petals are not united, and expand in flowering, so that they fall separately. There is also more of a tendency in the inflorescence of the species belonging to Cissus to assume a divaricate or forking character, while in Vitis proper, comprising the true grapes, the flowers are arranged in a sort of racemose panicle, or bunch.

Vitis indivisa takes its specific name from the fact that its leaves are entire, having only coarse, sharp teeth along their edges, while other American species have lobed, or variously divided leaves. We may, therefore, with propriety call our species the "Entire-Leaved Ivy-Grape." It is a very remarkable fact that in Asia there is a species known as $I$. heterophylla, which, 
both in the earlier and in the later clevelopment of its yearly round of plant-life, is so like $T$. indivisa that it can be distinguished from it only with clifficulty, while in the intermediate stages the difference between the two is obvious enough. In the carly stages of its growth from the seed, the Asiatic species has entire leaves, but as the leaves develop they divide into lobes, which of course changes the character of the plant. Late in summer, however, as the fruit begins to ripen, the distinction is again somewhat obliterated, as the character of the berries and the arrangement of the clusters is very similar in both species. In view of these facts, it will be interesting to inquire whether the two plants have had the same origin; and if this question should be answered in the affirmative, to ascertain the law which compelled the $I$ : hetcrophylla of Asia to assume a character so different from that of its sister species in the United States. We may add that in China the $I$. hotcrophylla is said to vary in the lobing of its leaves, according to its place of growth in the north or in the south of the empire.

The gradual change in the color of the ripening fruit of our species is well worth observing. Dr. Chapman says the berries are small and black, while Prof. Nood informs his readers that they are small and pale red. The truth of the matter is that the berries are at first green, then become red, and finally, after having passed through a beautifully mottled blue, turn quite black when ripe. The red and the blue stages are both shown on our plate.

The Entire-Leaved Ivy-Grape does not seem to have a very wide geographical range. Dr. Chapman, in his "Flora of the Southern United States," says it is found on "banks of rivers, Florida to North Carolina, and westward"; but Dr. Curtis does not inclucle it in his "Catalogue of the Woody Plants of North Carolina," and it is very probably not common east of the Alleghanies beyond the North Carolina line. Dr. Gray, whose "Manual" includes only the Northern States, limits it within this area to "river banks, West Virginia, Ohio, and southward," 
and Prof. IVood says "swamps, Southern States to St. Louis," while Torrey and Gray, in the "Flora of North America," locate the plant in the "Southern States west to Louisiana and Arkansas." We may add that in Ohio it is probably confined to the southern part of the State. A writer in the "Botanical Gazette" reports having found it in Eastern Indiana, and the writer of this has bimself collected it in Kentucky, Tennessee, and Northern Texas. In fact the plant from which our drawing was made was raised from cuttings brought from the state last named.

In its native places the Vitis indivisa is a strong-growing vine, completely covering the low trees over which it climbs, and forming picturesque, hollow masses of foliage, resembling arbors. In the fall of the year the leaves turn to a yellowish or orange brown, which with the red, blue, and black berries form a very attractive combination of colors. In the hands of the skilful landscape gardener our plant ought to be a most valuable element. Like most of the species of the grape family, it can be raised easily from cuttings as well as from seeds.

To the close observer the grape-vines offer many points of interest. The nodes, or joints in the stem, usually produce tendrils at certain regularly recurring intervals, or rather each node without tendrils is preceded and followed by a fixed number of nodes with tendrils. Mr. Darwin has shown that these tendrils are in continuous motion, sometimes for several days, until they have found something to cling to, and the writer of this has demonstrated that this motion, if it remains unsatisfied, has a most exhaustive effect on the health and vigor of the plant. There are, indeed, very few plants that will afford so great a variety of interesting themes for study as the various species of the grape.

Explanation of the PLitr. - I. A branch, showing the late fall-growth. - 2. Branch of early growth, bearing fruit and mature leaves. 



\title{
IPOMCEA LEPTOPHYLLA.
}

\author{
COLORADO MAN-ROOT.
}

NATURAT, ORINER, CONV(IIYUIACLA.

I POWEA JETTOPINLL, Torrey. - Two to three fect high, much branched from the base; branches long, spreading, and prostrate, angular, glalrous; leaves linear and lanceolatelinear, attenuated at both encls, strongly veined, glabrous, mucronate-apiculate, shurt-petioled; pecluncles one to three-flowered, half to one and a half inches in length; sepals appressed, broadly avate, very obtuse, with a minute mucro, five lines long; corolla futsnel form, two to two and a late inches long, purple; stamens inserted near the hase, filaments villous at the base, anthers oblong-linear, large; style as long as the stamens, stigma two-lobed, lobes capitate; ovary two-celled, with two ovules in each cell. (Porter's Synepsis of the Flora of Colorado.)

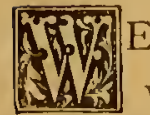

E have made it our principle, whenever the plants of which we treat are described in several works, to refer our readers to the authority which is likely to be most accessible to them. For this reason, we have taken the description at the head of this chapter from Prof. Porter's "Synopsis of the Flora of Colorado," although it was first published by Dr. Torrey, in his account of the plants collected by Gen. (then Col.) Fremont, on his first cxpedition across the continent in 184 . Wc have, however, deviated from Prof. Porter's orthography of the generic name, Ipomca, and have returned to Dr. Torrey's spelling, Ipomoca, because this is generally in use among the botanical authors of our time.

Our plant was also found by Lieut. Emory's party in July, I 846 , and a representation of it was given in the report on the botany of Emory's cxpedition by Dr. Torrey. Subsequent collectors have found it in various localitics in Western Kansas and Eastern Colorado, in the dry, sandy, and barren region watered by the Platte and Arkansas Rivers, and as far south as Northern 
Texas. In Emory's report, Dr. Torrey says that it was gathered on the upper part of the Arkansas, and the headwaters of the Canadian River.

"The stems," continues the same writer in the work just quoted, "are often erect, about two feet high, and of a bushy appearance. From the appearance of the specimens, I should suppose the plant was a perennial, but according to Dr. James, it is an annual." Dr. Porter also accepts the statement made by Dr. James, although he qualifies it somewhat by marking the plant "annual?" All these authorities, however, are mistaken, for the Ipomaca leptophylla is a perennial. Yet the mistake is quite explainable, as to the hurried traveller the plant may easily appear as an annual. The writer collected it in 187 I on the line of the Arkansas River, and on drawing it out he found it to come up much the same as an annual would. But it is singular that Emory's own account should have been overlooked, as in it the perennial character of the plant is clearly made out, and we can only explain this oversight by supposing that Emory's description was not in Torrey's hands when he drew up the account of the botanical collections. Emory, in his "Notes of a Military Reconnoissance, etc.," Washington, I 848 , page 1 3 , writes as follows: "The soil of the plains is a granitic sand, intermixed with the exuviæe of animals and vegetable matter, supporting a scanty vegetation. The eye wanders in vain over these immense wastes in search of trees. Not one is to be seen. The principal growth is the buffalo grass, caeti in endless variety, and very rarely that wonderful plant, the Iponcea lcptophylla, called by the hunter. Man-Root, from the similarity of its root in size and shape to the body of a man. It is esculent, and serves to sustain human life in some of the many vicissitudes of hunger and privation to which men who roam the prairies as an oceupation are subjected." There is not, indeed, a positive statement in this passage that our plant is a perennial, but with our knowledge of Ipomaxa pandurata, or even of the common Sweet Potato, which belongs to the same family, and 
considering besides that few annuals have edible roots, the inference that it is a perennial is perfectly legitimate.

The account of the immense size of the root given by the hunters to Licut. Emory is not cxaggerated. Dr. Lamborn handed to the writer a communication from a correspondent in Colorado who had engaged to have one of the roots dug for the Centennial Exposition at Philadelphia, and according to this communication, it took two men, working with picks and crow-bar, a full day to do the job.

The immense root of our plant, which descends six or seven feet beneath the surface of the ground, may be regarded as a provision of Nature for enabling it to live in a region where rain seldom falls, and which seems only to be fitted for cacti and other similar succulent plants, with a comparatively small surface. A leafy plant, like the Ipomae leptophylla, which through its great extent of surface must necessarily lose much moisture by evaporation, could not live in such a region without some contrivance of this lind. The root is really a trunk beneath the ground, which instead of losing moisture, as it would if it were above ground, absorbs it, and stores it up in its huge body, so that the plant may continually draw on it for its supply during the growing season without fear of failure, no matter how long the drought may last.

The first sight of a flower of the rare beauty of our Ipomoea is a great and pleasurable surprise to the traveller, when meeting with it, as did the writer of this, in such a desert land as is frequently found on our western plains, and the incident involuntarily brought to mind the touching lines by Mrs. Hemans, which were suggested to her by Mungo Park's meeting with a beautiful flower when in great distress in the African desert:-

"Why art thou thus in thy beauty cast,

O lonely, loneliest flower,

Where the sound of song has never passed

From human hearth or bower? 
His glance was caught by the desert's flower,

The precious boon of heaven,

And sudden hope, like a vernal shower,

To his fainting heart was given.

For the bright flower spoke of One above,

Of the Presence felt to brood,

With a spirit of pervading love,

O'er the wildest solitude.

Oh! the seed was thrown these wastes among

In a bless'd and gracious hour,

For the lorn one rose, in heart made strong

By the lonely, loneliest flower."

Ipomaca is from the Greek, and signifies "like to a bindweed." The Bindweeds proper are the Convolvali, so called from the twining habits of many of the species. The Man-Root is related to the Convolyulus, and this relationship Linnæeus, who first gave the name to the genus, clesired to express. The difference between the two genera is shown in several characteristics, one of the most prominent being the capitate stigma (Fig. 3) in Ipomoca, while Convolvulus has a stigma with two linear lobes. But the two genera are so nearly alike that many species of Convolvulus have been called Ipomoca, and many a true Ipomoca has been regarded as a Convolvulus.

As the Man-Root has only been known a short time, and as until recently the opportunities for getting seed were limited, it is only within the last year or two that we have been able to test its capacity for garden culture. It seems likely to do very well, however, and is doing nicely in the writer's garden. Our drawing, by the kind permission of Prof. C. S. Sargent, was made from a plant growing in the Cambridge Botanic Garden. The flowers are larger and the general vigor is greater in this specimen than in any of the plants which we saw in their wild location.

Explanation of tie PLite. - I. Flowering branch, showing flowers and leaves. 2. Flower-stalk and calyx after flowering. - 3. l'istil, showing capitate stigma (from Emory's Report). 



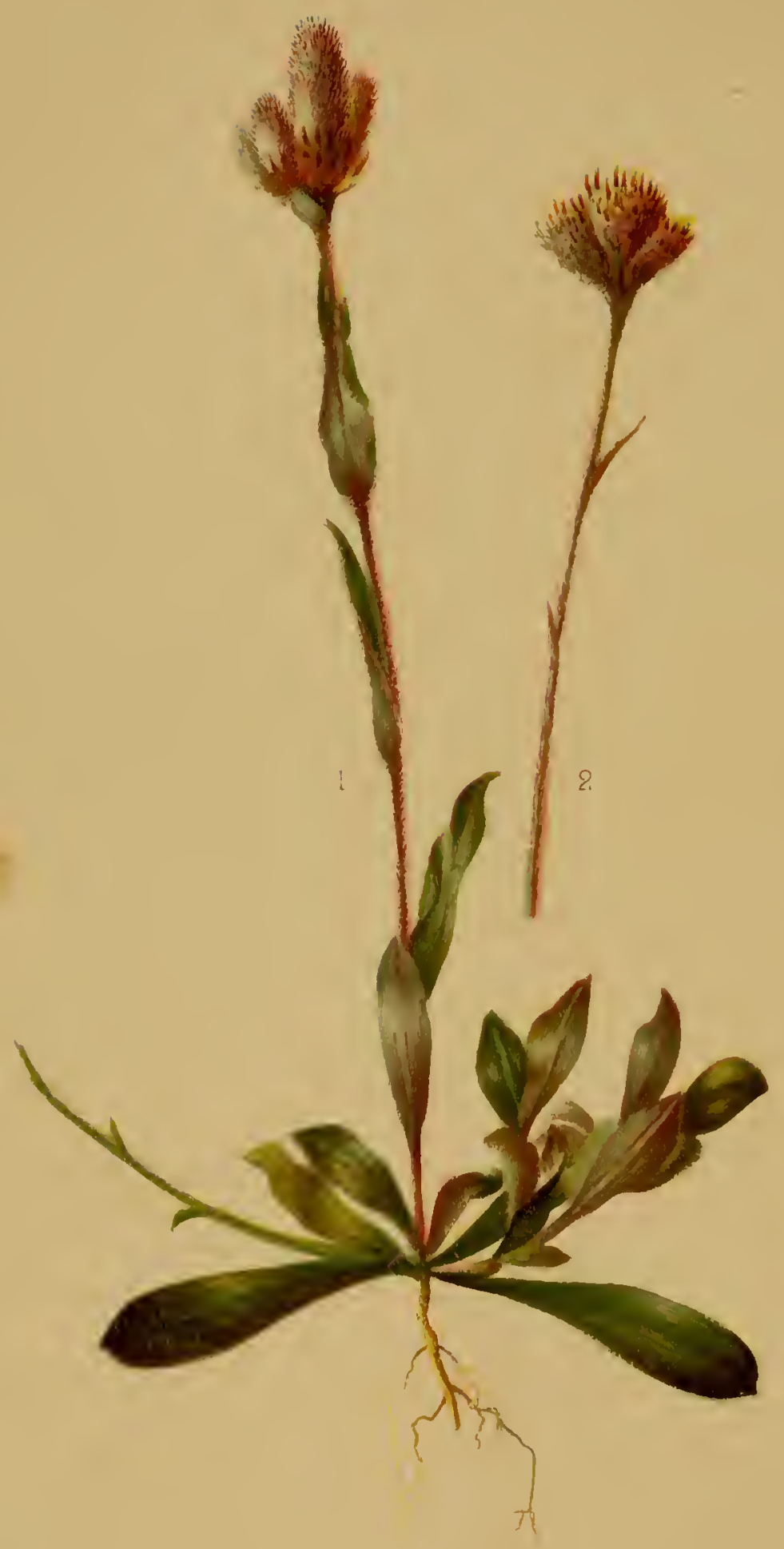

ANTENNARIA PLANTAGINIFOLIA 


\title{
ANTENNARIA PLANTAGINIFOLIA.
}

\author{
MOUSE-EAR EVERLASTING.
}

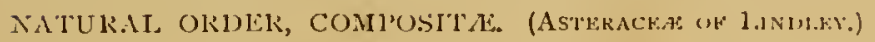

\begin{abstract}
Antennaria flantaginifolia, Hook. - Stem simple, with procumbent runners at base; radical leaves spatulate, or elliptic, and three-nerved; corymb clustered; involucral scales greenish. (Darlington's Floril Cestrica. Sice also Gray's Mlamual of the Botuny of the Northern United Statis and Wood's Class-Book of Botany.)
\end{abstract}

T70 N the early spring few flowers are hailed with more 速. pleasure than the Mouse-Ear Everlasting, or "Pussy's Foot" of the young folks. The plant is by no means handsome, in the ordinary acceptation of the word, but it comes at a season of the year when everything is welcome, and expectations are not very high-strung. In Pennsylvania it is generally in flower in April, and even on warm March days children often go out in to the woods and wild places in the hope of finding Pussy's Foot in bloom; and Mr. Brodhead, writing in the "American Naturalist" for I 569 , includes it in a list of ten plants which flower earliest of all in Cass County, Missouri.

In the article just referred to, there are also some very interesting figures, showing that the comparative earliness of different kinds of flowers is not regularly the same every year, and that a season which is favorable to one plant may not be as favorable to another. In the year I 864 , for instance, the White Dog's-Tooth Violet, Erythronium albidum, was in flower as early as the 29th of March, while our Mouse-Ear Everlasting did not open till the 27 th of April, or nearly a month later. The next year the Dog's-Tooth Violet did not open before the 2d of April, while our plant bloomed fully a week earlier than 
in the previous year, or on the igth of April, thus reducing the difference in time between the flowering periods of the two to little more than two weeks. But the most interesting observation was made in IS6S, when the Dog's-Tooth Violet was in bloom on the 2Sth of March, and the Everlasting on the Ist of April. IVe see from all this that, while in IS6+the difference in time between the two was nearly a month, it was only a few days in I 868 , and furthermore, that the opening day of the Dog's-Tooth Violet remained almost stationary (March 29, April 2, March 2S), while the Mouse-Ear Everlasting varied from the 27 th to the 1 st of April. The explanation of this curious fact is, no doubt, to be found in the occurrence of a few warm: days in March, which may make all the difference. As the Dog's-Tooth Violet and the Everlasting open shortly after one another, providing that the temperature remains stationary, it follows that the second must gain on the first if a few very warm days happen to succeed the opening day of the Violet, while the Everlasting must necessarily be retarded in case cold weather sets in. We may conclude, therefore, that the forwardness of any one season cannot be predicated upon the day of opening of the early-flowering plants. Such facts only show that there may have been a few warm days about the time of blooming.

Although, as already observed, our plant is not a particularly showy one, it is yet one of those which improve on acquaintance. It does not let us into its secrets all at once, but reserves some of them for future occasions. One of the most interesting features of the genus to which it belongs is that it is diøcious, or in other words, that the male flowers are on one plant and the female flowers on another, - an arrangement which is far from being common in the allied plants of the asteraceous or composite class. In the genus Gnaphalizm, for instance, to which our plant is nearly related, and with which it was, in fact, classed by the older botanists, the central flowers in each head are perfect or hermaphrodite, that is to say, contain both stamens and 
pistils, while the outer are female or pistillate. It was this strict separation of the sexes, in fact, which induced modern botanists to separate our plants from the Guaphalizms, and to set them up for themselres in the genus Antcnuaria. So striking is the peculiarity that Rafinesque suggested the name Disymanthus for the genus, a Greek compound, signifying "two (individuals) together," in allusion to the necessary co-operation of two individuals in the propagation of the kind. But the name did not prevail, as the genus had already been called Antcnnaria, and in botany the oldest name always takes precedence.

A very interesting fact in connection with the dicecious character of Antcnnaria plantaginifolia is recorded in the first volume of the "Bulletin of the Torrey Botanical Club," in an article apparently from the pen of the editor. Speaking of some flowers found in bloom at Bergen Neck, near New York, on the I 4 th of May, the writer of this article remarks that they were all staminate, or male, and expresses it as his belief that the pistillate, or female flowers must have been perfected several weeks before. It is true, no doubt, that in many plants the pistils seem to be perfected a day or two before the anthers burst, and this fact has been explained as implying an arrangement in favor of cross-fertilization. But the dicecious distribution of the flowers may also be regarded in the same light: and yet so great a difference in time between the appearance of the sexes, if confirmed and found to be general, would seem to negate all possibilities of fertilization. The author of the article in question is, therefore, perfectly correct when he says that the matter is worthy of further examination.

The immense amount of variation to be found in our species is another point of interest, and our knowledge of this tendency to vary is greatly assisted by the mode of growth of the plant. Being a perennial, and multiplying by means of little runners, one plant must necessarily produce quite a large number of individuals together in a patch, all of which have sprung from one seedling, and therefore have the tendency to perpetuate and 
develop its peculiarities. If we compare two single flowers, taken from different patches, it may be difficult, perhaps, to express their difference in words. But the multitude of little flowers seen crowded together in one patch imparts a very distinctive character to the whole, so that scarcely any two patches look alike.

The generic name of Antcunaria plantaginifolia is from the Greek, and refers to the shape of the bristles which form the pappus or down of the male flowers. (Fig. 2) These bristles thicken towards the upper end, looking like miniature clubs, and in this respect resemble the antonna or "feelers" of some insects. Hence the name. The specific appellation plantaginifolia is derived from our common weed, the plantain, or the "White Man's Footprint," as the Indians call it, because it seems to follow closely on civilization wherever this goes. The leaves of the plantain have a mid-vein or rib, and on each side of this other veins or ribs, which describe a section of an arc from the base to the apex. The winter leaves of our plant have three veins of a similar character, and generally resemble the plantain leaf in shape, so that the epithet "plantain-leaved" is quite appropriate.

IVe have seen that Antcnnaria used to be classed with Gnaphalium. The plants belonging to the latter genus are truly called "Everlasting," from the enduring character of the flowers of some of them, and very naturally the family name clung to our plant even after it had severed its former connection.

The different aspects of the male and female flowers strike the observer at once, and have been very well represented in the - plate by our artist, Fig. I being the female, and Fig. 2 the male.

The Mlouse-Ear Everlasting is common through all the Atlantic States on the lower lands, but it does not appear to have crossed the Mississippi to any great extent. Mr. Butler reports that it is sparingly found in Arkansas.

Explanation of the Plate. - 1. A plant with female flowers. - 2. Flower stalk with male flowers. 



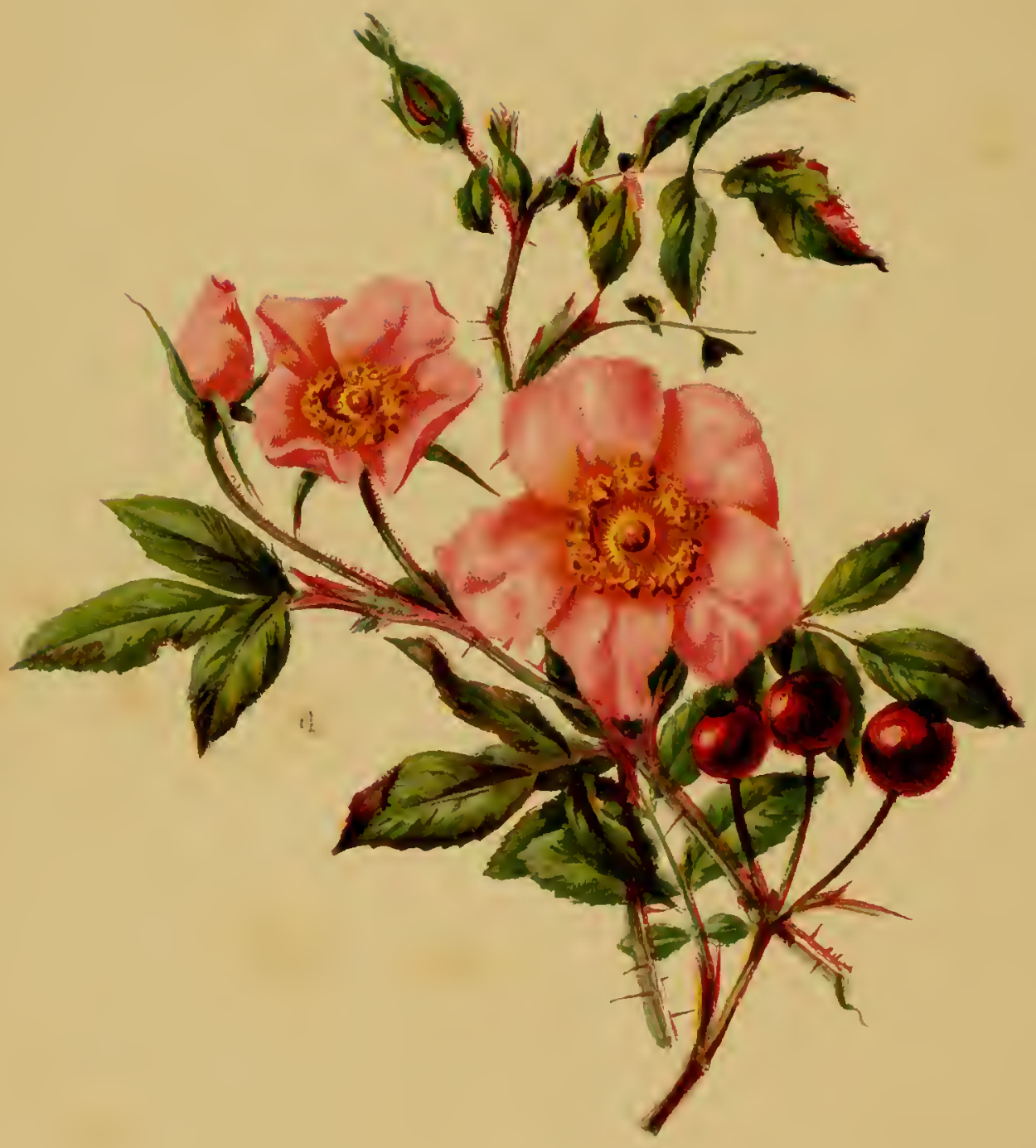




\section{ROSA LUCIDA.}

\section{DWARF WILD ROSE.}

NATURAL ORDER, ROSACEE.

Rosa LUCIDA, Ehrhart. - Stems one to two fect high, armed with unequal bristly prickles, which are mustly deciduous, the stouter persistent ones nearly straight, slender; leaflets five to nine, elliptical or ublong-lanceulate; shining above, sharply serrate ; stipules broad; peduncles one to three-flowered, and with the appendaged caly-lobes glandular-bristly; fruit depressed-globular, smooth when ripe. (Gray's Manuml of the Botany of the Nentherse United States. See also Chapman's Flon of the Sonthern United States, and Vood's ClassBook of Boturny.) opening lines of the so-called Homeric hymn in :onor of Demeter (Ceres), in which Persephone (Proserpina) is represented as gathering "roses and beautiful violets," besides other wild flowers; and thenceforward all the poets have vied with each other in extolling the charms of the acknowledged queen of the floral world. Some of the most delightful of the ancient legends connected with the Rose relate to its origin, which they account for in a variety of ways. Thus one of these legends informs us that Flora, being grieved at the loss of one of her favorite nymphs, implored Jupiter to change the dead body of her former companion to a living flower of surpassing beauty; and, her prayer having been granted, Apollo, Bacchus, Vertumnus, and Pomona gave to the new-born flower various attributes of their own perfection, while another account says that the Rose sprang from the tears of Venus, as she wandered about in search of her beloved Adonis. All the older nations have 
legends ascribing a fanciful origin to the Rose, and even the matter-of-fact Turks declare that our flower was born from the drops of perspiration which fell from the brow of Mahomet. So impressed, indeed, were the ancient poets with the superlative beauty of the Rose that they were not content with giving it an almost divine origin, but even considered it necessary to create Olympian messengers to watch over and care for it:-

"The sporting sylphs that course the air,

Unseen, on wings that twilight weaves, Around the opening rose repair,

And breathe sweet incense o'er its leaves."

The several legends alluded to in the preceding paragraph seem, however, to look upon the Rose as white, and various other fancies are therefore called in to account for the Red Rose. According to the Greek myth, it was the Red Rose which sprang from the drops of blood that flowed from the wounded feet of Venus, as she rushed through the woods in an agony of despair, in search of the dead body of Adonis. Thomas Moore, in his "Ballads," gives another version of the birth of the Red Rose:-

"They tell us that Love in his fairy bower

Had two blush roses of birth divine.

He sprinkled the one with a rainbow shower,

But bathed the other with mantling wine.

Soon did the buds

That drank of the floods

Distilled by the rainbow, decline and fade;

While those which the tide

Of ruby had dyed

All blushed into beauty, like thee, sweet maid !"

The different kinds of roses also owe their origin to supernatural agency, if the poets may be trusted. Thus Roscoe tells us that, - 
"As Venus wandered midst the Idalian bower, And watched the Loves and Graces round her play, She plucked a musk rose from its dew-bent spray; 'Ancl this,' she cried, 'shall be my favorite flower; For o'er its crimson leaflets I will shower

Dissolving sweets to steal the soul away!'”

The etymology of the generic name, Rosa, is not clear. The Greeks called the Rose rhodon, the Latins rosa, and it is generally supposed that the root of both these words signifies "red." Some thoughtful minds, however, have come to the conclusion that this derivation is not satisfactory, although to the mass of the people it will probably seem to be more than likely, for "red as a rose" is almost a proverbial cxpression. Dr. Prior remarks: "The Latin rosa appears to be a foreign word, introduced to replace a more ancient name for this shrub." Bauhin, a writer of the sixteenth century, credits Plutarch with the suggestion that the original name signified something which "emits an abundance of sweet odor," and if philology can show any reason for this suggestion, it will be a point worth considering.

Our present species, Rosa lucida, owes its specific name to the bright, shining green of the upper surface of its early leaves. In its botanical character it comes nearer to the Rosa Gallica, one of the great types of old-world roses, than perhaps any other American species. In fragrance it certainly cquals the best of the roses of the old world, and if it were to receive the care of the florist, it might also become their rival in many other respects. In its wild condition it does not show as much tendency to vary as some other species. In the number of petals and in the shade of color, there is much uniformity, while the greatest variation to be found in this plant is noticeable in the broadening or narrowing of the petals. In the form of the leaves, in the size and position of the prickles, and in the degrees of glandular hairiness, all of which are characters of some botanical importance, there is also more or less departure from uniformity; but the straight prickles, running at right angles with the stem, are so character- 
istic of this species that they will generally lead the student to a correct decision as to its identity, in spite of the variability of other characters. This peculiarity has been very well shown by our artist, who has carefully preserved the botanical characteristics of his original, while at the same time he has been admirably successful in reproducing the poetical spirit which pervades our flower.

It is now believed that there are but very few good species of roses, and that many forms which, even comparatively a short time ago, had names of their own, must be looked upon as mere varieties. This state of things has given rise to a great many synonyms and a good deal of attendant confusion, so that it is sometimes clifficult to tell what particular species an author may be alluding to; and it is also owing to the same cause that the geography of our present species has been somewhat obscured. Prof. Wood says it grows "in dry woods and thickets throughout the United States"; Dr. Chapman says, "Florida and Mississippi northward, mostly in dry soil, common "; and according to Dr. Gray, it is "common in dry soil or along the borders of swamps"; while Torrey and Gray's "Flora of North America" locates it "in dry places in the margins of swamps, Newfoundland, and New England States to Georgia." So far as we can ascertain, it is most common in the Seaboard States, and is rather abundant through Ohio and Michigan to Nebraska, in the western part of which state it gradually disappears. It has quite recently been found in Iowa, by Messrs. Coleman and Burgess, but only in very few locations, while in Kansas it has not yet been found at all. How far it extends south along the eastern shore of the Mississippi, it is scarcely possible to say, owing to the uncertainty in the application of synonyms. In Northern Texas it has recently been collected by Mr. Ruffner.

We have adopted the common name, "Dwarf IVild Rose," given by Dr. Gray, as it seems to be the most appropriate, although our flower is also known as the "Shining Rose," or simply as the "Wild Rose." 



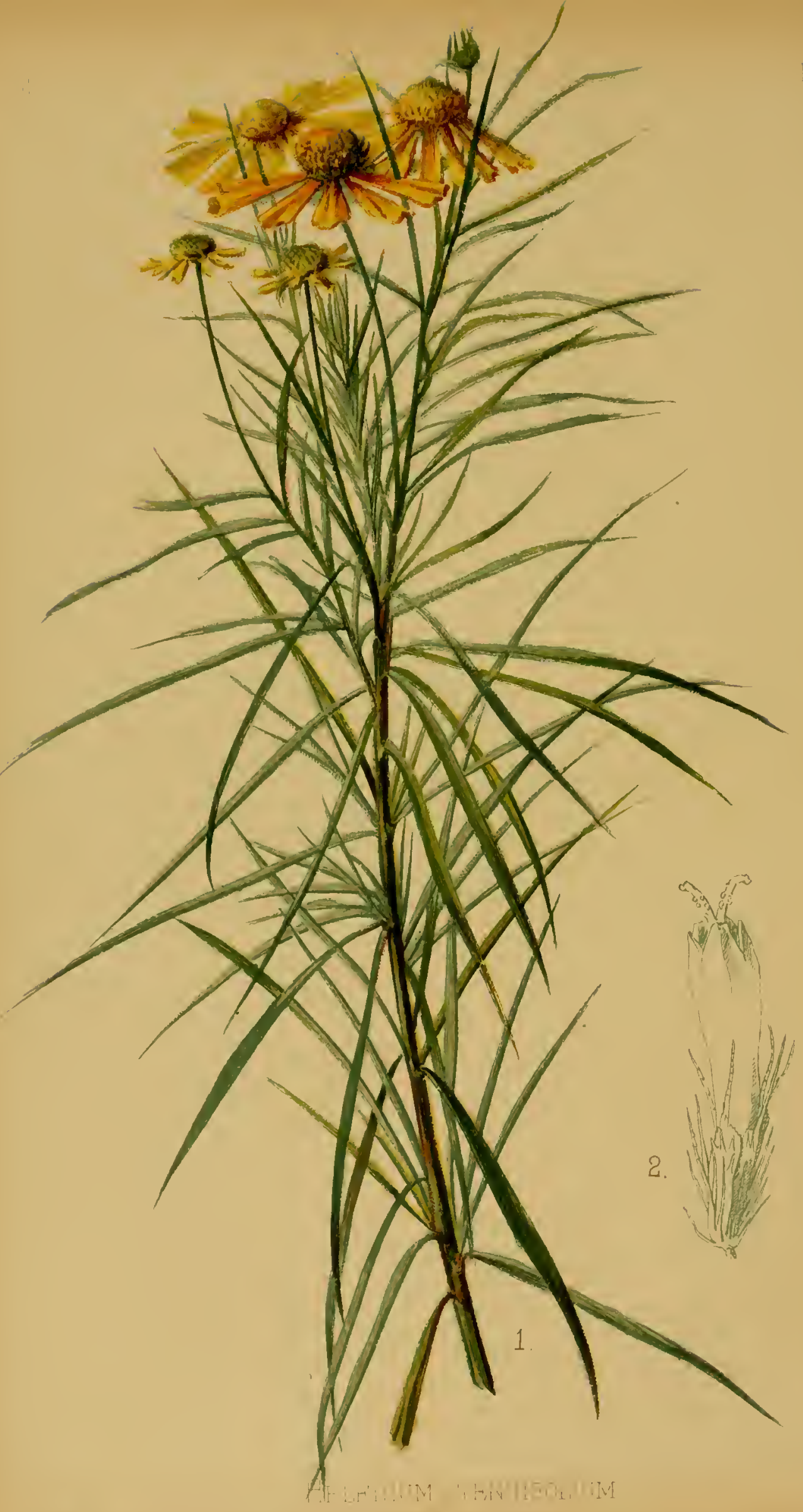




\title{
HELENIUM TENUIFOLIUM.
}

\author{
SLENDER-LEA VED SNEEZEWORT.
}

NATURAL ORIER, COMPOSITE. (ASTERACE.T, OF IIINDLEY.)

\begin{abstract}
11Hi.ENIUM TENUIFOLIUM, Nuttall. - Smooth; stem slencler, very leafy; leaves narrow-linear, entire; heads on long and slender peduncles; scales of the invelucre subulate; scales of the pappus ovate, entire, aloruptly awned; achenia villous. Stem one to two fect high. Branches erect. (Chapman's Flori of the Sutthern L'uitut State's. See also Wood's Class. Brok of Bithny.)
\end{abstract}

ELLOW, aster-like blossoms are so common among the wild flowers of the United States that they are not very likely to attract special attention, unlcss they are peculiarly beautiful. Our Hclcnimm tcnuifolium is one of these exceptions, and whoever has seen it in its native places - the prairies of Texas and Arkansas, which are celebrated for their wild flowers - will bear testimony to the fact that it adds largely to the general loveliness of the scenery in those parts of our common country. Those, however, who have not had the privilege of gathering this plant in its native wilcks can grow it in garclens, in which, according to the testimony of the florists who have cultivated it, it is a most desirable acquisition. In England, where good border-flowers are especially sought, it is so highly appreciated that the "Garden," a leading horticultural magazine published in London, recently gave an illustration of it, showing what a beautiful flower it will make under careful cultivation. This engraving represents the plant as a perfect bouquet, the rounded flower-cluster of the single plant measuring two thirds of its height, and exhibiting many scores of blossoms all expanded at the same time. Prof. Wood says that our spe- 
cies commences to bloom as early as April, and continues until November, which would make it as near an ever-blooming garden plant as one could desire. Dr. Chapman, however, limits the time to September.

It may be noted that much of the effect of these yellow Composites depends on their foliage, which very generally is rough and coarse-looking. But in the case of our present species, the long and slender leaves give a peculiar character of elegance to the whole plant.

Hclcninm is not a large genus, and has only four representatives in the eastern part of the United States, and a few more in the western part. It was thought at one time to have some resemblance to the Inula. Hclcnium, or Elecampane, and hence its present name was given to it. Our knowledge of the Compositc has, however, made such great strides since the time of Linneus that but few persons would now think of comparing our genus with that of Inula. In structure it would best compare, probably, with Gaillardia, a closely allied genus, although there is really not much resemblance in the general appearance of the two genera. But even in the structure there are important differences, as in our plant the yellow, strap-shaped flowers, or the ray-flowers, as the botanists would say, have perfect pistils, and produce seeds, while in Gaillardia these ray-flowers are barren. The greatest similarity will be found in the seeds or achenes, in the form, which is top-shaped in both genera, as well as in the scales which constitute the pappus. Each floret of a Composite is a complete little flower in itself (see Fig. 2), having its reproductive organs in the centre (although these are sometimes wanting), and two floral envelopes answering to the corolla and the calyx of other flowers. The limb of the calyx, however, or the pappus, as it is called in Composites, very commonly assumes the shape of extremely slender bristles, which are popularly known as down. These bristles adhere to the seed after it has ripened, and an example known to everybody is found in the seeds of the Dandelion. But in some Composites the pappus is more like an 
ordinary calyx, and appears in the form of chaffy scales. Thus in our genus the pappus (see lower part of Fig. 2) consists of fine, chaffy scales, with a long, awn-like bristle on the tip of each, and this peculiarity it shares with Inula.

As a mark of distinction from other species of Ifclonizm, we may note that the achenes or seeds, to the top of which the pappus is affixed, are covered with silky hair in our plant (also shown considerably enlarged in Fig. 2), while they are smooth in some other species. All of the species of the genus have a five-cleft corolla, like the $H$. tcnuifolium, with the cxception of a single one, in which the corolla is four-cleft. It is also worth noting that the leaves of all the species growing in the United States are clecurrent, that is to say, they extend clown along the stem. Even in our very narrow-leaved IT. tcunifolium this peculiarity exists, although it is so slight that it cannot be shown in a drawing. These very narrow leaves furnish the chief characteristic of our species.

The botanical name of the genus Ifclonimm is connected with Greek history. It is said that the fair but frail Helen, the eloping wife of Menelaus, for whose sake the siege of Troy was undertaken, was a cultivator of flowers, and that in her collection she had a plant which would destroy serpents. The name of the plant mentioned as Ficnium by Pliny is supposed to have been suggested by this story. Another version is that the original Hclcnizm sprang from the tears shed by Helena; and the floral cmblematists have therefore made this plant the representative of tears.

The common name of Hclenium is "American Sneezewort," a name which has been given to it because, if reduced to a dry powder, it induces seneezing, like the Achillca of Europe. Hclenium temifolium is therefore the "Slender-Leaved Sneezewort."

Our species, as well as its relative, the $I T$. autumnale, has made a name for itself in pharmacy. Dr. J. N. Bigelow, a wellknown botanist and clistinguished physician, read a valuable paper on its virtues before the Detroit Academy of Míedicine, in 
February, IS72. The plant, in spite of all its beauty, seems to be extremely poisonous to some species of cattle. It appears, from a report by Dr. Lewis, that in I $\$ 66$, during the civil war, many of the horses of a company of cavalry stationed near Goodman, Miss., died from eating of the Sneezewort. Dr. Galloway, of Kosciusko, Miss., noted the effect produced on horses by this plant. "The first effect observable," says this author, "after a horse or mule has swallowed a bit of the weed, is a twitching of the eyes and a dodging of the head, as if to avoid some imaginary blow." According to the same investigator the twitching of the muscles gradually extends to other parts of the body, and the spasms increase until death ensues, or the animal is relieved by the administration of oil. Horses, however, rarely touch the plant, unless they are pressed by hunger, or are hitched near by it. Dr. Galloway gives an account of a clrove of twenty-five ponies from Texas, which were turned into a lot where some of these herbs grew, and of which eleven died from the effects of the poison. Sheep, on the contrary, seem to eat the plant without injury; and it does not appear to be fatal to cows, as Dr. Hale merely remarks that it imparts a bitter taste to their milk. Upon the human system it produces the same effect as on horses, as shown by the case (reported by Dr. Galloway) of several persons who had eaten of flour with which some of the plants had been ground up. Dr. Bigelow thinks that the Sneezewort, if properly handled, may become of great value in nervous diseases.

The Hclenium tonuifolizm was quite unknown to the earlier botanists, and was first discovered by Nuttall in his expeditions in Arkansas towards the latter part of his career. Its home is from Georgia to Louisiana, according to Prof. Wood. On the western side of the Mississippi it is found from Southern Texas northward to Southern Kansas.

Explanation of the Plate. - I. Utpper portion of a flowering branch. - 2. Disk floret, with its immature achene, enlarged. 


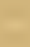
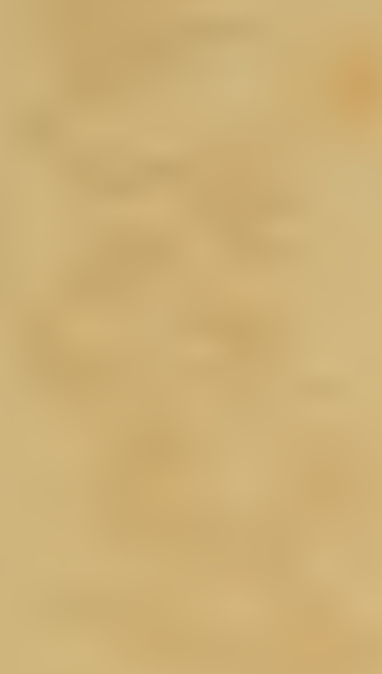

(n) 


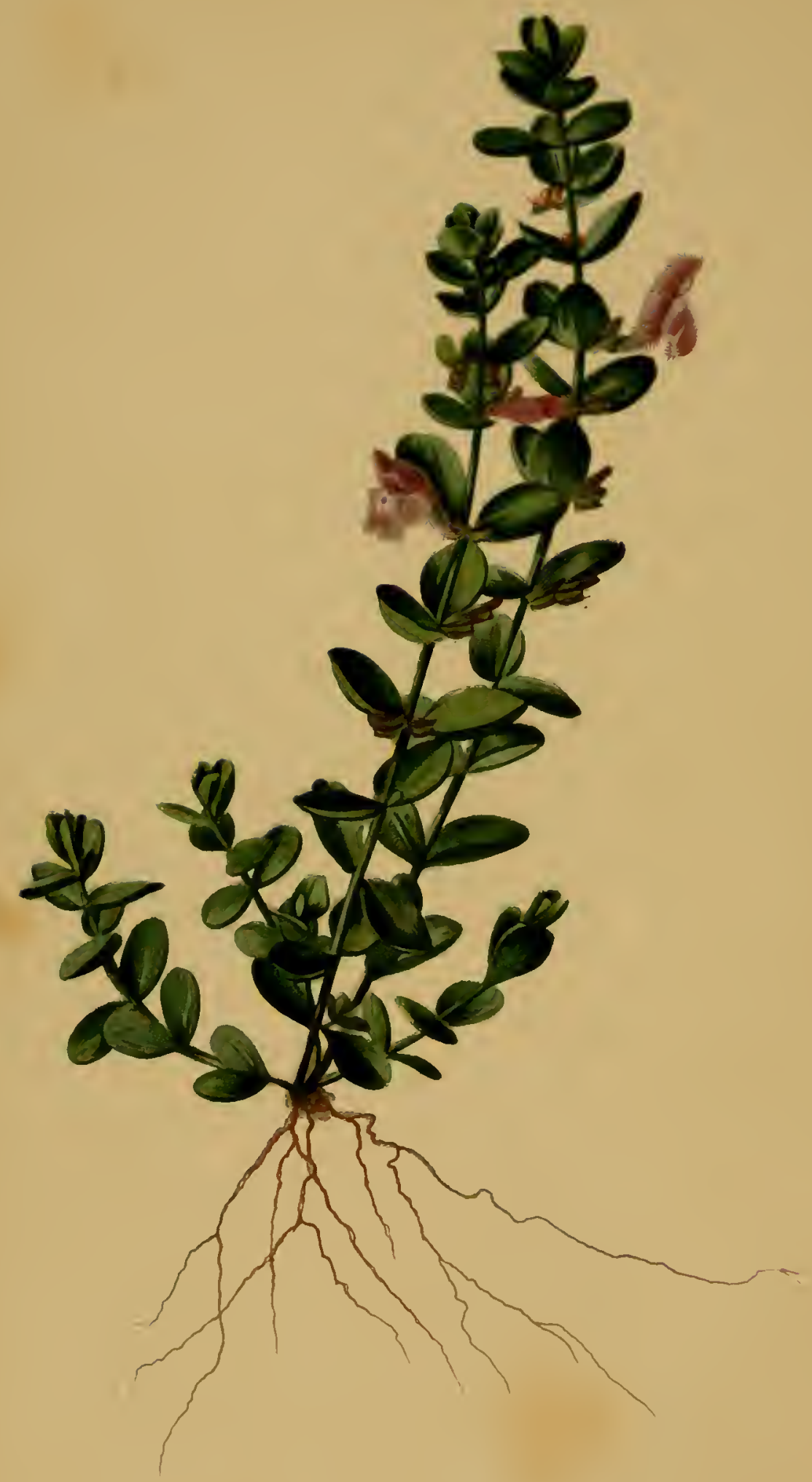




\title{
SCUTELLARIA WRIGHTII.
}

\author{
WVIGHT'S SKULLCAP. \\ NATURAL ORDER, L.ABIATA. (LAMACEE OF LINDLEY.)
}

\begin{abstract}
Scltellaria Wrichtil, Asa Gray.-Neither stoloniferous nor tuberous, sending up many stems from a perennial woody root, about half a foot high, minutely pubescent; leares ovate and spathulately oblong, quite entire, subscssile; corolla duwny-pubescent, viulet, six to seven lines long, cnlarging considerably upwards, lips of about equal length; nutlets small, minutely granulated. (Gray, in Procedin,ss of the American Acudemy of Arts and Sciences, Vol. VIIl, IS72, p. 37G.)
\end{abstract}

6E natural order of Labiate was so named from the two13. lipped, or labiate, corollas which are found in the flowers of most of the species belonging to it. The name, however, is not expressive in all cases, as not all Labiata have lips, and as labiate flowers are also found in other orders. Prof. Lindley's mame, Lamiaca, which he gave to the order from the genus Lamium, or "Dead Nettles," as they are called in England, would therefore seem to be the more appropriate of the two. The order is one of the most interesting in the whole vegetable kingdom, not only from the peculiar structure of the flowers, and from its relationship to other orders, but also from the immense number of its representatives in all parts of the world. It has been estimated that in the United States one in every forty of the whole number of species comprised in the phrnogamic flora is a Labiate. Mints, saģes, thyme, horehound, savory, catmint, pennyroyal, and many other well-known plants belong to the order. The peculiar aromatic odor for which the herbs just named are noted, i.s produced by an oil contained in vesicles which are open at the apex, so that the odor can escape freely through the orifice. In other plants the oil is imbedcled in the 
tissues, and cannot escape unless it is pressed out. This explains why we rarely smell an orange without handling it, or without its having been handled, while the odor from a bed of mint is wafted to us on every breeze.

We have said above that not all Labiata have labiate corollas, and that not all flowers with labiate corollas are Labiatc. It is not always possible, therefore, to distinguish the order at first sight by the shape of the flowers, and there are genera among the Icrbonacca, the Boraginacca, and the Scrophulariacce, which might easily be mistaken for Labiata. But however closely the floral structure may resemble the Labiates, there are always certain other inclications which will lead the student in the right direction. Thus square stems never occur among the Boraginacac, while they are one of the leading characteristics of the Labiate. Among the Vorbcnacea there are some species with square stems, but the ovary is single, while in the Labiata it is invariably deeply four-lobed. In Scrophulariacec, finally, the ovary is a two-celled pod, with the pistil proceeding from its apex, while in Labiate the pistil rises up between the four lobes of the ovary, and distinctly from their base. There are many other points of difference between the four orders named, but those we have just alluded to are the leading ones, and will be sufficient to enable the student to decide in doubtful cases.

Of the genus Scutcllaria, to which our species belongs, Dr. Bromfield remarks, in his "Flora Vectensis," that "in the structure of the flowers, and in general habit, this genus betrays the strong affinity of the natural orders Labiata and Scrophulariacce." In the last-named order, the embryo in the seed, as seen under the microscope, is always more or less curved, while in Labiata it is straight, with very few exceptions. Scutcllaric is one of these exceptions, and hence the affinity with Scrophulariacca is apparent also in this feature.

Of all the genera belonging to the order, Scutellaria is one of the most important, as it embraces about one hundred and fifty species. It seems to have its home-centre in the United States, 
a greater number of species being found here than in any other country. Geographically the genus is almost entirely restricted to the temperate and cold regions, and only a few of its species are found in the mountain districts of Brazil and Peru. In the higher lands of -Mexico the number of its representatives is somewhat greater, and it keeps on increasing as we travel northward. Across the Behring Straits it is found largely in the Russian possessions in Northern Asia, and then decreases as it travels westwardly, until in England it is reduced to two species. The species with which we are specially concerned is a native of Texas, where it was cliscovered, at a comparatively recent date, by Mr. Charles IVright, an indefatigable collector, whose researches in Cuba and in Texas were of great value to science. It was subsequently collected in June, $1 S_{72}$, on rocky banks near Dallas, Texas, by Mr. E. Hall; and Dr. Gray, who gave an account of Mr. Hall's collections, named the species in honor of the original discoverer.

The ealyx of the Scutclarias furnishes a remarkably interesting subject for study. On the upper lobe or clivision of the ealyx, there is a small coneave appendage, which seems to be attached to the lobe by a hinge; and when the corolla fades and falls, this appendage closes over the mouth of the calyx, thus effectually preventing the escape of the seeds. Referring to this fact in connection with a European species, an English writer say's that, "after the closing of the mouth, the calyx splits throughout its whole length, along its two lateral rib-like sutures, the dehiscence extending across the saccate process, whence the entire upper half of the calyx is thrown off, leaving the lower half persistent." The particular object of this singular contrivance, or its use to the plant, is not clear; and it is quite likely that a careful observation of it, in the light which the recent developments in the science of morphology and vegetable physiology afford, would lead to valuable results.

The genus Scatellaria is also quite instructive, morphologically considered, in other respects. As a reference to the plate 
will show, there is scarcely any difference in our species between the base leaves and those at the apex of the flower-stalk. The flowers, therefore, are axillary, that is to say, they appear in the axils of the leaves. But if we get together a large number of species of the same genus, and arrange them side by side, we may notice a gradual metamorphosis of the leaves towards the apex of the stem, until they become mere bracts at the base of the flower; and then the inflorescence is no longer said to be "axillary," but is termed "spicate." Proceeding still further with this systematic arrangement, we come to some species in which the upper leaves have almost entirely disappeared, so that the inflorescence is "sub-racemose." In addition to this suppression of the leaves we find sometimes that the elongating development of the upper portion of the stem has been wholly arrested, and in that case we have the flowers in heads, or "capitately clustered." This gradual change from axillary flowers to flowers in heads, brought about solely by changes in, or suppression of, the leaves, and by the arrestation of the elongating development, is exceedingly instructive, as it serves to show clearly how the final form is affected by the varying activity of the growthforces.

The derivation of the botanical name, Scutcllaria, is not quite certain. It is generally supposed to be derived from a Latin word, signifying a little dish or salver, and to allude to the shape of the calyx. Dr. Gray supposes the allusion to be confined to the form of the appendage.

The English common name of the genus is "Skullcap," from the resemblance of the corolla to a skulicap or helmet. Our species has no special name of its own, and we must therefore be content with a translation of the botanical name.

IVright's Skullcap thrives very well in gardens, and makes a very neat ormamental plant. The specimen from which our drawing was made was grown at the Botanic Garden of Harvard University, at Cambridge, and was kindly furnished to us by Prof. Sargent. 

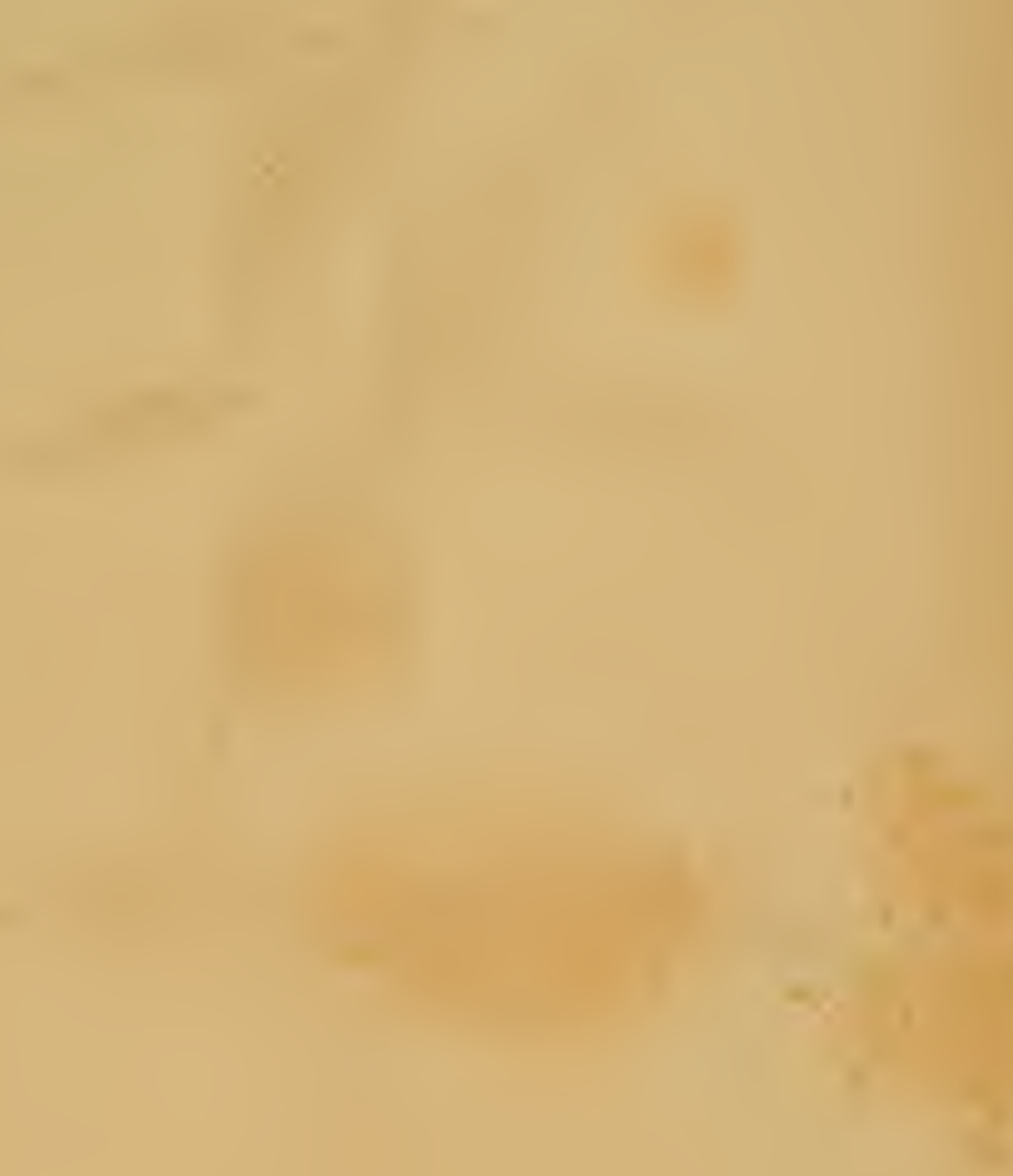


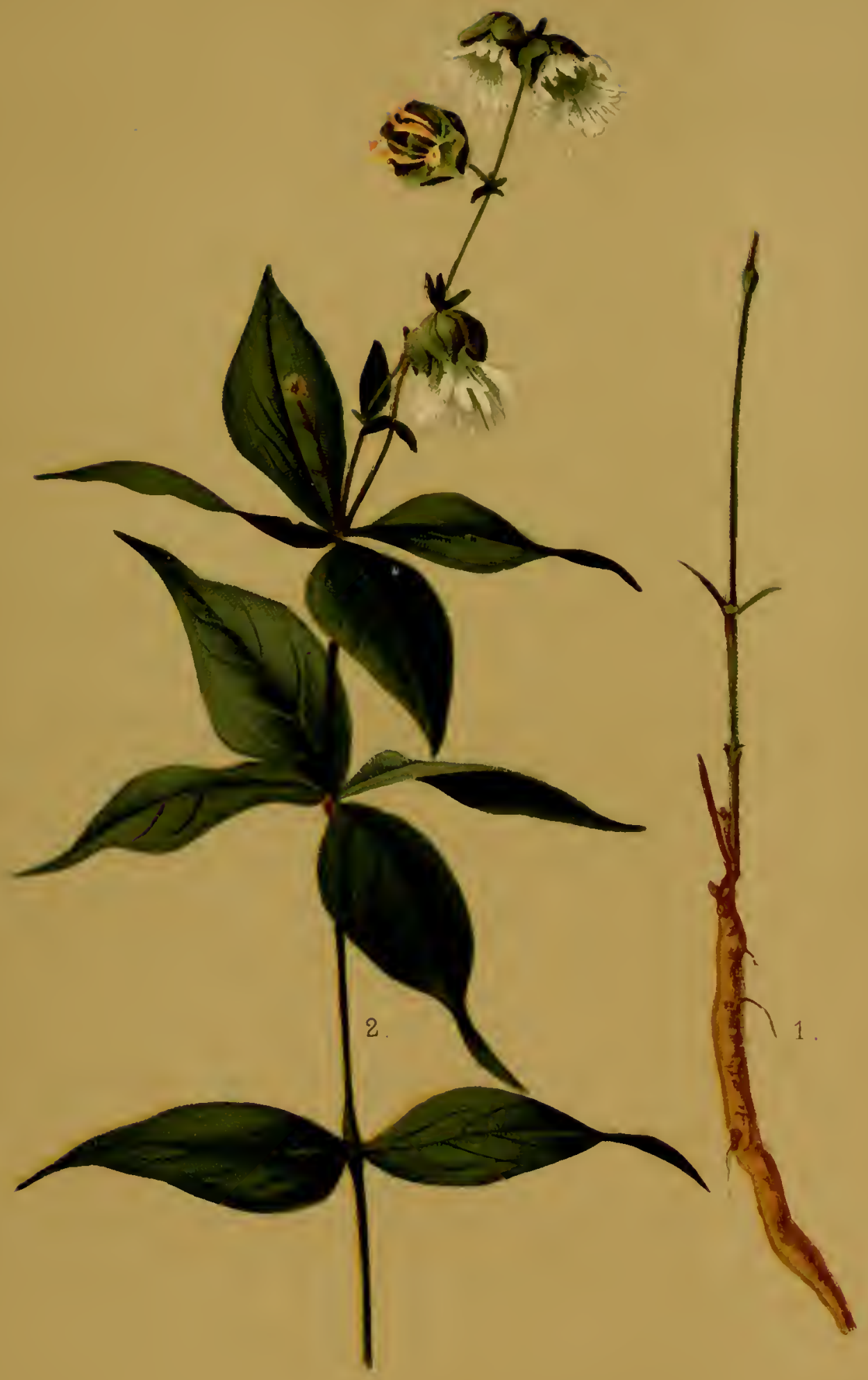




\title{
SILENE STELLATA.
}

\section{STARRY CAMPION, OR CATCHFLY.}

\author{
NATURAL ORDIR, CARVOPIIYLACER.
}

Silenf Strllita, Aiton. - Leaves verticillate in fours, oval-lanceolate, acumimate, sessile, one to three inches long; calyx loose and bladder-like; petals white, cut into a fringc, not crowned; flowers in an open terminal panicle. (1)arlington's Flun Costrica. See also

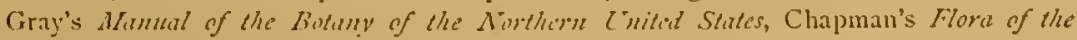
Southern ('mitid Statis, and Wood's Chass-Book of Botany.)

GE] HE plant now called Silcue stcllata was formerly known 20.0 as Cucubalus stcllatus; but Thomas Nuttall made Cucubalus a section of Silanc. Nriting of our plant in $1 S_{2} 7$, the author named, after describing several other species of the same genus, says: "The most remarkable species of the genus is C. stcllatus, deriving its name from the peculiar character of its leaves, being verticillated or stellated, and growing in fours; they are also minutely but closely pubescent, and of an ovallanceolate form, with a long acumination. The petals are white, divided almost like fringe, and, like Cucubalus Behen, or Campion (now Silcue inflata), the flowers are chiefly open in the evening."

It will be noted that Nuttall, as well as Darlington, whose description we have quoted at the head of this article, and indecd all other botanical authors, dwell with particular emphasis on the verticillate or peculiarly stellate character of the leaves, none of them, as far as we are arare, mentioning the fact that other arrangements of the leaves sometimes occur. The lower leaves, however, are generally in opposite pairs, as correctly shown on the plate by our artist; and, in Pennsylvania at least, which supplied the specimen from which our illustra- 
tion was drawn, the verticillate leaves occur only on a few of the upper nodes of the stem. Above these the leaves are again opposite, a fact which is alluded to in the description given by Dr. Chapman. These variations in the same plant are particularly interesting to students, as they show that the laws which produce none but opposite pairs of leaves on one plant, and cause verticils to grow on another, are in the main identical. It is such facts as these that hare paved the way for what is now known as the doctrine of evolution.

Cucubalus, under which name, as before stated, our species used to be known, is from two words, signifying a very bad sort of a weed. But why this name should particularly be applied to the original species is not very clear. At any rate, our plant is not "a very bad sort of a weed." It is generally confined to half-shaded woodlands, and no evidence is on record that it ever makes itself obnoxious to the cultivator.

The word Silenc, as most of our readers are aware, is derived from the Greck sialon, saliva, or spittle; and the general belief is that some of the species, which have a saliva-like cxudation, suggested the appellation. Contrary to this, a noted French writer opines that the name of the plant is connected with the Greek satyr Silenus, the foster-father of the god Bacchus, whose name, however, is said to have the same derivation as Silcne. But however this may be, certain it is that the English name Catchfly was given to the genus Silcne on account of the sticky nature of the species which compose it; and the fact that some of these plants make use of their viscid exudation to catch flies and other insects, long ago suggested to observant students the question whether some advantage might not be derived by them from this arrangement. Dr. Erasmus Darwin, in his curious work, "The Botanic Garden," published in the latter part of the last century, alludes to this question as follows: "The viscid material which surrounds the stalks under the flowers of this Catchfly, is a curious contrivance to prevent insects from plundering the honcy or devouring the seed." He also speaks of 
"The fell Silcne and her sisters fair,"

and gives the following warning to the unsuspecting bees and other insects, referring, under the designation of the "three dread sirens," to the three pistils of the flowers:-

"Haste glittering nations, temants of the air,

Oh, steer from hence your viewless course afar!

If with soft words, sweet blushes, nods, and smiles,

'The three dread sirens lure you to their toils,

Limed by their art, in rain you point your stings.

In vain the efforts of your whirling wings.

Go, seek your gilded mates and infant hives,

Nor taste the honey - only purchased with your lives!"

This question of the relations between insects and plants was not, however, followed up in Dr. Darwin's time; but in our own day, after having lain domant for nearly a century, it has again been taken up, and has become a very important feature of botanical study. Like all other scientific questions, it has gained in breacith as well as in depth, and enters not only into the discussion on the fertilization of plants, but has also had a great deal of interest added to it since the attention of scientific people was attracted by the so-called insectivorous or carnivorons plants. The Silcnes, however, have been rather neglected in this respect, and Mr. Charles Darwin, our celebrated contemporary, does not scem to have made any special use of the facts relating to them, in his works on the relations of plants to insects.

As Nuttall remarks, our flower usually opens in the evening; but in shaded woods it often remains open till near noon of the day following:

Of the common name, Campion, which $S$. stcllata enjoys, in addition to that of Catchfly, several explanations are given, but all are equally unsatisfactory. One theory is that it is clerived from the Latin campus, a field, in allusion, as Don says, to the fact that one of the species is " a pest in the fields." Dr. Prior suggests that it may be from "campionc, a battle-field, from having been used in chaplets with which champions in the public games 
were crowned." As guessing seems in order on this subject, we may as well venture another guess. Ancient writers say that a thick, dorny-leaved plant of this family was dried and used by soldicrs in the field as wicks for their lamps. For this reason, the name of Lychnis, from the Greek lychnos, lamp, has been given to some members of the family, and Campion might, therefore, have been applied to the plants of our genus, as they or their relatives supplied wicks to the soldiers while camping out.

Our plant will not, probably, ba considered highly ornamental as it is generally seen; yet a large bush, formed by numerous roots growing together and seen about sundown, is extremcly pretty, and would excite the admiration of any cultivator of flowers. It seems to have been one of the carliest of American piants to secure a foothold in English gardens, for Aiton tells us that it was grown by a Mr. Walleer at least as early as before the year 1696 . In our own gardens, however, it is not often seen.

In its wild state, the Starry Campion, or Catchfly, extends over our country, in the langruage of Mr. Sereno Watson, "from Canada to Georgia, and west to the Indian Territory." In most of the States contained within this area, it is abundant; but in New Jersey it does not seem to be very common. In Pennsylvania it flowers late in July; but Mr. Hyatt reports it as being in bloom in the early part of that month at Pcoria, Ill.

Explanation of THe PLATE.- $\mathrm{t}$. Peremial ruot, with the lower part of the stem clivested of its opposite leaves. - 2. Upper part of the stem, with upposite leaves, verticillate leaves, and flowers. 



\title{
STOKESIA CYANEA.
}

\author{
BLUE STOKESIA.
}

\author{
NATURAL ORDER, COMPOSIT E. (Asterace
}

STOKESIA CYANEA, L'Heritier. - Flowers all tubular, the marginal larger, ray-like, irregular ; scales of the involucre imbricated, in screral rows, the outer spinulous and leaf-like; receptacle naked; fruit four-angled; pappus of four or five awn-like, rigid, deciduous scales. Perennial; erect, with a downy stem; leaves alternate, sessile, entire, glabrous, the bracts spinulous at base, gradually passing into the scales; showy blue flowers in terminal large heads, outer corollas with the inner cleft deeper, limb spreading, palmate, imitating rays. (WVood's Class-Book of Botany. See also Chapman's Flora of the Southcrn ('nited Statis.)

HE plant represented on the accompanying plate is more than usually instructive, as its structural features, its morphological characters, its geographical relations, and its floricultural capacities are all so interesting as to make them worthy of the special attention of the student.

The structural features of the Stokesia cyanea are well calculated to show how artificial the so-called "natural system" of botany still is. In the order Composita, to which our plant belongs, the best arrangement is supposed to be that which divides the families according to the shape of the florets, and the two main divisions, therefore, are Tubuliflore, with tubular florets, and Liguliflora, with the florets strap-shaped. The Stokesia has been placed among Tubuliflore because the lower portion of its corolla is tubular; yet the upper portion (see Fig. 2) is so decidedly strap-shaped that the most "natural" position of the genus would seem to be among Liguliflora. We see, therefore, on what seemingly uncertain grounds some of the divisions of our system are based; and that a little more or less of cohesion in the leaves of the coroila may be reason sufficient 
for separating plants which by their whole aspect appear to be closely related.

Turning now to the morphologic side of our subject, we find that the manifestation of the transforming power in the conversion of leaves to involucral scales is remarkably regular in the Stokcsia. In many of the Composites there are no gradations whatever between the root-leaves and the involucre, or, in other words, the stem is quite naked. In our plant, however, the leaves are not only scattered all along the stem, but we may readily perceive a gradation in their development from below upwards. The lower leaves have entire edges, the next following have a few bristle-like teeth near the base, and those still higher are gradually shortened, with the number of teeth increasing in inverse proportion to their size. But even when the leaves have reached that period immediately preceding their transformation into florets, they look more like small leaves than involucral scales; and they retain this character to the very last, for even when the seed is quite mature, and when in other Composites the scales would be dry, the outer ones of the Stokcsia (see Fig. 3) preserve their green color.

An interesting fact connected with this plant is that it is the only species of the genus, and that the genus itself does not seem to be very closely allied to any of its neighbors. Those who are interested in the theory of evolution, and believe that every species has been derived from some other species by slow and almost insensible modifications of structure through countless ages, would therefore say that many of the links which connected our species with its parent form must have been lost. With the theory of crolution still in mind, we might even hazard a guess that the race of the species is nearly rum, and that it is doomed soon to die out altogether. This "guess" is based upon the fact that the plant shows very little inclination to vary, which may be interpreted as an inability to develop further. The only variation we have ever noted has been in the average height of the plants from different localities. Our plate 
shows the full size of the specimen which we used for our illustration; yet in some parts of the country the plants grow to an arerage height of two feet. We may add here that the admirers of our flower need not fear that they will have to mourn its disappearance soon, eren if our guess should turn out to be a true prophecy. In the light of the theory of evolution, a hundred thousand years or so, do not amount to much, and "soon" is altogether more likely to mean a million than ten years.

In its natural geographical range the Stokcsia cyanca is limited to a very small district, although it seems to be a hardy, vigorous plant in gardens, and takes care of itself very well. Even with the continned researches of local collectors, the area now known to be occupied by it is not much larger than that which we find recorded a hundred years ago, and this area, according to Prof. Wood, is restricted to the three states of South Carolina, Georgia, and Louisiana.

Our plant has long been known to the flower-loving public of Europe, having been introduced into England from South Carolina, about 1766, by James Gordon, the celebrated London nurseryman, after whom our Gordonia was named. In regard to its cultivation, Mr. Robinson writes as follows in his book called "Hardy Flowers": "The plant does poorly in cold soils and positions, but grown in pots it flowers very well in a cold house or conservatory in autumn." It is remarkable to find a plant which can very well bear our severe winters in our own gardens spoken of in connection with a green-house in the much milder winter climate of England. But Mr. Robinson is not alone in his estimate of the tender character of the plant as regards England, for Mr. Johnson calls it "a half-hardy evergreen, requiring a little protection in winter." From a paragraph in the London "Garden," it is evident that our rare and beautiful wild flower is an especial favorite in England. In a recent volume we read: "This plant has this autumn furnished the chicf supply of blue flowers brought to Covent Garden market in a cut state. They first made their appearance early in September, 
and were to be seen in the florists' shops until late in November. Those who desire a really good autumn flower would do well to grow this. The blue, aster-like flowers are very large and showy, and are borne on the end of every branchlet, each bloom being about three and a half inches in diameter, and apparently semi-double. In its late-blooming property consists its chief value, for late-flowering, hardy, really good plants are scarce. . . It is also very useful for conservatory decoration in autumn and winter." This extract shows how highly the plant is appreciated as an exotic in the Old World.

The name Stokesia is said to have been given to our species in honor of Dr. Jonathan Stokes, an English botanist, but it does not appear that he had any special connection with the flower. It first appears in botanical literature in a work published by C. Ludwig L'Heritier at Paris in 1788 . The plant was regarded as a Carthamus by many good European botanists, and had several specific names while it was in this genus, such as C. cyancus, C.lavis, and C. Carolinensis.

Its common name in England, we are told by Mr. Robinson in the book before quoted, is "Stokes' Aster," but not from any botanical resemblance to the genus Aster, for there is none in our plant. In America this beautiful native species has been altogether too much neglected, and has not even a common name. To remedy this defect we have translated the botanical name, "Blue Stokesia," although "Stokesia" alone might perhaps be thought sufficient, as there is only one species, and all its flowers are of the same color.

For the specimen from which our drawing has been made we are indebted to Prof. George Thurber.

Explanation of the Plate. - 1. A dwarf plant, full size. - 2. Single foret, the lower portion tubular, and the upper strap-shaped. - 3. Mature head, divided through the centre, and showing the position of an akene on the receptacle. 

Vol. L

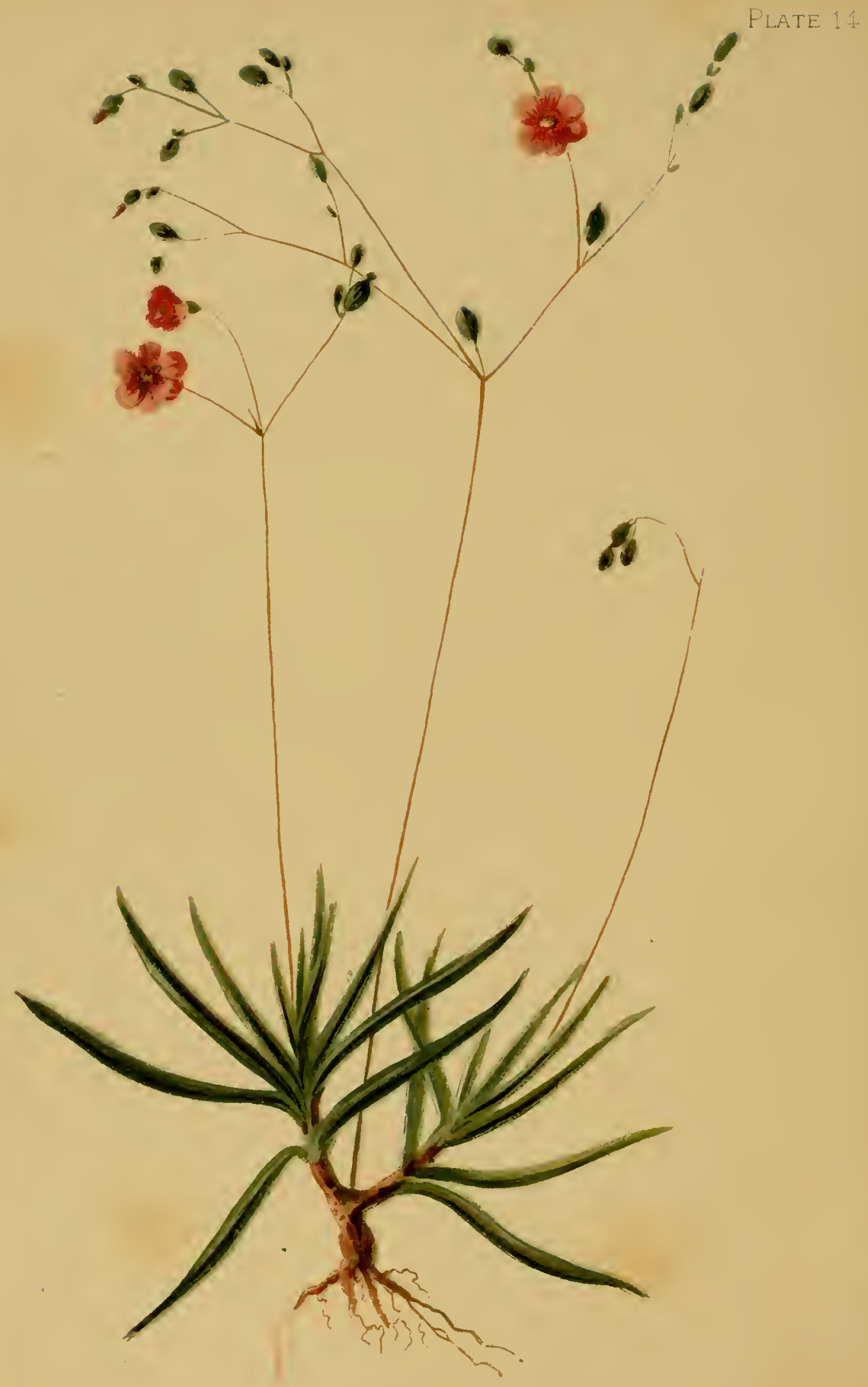

TALINUM TERETIFOLIUM 


\title{
TALINUM TERETIFOLIUM.
}

\author{
TERETE TALINUM; FAME-FLOWER.
}

NATURAL ORDER, PORTULACACE.E.

TAlinua teretifolium, Muhlenberg. - Leaves terete, acute; peduncles long, naked, and scape-like, dichotomous, and cymose at summit. (Darlington's Flori Ce'strica. Sce also Gray's Minull of the Botany of the Northern United State's, Chapman's Flora of the Southern Unitut States, and Wood's Class-Book of Butany.)

S.5. E have taken our botanical clescription from Darlington's
"Flora Cestrica," chiefly because its author discovered a station for the plant now under consideration near his own home, and therefore was enabled to observe it well; and again, because an opportunity is thus offered to point out how differences may sometimes arise between botanists, for which the student may be unable to account without an explanation. A reference to the works of Dr. Gray and Dr. Chapman will show that these authors give Pursh as the authority for the name of this species, while Dr. Darlington credits it to Muhl. enberg. The facts in the case are that the name appears in Muhlenberg's "Catalogue" of ISI3, while Pursh's "Flora of North America" was not issued till one year later, in I8I4. As far as priority of publication goes, Muhlenberg is, therefore, correctly credited. Strictly speaking, however, it is not merely the publication of a name that confers the right of priority in botany, but rather the pointing out of the characters by which the plant has acquired the right to bear a distinctive name of its own; and as Pursh was the first to publish the name, together with a description, those who credit it to him are quite as well (if not better) justified than Darlington. 
The genus Talinum was in existence long before our plant was placed in it. It was founded in 1763 , by Michael Adanson, a distinguished French botanist, who has been made famous by having the celebrated Baobob Tree of Africa, Adansonia digitata, named in his honor, - a tree which, on account of the great size of its trunk, and the age to which it is supposed to live, has been classed with the wonders of the vegetable world. Talinum is not a large genus, being confined to about two dozen species, and even of these several are referred to neighboring genera by some botanists. Yet the genus is rather widely distributed over the surface of the earth, having representatives in Asia, Africa, and America; but these separate representatives, or at least those found in America, are not very abundant, and are rather confined in their limits. The present species, T. terctifolizm, seems to have been long known to botanists, for Nuttail refers to an account of it given in a work by Leonard Plukenet, published in London in I691. In this work it is, however, described as a Stonecrop, under the name Scdum petraum teretifolizm Virginianum. Nuttall says that in his time it had been found in the mountains of Virginia, and "in Louisiana, near St. Louis," which sounds rather odd to us at present, unless we recollect that what is now the state of Missouri was then (ISIS) a part of the great Louisiana Territory. He also states that it was found "several years ago by Dr. Darlington near Chester, in the state of Delaware." This, however, is an error, as the location should have been "near West Chester, in the state of Pennsylvania." This little slip shows how next to impossible it is, even for the most particular author, - and such a one Nuttall certainly was, - to avoid making mistakes.

It is not surprising that the earlier botanists classed our plant as they did, for its succulent leaves in the summer season have very much the appearance of the leaves of a Stonecrop or Scdum. But if the structure of the parts of the inflorescence had been as well understood then as now, it would have shown that this 
classification was erroneous, since the difference between the Portulacaca, to which Tulinum belongs, and the Crassulacea, in which Scdum will be found, is easily recognized when once known. In addition to these scientific distinctions there is also another, which might be called a popular one. Scdums are generally evergreen, their winter freshness being, indeed, quite characteristic; but the foliage of this Talinum dies away entirely in the fall, and nothing remains but a short, thick, succulent root-stock, from which new plants start the coming year. Tinese root-stocks are so much like the color of the earth that, unless one looks for them very closely in the early spring, they may not be found; but the tuberous appearance is lost in the summer growth. By the middle of April the cylindrical, succulent leaves begin to appear, forming very pretty tufts in the clefts of the rocks on which (near West Chester, Pa.) the plant grows. The flowers first cone out in the month of June, and continue into August, and are sure to attract attention by their fine purple color, which is so rare among our native flowers. They must be looked for at midday, between twelve and two o'clock, at least according to the experience of the writer, who has never been able to find any of them open at any other time. In most cases within his observation the flowers remained expanded only for an hour.

In the progress of botany Talinum has had given to it several names, all of which are now regarded as synonyms. Thus Rafinesque proposed to call it Phemeranthes, or "Fame-Flower." To name it from the ephemeral character of its blossoms would certainly have been much more appropriate, but Rafinesque's name is still used by botanists as a convenient term to designate a section of the genus Talimm. The other synonyms are not important.

In view of the name Fame-Flower, and of the ephemeral character of the blossoms, we are tempted to imagine that the poet thought of our species when he sang:- 
"Why art thou doomed, sweet flower?

Is it because thy beauty is too bright,

Thou hast but one short hour

To spread thy fair leaves to the enamored light?

' $T$ is thus the loved and loveliest first decay,

But their remembrance may not pass away."

The derivation of the generic appellation Talimum, we are informed by Dr. Gray, is obscure. Pfeiffer, a German botanist, tells us, however, that it is the vernacular name of the plant among the Senegalese, and that it was adopted by Adanson as the botanical name.

Talinum terctifolium is found on rocks in North Carolina, or, according to Prof. IWood, even as far south as Georgia, and northward to Pennsylvania. Dr. Gray gives as one of its western locations the Falls of St. Croix River, Wisconsin; and Mr. Herbert E. Copeland found it in sand in the dells of the Wisconsin. The writer also collected it on the sandy plains at the foot of the Rocky Mountains, in Colorado. Prof. Aughey includes it in the flora of Nebraska; but in Kansas, according to Prof. Snow, it is replaced by its close ally, T. parviflormm. West of the Rocky Mountains it has not been found.

Mr. Aubrey H. Smith, in the "Proceedings of the Academy of Natural Sciences of Philadelphia," says that the plant does much better under cultivation than in its wild state, and the experience of the writer fully confirms this statement.

The plant is described in botanical works as having but five petals; the fact is rarely noted in these works that the first flowers of many cymose plants have a greater number of parts than those which follow. Our artist has faithfully represented the number six in the petals of the opening flowers. 



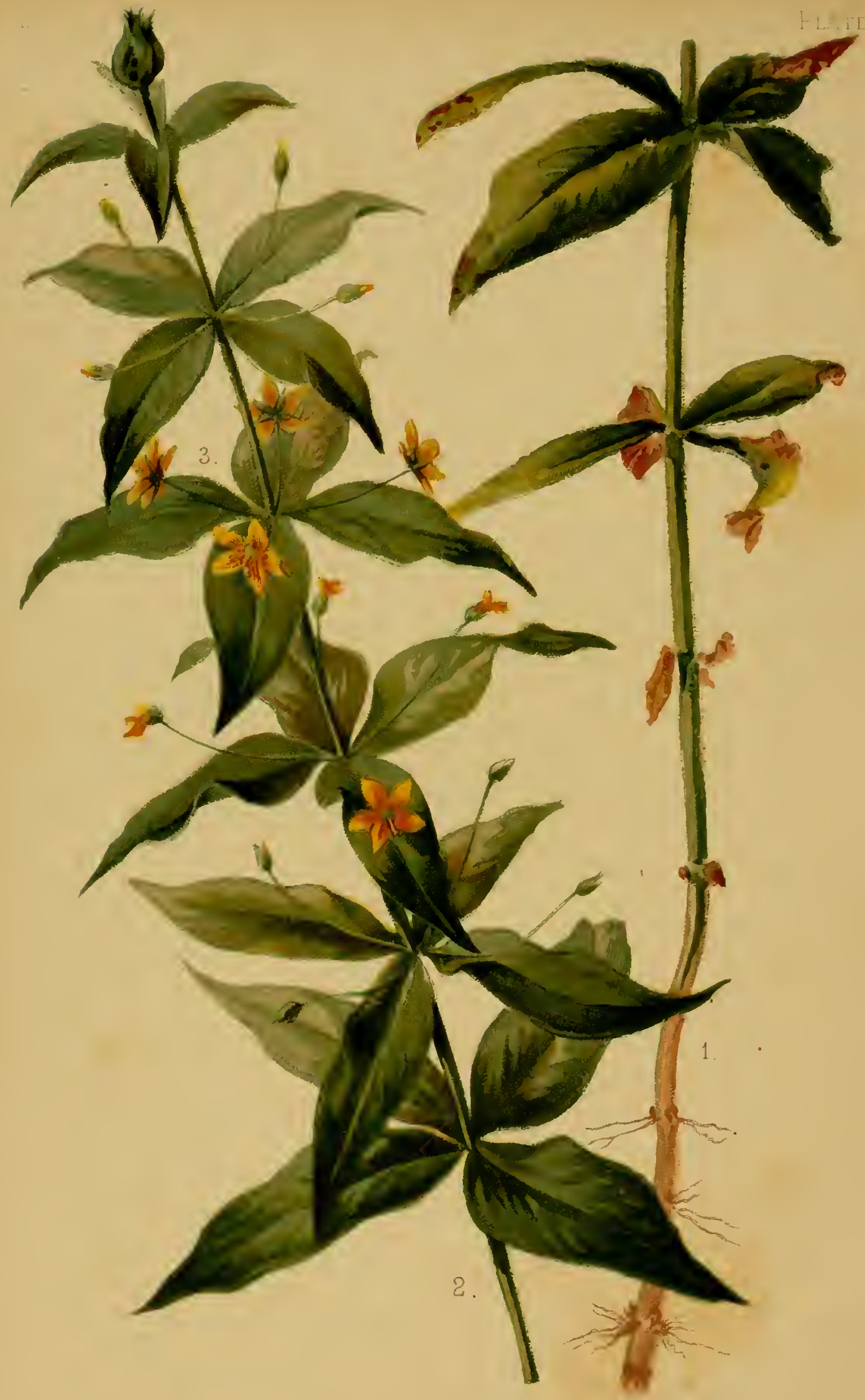




\title{
LYSIMACHIA QUADRIFOLIA.
}

\author{
FOUR-LEAVED LOOSESTRIFE.
}

\author{
NATURAI, ()RIDER, I'RLMLLACE.E.
}

1.jomachia guabrifolia, linnzus. - Stem a foot or two high, simple, leafy throughout, somewhat pubescent; leaves in whorls of four, sumetimes of three, five, or six, rarely only in pairs or partly scattered, oblong-lanceolate or the lower ovate, more or less acuminate (one to three inches long), equal, and with flowers on filiform pedicels from most of the upper axils, or sometimes the upper reduced to foliaceous braets and the flowers lousely racemose; divisions of the corolla ovate-oblong (two lines lung); ovules ten to cighteen. (Gray's Syuptical Flora of North Americat See also Gray's. Yumual of the Botany of the Northern ('nited Stutes, Chapman's Floriz of the Southern United Stutes, and Wood's ChissBook of Botiny.)

$\mathrm{N}$ the work from which we have quoted, nine species (both of which were formerly classed together as Lysimachia) are enumerated as natives of the United States. Among these there may be some species with larger flowers, or with flowers forming a more showy mass than the plant which we are about to describe, but none will probably be considered more strikingly effective in general appearance. This effectiveness, however, is due not only to the peculiar structure of the plant itself, but is also largely aided by the circumstances under which it is frequently found growing.

The Lysimachic quadrifolia has creeping roots; that is to say, it increases by short underground stems, which root at the joints, or places where leaves would appear, if the growth were above ground. Each plant produces a great number of these rooting stems, and these, being very strong, often manage to crowd out nearly all the other plants which grow near them, and to appropriate the ground almost wholly to themselves. Seen in 
these large groups and under the play of sunlight and shade, the plant, with its whorls of four leaves uniform in outline and at regular distances, makes quite a unique and beautiful picture which,once seen and enjoyed, is not likely to be forgotten. The picture is particularly impressive when the plant is in flower, as the golden yellow of the corollas then increases the contrast of light and shade in the general effect. The time when the blossoms are at their best - in Pennsylvania, at least, where our specimen grew - is in the middle of June.

In Pennsylvania, the Lysimachia quadrifolia loves to grow in open woods where there is considerable light; and in some cases it takes possession of railroad cuts and embankments, the dry soil not seeming to be uncongenial to it. Different botanists, however, locate it in various situations. Dr. Gray, in his "Synoptical Flora," refers to it as growing in sandy or gravelly soil, but says nothing of woods; while Dr. Chapman, writing of the Southern States, seems to have found it only in shady woods; and Prof. Wood gives low grounds and river banks as the result of his experience.

As a garden plant our Lysimachia will hardly commend itself to persons looking for gay border flowers; but it is excellently well adapted for use in the formation of "wild gardens," groups of trees, rocks, shrubs, and so forth, - to which so much care is now given. The plants for these "wild gardens," although left to grow somewhat as in a state of nature, are selected with reference to their period of blooming, their beauty of structure, or some other point of interest; and among these our species will be found an excellent element to work with.

The family history of Lysimachia quadrifolia is not without interest. The generic name is an ancient one, and there is a difference of opinion as to its origin and meaning, as is the case with most of such old names. In botanical works Tournefort, who wrote in 1700 , is usually credited with the authorship of the name; but this is correct only so far as it relates to its application in modern botany. The Romans already had a 
plant which they called Lysimactioa, and this is supposed to have been the L. tcnclla of Tournefort, a small creeping species of the section now known to cultivators as "Moneywort." As to the origin of the name, Salmon, writing in 1710 , says: "It is known in Latine as Ly'simachia and Lysimachion, so called from Lysimachus, king of Illyria (as I suppose), who was the first finder of it out." Milne, in his "Dictionary," says the name is derived "from Lysimachus, king of Sicily," and according to Pfeiffer it is connected with "Lysimachus, a king of Thrace." There was, indeed, a king of Thrace named Lysimachus, one of the generals of Alexander who divided among themselves the acquisitions of this conqueror after his death; but according to Pliny, the same name was also given to a precious stone with veins of gold running through it, and the similarity between the golden, coin-like flowers of what are supposed to be the original species, and the bright, gold-veined jewel, might easily have suggested the name. Another guess at the origin of the name, which is especially favored by modern authors, is based upon the etymology of the word. Pliny, according to Dr. Prior, tells us in his twenty-fifth book "that if branches of the plant be laid on a yoke of oxen when they are quarrelling it will quiet them." Sir William J. Hooker, in his "British Flora," alludes to this story, and on the strength of it suggests that the name may be derived from two Greek words, lysis, a release from, and mache, battle. This interpretation, indeed, accords exceedingly well with the very old common name of our plant, "Loosestrife," and has therefore been adopted by Paxton and by Johnson in their Dictionaries, and by all our American botanical philologists.

Our Four-leaved Loosestrife, if Dr. Titford be correct, shares to some extent the quieting qualities attributed to its ancient prototype, although it does not exert its power over oxen, but over another kind of creatures which Americans are often as anxious to control. In his "Hortus Botanicus Americanus," the author named writes as follows: "The virtues of this plant are vulnerary and styptic. The distilled water is cosmetic, and 
the smoke of the plant drives away mosquitoes." It is uncertain, however, whether there are any real medical virtues in our plant. Barton thought there was some merit in it; but Dr. Peyre Porcher, in his "Resources of the Southern Fields and Forests," the latest and most complete work on this subject, merely remarks that "our Lysimachias should be examined, as the leaves of L. mumularia (the European moneywort) steeped in oil have the power of destroying insects and worms which infest granaries."

The "Four-leaved Loosestrife" has been known since the early days of American botany. Plukenet, a contemporary of Tournefort, speaks of it as Anagallis lutca, and in the "Flora Virginica" of Gronovius, it is recorded as an "Anagallis with yellow flowers," sent to Europe by Clayton. Anagallis is a genus closely allied to Lysimachia, to which latter our plant was transferred by Linnæus. The L. hirsuta of Michaux and the $L$. punctata of Walter are now regarded as identical with L. quadrifolia, and these names are therefore synonyms.

The leaves of most of the species of Lysimachia are more or lesss dotted like those of our Four-leaved Loosestrife. In our plant the leaves are not always in fours, as its name indicates, but there are sometimes as few as three and as many as seven in a whorl. In a specimen now before the writer, the lowest whorl has three leaves, the next four, the third five, the fourth seven. The flowers also have this tendency to vary, and our faithful artist has shown a flower (marked 3 in the plate) with six petals.

Our plant is common in the seaboard Atlantic States as far as South Carolina, but has not crossed the Mississippi River, nor has it been collected west of Michigan, but is included in Mr. Coleman's list of the plants of that state.

Explanation OF THE PLITE. - I. The lower portion of the flower-stem. - 2. Upper portion of the same. -3 . A six-petalled flower. 


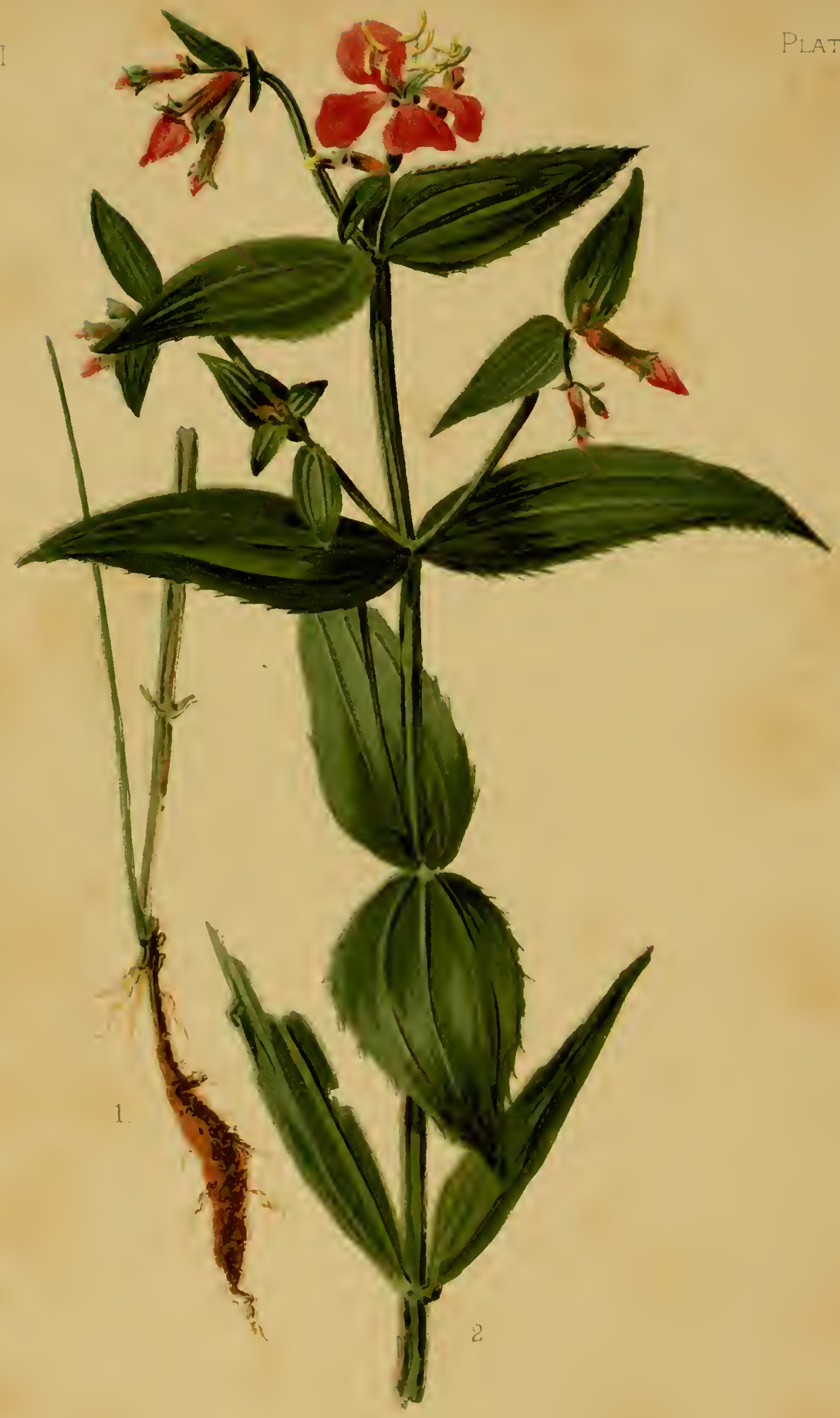




\title{
RHEXIA VIRGINICA.
}

\author{
MEADOW-BEAUTY.
}

NATURA1, ORDER, MELASTOMACEE.

RHEXia Vtrginica, Linnæus. - Stem square, the angles narrowly winged; leaves sessile, oval-lanceolate, ciliate-serrulate, and, with the stem, clothed with scattered hairs; calyx hispicl; stem one font or more high, often three-forked above; leaves with three (rarcly five or seven) prominent veins, one to three inches long, about half as wide, acute; flowers large, in corymbous cymes; petals bright purple, obovate, hispid beneath, caducous; anthers long and prominent, crooked, golden-yellow above, with a purple line beneath; style somewlat longer than the stamens, a little declined. (Wood's Class-Book of Botany. See also Gray's Mrantal of the Botrny of the Northern United States, and Chapman's Flora of the Southern Unitut Stutes.)

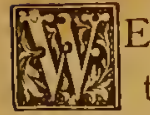

E have had occasion to remark before that it is not customary to trace botanical names beyond the time of Linnæus, and that he is therefore frequently credited with names which he found in use, and simply adopted. It is so in this case, for Linnæus himself informs us, in his "Genera Plantarum," that Gronovius gave the name Rhexio to the genus to which this plant belongs. But why the genus should have been called Rhexia has never been understood. Linnæus, in his "Philosophia Botanica," under the head of names derived from medical virtues, says it is from the Greek rhcris, which signifies a rupture. Prof. Wood gives this etymology, and adds, "some of the species are good vulneraries," - vulneraries being drugs useful in the cure of wounds. The authority for these statements, however, is not very apparent; and it is a singular fact that not only the genus, but also the whole order to which it belongs, seems to be strikingly destitute of medical qualities, all the virtues generally attributed to these plants being summed up in the statement that they are "slightly astringent." 
We may perhaps be able to find some clue to the derivation of the name, by going back to antiquity. Pliny mentions a plant called Rhexia, and says that its name is simply a synonym for Onochilus, literally "the ass's lip." But this last is now identified with the "Alkanah," or Anchusa tinctoria, the roots of which are used as a vulnerary, and which, according to Linnæus, is liable to be confounded in pharmacy with the "Red Root," Onosma cchoides, of Greece; Onosma literally meaning "that which asses are fond of," or "the asses' plant." Now, as Rheria has a root which is very like the "Red Root" of the ancients, it is barely possible that the employment of the Plinian name was suggested by this similarity. We must confess, however, that, although we have thus succeeded in carrying the name back eighteen hundred years, we have done nothing whatever to explain its meaning. We may therefore well say with Dr. Gray, that Rhexia has been "applied to this genus without obvious reason."

It is a curious fact that the root of this plant seems to be almost unknown to botanists. Barton says positively it is fibrous, while Fig. I on our plate shows it to be in reality tuberous. This fact has, however, been commented on by others before us, as shown by a communication in the "American Naturalist" for 1873 , in which a botanical correspondent writes: "This species produces fusiform tubers, and of course grows from them the following year. But Gray's 'Manual,' Chapman's 'Flora,' and Bentham and Hooker's 'Genera Plantarum' make no mention of it, and hence I infer it is not generally known." We are as yet unable positively to describe the way in which these tubers are formed. Most tubers are formed in a horizontal direction, but in some plants, as for instance in the Dioscorca Batatas, the Chinese yam, a descending root thickens, and forms a tuber, and this appeared to be the case in the specimen of Rhcxia Virginica which was procured for our artist. It may, however, have been accidental.

Lesquereux says our plant is very abundant in moist places 
in Arkansas, where it is known as "Deer Grass," because it is a favorite food with the deer. But as this name is now given to all the species of the genus, we have preferred to adopt "MeadowBeauty" for our common name, as this applies to our species only, and is quite as extensively used as the other.

In English gardens the Meadow-Beauty is the only species of Rhexia cultivated, and is so much prized for its beauty that it has lately obtained the honor of being selected for a colored plate in Mr. Robinson's "Garden." As much attention has been given to the plant by cultivators in England, the notes of experience collected there may be of use to our readers, and we therefore subjoin them. "The Meadow-Beauty," says "The Garden," "introduced many years ago from the United States," - we may add here, by way of parenthesis, that Aiton reports it as growing in "Banister's Garden" in 1704, - "and now but little known, is a hardy, herbaceous perennial, deserving of a more widely extended cultivation. ... In the open border it blooms in July and August, when the effect produced is very striking. The most luxuriant growth is produced by growing it in ground somewhat swampy; but well-developed examples may be had in any ordinary good soil to which an addition of peat or leaf-mould has been made. The Meadow-Beauty may also be cultivated with much success in pots, and the plants usually bloom more freely when so grown than when in the open border. In raising a stock from seed, sow early in March, and place the seed-pot in a moderate temperature. Keep the seedlings in pots till the following spring, and place them in a shady position during the summer, and in a cold frame during the winter."

In its geographical relations the Rhexia Virginica is one of the most interesting plants of the United States. The order to which it belongs, Mclastomacea, is a comparatively large one, containing probably a thousand species, and by far the larger portion of these inhabit the tropical parts of the American continent. The very few species which extend into the United States are all included in the genus Rhcxia, and, more curious 
still, are confined exclusively to the Atlantic portion, none having as yet been discovered on the western coast. Of the few species of which our country can boast, the Meadow-Beauty extends the farthest north, being found, according to the Portland Catalogue, in the State of Maine. Dr. Gray says it grows in sandy swamps; and he limits it northward to Eastern Massachusetts, giving its range thence to Pennsylvania, Wisconsin, Illinois, and southward. Dr. Chapman locates it in sivamps, chiefly in the upper districts, Mississippi and northward; and according to Prof. Wood it grows in wet grounds, Massachusetts to Illinois and Louisiana. Its flowering time, according to the two lastnamed authors, is in July and August. Of more special locations, Dr. Darlington records it as growing in slaty swamps in Chester County, Pa., but not common. Beck, as long ago as I 826, noticed that it grew sparingly on the banks of the Mississippi, sixteen miles south of St. Louis; and it is included in Geyer's lists of the plants of Illinois and Missouri, of the year 1844. As already noted, it grows in Arkansas, and is recorded in some Texan collections. It is not found in Kansas, but Prof. Aughey includes it in the flora of Nebraska, which is all the more remarkable as it has not yet been discovered in Iowa. As it occurs in Nebraska, west of Iowa, and in IVisconsin, on the east, we might certainly expect to find it in some lowa collections, and it seems almost probable that further investigations will yet add it to the list of lowa plants. It may be of value to keep these data on record, as they will give a clue in after years, if geographical changes should then be noticed.

To the lover of the beautiful, the bright color, both of the petals and the foliage, will be very pleasing. In its general aspect the plant is of a formal order of beauty; yet the strict symmetry and unity which appear in all its parts, even to the flower-buds, make it emphatically a work of art from the hand of nature.

EXPLANitiov of THE PLATE. - I. Flowering branch with its first expanded blossom 2. Lower portiou of stem, showing tuberous root. 



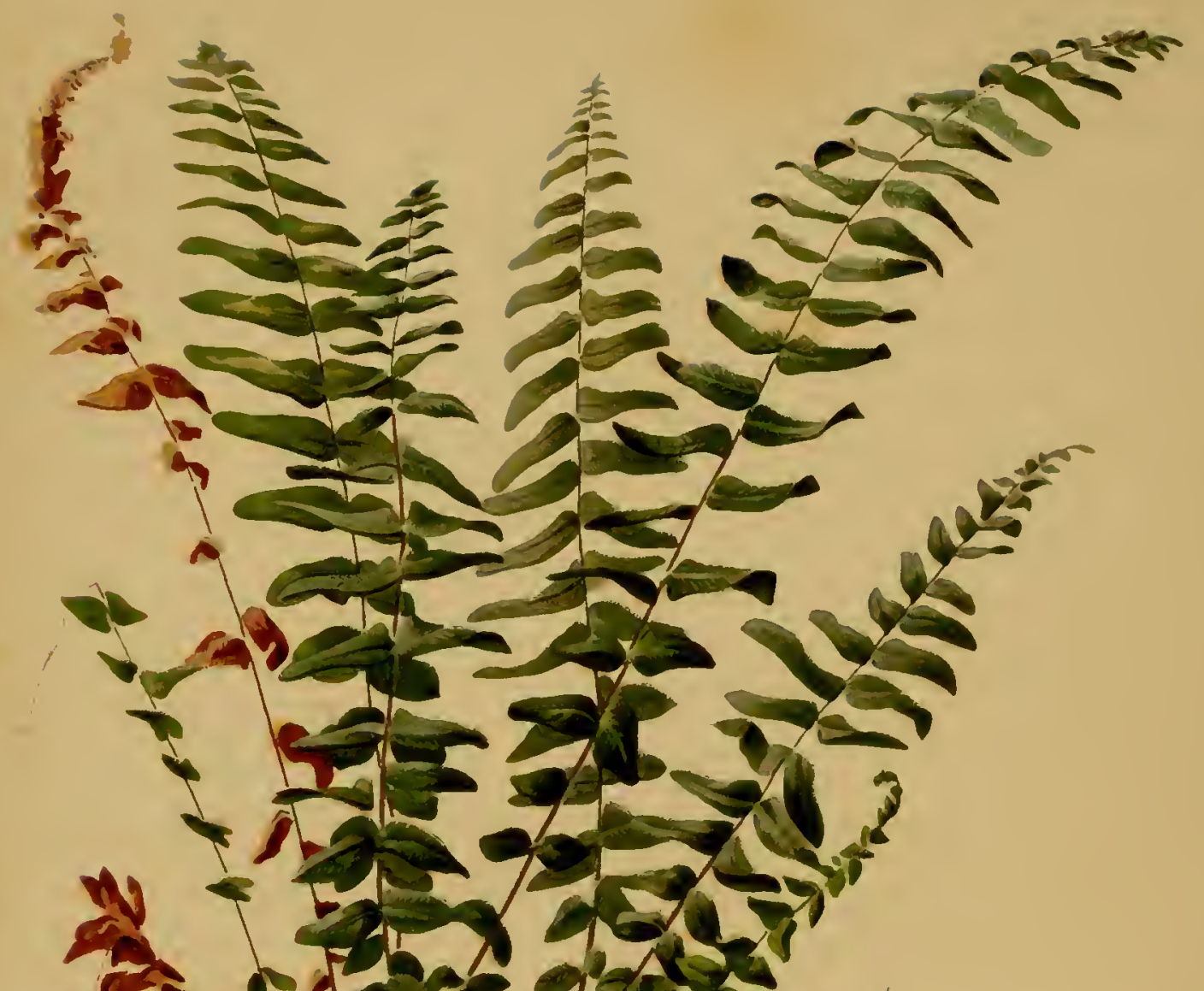
a r.
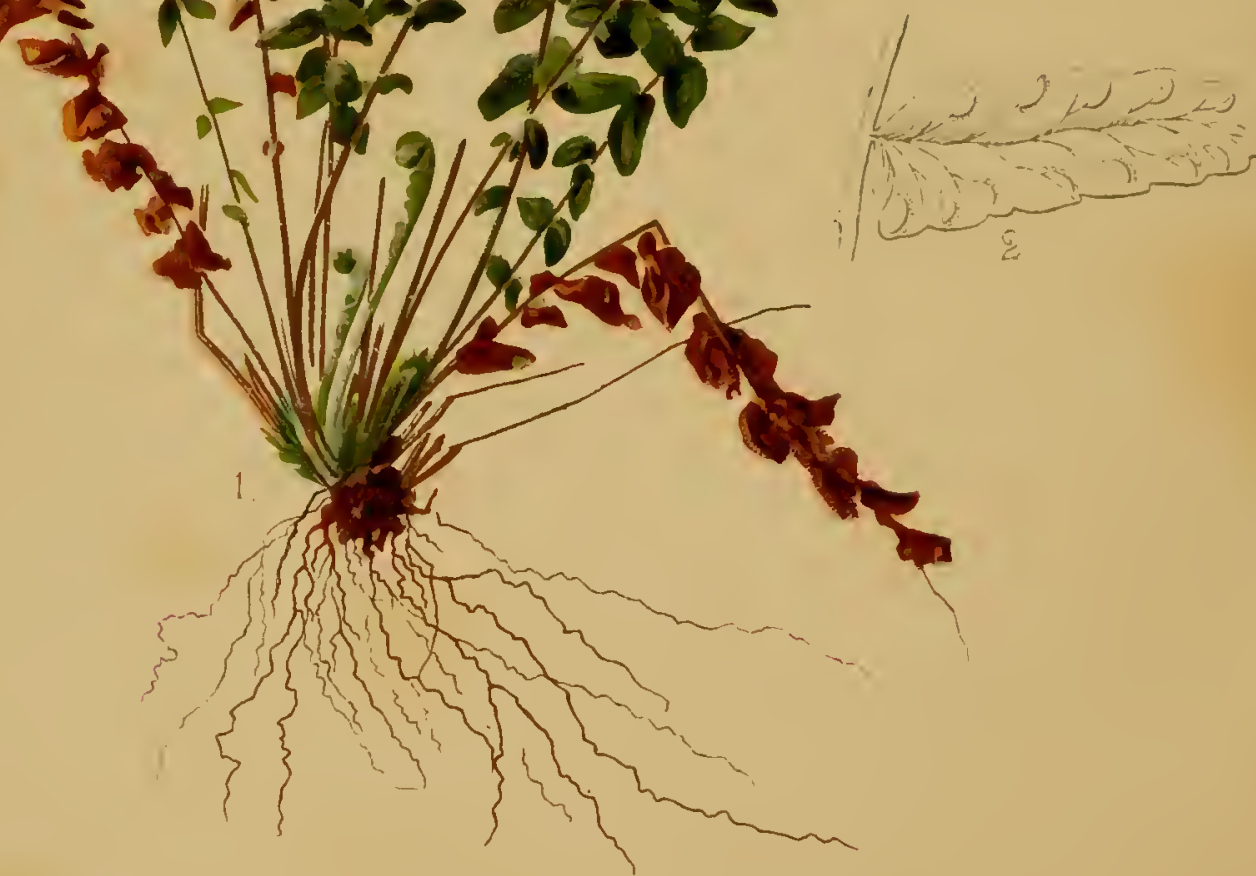


\section{ASPLENIUM PARVULUM.}

SMALI,ER EBONY SPI,EENWORT.

NATURAL, ORDER, FILICES (IOIYPODIACEA).

AspliniUM PARVulum, Mertens and Galleotti. - Frond linear, pinuate; pinnxe oblong, obtuse, entire, auricled at the base; stipe and rachis shining-brown, somewhat chamelled. Stipe about an inch in length, shining. Frond about three inches, attenuatcel at the apex. Pinna sub-opposite, sessile, three to four lines long, and onc to two lines lrond, entire, auricled at the base on the upper side, a smallcr auricle on the lower siclc. Sori crowded, almost covering up the under surface. (Nertens and Galleotti, Mlémoire sur les fouscrives du MIcxique.)

E never look upon a fern without wondering why it was that the carlicr polite writers almost entirely overlooked the gracefulness of these plants, and sometimes even spoke of them in contempt, or coupled them with disagreeable associations. Shakespeare alludes but once to the ferm, in the second act of the First Part of Henry IV, where he makes Gadshill say, as he is planning a robbery with a confederate: "We steal as in a castle, cock surc; we have the receipt of fern-seed, we walk invisible"; to which the confederate replies: "Nay, by my faith, I think you are more bcholden to the night than to fern-seed for your walking invisible." Gadshill's remark alludes to the popular belief that "fern-seed" has the power of making the person invisible, and this superstition was probably based on the mysterious manner in which ferns are propagated; for it was well known, even in Shakespeare's time, that ferns are not fertilized like ordinary flowering plants.

Modern pocts have made some amends for this curious disregard on the part of older witers; but still the ferns are neglected to an extent which it is difficult to account for. In one of the 
poems of Burns, a poet who was always keenly alive to the beauties of his native land, we find what is, perhaps, the warmest tribute of admiration ever paid to the fern. Comparing his own country with foreign lands, the great Scotch bard says:-

"Their groves of sweet myrtle let foreign lands reckon, Where bright beaming summers exalt the perfume; Far dearer to me yon lone glen o' green breckan, Wi' the burn stealing under the lang yellow broom."

The "breckan" or fern mentioned in these lines is the Ptcris aquitina, or Common Brake, one of the commonest species of the British Isles. It is the one of all others which the student of English literature would understand when he reads simply of "the fern," without further qualification.

Our own poets, like those of Europe, have also had but little to say of ferns. Bryant, usually overflowing with a love of nature, and with innumerable references to her floral treasures, does not even mention the fern in that beautiful poem, "The Fountain," to which one would turn first of all with the expectation of finding a reference to it. Indeed, we can recall only one stanza in all the works of this delightful poet in which the fern is named. This stanza is found in "The Two Graves," and runs as follows :-

\footnotetext{
"Two low green hillocks, two small gray stones, Rose over the place that held their bones; But the grassy hillocks are levelled again, And the keenest eye might scarch in vain, 'Mong briers and ferns and paths of sheep, For the spot where the aged couple sleep."
}

By the emblematic writers the ferns have been dedicated to sincerity; but the association of ideas is not quite clear, although it might, perhaps, be saicl that the simple, quiet beauty of these plants, which unfolds itself at onee and without reserve to all those who look upon them, is suggestive of the quality named.

The subject of our present chapter, Asplonizm paroulum, is 
not, however, very likely to be looked upon by many eyes, as it is one of the rarest of our native species; being so rare, indeed, that, as far as our knowledge extends, it has never yet been described in any work published in the United States. For this reason we have had to go to a French memoir on the ferns of Mexico for the description which, in accordance with our plan, we have placed at the head of our chapter. The specimens from which our drawing was made were kindly furnished to us by Mr. Jackson Dawson, of the Arnold Arboretum, and came from the southern part of the Alleghany Mountains. Mr. John H. Redfield, of Philadelphia, has found the species on Salt Pond Mountain, in Virginia, and in Carter County, Tennessee. In the latter locality it grows together with Camptosoms rhizo. phyllus, just as Asplenium cbencum often does.

Many good botanists, aware of the great variability of ferns, are disinclined to allow to Asplcuinm parvulum the honor of being a distinct species, and regard it as a mere variety of $A$. cbcncum, or Ebony Spleenwort. In illustration of this variability, it will be noticed that our drawing, which is a very faithful reproduction of nature, differs in some respects from the description of a Mexican form, quoted from the work of Mertens and Galleotti. The fronds in our specimen, for instance, are twice the length given in the description, although this may be accounted for by the different soil which produced the different specimens. In Tennessee our species grows on soapstone rocks, and these may be more congenial to it than the "calcareous and porphyritic rocks in the Eastern Cordilleras" or "the shacly and humid spots" in the environs of Capulalpan and the Haciencla del Carmen, where it is found in Mexico, according to the authors quoted. There are other slight differences, which the reader can easily detect himself, and which are not characteristic enough to be ever regarded as of specific importance. The points of difference between Asplcnizm cbcncum and Asplcnizm paroulum, which strike us most strongly, are principally two. The first of these points is that the veins which diverge from 
the midrib of each pinna (see Fig. 2) do not commence to fork in our species until about half-way between the midrib and the margin, while in $A$. cbencum the forking begins at a point much nearer the midrib; the second is that the sori or fruit-dots, owing to the manner of forking just described, are placed much nearer the margin in $A$. parvulum than in its fellow species, and that they are rounder in the former than in the latter when mature. The specimen from which our drawing was made was young, and our artist scrupulously followed copy; but in some mature specimens in herbariums we have seen the sori almost as round as in some Polypodiums. It is possible, however, that this difference may be due to variation.

The investigation of the specific difference between these two Asplenimms will be particularly interesting to the student, as the question of the limit of species in ferns is exciting a good deal of attention just at present. Some time ago there would have been no hesitation in regarding these ferns as distinct species, but since ferns have become objects of careful garden culture, they have been found to vary as widely from parent types as any flowering plant. A very singular fact also, in regard to ferns, is this, that varieties with remarkably divided, cut, or crested fronds, or with fronds which would be called fasciated, or would be looked upon as monstrosities if we were dealing with flowering plants, are reproduced from spores with almost as much regularity as the parent type from which the variety originally sprung. Formerly a variety was regarded as a mere temporary affair. The test of a true species was that "like must produce like," and the validity of a species was considered as established if from seeds or spores plants could be raised which were like their parents. This is now known to be erroneous. Varieties reproduce themselves.

Explanation of the riate. - 1. $\Lambda$ complete plant. - 2. Magnified pinna, with the sori rather widely apart than crowded. It is well known that this character varies in ail ferns with the fertility. 

VoL. II.

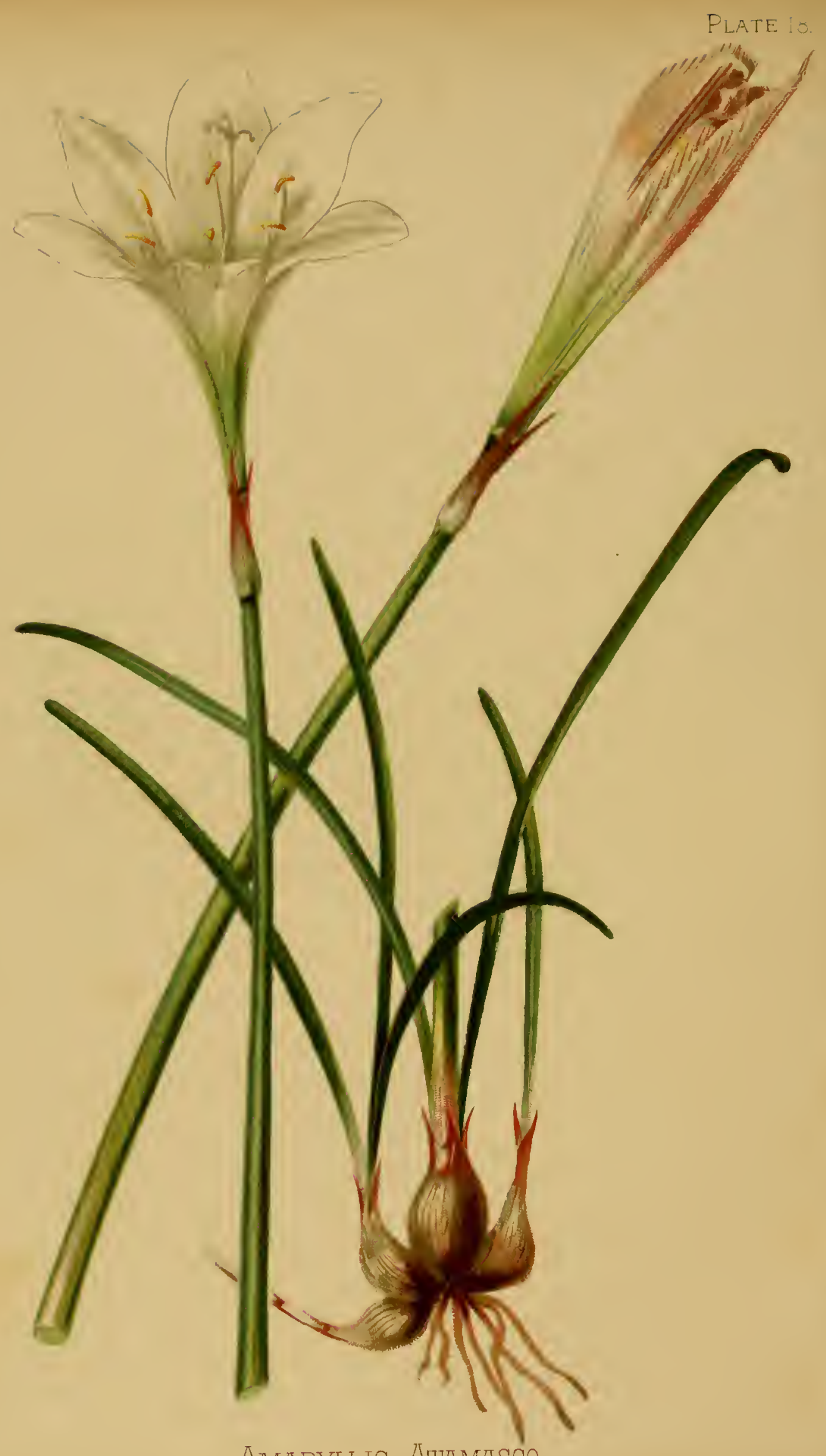

AmARYLLis ÁtTAmAsco. 


\title{
AMARYLLIS ATAMASCO.
}

\author{
ATAMASCO LILY.
}

NATURAL ORDER, AMARILLIDACE.E.

Amarlitis Atamasco, Linnxus. - Scape terete, somcwhat lateral, onc-flowered; leaves linear, concave, dleshy; spathe one-leaved, two-cleft; perianth short-stalked, bell-shaped, white tinged with purple; style longer than the stamens; sceds angled; scape six to twelve inches high, commonly shorter than the glossy leaves; flower two to three inches long. (Chapman's Flori of the Southern Unitud States. Sce Gray's .Mimual of the Botany' of

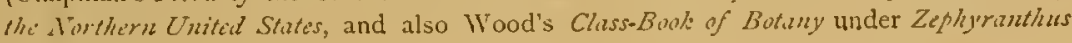
Alamasco.)

S spite of its English common name, the beautiful plant represented on our plate has nothing whatever to do with the Lily family, as this family is now arranged. The name has simply adhered to it because the old botanists erroneously classed it with Lilium, together with so many other plants which have now been removed to other genera. "Atamasco," we are told by Morrison, an early writer, was the name given to our plant by the inhabitants of Carolina, from whence it was first sent to England. The word is in all probability of Indian origin, but we have no linowledge of its precise meaning. Various other names are mentioned besides by other writers. Thus Elliott tells us, in his "Botany of South Carolina," that the plant is called "Stagger-Grass," from a belief widely prevalent that a disease in calves, called the "staggers," is produced by the animals' feeding on it; and Dr. Baldwin, in a letter to Dr. Muhlenberg, published in Darlington's "Memoirs of Baldwin," writes as follows: "March I6, ISI 2, Amaryllis Atamasco in flower. It is the Swamp Lily of the Georgians, and is called 
Toonau by the Creek Indians, who use its bulbous roots as an article of food in time of scarcity."

The genus Amaryllis, with which our plant was classed when its connections with Lilium were severed, was founded by Linnæus in the year 1737 ; but so far as the name is regarded, it is as difficult in this case as it is in so many other cases to say precisely why it was chosen. Amaryllis is a Greek female name, derived from words signifying "splendor." Theocritus, the celebrated Greek bucolic poet, who was born about 300 B. C., gives the name to one of his shepherdesses; and the Roman poet Virgil, who was born in the year 70 B. C., makes a similar use of it. He sings of his return from the city to his country home as of a return to his first love, and personifies the former as a lady named Galatea, who had hitherto bound him fast by her unsatisfactory charms, while the home of his youth is introduced as a beautiful country girl, a shepherdess, - "my Amaryllis." The shepherdess, however, was not so easily won back. She tolerated no divided allegiance, as we may conclude from the following lines translated from Virgil:-

\footnotetext{
"Nor dicl my search for liberty begin

Till my black hairs were changed upon my chin;

Nor Amaryllis would vouchsafe a look

Till Galatea's meaner bonds I broke."
}

That she was justified in this will be admitted by every rightminded person, and it is therefore quite incomprehensible to find writers on emblematic poetry (and lady writers at that, as for instance Mrs. Waterman) endeavoring to associate our flower with "haughtiness" or "pride," in consequence of the behavior of Amaryllis, as related by Virgil. But, however all this may be, and however interesting it may be, it does not help us to a comprehension of the appropriateness of the name as applied to our flower. We shall therefore do well, perhaps, to follow Dr. Gray's lead, and to rest contented with the knowledge that it is "a poetical name." 
The whole genus Amaryllis, indeed, seems to be of a poetical turn of mind; or, to speak more reasonably, seems to have excited the poetic fancy to an unusual degree. One of the species belonging to it has its flowers growing on a slender, curved stem, and therefore, whenever the wind blows, the mouth of the flower turns away from the breeze, as if the coy maiden clesired to escape the kisses of Zephyr, the wild west wind. Dr. Darwin, the author of that curious poem, "The Botanic Garden," refers to this behavior of the plant in the following lines:-

\section{"When heaven's high vault condensing clouds deform, Fair Amaryllis flics the incumbent storm, Seeks with unsteady steps the sheitered vale, And turns her blushing beauties from the gale."}

In our Atamasco Lily, however, there is no such bending of the flowers, no timid or coquettish turning away from Zephyr, and for this reason chiefly the plant was taken from Amaryllis, and transferred to a new genus, Zephyranthes, by Herbert, a modern botanist. But it will be seen that Herbert still adheres to the ancient fancy, for Zephyranthes means "Zephyr Flower," thus implying that, while Amaryllis flies from the advances of her lover, Zephyranthes willingly suffers his embraces, and accepts his lisses.

The erectness of the flowers in the Atamasco Lily is not, however, the only reason which induced Herbert to make the distinction just noted. An additional reason was found by him in the fact that the stamens in our flower are scarcely connected with the perianth, as compared with those of the true Amaryllis; but it is well known that botanists are not generally agreed as to the precise value of differences in a generic character, and the division made by Herbert has not, therefore, been universally adopted. IVe have ourselves followed Dr. Gray, although both Prof. IVood and Prof.Sargent, of the Cambridge Botanic Garden, have accepted Herbert's view. Prof. Sargent, whose plant our artist was kindly permitted to copy, says in a memorandum 
accompanying the drawing: "I think Zcphyranthes is a good genus, and clearly distinct from Amaryllis. It grows in dry ground, and is rather a pine-barren plant. Another form from swamps in Florida, sent by Mrs. Treat, will probably prove a new species, and if so we shall call it Amaryllis Treatc." The common Atamasco Lily, however, grows in low, wet places in South Carolina, according to Elliott, while Dr. Baldwin says of it: "Although most abundant about water-courses, I have seen it on the highest ridges." It is, indeed, in many respects a variable plant. IVe have rarely seen it with such vigorous flowering shoots as those in the specimen which we illustrate, and the color also is often of a much more rosy pink, while the divisions of the perianth are sometimes much narrower. A very curious variation is also noted by a correspondent of the "Bulletin of the Torrey Botanical Club," who saw a specimen growing in the garden of Moore's Hotel, Trenton Falls, N. Y., which had an eight-parted flower-cup or perianth instead of a six-parted one, as usual, and eight stamens with a four-parted stigma. The flower was, in fact, tetramerous instead of trimerous, a very unusual condition in endogens.

When the flowers fade and die, they turn to a much deeper shade. Mr. Rand, in his book on "Bulbs," says, indeed, that "the Atamasco Lily produces rosy flowers, which with age turn pure white," but this statement was probably made on the authority of an earlier edition of an English work, by Green, and $\mathrm{Mr}$. Rand undoubtedly overlooked the fact that in a later edition the error was acknowledged and corrected.

The Atamasco Lily is a very early spring flower, giving great beauty to southern fields and forests in March and April, according to Dr. Chapman. Other authors extend its flowering time somewhat, Prof. IVood saying that in its more nortliern localities it blooms in May, while Dr. Gray even names June. It barely reaches as far north as Pennsylvania by the way of the Blue Mountains, and from that point it extends to the southeast and the southwest, forming in its geographical distribution a triangle, with the Gulf of Mexico as a base. 



\title{
M I M U L US J A M ESI I.
}

\author{
JAMES' MONKEY-FLOWER.
}

NATURAL ORDER, SCROPHOLARIACE.

\begin{abstract}
Mrmulus Jamesit, Torrey and Gray. - Diffuse and creeping, freely rooting, glabrate; leaves roundish and often reniform, from denticulate to nearly entire (four to twclve lines long), all but the uppermost with margined petioles; flowers all axillary and slender pedicelled; corolla light ycllow, four to six lines long; fructiterous calyx campanulate, about thrce lines long; seeds oval, shining, almost smooth. (Gray's Symopfical Flora of Yorth America. See also Gray's Aranual of the Botany of the Northirn United Stutes, and Wood's Cliss. Book of Botuny.)
\end{abstract}

HE plant which our drawing illustrates is a native of the 13. Rocky Mountains, that glorious region to which travellers can now so easily go to spend their summers, and in which so many make botanizing their chief and most delightful occupation. It was frequently met with by the writer of this in his explorations of $s_{7} \mathrm{r}$, being generally found wherever there was a little flat by the banks of a stream, in which the earth could remain wet or muddy during most of the season.

The Mimulus famesii is very variable in size, and is seldom found as luxuriant as the specimen from which our illustration was made, a fact which may be readily seen by comparing the plate with the figures given in Dr. Gray's description. The varying character of the species has maturally led to various views of its specific boundaries, and in times past the plant represented in our drawing would have been regarded as $M i$ mulus Famesii var. Fremontii, a variety which was chiefly characterized by the pedicels or flower-stalks being longer than the leaves. The original species, or the form first found, and named $M$. Famcsii, is thus described by Dr. Gray in his 
"Manual": "Smooth or smoothish; stems creeping at the base; stem-leaves roundish or kidney-shaped, nearly sessile, equalling the peduncles; calyx ovate, inflated in fruit, the upper tooth much the largest. . . . Flowers small, little larger than in the cultivated MI. moschatus or Musk-Plant." Our drawing shows the pedicels a little longer than the leaves; but on the same plant from which this drawing was made there are many pedicels which are not longer, and it is evident, therefore, that this feature is too inconstant to be made the basis for specific distinctions. There is no ground, therefore, for retaining the name Fromontii, even as that of a marked variety.

The size of the flowers also is quite as variable as that of the leaves. Dr. Gray says of the original $M$. Famesie, in the quotation above given from his "Manual," that the flowers are small and little larger than those of the Musk-Plant; and Prof. Porter, in his "Synopsis of the Flora of Colorado," states that it is characteristic of the var. Fremontii to have flowers smaller than the typical $M$. Famesii.

We have gone into these matters of detail because one of the chief objects of our work is to teach general lessons from the special objects before us, and because the present occasion is an excellent one to show the student that even in the best and most accurate descriptions of plants allowance must be made for variations, as Nature does not cast her creations in one unchangeable and rigid mould, but prefers rather to let the various forms glide insensibly from one into the other. If, therefore, at any time the student finds a plant not quite in accordance with the description of the species, it will not of necessity follow that the describer has blundered; nor, if we figure a plant a little larger or a littie smaller, or in some other way a little different from what the observer has seen it, will it follow that the critic is exactly right and our plate is positively wrong. Even the best describers cannot always employ terms that express their meaning absolutely without ambiguity. Take the case of the flowers of our plant, and the terms "small" and "smaller," as 
applied to them. As these terms are used by the various botanists they convey no definite idea of size to the mind of the reader, and Dr. Gray, therefore, tries to define "small" by a comparison of the flowers of $M$. Famesii with those of the MuskPlant. But when we measure the limb of a Musk-Flower, and find it half an inch across, we can hardly realize how the flowers of our species, which are said to be larger than those of the Musk, can be called small. Again, in using the expression "fructiferous calyx," Dr. Gray does not mean to say that the calyx bears the fruit. The calyx is simply permanent, and encloses the fruit or capsule, and this is what Dr. Gray refers to. Some of the half-mature capsules, or rather of the calices which enclose them, are shown in our Fig. 2.

The student will see from these illustrations that he must make allowances, not only for the inperfections of nature, but also for those of language, by which even the best of botanists are occasionally liable to be led into ambiguities of expression, or even actual mistakes.

In its family history the genus Mimuluts has shared the fate of most of the plants which were known before the time of Linneeus, that is to say, it was for a long time without a settled home in the botanic system. It was thrown together with Euphrasia, Lysimachia, and even with Digitalis or Foxglove, until Linneus finally gave it a "local habitation and a name" by calling it Aimulus. This word is derived from the Greek mimo, an ape, and according to the dictionaries our common name "Monkey-Flower" is simply a translation of this botanical appellation. But we have never been able to recognize a resemblance to the face of a monkey in any Mimulus flower that we ever saw, and we are inclined, therefore, to suggest another derivation. Pliny tells us of a plant called Mimmulus, which in his time was a very bad weed in the fields. This weed is supposed by the commentators to have had sced-vessels something like those of the Rhinanthus, a genus which belongs to the same order to which the Monkey-Flower belongs. As the fruit of 
Mimulus is not unlike that of Rhinanthus, it is quite probable that the resemblance suggested the old name to Linnzus, as similar names were suggested to him under similar circumstances in quite a number of cases.

The structure of the Monkey-Flower is very interesting. The stigma is composed of two flat plates which expand, or cven recurve (Fig. 3), when the flower is ready to receive pollen. These expanded plates, when they are touched, close like the leaves of the celebrated "Venus' Fly-Trap." Mr. Kitchener, speaking of the Musk-Plant in the London "Journal of Botany" for 1872 , regards this arrangement as a device to prevent self-fertilization. The bee on entering is supposed to bring foreign pollen to the stigma, which latter then closes, so that the flower's own pollen cannot be deposited on it as the insect withdraws. But in all the observations made by the writer of this the motion was found to be so slow that the plates of the stigma never closed entirely before the bee had left the flower.

The sced-vessel of our species, seen in section, is a very beautiful object, owing to the peculiar construction of the axile placenta, and the manner in which the seeds are attached to them. We give an outline drawing of such a section in Fig. 4 . The construction of these placentre varies in the several species belonging to the genus Mimulus, but it is always worth examining.

The geographical range of James' Monkey-Flower is given in Dr. Gray's "Synoptical Flora of North America" as extending "from Illinois to upper Michigan and Minnesota, and west to the Rocky Mountains in Montana, and then south to New Mexico and Arizona."

Explanation of the Plate. - I. A young and vigorous plant at its first flowering. - 2. A seed-bearing branchlet late in the season. $-3 \Lambda$ young seed-vessel, with the style and its divided stigma. - 4. Cross-section of a mature seed-vessel. 
(1) 



\title{
BRODIAA GRANDIFLORA.
}

\author{
I.ARGE-FLOWERED CALIFORNIA IIYACINTII.
}

NATURAI, ORDER, I.ILIACE.\%.

Brodita Grandfror., Smith. - Dulb depressed glubose, fibrous conted; pedicels stout, divaricate, then at length erect ; flowers four to cight, rarely but one; the inmer segments nearly twice broader than the outer, all spreading aluve. Sterile stamens usually longer tha: the firtile, cmarginate, yellowish. (Prof. Wood in Procedings of the Academy of Niturit Siences of Philudelphia for IS6S. See also Watson's Botany of Clarence King's Expitition. belong to the Pacific coast, and have been under cultivation for some years. They are generally known as "California Hyacinths," and although they really have not much in common with the true Hyacinth, they and their neighbors of the genus Lcucoryne come perhaps as near to these celebrated fiowers as any of the plants indigenous to the United States. One of the most striking marks of distinction in these two genera of plants is to be found in the inflorescence; for while that of the Hyacinths is racemose or spicate, the flowers of the Brodica are collected in an umbel. This difference, however, would hardly be regarded as of generic value by a systematic botanist; but a close analysis will reveal differences which are much more essential. In the Hyacinth, for instance, the perianth is campanulate, while in the Brodiac it is mostly tubular, or funmel-shaped. The seed-vessel also has peculiar characteristics in each; but one of the most striking differences is observable in the stamens, which are six in the Hyacinth and only three in Brodica. Six stamens, indeed, is the normal condition in the Liliacea, but in Brodiaa 
and some of its allics three of the six leaves which should have been transformed into stamens have been but imperfectly developed, and are left in a subpetaloid condition. These sterile or petaloid stamens are well shown in the flower marked Fig. 5 on our plate, and can also be noticed in the flower in a horizontal position to the left of Fig. 5 .

The student will find it well worth while to compare the flowers of the genus Brodiaa with those of other allied orders, as such a comparison will clearly show that the differences, seemingly so great, between the various families of plants, are often due simply to greater or less arrest or acceleration of the growth-waves which form the verticils. Endogenous plants, to which great division the Liliacce belong, have their growthcycles in threes; but the two verticils, which in other plants form the calyx and the corolla, are arrested in such quick succession in the Liliacce that they are both almost equally developed. It is, therefore, scarcely possible to distinguish between them, and hence both are looked upon as one structure, so that, in the case of a Lily, we do not speak of three sepals and three petals, but simply of a six-parted perianth or flower-cup. But if we examine an Alisma, or a Tradcscantia, as types of two natural orders closely allied to the Liliacca, we shall find that each verticil has been acted on by a separate growth-wave, and that the differentiation of the two verticils has been sufficiently great to produce a perianth in which the calycine and the petaloid divisions can be readily noticed. Returning to the Liliacec, and proceeding to study the development of the verticils following those which produced the perianth, we shall again perceive that two sets of leaves of three each have been caught quite or nearly by the same growth-wave, and have been converted into six stamens. In most of the genera of the order these stamens are almost alike; but in Brodica the lower, or first of the two staminate verticils has evidently been caught by the wave which formed the perianth, and thus it has assumed the form of the sterile petaloid processes which we have before alluded to (see 
Fig. 5), while the second verticil has been developed into three perfect stamens. In this manner the structure of the flowers of the Lily family supplies an excellent illustration of the influence of rhythmical growth on the evolution of form.

The three staminoid petals (or petaloid stamens) are apparently on a line with the perfect stamens, but with a little care in observation it can readily be seen that they are placed somewhat lower, and when the flower is examined before opening they will be found to form what some authors have described as an involucre around the base of the real stamens.

The wavy growth of the leaves in our species is also well worth noting, because it will be found that the same peculiarity has been acquired, or exists, in the flower-stalks or stems of other species of the same genus. This fact seems to support the morphological doctrine that the stams are but modifications of the leaves, as it is not likely that the same tendency would be noticeable in both if the stems and leaves were not produced simply by the modification of the same elements.

The Brodiaa srandiflora was the first known of the species of its genus, having been discovered nearly one hundred years ago (in I 792) by Menzies, a Scotch collector. It was named by Sir J. E. Smith, the president of the Linnean Society of London, in honor of James Brodic, another Scotch botanist, who was particularly distingruished for his knowledge of cryptogamous plants. Brodic, howerer, was not connected with our plant in any special manner, as he was not its discoverer, and even had little to do with American botany, as far as we are aware of. After its discovery by Menzies our flower seems to have been lost sight of by botanists, until it was again found by Lewis and Clarke's expedition to the Missouri and Columbia Rivers. Some years after this expedition it was also found by Douglas and Scouler near Fort Vancouver, and bulbs scnt home from there by Douglas bloomed in England in $1 S \_S$. Up to the time just named it was the only known species of its genus, all the other species described in modern botanical works having been found subse- 
quently. In its native places of growth it is said to prefer dry, open plains, and in favorable situations it is often found in such abundance that it presents a beautiful sheet of blue in May, which is its flowering time. It is found chiefly in Washington Territory and Oregon, and occurs eastward to Utah in the shape of a variety which connects it closely with an allied species.

We are at a loss to know what common name to bestow on this flower. We have before stated that it is sometimes called "California Hyacinth," in company with several other species of the same genus, and we may add that one of these species is known as "Satin Flower." It seems quite probable, however, that the first of these names will finally prevail, and we have therefore called our species the "Large-Flowered California Hyacinth," although with some reluctance, for we have shown on a previous page that "Hyacinth" is hardly appropriate for our flower, and a similar objection might be raised against the specific name. At the time when our plant was named, the epithet "large-flowered" might have done very well, but since then other species of the same genus have been discovered, which may well claim that they have as good a right to this designation as the present species.

Dr. Torrey and other botanists report that several varieties of our flower are found in a wild state, and it is quite likely that the Brodica grandiflora might rival the Hyacinth in this respect, both in form and in color, if skilful cultivators should take it in hand.

Explanation of the Plate. - I. Complete plant, with root-leaves and flower. - 2. Ovarium. - 3. Cross-section of ovarium. - 4. Sced-vessel. - 5. Flower showing the three petaloid stamens around the perfect ones. 
(2)
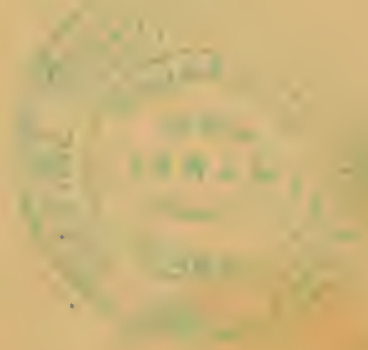


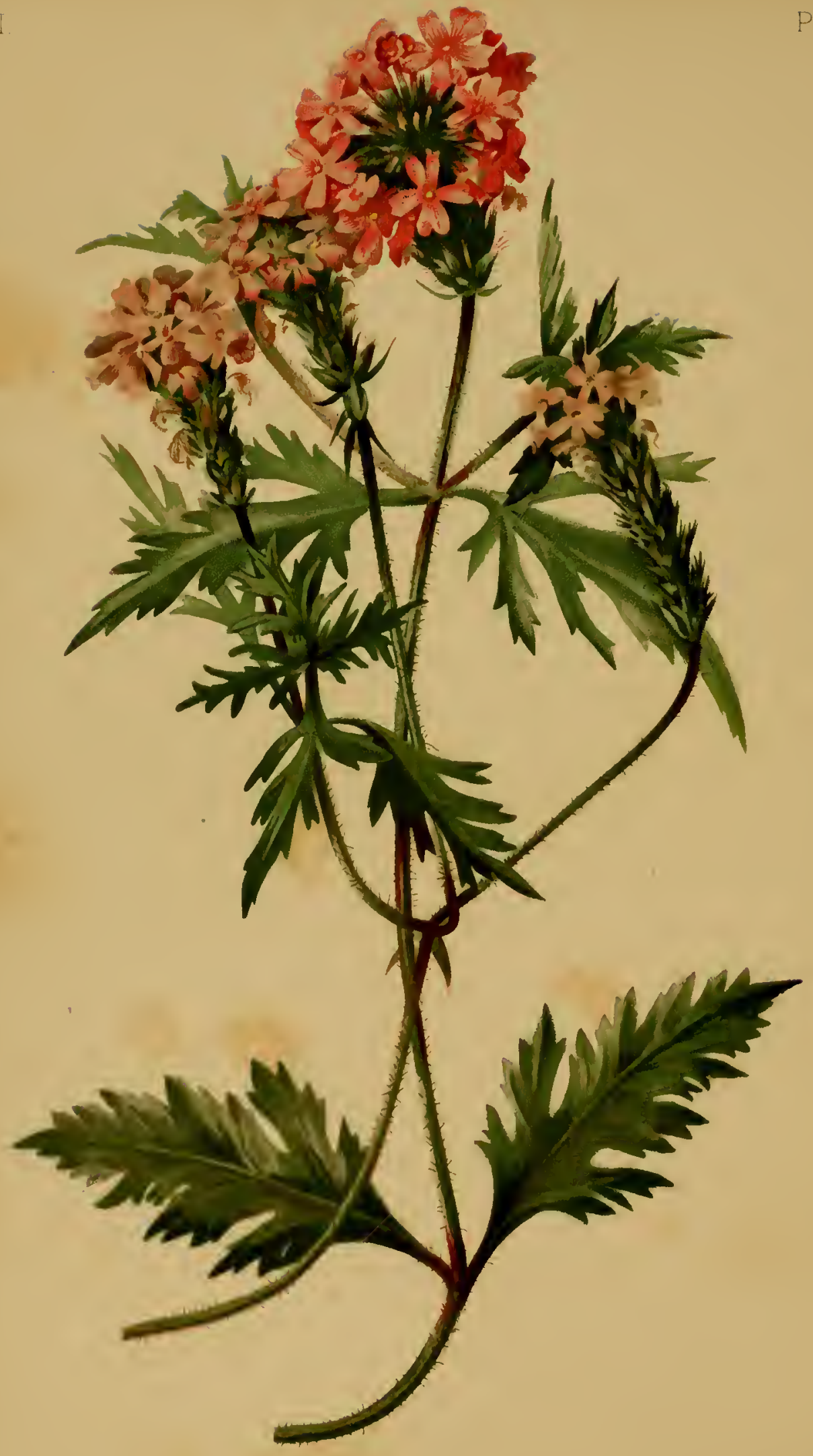

Plate 21

VOL II 


\title{
VERBENA A UBI.ETIA.
}

\author{
AUBLET'S VERBENA.
}

NATURAL, (RDLK, YKRBENACEAL.

\begin{abstract}
VERBENi AUnLetiA, Linnæus - Hairy; stem creeping at the base, ascending, forking; leaves orate-oblong, three-cleft, with the lobes toothed, narrowed into a slender petiole; the Jower ones smaller, rounded, tuothed; spikes terminal and in the forks of the stem, longpeduncled, closely flowered; calyx long, slender, the unequal teeth subulate; corolla showy, purple; stem six to twelve inches high; corolla one half inch long. (Chapman's Flora of the Southern [nited States. See also Gray's Mumul of the Botuny of the Northern ('uiled State's, and Wood's Class-Book of Botany.)
\end{abstract}

592. INNÆUS tells us that "Verbena is a Latin name of 20.0 uncertain derivation," and Dr. Gray, in his "Manual," says it is "the Latin name for any sacred herb; derivation obscure." Furthermore, Caspar Bauhin, who wrote in I596, says that the plant is referred to by Dioscorides, a Greek physician who lived in the first century of our era, as the "sacred herb," that it had leaves like the oak, and that it was used as an amulet and in expiatory exercises; and Sibthorp, in his "Flora Greca,"

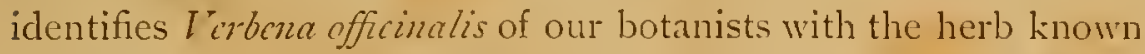
to the ancients. The Greeks employed the leaves of the plant to cleanse the table used in the festivities celebrated in honor of Zeus (the Jupiter of the Romans), and for this reason it was looked upon as the great sacred cleansing herb. Some authors have, therefore, conjectured that Vorbcua might have been derived from verro, to brush or to clean. Others, however, are inclined to think that the name must have come from herba, an herb.

The name appears to have been given to several plants by the Romans, and the uses they macle of these plants were 
manifold. Thus Virgil in his eighth Eclogue, as translated by Dryden, mentions the name in connection with a kind of lovespell, or conjuration:-

"Bring running water, bind those altars round

With fillets, and with Vervain strew the ground;

Make fat with frankincense the sacred fires,

To re-inflame my Daphnis with desires."

At the festivals of Venus Victrix, at which myrtle, bay, and similar aromatic herbs were used to make wreaths for the conqueror, the Verbena was also occasionally used; and its sacred character was likewise recognized in the practice of sending a small portion of the herb as a New Year's present to fricnds.

The English name, Vervain, is said to be from the old Celtic forfacn, the meaning of which also refers to the cleansing or removing power attributed to the plant by the Greeks.

Our present specics, Verbcna Aublctia, received its specific name in honor of Jean Baptiste Fusée Aublet, a botanist of considerable note, born at Salon, in Provence, in the year I 723 . Aublet collected especially in the Mauritius, and published a history of the plants of French Guinea in 1775 . Three years after this datc he died in Paris. It is a curious fact that quite a number of botanists sought to honor Aublet by naming a genus after him, and that all these attempts failed. Gærtner's Aublctia proved to be a Sonncralia, a myrtaceous plant; Louvier's Aubletia is Paliums, the Christ's Thorn; that of Richard is Monnicria, a genus of the Rue Family; and that of Schreber was found to belong to Apciba, a genus established by Aublct himself. Even the plant to which this article is devoted was made into a separate genus by Jacquin, but had to be remanded to $\mathrm{V} c r b c n a$. It is rare that so many attempts to honor a botanist have come to naught. These repeated endeavors show the esteem in which Aublet was held by his colaborcrs, and it is at least a consolation to know that his name is likely to endure for a long time in the specific appellation of our plant; for the 
I'crbena Aubletia being such a beautiful plant, Aublet's connection with it may, indeed, secure for him a wider fame and a more extended knowledge of his works, than if his name had been coupled with some obscure and less attractive genus.

Aublet's Verbena has few equals as a beautiful object in flower-gardens. It does not, indeed, come up to the Brazilian varieties, now so well known as Verbenas to the florists, in delicacy of growth, and in brilliancy and rarity of color; but it may be a question whether it might not be much improved, so far as color and form are concerned, under proper care. The "Botanical Magazine," of London, says it was introduced into Europe by M. Richard, in 1774 , and goes on to state that it "flowers in June and July. The extreme brilliancy of its color renders it a very ornamental green-house plant." This last remark sounds rather curious to American ears, as the plant is very hardy with us, and does not need the protection of the green-house.

Before the variable character of our Verbena was so well known as it is now, the varieties found were thought to be species, and were given new names. Thus we find $I$. bipinnatifuda, $V$. glandulosa, $V$. montana, and some others named in botanical works; but all these designations have been abandoned, as the plants which bore them are now looked upon as identical with $V$. Aublctic. The number of real species of Verbena is, indeed, large enough, without naming so many mere varieties. When Tournefort enumerated the species of this genus in the year 1700 , the list comprised only seven; but in $18_{47}$ De Candolle brought together eighty-five.

In poetry the Verbena seems almost unanimously to be considered the emblem of sensibility, but on what ground we have been unable to determine. If Moore's lines,

"The heart that is soonest awake to the flowers Is always the first to be touched by the thorns,"

be accepted as a good exposition of the idea of sensibility, then surely there is nothing in the Verbena to suggest it. There is 
an old legend about the Verbena, which might, perhaps, lead us to think that the plant itself was supposed to be sensible to the sufferings of others. An old writer tells us that the herb is used for healing wounds, and says: "When they gather it for this purpose, firste they crosse the herb with their hand, and then they blesse it thus:-

"Hallowed be thou, Vervein, As thou growest on the ground, For on the Mount of Calvary, There thou wast first found.

Thou healedst our Saviour, Jesus Christ, And staunchedst his bleeding wound;

In the name of the Father, Son, and Holy Ghost, I take thee from the ground."

An American poet imagines that the flower itself is suggestive of the idea :-

"Verbena, in thy pensive grace

The emblem of the feeling heart I trace," -

but this couplet was probably inspired by some species more slender flowered than Aublet's.

Our plant seems to have its northern limit about on the line of Central Illinois, Central Missouri, and Central Kansas, whence it is found southerly to the Gulf of Mexico. It grows at the foot of the Rocky Míountains, near Denver, and has been found in the Mojave Valley of the Colorado, but has not reached the Pacific coast. Its central home seems to be about in Texas and Arkansas. It is reported from Southwestern Pennsylvania, but northward of that state it is probably not found east of the Ohio River. It flowers in May or June, and continues till frost. 



\title{
HYPOXIS ERECTA.
}

\author{
STAR-GंRASS.
}

NATURAL ORDER, AHARYLLIDACEE.

\begin{abstract}
IlYoxis ERECTA, Linneus. - Pilous; scape about four-flowered, shorter than the linearlanceolate leaves. Leaves all radical, six to twelve inches by three to five lines, acute. The slender, hairy scapes, several from the same root, arise six to eight inches, divided at top into a sort of umbel with three to five pedincles, having eacis a minute, subulate spathe at the base. Perianth hairy and greenish without, jellow within; segments oval, rather obtuse. (Wood's Class.Book of Botuny. See also Cray's Mrumual of the Botuny of the Northern United States, and Chapman's Flora of the Southern United Stutes.)
\end{abstract}

HE beautiful little plant to which the present chapter is (5) devoted is one of the oldest known of our native flowers, as it was included in the eatalorne of the flora of Virginia, whieh the Rev. John Bamister sent to Ray, the well-known English botanist, towards the end of the seventeenth century. It was then thought to be an Ornithogalum, a genus belonging to the neighboring order of Liliacce, and was so styled by Clayton when he sent his specimens to Gronovius in the earlier part of the succeeding century. We first meet with it, separated from Ornithogalum, and as Hypoxis, in Schreber's edition of the "Genera Plantarum" of Linneus. The shape of the seed-vessel or capsule, which is narrowed at the base, seems to have been chiefly relied on as characteristic in giving the plant its new name, - Hypoxis being from the Greek hy'po, under, and orys, sharp, and signifying, therefore, "sharp or tapering underneath." This later name is certainly an improvement over the older one, as we know at least how it is clerived, which is more than can be said of Omithogalum. In the Greek form of Omithogalon. this name occurs chiefly in the vritings of Dioscorides, a Greek 
physician, who flourished about the year 60 of our era; and it will be admitted that the name is far from being clear, and leaves room for guessing, when it is considered that its literal meaning is "bird's milk," - a very strange fluid, no doubt, and difficult to connect with anything relating to a flower. Very naturally this curious name has given rise to a good deal of speculation, and an old French writer, Louis Liger d'Auxerre, tries his hand at the enigma as follows: "If we inspect the etymology of Ornithogalon we will find that it signifies lac gallina, or hen's milk. It must be only in raillery by supposing that hens gather milk by eating of the leaves of this plant. But our better way will be to believe with Marcellus, who tells us it was so called from the whiteness of its flowers, which resembles the whiteness of milk." This, of course, refers to the true Ornithogalum, the flowers of which are white, while those of the genus Hypoxis are all yellow. There is also an ancient fable connected with the name, which may interest, and which we therefore give the reader. According to this fable, Ornithogalon was the son of Afros, and of Ania, his wife. This couple lost all of their six children, with the exception of Ornithogalon, who, in consequence, was petted and spoiled. Hardly anything was good enough to feed him on, and the chief dainty for him was a "milk which appeared round the yolk of a lightly boiled egg," the yolk being rejected for fear of overloading his delicate stomach. Nothing, indeed, was thought of but cooking for him, and his education and future prospects were entirely neglected. But at last the parents died and left no estate, and poor Ornithogalon, not having the means to live as he had been accustomed, pined away, and soon followed his father and mother to the grave, when he was turned by the gods to a flower.

The true Ornithogalum is the pretty little white flower, well known as the "Star of Bethlehem." In the earlier times the Hypoxis erecta was sometimes called "Yellow Star of Bethlehem," or, as Barton has it, "Yellow Bethlehem-Star "; but at present its generally received common name is "Star-Grass." 
All the members of the genus Hypoxis have yellow flowers, and there are numerous representatives in the great home of the genus in Southern Africa, while there are probably but two good species in the United States. The relation of our plant with so many others in that distant part of the world is an interesting fact for those who may be engaged in the study of botanical geography.

We have seen that modern botanists have separated the genus Hypoxis from its original relations in the order Liliacer. But some investigators have gone even further than this, and have thought it necessary to place the genus in a separate order, of which they have made it the type. While most of our American botanists place it in the order of Amaryllidacia, Dr. Lindley, in his "Vegetable Kingdom," classes it as Hypoxidacce ; but Dr. Lindley himself notes that there is little, beyond the general habit of the plants, to distinguish this order from the order of Amaryllidaces, this little being that the radicle or growing point in the seeds of Hypoxidacca is near the hilum, that is to say, near the place where the seed is connected with its parent; while in the Amaryllidacca, as he views them, the radicle is on the opposite side.

The reader has noted that the tapering base of the capsule suggested the name of the genus, but the opportunity of examining this capsule seems to be rather rare. The writer of this never saw a perfect one till August, is 8 , and the specimen then found is given in our plate (Fig. 2). It is very small, and wholly enveloped by the persistent sepals, but on being opened it will be found to contain the little black seeds. Dr. Darlington seemis to have had a similar experience to that of the writer of this, without his final good fortune, for in his "Flora Cestrica," or Flora of Chester County, Pennsylvania, he says: "I think this plant rarely perfects its fruit. Common as it is, and familiar as I have been with it for half a century, I have never observed a full-grown capsule." It may be that the plant, having perhaps wandered a long way from its original central home, 
which appears to be Africa, judging by the numerous species growing there, has found a limit to its power of extension, and produces seeds rarely, or in those parts of our country only which are most favorable to its original requirements. In the absence of seeds it would have to multiply chiefly by offsets; but the exact manner of their growth requires further observation. The main plant increases by slow additions at the apex, the under portion dying every year, as shown in our plate, where the rootless portion of the base represents the decaying part. As in time, from its erect position, the apex must necessarily rise up to the surface of the ground, it is probable that the main plant dies when this point is reached, and that the race is then continued by the younger offspring.

The Star-Grass is in flower in Nay, according to some authors, and in June, according to others. But in Germantown, Pa., it blossoms from Mlay to September. It is found in all the states on the eastern slope of the continent, from Maine to Florida. In Kansas and Arkansas it is quite common; and it was also found by Marcy's expedition on the head waters of the Trinity River, in Northern Texas. It doe's not, however, seem to have reached Colorado, nor is it found in Wyoming or Idaho, and it is probably wholly confined to the regions east of the Rocky Mountains. Its northwestern limit is Minnesota, where it is abundant.

The favorite places of growth of this species seem to be open woods, or waste places covered with low shrubs; but our specimen is from a cranberry swamp, and it may have been that this position favored the production of seed.

Explanations of the Plate. - 1. Complete plant. - 2. Mature capsule with seed.3. Anther much enlarged. 



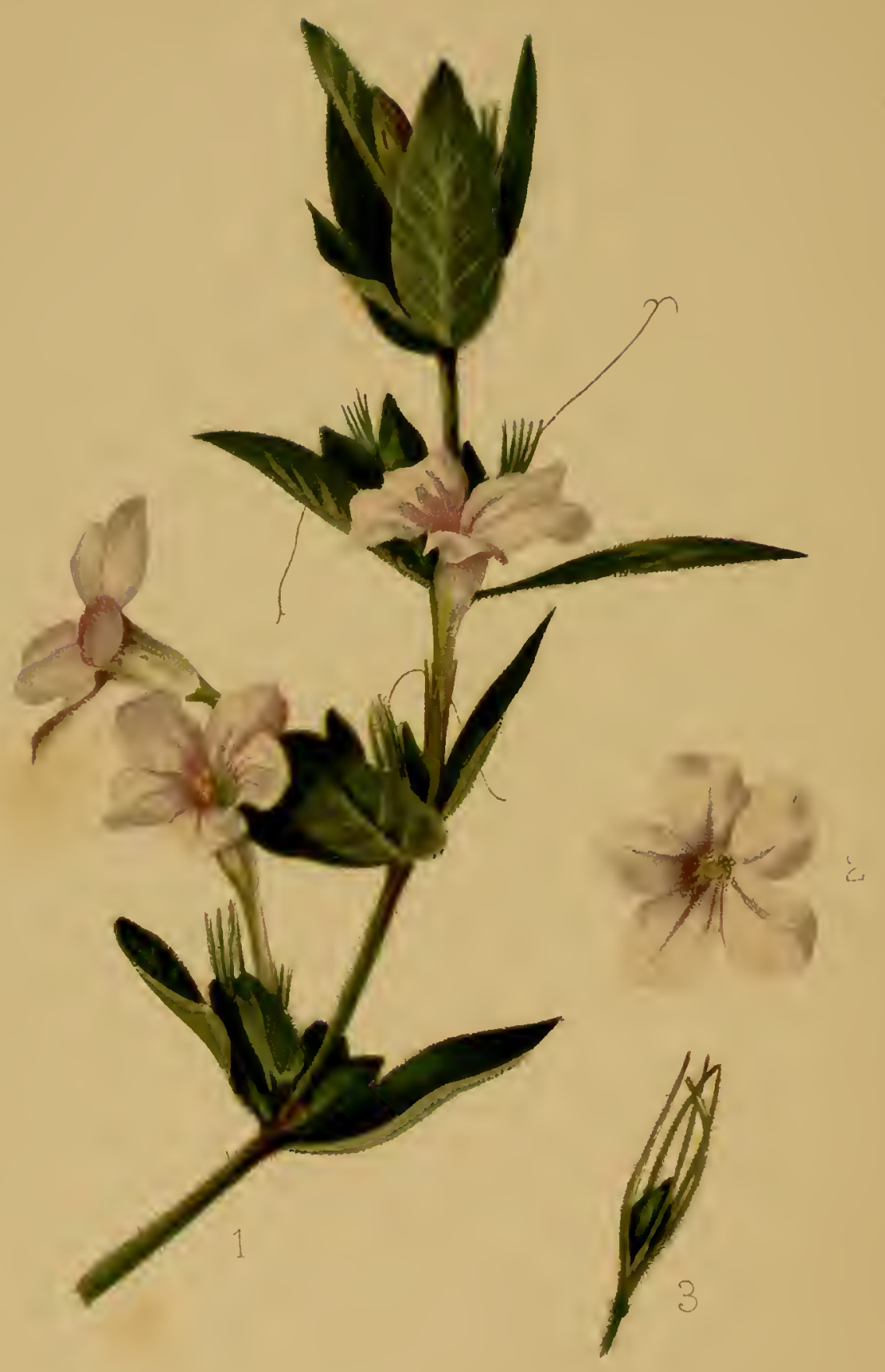




\author{
RUELLIA CILIOSA. \\ I. ONG-T UBED R LELLIA. \\ N.ITUKAL, ORIER, ACANTHACLA:
}

\begin{abstract}
Ruellol. cilios., Pursh. - Hirsute, with soft whitish hairs (one foot to three feet high); leaves neariy sessilc, uval or ovate-oblong (one inch to two inches long); flowers one to three and a!mont sessile in the axili; tube of the corolla fone inch to one and one half inches long) fully twice the length of the setaceous calyx-lobes; the throat short. (Gray's Munual of the Botuny of the tionthern ('nited Stutes. Siee also, under Dipleracunthus cilioszes, Wood's Cliss-Book of Botrny, and Chapman's Flori of the Sonthern United Shites.)
\end{abstract} belongs is historically interesting, as it is derived from the Acanthus, so well known in connection with the Corinthian order of architecture. The legend of the invention of the Corinthian capital varies somewhat as it is told by different writers. The most pathetic version is given as follows by Fanny Osgood: "It is said that the architect Callimach, passing near the tomb of a young maiden who had died a few days before the time appointed for her nuptials, moved by tenderness and pity, approached to scatter some flowers upon her tomb. Another tribute to her memory had preceded his. Her nurse had collected the flowers which should have decked her on her weddingday, and putting them with the marriage veil in a little basket, had placed it on the grave near a plant of Acanthus, and then covered it with a tile. In the succeeding spring the leaves of the Acanthus grew around the basket; but being stayed in their growth by the projecting tile they recoiled, and surmounted its extremities. Callimach, surprised at this rural decoration, which scemed the work of the Graces in tears, conceived the capital of 
the Corinthian column, a magnificent ornament still used and admired by the whole civilized world." The story is quite attractive, no doubt, but like so many other poetical fancies, it has been attacked by the critics, and its reliability impeached. Its poetical reality, however, still survives; and whether it be true or apocryphal, we may learn from it the lesson that many beautiful aids in the study of nature and of art are to be found all around us, if we will only look about us with attentive eyes. There are plenty of materials among our native plants for forming combinations that might become as famous in after ages as the invention ascribed to Callimachus.

Those who are acquainted with the various forms of the Acanthus-leaf employed in Greek and Roman ornamentation will possibly wonder why the plant represented on our plate should belong to the same family. There is certainly very little resemblance between the bold, deeply cut leaves of the Acanthus and the entire, lanceolate leaves of the Rucllia ciliosa; but the leaves alone are very subordinate in fixing the characters of an order. It is the flowers, and especially the fruit, which settle the question; and in these particulars our plant agrees with the other members of the order, although within the order itself it is widely removed from the real Acanthus.

The order of Acanthacce is very closely related to that of the Bignoniacce, to which the common Trumpet-vine and the Catalpa belong. The flowers in both are similar in form, and the two-lipped stigma is in some genera very nearly alike in the two orders. The two-valved capsule is also common to both, and the elementary plan of the flowers is very nearly the same. But in Acanthacca there is a general tendency to flower from the axils of the leaves, while in Bignoniacca the flowers rather terminate the growing shoots. One of the leading characters, however, which botanists rely on in clistinguishing the two orders, is found in the woody, hooked beaks by which the seeds are at. tached to the placenta (or surface on which they are borne) in the Acanthacca, a peculiarity which is not found in the Bignoniacea. 
It is evident, from what we have just said, that it is rather difficult to define the order to which our plant belongs. This is true also of the genera, and botanists therefore differ somewhat in regard to the genus of some of the species. According to Nees von Esenbeck, the great authority on Acanthacce, the Rucllias ought to be classed with Dipteracanthus, a genus created by the botanist just named. Prof. Wood and Dr. Chapman still adopt this arrangement; but Dr. Gray, although formerly an adherent of Nees von Esenbeck's views in this matter, classes our plants as Rucllias, and in this we have followed him.

The genus was named Rucllia in honor of one Ruelle, who is said to have been an old French herbalist. The specific name of our species, ciliosa, which was given to it by Pursh, the discoverer of the plant, is from cilium, an eyelash, in allusion to the hairy character of the stem and leaves. The Rucllic ciliosa has no common name that we are aware of, and the most natural proceeding would therefore seem to be to use a translation of the botanical appellation as an English name. But we have preferred to call our flower the "Long-tubed Ruellia," as the extremely long tube of the corolla is more characteristic than the hairiness of the stem and leaves. There is, besides, an Asiatic species, Rucllia ciliata, the name of which, translated into English, would be identical with that of our own plant.

Very little is known of the properties and uses of the Rucllia ciliosa, but it is quite possible that it may yet be found of some value to man. The roots of an allied species, found in Texas, are used by the Indians in fevers; and an East Indian species yields a dye. One of the most celebrated blue dyes of China, known as Tien-Ching, is also the product of a Rucllia, which, according to $\mathrm{Mr}$. Fortune, the traveller, is grown in immense quantities by the Chinese. The plants are cut before the flowers appear, and are thrown into tubs containing water, in which they are allowed to rot for three or four days; after the plants have been taken out with rakes, lime is added to the water, and the sediment which forms in the course of three or four days is 
the dye-stuff. Mr. Darwin believes that some of the plants belonging to the order of Acanthacce are especially adapted to cross-fertilization. On the other hand, the next-door neighbor of our species, $R$. strepcns, often bears cleistogene flowers, or, in other words, flowers which mature in the unopened bud, and which are, therefore, absolute self-fertilizers.

The flowers of the Long-tubed Ruellia are very beautiful. They are, however, said to be very fugaceous, each one lasting only for a day; but if this be correct in all cases, they must be produced daily in great abundance. Our species commences to bloom in June, and continues till September, and there is scarcely a day within this period that the student may not find flowers for examination. The writer of this saw the plant growing in Tennessee in the middle of August, covering dry and exposed banks with a mass of blossoms, and producing a truly beautiful spectacle, such as could hardly be excelled by any other of the wild flowers of that region.

The order to which the Rucllia belongs, being chiefly a tropi. cal one, is represented by comparatively but few species in the United States. Our Long-tubed Ruellia is rather circumscribed in its geographical distribution. According to Dr. Gray it is found in "dry soil, Michigan to Illinois and southward "; Prof. Wood locates it in "rich soils, Western and Southern States"; and Dr. Chapman says it grows in "dry soil, Georgia, Savannah, and westward." Its most natural home seems to be west of the Alleghanies; and it is common in Indiana, Ohio, Michigan, and Nebraska. It passes south through Kansas and Missouri, but has not, to our knowledge, been found in Arkansas or the Indian Territory.

The specimen from which our drawing was made grew in the Botanic Garden of Harvard University, at Cambridge, Mass. 



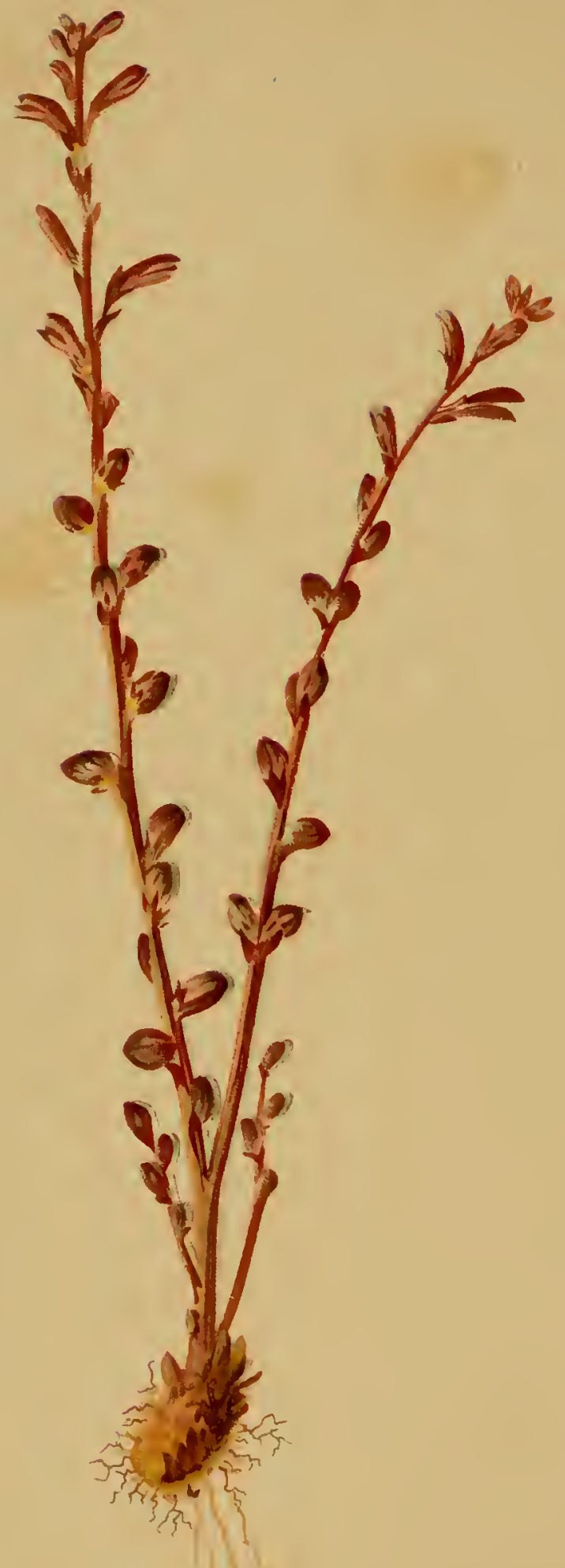




\title{
EPIPHEGUS VIRGINIANA.
}

\author{
BEECH-DROPS.
}

NATUKAL (MRJEK, (IROMANT'IACF.E.

Eprateris Vikiniana, liarton. - Annual, slender, a fuot or so high, with thickened base, producing short, fibrous, matted roots, glabrous, dull purple or yellowish-brown, paniculatcly branched; scales and bracts minute and sparse; cleistogamous flowers a line, and capsules two lines long; developed corolliferous flowers along the upper part of the branches three to six lines Jong, purplish and whitish. (Gray's Syuoptial Flour of Jirth

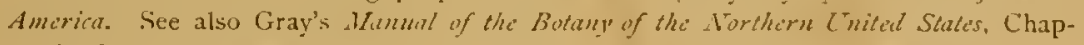
man's Flora of the Southern United Situtes, and Wood's Cliss-Booliof Botany.)

PIPHEGUS VIRGINIANA is one of those strange plants which are supposed to feed on the vital sap of other organisms. The whole of the order Orobanchacer, to which the plant belongs, is, indeed, composed of these vegetable vampires. It received its name from the genus Orobanchc, of which we have no indigenous representative in the United States. That the peculiar habits of these plants were already well known to the ancients, is evident from the old Greek name Orobanche, which occurs in several classical authors, and signifies "a strangler of vetches." The oldest known species in England was called "Broom-Rape," because it was supposed to grow mainly on the roots of the broom, and Dr. Lindley, therefore, designated the whole order as the "Broom-Rape Family."

In explanation of this common name, Dr. Prior, the accepted authority on the popular names of British plants, tells us that it comes from "broom, a plant, upon which it is parasitic, and rape (Latin, rapa), a turnip, which its clubby, tuberous stem somewhat resembles." But there is no English species with a thickened stem having any very striking resemblance to a turnip. The base 
of the stem in the English Broom-Rapes is about the size of a large marble, and scaly like a lily-root. It is far more likely that the word "rape" refers to the parasitic habits of the plant. Formerly this word had a much wider significance than at present. "To commit rape" and "to commit robbery" were interchangeable terms, and it is quite natural, therefore, that a plant which makes its living by rapine on the broom should be called the "Broom-Rape."

Epiphegus Virginiana was among the earliest known of American plants, and is to be found under various names in the works of Walter, Gronovius, Morrison, and others of the older botanists. It was, however, thought to be a true Orobanche, and the authors just named, and even Linneus himself, called it Orobanche Virginiana. Nuttall was the first to point out the differences which separate our species from Orobanche, and in his "Genera," published in 1818 , he described it under the name of Epifagus. It is not often that Nuttall gives his reasons for the names selected by him, but in the present case he has departed from his usual custom. Epifagus, he tells us, is "nearly similar to its (i.c., the plant's) common and appropriate name of 'Beech-Drops,' by which this plant is universally known, from being commonly parasitic upon the roots of the beech, Fagus syluatica and $F$. formsinza." Epi being Greek for "upon," and fagus Latin for "beech," the meaning of the name is obvious enough. It has, therefore, been retained by succeeding botanists, but the last constituent of the compound has been changed to its Greek form phegus, as it is not considered proper in botany to coin one name from words belonging to two different languages. Nuttall called our species Epiphcgus Amcricanus, while Barton, in his "Compendium of the Flora of Philadelphia," which appeared almost simultaneously with Nuttall's "Genera," called it E. Virginiana. Barton's name has been adopted by most American botanists, as it is more in accordance with the name by which the plant was previously known. 
Our plant, although it belongs to a parasitic family, and undoubtedly has parasitic habits itself, is yet not wholly dependent upon robbery for its subsistence, as any one can see who will carefully dig and examiné its roots. It has innumerable fibres by which it draws sustenance directly from the earth. The exact manner of germination of the Epiphcgus Virginima is not yet known, but that of some of the European Broom-Rapes has been ascertained. The seeds usually sprout when in contact with the growing point of a victimized root. In the case of the Epiphegus, however, the writer has found a stolon-like thread at the lower end of the succulent base of the mature plant, which seemed to make it evident that the plant had been connected by that thread at a former period of its life with the root of some other plant below it. It is probable, therefore, that the plant is parasitic in its early life, and becomes self-sustaining at a later age.

A remarkably interesting feature of the Beech-Drops is to be found in the cleistogene character of some of their flowers. These cleistogene flowers, which grow on the lower part of the stem, produce seeds without ever opening, so that they are of course compelled to fertilize themselves by their own pollen. The flowers towards the ends of the branches open regularly like other flowers, and are in every way perfect, being provided with both pistils and stamens, and yet, strange to say, they have never been known to produce seed. This is especially interesting in view of the prevailing theories relating to the advantages of cross-fertilization. It is believed by many of the leading scientific men of our day that all plants were originally selffertilizing, and adapted themselves to cross-fertilization only after the appearance on earth of the winged insects, which are necessary, in the case of what are known as the entomophilous class of flowers, to effect the transmission of pollen from one flower to another. There are other botanists, however, who hold different.views. Thus the editor of the "Bulletin of the Torrey Botanical Club" (Vol. VI, p. 65), speaking of Epiphegus 
Virginiana, regards the upper petaloid, or complete opening flowers, which according to the theory first mentioned ought to be useful in cross-fertilization, as "having lost their usefulness to the plant." If this view be accepted, it follows, of course, that self-fertilization is the latest, and not the earliest condition, although, as the author remarks, "in accordance with theory, self-fertilization should at length produce feebler forms." The same author thinks that possibly the plant may be tri-morphic, or in other words, that it may have three distinct classes of flowers. The student may learn from all this that our "BeechDrops" offers an inviting field for original investigation, and he will certainly agree with the remarks of the editor of the "Bulletin" that "the study of these plants, and a comparison of the various degrees to which the disuse has extended, would be an interesting contribution to science."

The poets seem to have overlooked this curious plant, but it was once quite famous in medicine. Dr. Titford, in his "Hortus Botanicus Americanus," says that it is called "Cancer-Root." "Every part of it," he continues, "is very astringent and bitter. It is considered a powerful remedy in dysentery, but it is chiefly celebrated as a cure for cancer, and formed the principal ingredient of Martin's Powder. Externally applied to obstinate ulcers, it has been very successful." The other ingredient of "Martin's Powder," we are told by Dr. Lindley in his "Vegetable Kingdom," was white oxide of arsenic. It is needless to say that this "remedy" has now fallen entirely into disuse.

The seed-bearing flowers, or rather buds, of Epiphegrus Virsiniana, appear soon after midsummer, and the barren, corolliferous ones about September. Later in the season large numbers of the former are produced wholly under ground.

The geographical range of the plant, as given by Dr. Gray in the "Synoptical Flora of North America," is from New Brunswick to Florida and Missouri. Our species is the only one known so far, but Mr. Austen has noticed a form which, he thinks, is probably a variety. 

VUL. II

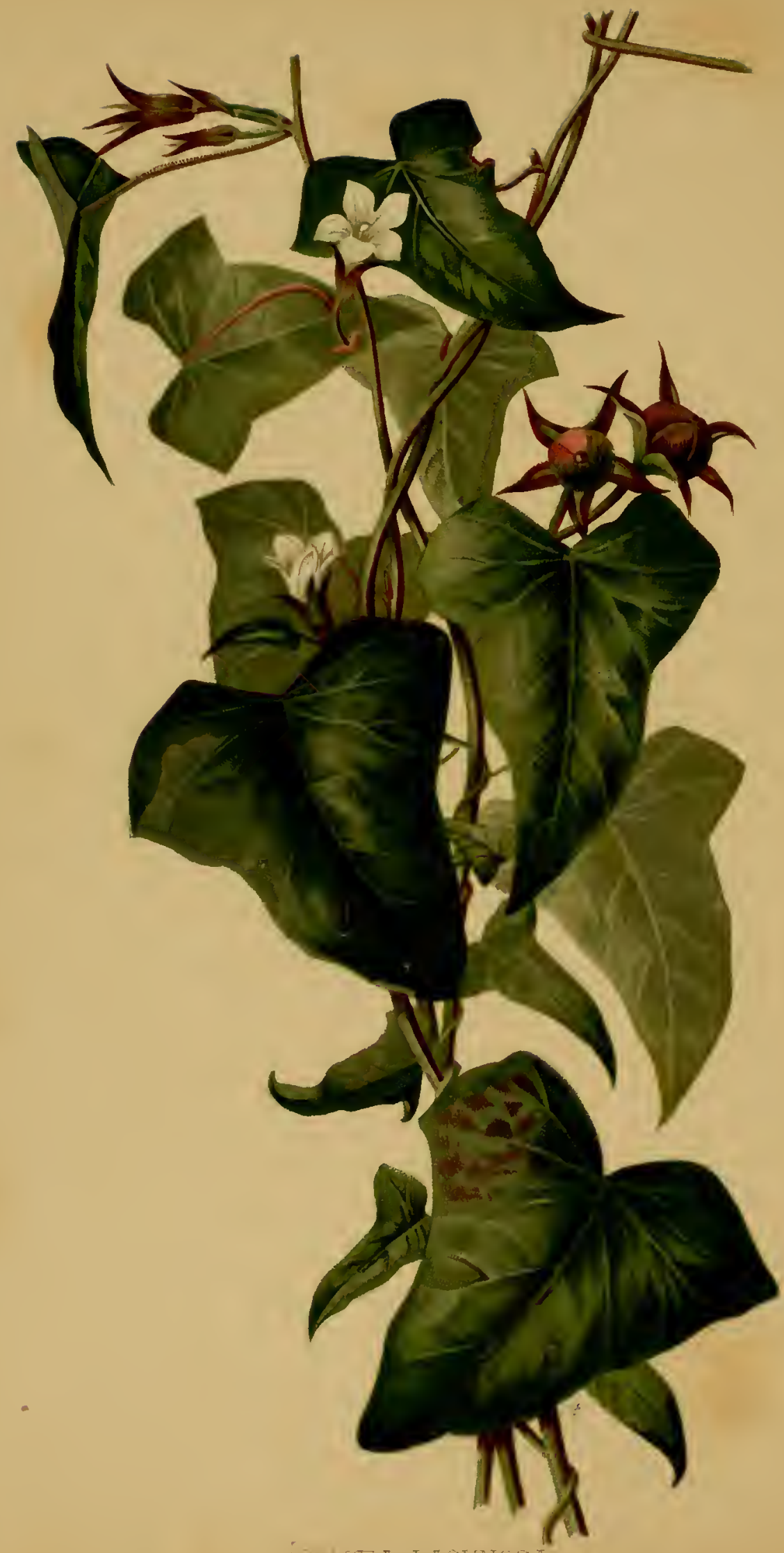




\title{
IPOMCEA I.ACUNOSA.
}

\author{
IVHITE STAR IPOMEA.
}

\author{
NATURAI, ORDER, CONVOI.VULACEAS.
}

\begin{abstract}
Ipomga LAcunos., Linnæus. - Minutely pubescent; stem twining; Jeaves cordate, acuminate, angular-lobed or entire, on long petioles; peduncle one to three-flowered, half as long as the petioles; sepals bristly ciliate, oblong-lanceolate, acute, half as long as the corolla; capsule pilous. Leaves two inches by one and one half inches, deeply cordate, often clecply three-lobed, petioles one to three inches long. Flowers about one inch long, white with a purplish rim. (Wood's Class-Book of Bohny. Sce also Chapman's Flora of the Southern L'nitud States, and Gray's Mamual of the Botany of the Torthern United Statis.)
\end{abstract}

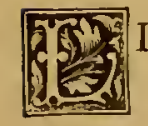

INNÆUS, in his "Genera Plantarum," says of the plants which belong to the genus Ipomace, that they are a kind of Convolvulus or Bindweed, and it was the resemblance to the latter genus which suggested the name to him. In Dr. Gray's "Manual" we read: "Name, according to Linnæus, from ips, ipos, a Bindweed (which it is not), and homoios, like." The resemblance is, indeed, quite striking, but a close examination will readily show that the genus Ipomoce is distinct from the genus Convolvulus, although the two are closely related, and both of them are members of the same natural order. By some of the earlier writers our species was actually regarded as a Convolvulus. Dillenius, for instance, who wrote in 1732, mentions it under that name, and Aiton refers to it as Convoluulus stcllatus, or "Star-Flower," while according to Gray and Chapman, C. micranthus, or the Small-flowered Bindweed of Riddell, is a name which belongs also to our plant. These synonyms appear to be the only ones of any consequence that may be applied to the species, and this is rather remarkable when we remember how 
long it has been known. It must have been one of the first of our native flowers that were introduced into English gardens, as it occurs in some catalogues of the year 1640 , and is mentioned by Ray, a botanical writer of the end of the seventeenth century.

The distinction between Ipomea and Convolvulus is to be found principally in the stigmas; for while the former has one capitate stigma, usually two-lobed, the latter has two stigmas, which are linear. Our species, Ipomea lacunosa, is easily known from all the other small-flowered American species by its shorttubed corolla, and by the pedicels of its flowers, which are much shorter than the leaves.

The whole family of Convolvulacea is noted for its flowers, which usually expand their corollas during the morning, or only in fair weather. The first of these facts is, indeed, so well known, that many of the species are popularly called "Morning Glories"; and the second, the closing of the flowers at the approach of rain, was looked upon, in the early days of modern teleology, as a clelicate contrivance for the protection of the stamens, and consequently of the pollen. Some modern physiologists, however, believe that plants with fully developed flowers, such as those of the Convolvulacce, have an abhorrence of perpetual close-breeding or self-fertilization, and if this be true, it might almost scem as if such flowers, not caring for their own pollen, would hardly take any special trouble to preserve it, and would rather prefer to keep their corollas open at all times, so as to lose no possible chance of receiving pollen from other flowers. Our Ipomoa lacunosa, indeed, appears to act on this idea, for, according to the writer's own observation, its flowers do not open in the morning only, nor do they close at the approach of rain. The specics is not common in Pennsylvania, and a specimen in flower there is certain to attract the attention of a botanist. 'The writer of this had to pass regularly once a week, about noon, by a hedge where a number of the plants were growing; but he never noticed any open flowers, until one day, very late in the fall, he happened to pass by the spot in a rain-storm. Our 
drawing was made from a mid-day specimen gathered on this occasion. The curious behavior of our plant in this respect, in which it differs so decidedly from its near relatives, is well worthy the attention of the student.

Another singular fact connected with the fertilization of the Ipomoca lacunosa is the disarticulation of its pistils. In most flowers these organs show a considerable degree of persistence after fertilization, or at least dry up only gradually. But in this species they separate by a joint near the base on the slightest touch, soon after the stigma has received its pollen. The flower, as a whole, is also of peculiar interest to those who are engaged in investigations concerning the causes which regulate the struc. ture and the behavior of plants. In many of the species of Ipomac the flowers are at least as large as the leaves. In I. lacunosa the leaves are as large as the average in its allies, but yet the flowers are proportionately very small. The seed-vessels, on the contrary, are as large as in almost any of the species, and indeed we may say that they are rather above the average as compared with the leaves. The reader will remember that flowers are really metamorphosed leaves. In the case of the corolla of the Ipomoa lacunosa we may therefore say that the five primordial leaves which were used in its production have been almost wholly arrested in their clevelopment, and yet, so far as we can see, the whole economy of the plant is just as good as if it had a corolla as brilliant and as gay as that of any "Morning Glory."

Although the innocent little white flowers of our species are not without their own attraction, the "vine" itself, to our mind, presents the chief beauty. The Ipomoca lacunosa is in this respect one of the most beautiful of all the American members of the genus. The angular and yet curving outlines of the leaves accord well with the twining habit of the plant, and give a rich elegance to its slender growth. Those who are inclined to give a poetical interpretation to the actions of nature, might see in the rich foliage a good reason why the flower is not as 
showy as in the other species. Nature was too intent on the leaves to give much thought to the flower.

The specific designation, lacunosa, is supposed to refer to a peculiar roughness of the leaves, as the word signifies that which is full of holes, pits, or "little lakes." But in all the living specimens which we have been able to examine, this feature was not very apparent. These specimens, however, were from Pennsylvania, which is the most northern point in the geographical range of our plant, and it may be that the peculiar character of the leaves is more prominently developed in the South, where the species is likely to flourish more vigorously. The flowers also seen a little less in size than they appear by the figures of other botanists.

Nuttall found the Ipomoca lacunosa growing very abundantly cn the banks of the Arkansas, and according to Prof. Wood it extends as far south as Louisiana and Florida. It probably occurs also in Texas, and is at home in Nebraska, Kansas, Illinois, and Ohio. On the alluvial soil along the Ohio River, according to an article by Mr. Butler in the "Botanical Gazette," the herbaceous vegetation is so rank that it is very difficult to force a way through it, and one of the chief components of this tangled and luxuriant mass is our species, which twines over everything. Dr. Chapman states that it is also found in low grounds in the middle districts of Georgia, and we have already mentioned that its northern limit is Pennsylvania. Curiously enough, it seems to be wanting entirely in the neighboring state of New Jersey. On the Pacific slope neither our own nor any other species of the genus Ipomoea appears to be represented, although several closely allied genera are native in California.

Our plant is in flower from August to October.

As the Ipomoea lacunosa has heretofore been without any common name, we have ventured to call it the "White Star Ipomœa," in allusion to the pretty little stars formed by its flowers. 
VOL. II.

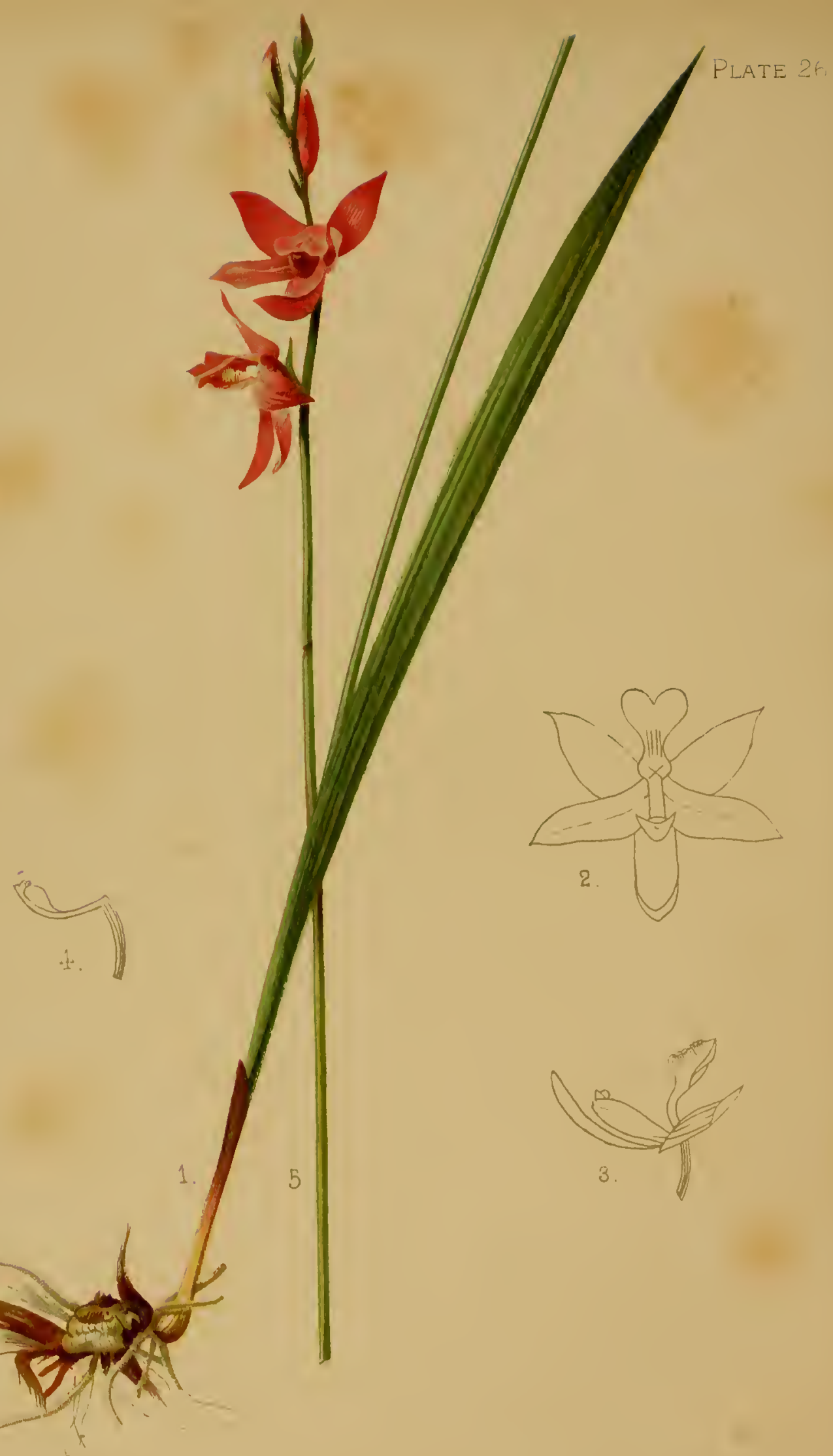

CALOPOGON PULCHELLUS. 


\title{
CALOPOGON PULCHELLUS.
}

\author{
GRASS-PINK. \\ NATURAL ORDER, ORCHIDACEE.
}

Calopogon rulchellus, R. Brown. - Scape two to eight-flowered; leaf linear-lanceolate, erect, keeled, many-nerved; flowers large, mostly approximate, bright purple; lateral sepals obliquely ovate, abruptly pointed, shorter than the lanceolate obtuse petals; lip broadly obcordate, acutely two-cared at the base; filanents of the crest decurrent on the claw, the lower ones purple and united ; ovary straight, two to three times as long as the lanceolate-subulate bracts; scape one and one half to two feet high; leaves six to twelve inches long; flowers one to one and one half inches wide. (Chapman's Flora of the Southern United Stutis. See also Gray's Munual of the Botany of the Northern United States, and Wrood's Clitss-Book of Botany')

HE great progress made in the knowledge of the structure and the relations of orchids since the time of Linneus has necessitated many changes of nomenclature, and hence, in looking into the history of the genera or species belonging to this order, it is sometimes rather difficult to trace them through the various names which some of them have received, and which in time have come to be looked upon as synonyms. Our present species, which seems to have been first introduced to the notice of botanists by Clayton (who, as the reader knows, collected in America in the last century), was named Limodonum tubcrosum by Gronovius, and Linnæeus adopted Iimodorum as the generic name in his work entitled "Species Plantarum." Some authors speak of our flower as "Ophrys barbata of IVilldenow"; but in the copy of Willdenow's "Species Plantarum" at our command, it is called Cymbidium pulchcllum. The discrepancy is probably due to an error copied and recopied by one author from the other, and instead of IVilldenow we should read WValter. Limodorum pulchellum is also met with, and 
Salisbury and Linnæus are both quoted as authorities for this name. The modern appellation, Calopogon, is first found in Aiton's "Hortus Kewensis," second edition, where it is said to have been adopted from a manuscript furnished by Robert Brown in $\mathrm{r}_{32}$. This name has since been generally received; and as no disposition has anywhere been shown to change it, we may conclude that botanists are convinced they have really arrived at a correct understanding of the structure and the essential characters of the curious flowers known as Orchids, a subject which, long after the time of Linnæus, was still enveloped in much mystery. The genus Limodorm, which once had many representatives, at present consists of barely a dozen species, the rest having been transferred to other genera.

Calopogon pulchcllus derives its generic name from the Greek kalos, beautiful, and pogon, beard, in allusion to the beautifully bearded lip; the specific name simply emphasizes its beauty, pulchellus being the diminutive of the Latin adjective pulcher, beautiful. The common name of the plant in Michigan, according to Mr. Coleman, is Grass-Pink.

The structure of an Orchid flower, seemingly so different from that of other flowers, is found to be very simple by the informed student. Still, almost every genus, or even almost cvery single species of the order, will illustrate some law of growth or form better than another, and it will therefore repay us to devote a few moments to the study of the flowers of our Grass-Pink. In them we are brought face to face with a very remarkable manifestation of the law of torsion, as shown in the final arrangement of the petals. The student knows that the type of most Orchids is ternary, or, in other words, that three leaves form a verticil in them whenever the spiral growth is rapidly arrested, and the spiral coil is brought down to a plane. We generally look for three leaves on the flower-stem of an Orchid of this kind; but in our present species only the central one of the three has been developed, while the lower has advanced no further than a reddish-brown sheath, and the third, or upper one, has been so en- 
tirely absorbed by the stem that only a small reddish-brown spot is left to show where the leaf might have been. In the flower, however, the ternary character is better developed. By the ground-plan given on the plate (Fig. 2), it will be seen that the lowermost division (lowermost, as it appears on our plan), and the two upper ones, standing at obtuse angles with it, form the lower series or verticil, or, as it would be called in other orders, the calyx. The lower leaf (lower, as before noted), if the three were drawn out on a stem as real, green leaves, would be the upper or third in the cycle, and we see that it has begun to change its form. The next drawing-in of the spiral twist, which has resulted in another cycle or verticil of three leaves brought down to one plane, has ended by bringing the upper normal leaf, and the most changeable as we have already seen, just opposite to where the twisting of the lower verticil ended. Now, in other Orchids, such as Blitic Tankervilla, for instance, which the writer has carefully observed, another tivist takes place in the ovarium, just as the petals are about to open, and after ail the twisting, so far described, has been done, and the result is that the lip (which in our flower is the uppermost leaf of the second verticil) assumes the position of the lowermost part of the flower. In Calopogon - and this is the remarkable feature of the genus - the extra twist has not occurred, and the result of this limited torsion is that the lip forms the upper instead of the lower part of the flower. We have arranged the plan (Fig. 2) expressly to show this interesting result.

The genus Calopogon is closely allied to Pogonia and to Are. thusa, and it is a noteworthy fact that our species is generally found growing in the neighborhood of Pogonia oplioglossoides. The two are evidently to a great degree companion plants, and it might be profitable to any one interested in evolutionary studies to investigate their ancestry.

It is almost impossible nowadays to speak of an Orchid without touching upon the subject of fertilization, and we cannot refrain from saying a few words in regard to this subject here. 
The Calopogon rarely fails to produce perfect seed-vessels. Yet it is very seldom that plants which depend on insects for their supply of pollen, as these are supposed to do, and which are not fertilized by their own pollen, produce seed from every flower; and it may be well, therefore, to note whether the insects are more industrious in the case of this plant than they are in other cases.

Quite an interesting account of the introduction of our flower to English gardens is given by Curtis in the "Botanical Magazine " for I 790 , as follows: "For this rare plant I am indebted to the laudable exertions of a late gardener of mine, James Smith, who, in the spring of $17 S S$, examining attentively the bog carth which had been brought over with some plants of the Dioncea muscipula, found several small, tooth-like, knobby roots, which, being placed in pots of the same earth, and plunged in a tanpit having a gentle heat, produced plants the ensuing summer, two of which have flowered, and from the strongest of these our figure was taken."

The specimen from which our drawing was made grew in Massachusetts, and was furnished to us by Mr. Jackson Dawson. The flowers on it are not half the size of those from North Carolina, figured in the "Botanical Magazine."

The Grass-Pink is not only beautiful, as its botanical name implies, but it is also sweet, and may serve as a text to those who believe that beauty sometimes is more than "skin-deep." It flowers in June and July, and is found in cold, peaty bogs all the way across from Maine to Minnesota, southward through Nebraska to Arkansas, but avoiding Kansas, and thence in a southeasterly direction to Florida. It is very rare indeed in Central and Western New York, and in many other places within the limits named.

Explanation of the Plate. - $\mathrm{r}$. Root, showing old tuber of last year, which decays as soon as the new one of the present year is fully formed. - 2. Outline plan of a flower, enlarged. -3 . Side view of a flower. -4 . The incurved column, showing how it is winged at the apex. -5 . Scape, with flowers. 



$$
\psi
$$




\title{
ORONTIUM AQUATICUM.
}

\author{
GOLDEN CLUB.
}

NATURAL, ORDER, ARACEA.

\begin{abstract}
ORONTIUM AQUATICUM, Limneus. - Leaves lanceolate, six to nine inches by two to three inches, smooth, of a deep green, velvet-like surface above, paler beneath, on long, radical petioles. Scape thick and terete, about a foot in length, closely invested by a short sheath at base, and ending in a spadix of a rich yellow color, covered with small, perfect, yellow flowers of an offensive odor, - the upper ones often tetramerous. (Woor"s Class-Book of Botary. See also Gray's 1 Tamul of the Botany of the Northern Unted States, and Chapman's Florit of the Southern ('nitid States.)
\end{abstract}

HE "Golden Club" is one of the most striking of all our 20. wild plants, as it has certain very characteristic features which are essentially its own. Although it belongs to the great Amm family, few persons, when secing the plant for the first time, would suspect the relationship, for in most aroid plants the spathe which surrounds the spadix immediately attracts attention, while in this species the spathe is entirely wanting, and the spadix, therefore, is naked. But as soon as we have familiarized ourselves with this fact, the relationship is seen easily enough, as the spadix itself has a general resemblance to its counterpart in the common garden Calla, or Richardia Ethiopica, which we all know to be an araceous plant, and the absence of color in the upper portion of the scape, that is to say, of the stalk on which the spadix is mounted, shows that if the spathe had been developed it would probably also have been white, in which case, as a matter of course, the resemblance to the Calla Lily would have been still more striking.

Another difference between our plant and the Richardia is to be seen in the flowers, which, it is hardly necessary to observe, 
form the yellow mass of the spadix. In the Richardia, or Calla, the stamens and the pistils are found in different flowers on the same spadix, or, in botanical language, the flowers are monœcious, while in the Golden Club the stamens and pistils are both present in each flower, thus making the flowers perfect or hermaphrodite. This difference in the flowers was seized on by Dr. Lindley in his "Vegetable Kingdom," and was made the principal ground of the division of the Arum family into two separate orders, the Orontiacea, according to Dr. Lindley, containing all those aroids which have perfect or hermaphrodite flowers, while into the family of the true Aracee are placed the species with monœcious flowers. Characters drawn from the presence or absence of stamens in the fruit-bearing flowers of this class of plants are, however, found to be variable, and hence the generality of botanists have not adopted Dr. Lindley's division.

Our plant seems to have attracted the attention of collectors at an early period, for we read of it as having been known to Ray, a famous English botanist of the end of the seventeenth century. Ray seems to have received it from the Rev. Joln Bannister, who made a catalogue of the plants of Virginia, which he sent to the English botanist in 1680. Darlington tells us that Bannister drew with his own hand figures of the rarer species, and that "he fell a victim to his favorite pursuit, for in one of his botanical excursions, while clambering some rocks, he fell, and was killed." He described our species as a "floating Artm with a naked spadix." Clayton, who sent the plant to Gronovius some fifty years subsequent to the time of Bannister, took it to be a "Potamogcton with large, glaucous leaves, and yellow flowers on a long, dense, stalked spike." As an Orontizm it first appears in Schreber's edition of the "Genera Plantarum" of Linnæus, where its distinction from the true Arums is pointed out.

The meaning of the name Orontium has been a matter of much speculation. Dr. Barton, in his "Flora of North Amer- 
ica," says it is an old Greek word, orontion, the etymology of which is entirely lost in obscurity. The same name is said to have belonged to an herb known to the ancients, and used in baths or fomentations as a remedy for the jaundice; "and we are told by Dr. Smith," writes Dr. Barton, "that some have sus. pected it to be a corruption of Origanum; while Prof. Martyn thinks the word comes from ogao, to see, a notion founded on a gratuitous assumption of the plant being serviceable to the eyesight." Dr. Pfeiffer, the distinguished German botanist, in a work recently published by him, suggests that possibly Linnaeus had the river Orontes in mind when he named the genus. The Orontes of the ancients, now called Bahr-el-asi by the Turks, is a river in Syria, emptying into the Mediterranean, and which has its source near Baalbec, a place celebrated for its wonderful ruins. It is difficult, however, to imagine what connection this river could have had with Orontium in the mind of the great father of modern botany; especially as our species, from which he named the genus, is exclusively American, and as no closely allied plant seems to grow in the waters of this ancient stream. If we might be allowed to venture a guess of our own, we would say that the name is probably derived from the same root from which the Latin aurum, gold, is derived; for undoubtedly the beautiful, bright golden spadix must have struck Linnæus quite as forcibly as it did those among the people who first gave the plant its common name of Golden Club. But if guessing should be out of order, we shall have to say, with Dr. Gray and other American botanists, that the origin of the name is obscure.

The structure of the seeds in the Orontium aquaticum, as in most aroid plants, is a very interesting subject of study. These seeds have no albuminous matter on which the young plant can feed until it is able to draw its support from the ground. But the young plant must necessarily get its nourishment somewhere, and Nuttall, therefore, says that the "gemmula (i.c., the germ in the seed) is viviparous, or commencing to vegetate as soon as mature," or in other words, that it commences to grow before it 
has left the parent plant, and while it is still within its carpellary coverings.

Our species is the only representative of the genus found in America, and the only other one known grows in Japan; but it seems to be inclined to vary. Pursh found a form with the leaves almost linear in the salt marshes near New York. Generally speaking, the plant occurs only on the Atlantic coast of the United States, and in marshes accessible to tide water. But the specimen from which our drawing was made grew wild near Philadelphia, in a swampy meadow on the grounds of the writer, situated some three hundred feet above the level of the Delaware River, and therefore inaccessible to the tides. Kalm, in his "Travels in America," says that the Indians call the plant "Taw-kee," and that they eat the dried seeds like peas, boiling them repeatedly to make them fit for food, or that they boil them in milk or butter, and use them instead of bread. Barton remarks that the Indians also use the roots after they have been roasted, as, in common with those of most aroid plants, they are poisonous when raw. If Barton's information is correct, the Indians must have much more of the spirit of industry than they usually get credit for, as these roots are generally deep down in the mud, and it requires great labor to get at them.

The peculiar, dark, glaucous green of the leaves of the Golden Club is very striking. When the plant grows under water, the leaves float on the surface, like those of the Potamogeton, but in swampy ground they erect themselves somewhat until they fall by their own weight. It is also interesting to note that the upper portion of the scape, which is white in the flowering season, turns as green as the other parts of the plant before fall; and Dr. Peyre Porcher is undoubtedly correct when he says that there is very much in the Orontium aquaticum "worthy of microscopic examination."

Explanation of the Plate. - I. Upper portion of a leaf, from a swampy meadow, taken in May. -2. Spadix, with portion of the scape, taken at the same season. - 3. Nearly mature seed-vessels, taken in September. 



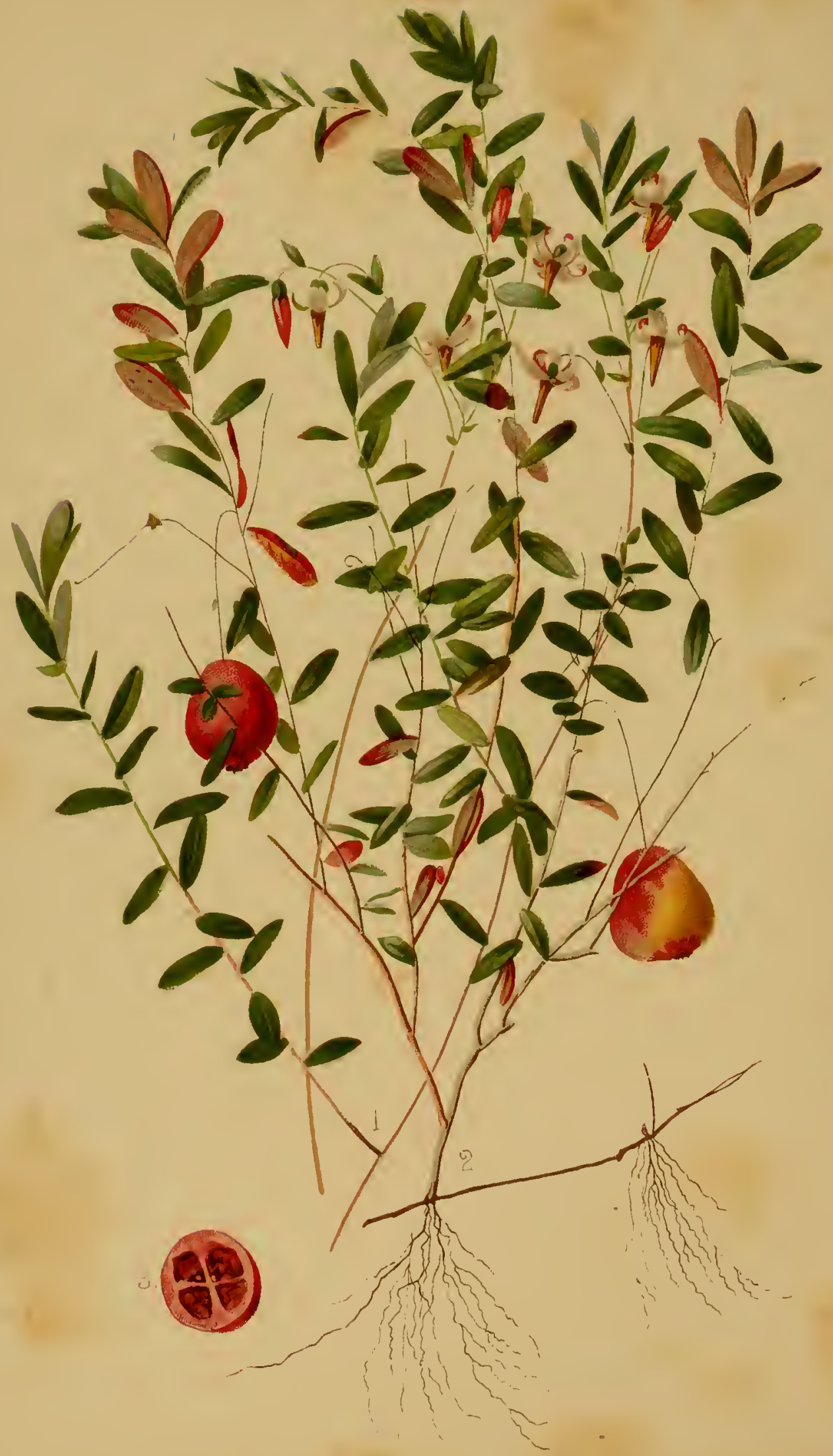




\title{
VACCINIUM MACROCARPON.
}

\author{
A MERICAN CRANBERRY.
}

NATURAL, ORDER, ERICACENE.

VAccinium macrocarpon, Aiton. - Stems elmigated (one foot to three fect long), the flowering branches ascencling; leaves oblong, obtusc, glaucous underneath, less revolute (than thuse of $I$. Oxycoccus), four to six lines long; pedicels several, becoming lateral; filaments scarcely one third the length of the anthers. (Gray's Mamul of the Botuny of the Norlhern Unitut States. Sec also Chapman's Flora of the Southern Unitud Shutis, and (under Oxy. coccus) Wood's Class-Book of Botuny.)

VERYBODY knows the Cranberry as a fruit exposed for sale in provision stores, but probably very few people are aware how pretty and interesting a little thing it is as a wild flower. In cultivation the plant changes somewhat, and for this reason we have especially avoided selecting for our illustration a plant from the rich, cultivated cranberry grounds, but have taken one from a boggy meadow in Germantown, Philadelphia, where it grows in company with coarse moss and sedges, and forms a fair part of wild nature. The flowering branches (Fig. I) were gathered early in June, and the fruiting branch (Fig. 2) in February, after the first thaw had taken away the snow beneath which the berries had been safely preserved during the winter. The fruit, as usually found on sale, is richer in color than we have it here, and the temptation to represent it of a dark, deep red would have been strong had we been guided by artistic motives alone. But our plan is to follow wild nature as closely as we can, and we have therefore represented the fruit just as it appeared on our specimen.

To those who only think of the Cranberry in the shape of sauce, and as an accompaniment to roast turkey, our plant will 
hardly seem capable of stimulating anything else besides the appetite. These matter-of-fact people, however, are mistaken; for not only is there a good deal in the history of the Cranberry worthy of attracting our attention, but it has also served as a theme for the poet. Louisa Twamley, in describing a bleak Alpine spot, thus sings of our plant:-

"The Cranberry blossom dwelleth there,

Amid these mountains cold,

Seeming like a fairy gift,

Left on the dreary world.

'T is such a wee, fair, dainty thing,

You'd think a green-house warm

Would be its proper dwelling-place,

Kept close from wind and storm.

But on the moors it dwelleth free,

Like a fearless mountain child,

With a rosy clieek, a lightsome look,

And a spirit strong and wild."

The capacity for endurance shown by the Cranberry is well expressed in these lines. It grows in wet, swampy places and in high northern regions, at great altitudes and on low levels, and often creeps over dry sands, in the blaze of scorching suns, where but very few other things would grow at all.

The very name of the Cranberry is suggestive, if, as some say, it was given to the plant because it is the favorite food of the crane on its return to the shores of Holland in spring. According to other authorities, however, the name is derived from the appearance of the flower, which, with its slender stalk, and the sharply pointed tube formed by the anthers around the pistil, has some resemblance to the head and neck of a crane. But whatever may have been the origin of the name, Dr. Prior thinks that it is one "of late introduction, for Lyte (a very old English writer) calls them (i. $\varepsilon$., our plant and its fruit) Marrish Whorts (Marshworts) and Finberries, and says (B. VI, c. I I) that 'there 
is none other name for them known." "There appears to be no doubt that the name was introduced from Holland.

The family name Vaccinium is frequently used by Virgil, the old Latin poet, but what particular plant he had reference to does not seem clear. Dryden, indeed, in his translation of the writings of Virgil, appears to have had the idea that the poet had a flower in mind rather than a fruit. The early botanists, however, applied the name to the Cowberry, Vaccinium Vitis Idca, but in so doing they apparently confounded Vaccinium, the fruit of the whortle, and vaccinum, that which belongs to a cow.

There is some little controversy among botanists as to the genus to which our species belongs. Many protest that it is not a Vaccinium at all, and therefore call it Oxycoccus (Greck for sharp berry, from the sharp or acid taste of its fruit), which is the name given to the true Cranberries by Persoon, a distinguished botanist of the beginning of the century. Dr. Darlington, in his "Flora Cestrica," remarks: "I have followed Dr. Gray, and others, in reducing this to a section of Vaccinizm, though I think there are many admitted genera based on more slender foundations." The chief points relied on for distinguishing Oxycoccus from Vaccinium are found in the corolla and the fruit. In Vaccinium the corolla is split into four long, narrow, and recurved segments, and its fruit is in four divisions (Fig. 3), without the false partitions which make the fruit of other allied plants appear as if they had more cells.

Of the "true" Cranberries there are several species; and of these the American Cranberry, to which this chapter is devoted, Vaccinium macrocarpon, or Oxycoccus marcrocarpus, according to the author whom we may follow, has much the largest fruit. It is this fact to which it owes its specific name, macrocarpon being Greek for "large-fruited." Mr. Thomas C. Archer, a wellknown English author on economic botany, says that "the American Cranberries somewhat resemble red currants, but are more than twice as large, and have no remains of the calyx at the top of the berry," and no one will accuse Mr. Archer of having exaggerated the size. 
The European Cranberry, Oxycoccus palustris, is also found in our country, but it is confined to the mountains and the extreme northern states. Our species is said to occur in Japan, but Dr. Gray doubts the identity of the Japanese form with our own. In regard to the differences between the Great American Cranberry and the Oxycoccus palustris, Mr. Loudon remarks that the two can be distinguished from onc another by the bracteas, which in the Great American Cranberry are situated on the upper part of the pedicel, while in $O$. palustris they are on the lower part; and Don notes that the berries in our species, although larger, are not so high-flavored as those of the O. palustris, which come to England from Russia. Dr. Peyre Porcher says that the red-fruited variety yields a juice which has been employed to stain paper or linen purple.

The hardy perseverance under difficulties, which the poetess sings of, might be further illustrated by the manner in which our plant grows under culture. As we have before noted, its natural place of growth is among grass and other coarse herbage, against which latter, however, it generally manages to hold its own. When the cultivator wishes to improve such a native Cranberry bed, he covers the soil several inches deep with sand, and the coarser weeds, excluded from the light, give up at once and die; but the Cranberry pushes through to the surface, sending out its hair-like roots as it grows, till at length it finds itself in almost undisputed possession of the ground, when it rewards the assistance given it by an abundance of large fruit. The plant is, therefore, a good illustration of the axiom that the race is not always to the swift, nor the victory to the strong.

Our Great American Cramberry is chiefly at home in the northeastern section of the United States. Its most southern point, according to Dr. Chapman, is North Carolina, and thence its boundary seems to take a northwestern direction.

Explanation of the Plate. - I. A wild plant, gathered in Pennsylvania in June. $-2 . \Lambda$ branch with fruit, from the same spot, gathered iu February. -3. Cross section of the four-celled fruit. 



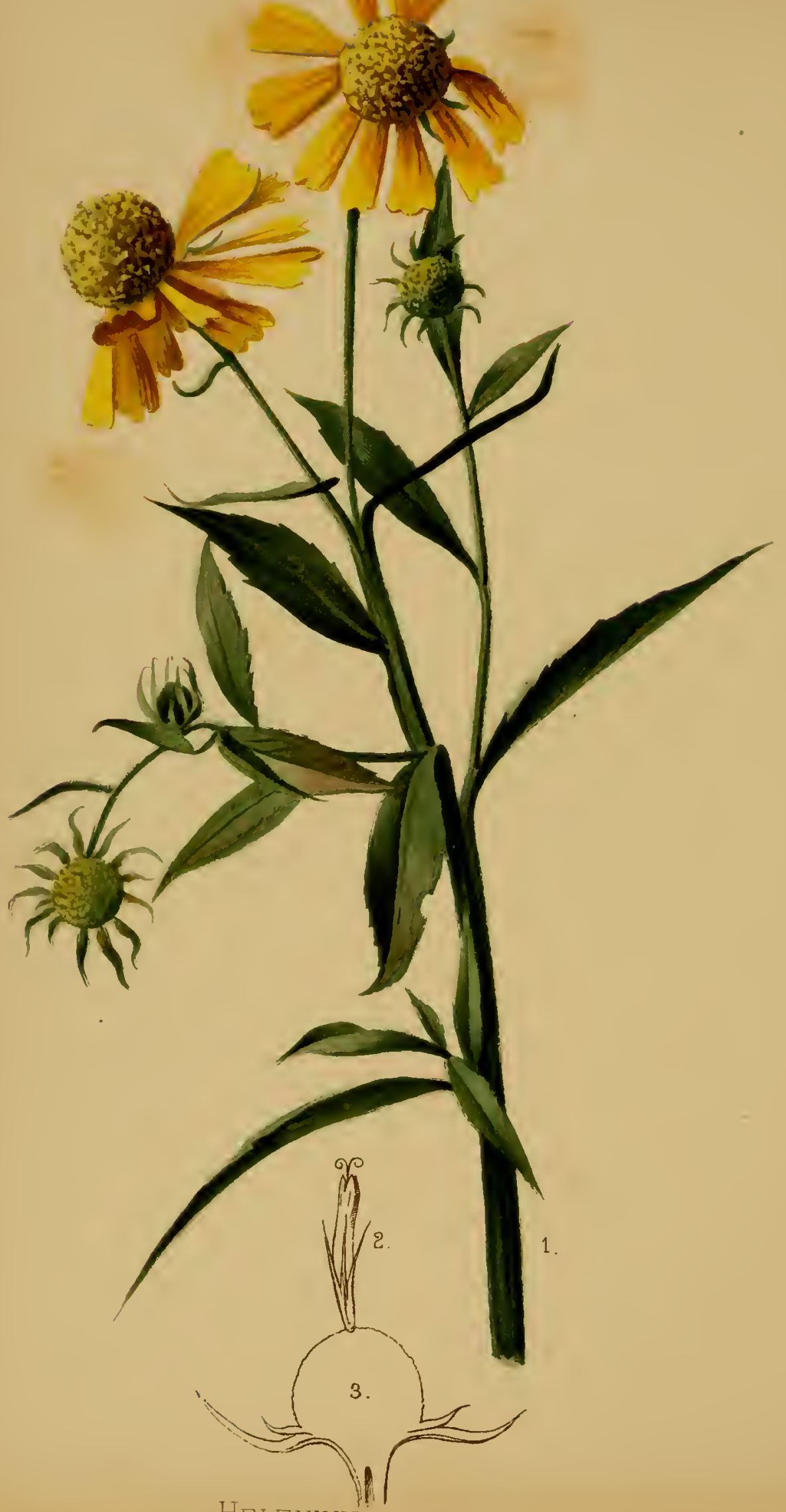




\title{
HELENIUM AUTUMNALE.
}

\section{AUTUMN SNEEZEIVORT.}

\author{
NATURAL ORDER, COMPOSITE. (ISTERACEE OF LINDLEY.)
}

\begin{abstract}
HeleniUM AUTUMNALE, Limxus. - Leaves lanceolate, serrate, smooth or slightly pulescent, decurrent flowers loosely corymbous. Stem two to three feet high, branching strongly, winged by the decurrent leaves. Leaves tapering to each end, or elliptic-lanceolate, more or iess deeply serrate. Flowers large, numcrous, terminal, with drooping rays, each ending in three obtuse teeth, and longer than the large, glohous clisk. (Wood's Cliss-Book of Botuny. Siee also Gray's Manuel of the Botany of the Norihern United Stutes, and Chapman's Flori of the Southern United Sultes.)
\end{abstract}

HERE comes from youder height

A soft, repining sound,

Where forest leaves are bright, And fali, like flakes of light,

To the ground.

It is the autumn breeze

That, lightly floating on,

Just slims the weedy leas,

Just stirs the glowing trees,

And is gone.

He moans by sedgy brook,

And risits, with a sigh,

The last pale flowers that look,

From out their sunny nook,

At the sky.

There are times when those who are acquainted with Nature in her autumnal moods will recognize at once the eminent truthfulness of the beautiful picture drawn by the sweet poet whose death we have only lately lamented. When speaking of the "last . pale flowers," Bryant, of course, had no particular flower in view, and the reader may therefore fill in the details of the picture 
from his own experience or from his own fancy. For our part - and, no doubt, we can speak for many of our readers, as they are all diligent collectors of wild flowers - the Hclcnium autum nale is one of the first of the plants that come to our mind as we imagine the scene described by the poet; for not only does it grow "by the sedgy brook," but it is likewise one of the commonest of our autumn flowers, and one of the last of those

\section{"that look, \\ From out their sunny nook, \\ At the sky."}

The lateness of the season into which the "Autumn Sneezewort" continues to flower, does not, indeed, seem to be recognized by the generality of botanists. Prof. Wood says that it blooms in August, Dr. Chapman extends the time from August to September, and Dr. Gray gives September only. Rafinesque, however, tells us that "it is a fine plant, rather ornamental, and adorning in the fall the meadows with its golden blossoms, appearing from September to November"; and this accords exactly with the experience of the writer of this. In Europe, also, the plants belonging to the genus Helenizm seem to have been known long ago for their late-flowering habits. It used to be the custom to dedicate to the saints some flower that opened about the days consecrated to them; and from a monkish almanac of the last century we learn that this species of Hclcnium was consecrated to Edward the Confessor, whose festival was celebrated on the thirteenth of October.

The growth "by sedgy brook" is especially applicable to our Autumn Sneezewort, for the testimony on record regarding its places of growth is almost unanimous in locating the plant on alluvial soil, or along the banks and borders of streams. The writer of this has seen it, especially on the banks of the Schuylkill River, so low down near the water's edge that the October rains which filled the river entirely submerged the plants, leaving both leaves and flowers covered with the river mud as the waters subsided. 
Perhaps this fondness of our species for the water-courses is one of the reasons for its wide distribution, as the plant is thus cnabled to scatter its seeds on the stream, which is compelled to transport them. There are few plants so widely distributed over the United States as this. It does not, indeed, occur in the Portland Catalogue of Maine plants, and it is rare in the New England States, according to Dr. Gray; but as we reach the New York line we find it to be quite abundant, and it continues to be more or less so all through the Atlantic States down to the Gulf of Mexico. West of the Mississippi it was collected in Texas by Lindheimer, in Arkansas by Lesquereux, in Kansas by Snow, in Nebraska by Aughey, in Iowa by Arthur, and in Minnesota by Parry. The writer of this also found it in Colorado, and the botanists of California report it as growing along the greater part of the Pacific slope. This very wide and flourishing distribution is one of the most remarkable features in the history of the species.

Being so easily found, our plant was of course among the earliest discoveries in American botany. Jacob Cornuti, the oldest writer on the plants of this continent, who published a history of the plants of Canada about 1635, refers to the Hiclnium autumnale as a sort of yellow Aster. Morrison, who also wrote a history of plants in I7I5, mentions it as a sort of Chrysanthomum; and it is reported by Aiton as having been in cultivation in the Chelsea Garden, near London, in 1729. Since it received its present name from Linnæus, its nomenclature has undergone but little change. It varies somewhat in the widely separated localities in which it is found, and this has given rise to a few synonyms, but these are not likely to confuse the student, and are, therefore, hardly worth while recording here.

Rafinesque says of our plant that it is a tonic, febrifuge, and errhine; the latter meaning a medicine which is to be used like snuff to induce sneezing. It is from this quality that the Helcnium autumnale derives its common name of Sneezewort, 
in company with all the other members of the genus. "It may be used," continues Rafinesque, "in diseases of the head, deafness, amaurosis, headache, hemicrania, rheumatism, or congestion in the head and gums, in which cases the shocks of sneezing are often useful when other medicines can hardly avail." It appears that the flowers are most efficient in producing that irritation of the nerves which causes sneezing. Cattle, it is said, will not touch the plant, the whole of which, according to Nuttall, is intensely bitter, with something of the aroma of camomile. The same botanist, indeed, observes that our species would probably answer all the medical purposes of the flower just named.

Botanically the globular head of the $H$. autumnale, which is composed of the disk-florets, will attract attention. The shape of the receptacle, which usually gives its form to the head, is often used as a generic as well as a specific character in the classification of composites. The toothed, awn-pointed scales of the pappus, as well as the slightly hairy achenia (Fig. 2), are also worth noting particularly, as they afford good distinctions for determining the species. The cylindrical corolla, somewhat closed at the mouth (Fig. 2), is characteristic of the genus, there being little difference in the species in this respect.

The name Sneezewort, which we have placed at the head of this article, is the one most commonly applied to our species, although it sometimes bears the name of Swamp Sunflower, and False Sunflower.

Explanation of the Plate. - I. Branchlet from a branching head. - 2. Disk-floret and achene, slightly enlarged. -3 . Globular receptacle showing the double row of involucral scales. 



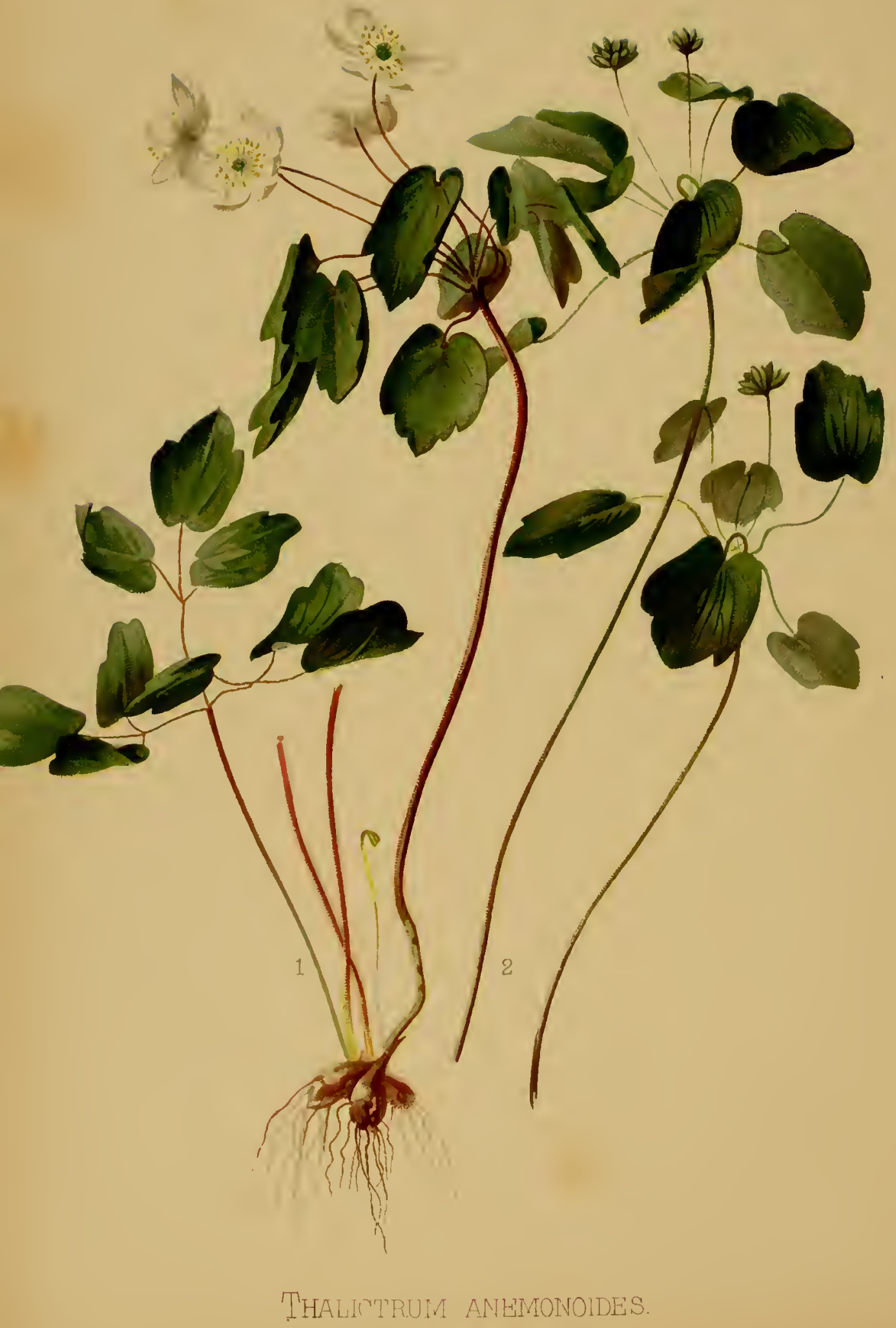




\title{
THALICTRUM ANEMONOIDES.
}

\author{
WIND-FLOWER MEADOIV-RUE.
}

NATURAL ORLER, RANUNCULACE.E.

\begin{abstract}
Thalictrum Anemonomes, Michaux. - Glabrous; stem and slender petiole of the radical leaf (a span high) rising from a cluster of thickened, tuberous roots; the latter (i.c., the radical leaf) two to three-ternately compound; leafiets roundish, somewhat three-lobed at the cnd, cordate at the base, long-petiolulate, those of the two to three-leaved, one to twoternate involucre similar ; flowers several in an umbel; sepals oval (one half inch long, rarely pinkish), not early deciluous. Rarely the sepals arc three-lobed, like the lcaflets. (Gray's Manual of the Fotany of thic Northerre C'nitud States. See also Chapman's Flora of the Southern United States, and (under Ancmone thalictroidis) Wood's Chass-Book of Botany.)
\end{abstract}

FE. N Shakespeare's amusing "Comedy of Errors" the interest centres on a pair of twin brothers, both named Antipholus, and just like one another, but each unaware of the other's existence. One of the twins resides at Ephesus, and the other at Syracuse; and the most comic mistakes naturally occur as they cross each other's path. The fun is still further augmented by another pair of twins, both named Dromio, both also exactly alike, each also unaware of the other's existence, and one a servant to the Syracusan Antipholus, while the other holds the same relation to him of Ephesus.

The Thalictrum ancmonoides, to which our present chapter is devoted, and the Anemone nemorosa or Wincl-Flower, might do as twin brothers in some floral "Comedy of Errors"; for it is not easy to tell, at a first glance, which of the two is the Ephesian and which the Syracusan, or, rather, which of them belongs to the genus Thalictrum and which to that of Ancmonc. Our Thalictrum ancmonoides flowers in spring at the same time 
with the Wind-Flower, and numbers of persons pass the places where the two are growing, unconscious of the fact that both are there; and, indeed, there is a singular mimicry of the Anemone in many of the characters of our Thalictrum. The whole habit of growth, the involucre-like leaves, the form and structure of the flower, - all these resemble one another so closely in the two flowers that it is reaclily understood how the superficial observer may be led into the mistake of believing the tiwo plants to be identical. It is only when we examine the maturing seed-vessels that we see the true relationship of our plant, which inclines towards Rantunculus rather than towards Anemone. But the superior importance of the fruit over the inflorescence, as a means of determining the relationship of flowers, has been recognized only at a comparatively late period. In most of the old herbariums, good flowering specimens were thought to be all-sufficient; but now the true botanist is quite as anxious to secure good specimens of the fruit as of the flower. It is not to be wondered at, therefore, that the botanists of the past were rather divided in regard to the classification of our species. The great Linneus believed it to be an Ancmone, and in this view he was followed by Aiton, IVilldenow, and most of the older European botanists, and by Pursh and Barton among the earlier botanists of America. Michaux first classed the plant with Thalictrum, under its present specific name, and the same classification has been adopted by Darlington, Torrey, Gray, Chapman, and the majority of modern botanists in America, and by De Candolle and others abroad. It is interesting to note, as showing how evenly divided scientific men have been on the question of the relationship of these "two Dromios," that of the thirty references to our species given by Mr. Sereno Watson in his "Bibliographical Index to North American Botany," fourteen are under the name of Ancmonc, and sixteen under that of Thalictrum.

The Thalictrum ancmonoides has heretofore been popularly known as the Rue Anemone, but as the majority of botanists 
have now agreed that it is not a true Anemone, it would be better to call the plant the Wind-Flower Meadow-Rue, and this name wc have, therefore, placed at the head of our chapter. It is more correct than the old name, and yet keeps up the connection with the

\section{"wind-flowers frail and fair,"}

with which the species will probably always remain associated in the popular mind.

Together with the rosy hues of the Spring Beauty, the skyblue of the Liverwort, and the delicate pink occasionally seen in the Wind-Flower, our Thalictrum often makes as pretty a picture of early wood scenery as we can well imagine; and one might almost think that Bryant had such a scene in view when he wrote: -

"Here doth the earth with flowers of every hue Heap her green breast when April suns are bright, Flowers of the morning-red or ocean-blue, Or like the mountain frost of silvery white."

The Wind-Flower Meadow-Rue is strictly an American plant, and is rather limited in its range. It is common in all the states along the Atlantic seaboard, but in the IVest does not occur beyond Nebraska, in which state it was found by Prof. Aughey. Further south, beyond the junction of the Missouri and the Mississippi, its only location west of the latter river seems to be Arkansas, where it was found by $M I$ r. George $A$. Butler.

For cultivation our species is remarkably well fitted, provided that it be not planted in a very dry and sun-exposed place. In a partially shaded situation, it continues to increase the number of its flower-stems from year to year, and makes a much showier appearance than in its wild state. The many shades of color in the flowers, from pure white to rose, give promise of good results under a florist's care, and double flowers, the 
tendency to make which is often met with, even in the wild condition, might also be looked for. It seems that this tendency has long been noticed and appreciated by cultivators. Thus Peter Collinson, in a letter to John Bartram, dated Jan. 31, 1738, and published in Darlington's "Memorials," speaks of having received a plant with double flowers from the latter; and Dr. Barton, in his "Flora of North America," which was published as long ago as IS2 I-23, says that "when duplication of the petals happens, the plants are highly valued for culture." We have heard of plants which were entirely doubleflowered being found in Michigan and elsewhere; and Prof. Thomas C. Porter, in the "Botanical Gazette" for December, I 875 , gives the following account of a similar specimen: "From the woods in the neighborhood of Lancaster, Penn., I obtained a stock of Thalictrum ancmonoides, Michaux, now growing in my garden, whose flowers have nearly all stamens converted into petals. They are very delicate and beautiful, and look like miniature white roses tinged with pink." There is little doubt but these double flowers could be found oftener if looked for more attentively, and the search for them might give much zest to the rambles of the young flower collector.

The Wind-Flower Meadow-Rue, although an exclusively American plant, seems to have been entirely neglected by our poets; and this is due, no doubt, to the fact that it has generally been confounded with the Anemone. Material uses, medicinal, economic, or otherwise, it also has none; and the only excuse for its existence must, therefore, be sought in its beauty.

Explanation of the Plate. - I. Full-sized flower-stem, with root attached, in early May. - 2. Stems, with half-mature seeds, in early June. 



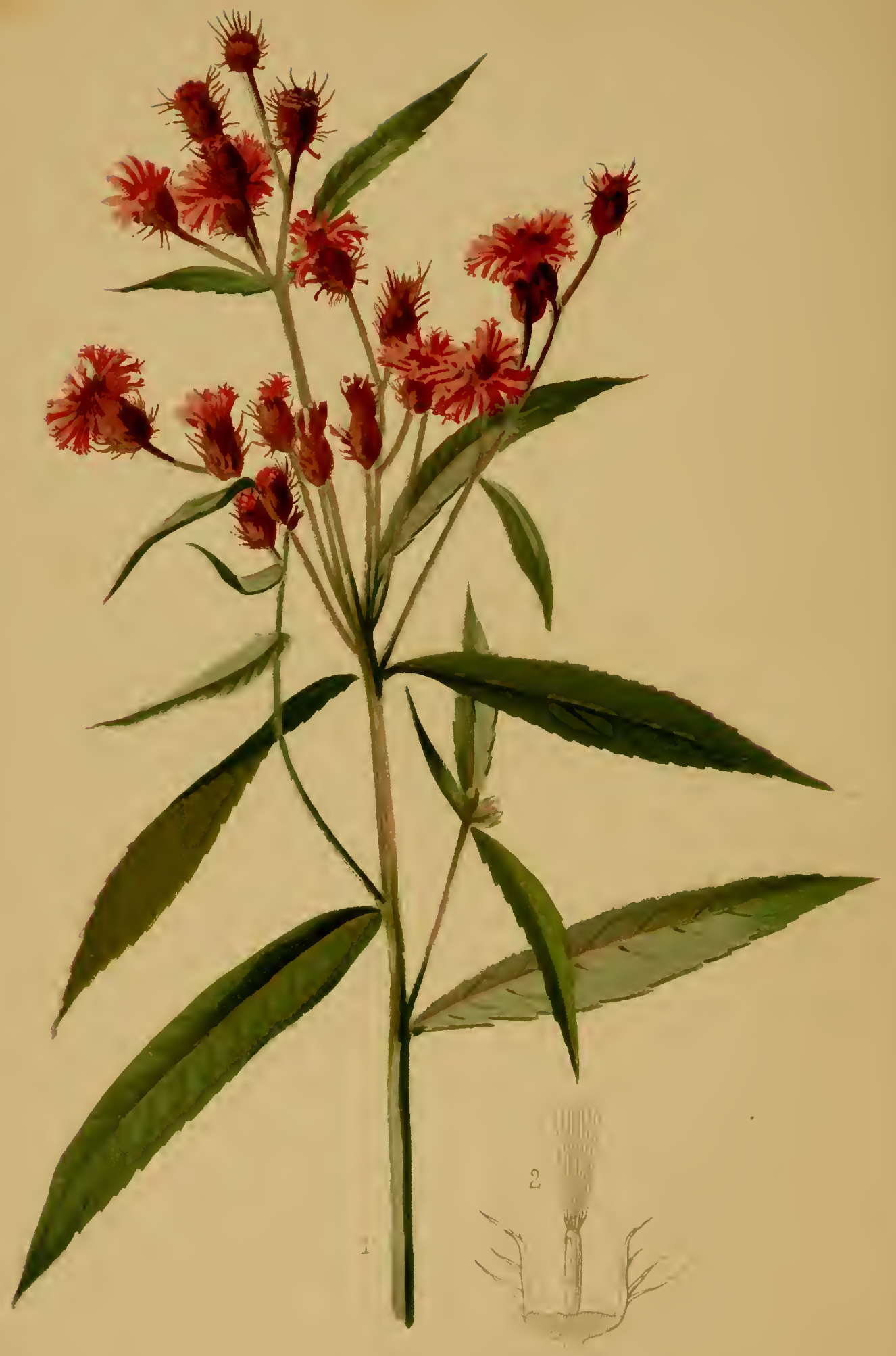

VERNONIA NOVEBORACENSIS. 


\title{
VERNONIA NOVEBORACENSIS.
}

\author{
IRON-IVEED; FLAT-TOP.
}

NATURAL ORDER, COMPOSITE. (ASTERACEE OF LINDLEI.)

\begin{abstract}
Vernonia Noveboracensis, Willdenow. - Leaves numerous, lanceolate, serrulate, rough ; cyme fastigiate; scales of involucre filiform at the ends. (Wood's Class-Book of Botany. Sec also Gray's Minual of the Botany of the Northern United States, and Chapman's Flora of the Southern Unitat States.)
\end{abstract}

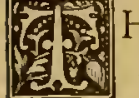

HIS pretty native flower is well known by sight to most people, for, growing two or three feet high, and in great abundance in low grounds in the districts allotted to it by $\mathrm{Na}$ ture, and being of so conspicuous a color, it is readily recognized, even by those who take no special interest in botany. To the farmer, indeed, it is only too well known, as it is apt to be troublesome when it finds itself in congenial soil; and authors on agricultural subjects are not, therefore, accustomed to speak of it in very eulogistic terms. Thus Dr. Darlington writes in his "Agricultural Botany": "The plant is quite common in moist, low grounds and along fence-rows. Its worthless character and coarse, hard stems cause it to be regarded as a rather obnoxious weed in our meadows; and of course it is carefully eradicated by all neat farmers." Dr. Michener, in his "Manual of WVeeds," also has a bad word for it. He says it is "a worthless and troublesome weed in moist bottom lands, unless carefully disposed of. Being a rank per-annual, the proper means is to destroy the root either by ploughing or grubbing." It is probably from the "coarse, hard stems," alluded to by Dr. Darlington, that the plant has obtained the common name of Iron Weed. 
Those who, as cultivators, have become acquainted with the habits and strength of the plant, cannot but admit the justice of the remarks just quoted; while at the same time they will be sorry that it is so, if they are not cultivators only, but lovers and admirers of beautiful flowers also. For, looked at simply as a wild flower, the Iron-Weed is sure to commend itself to our attention; and in foreign countries, where it has been introduced by gardeners, it is esteemed as a pretty, ornamental flower. Mr. Robinson, who includes it in his work on beautiful "Hardy Flowers" for English gardens, says it grows very large and vigorous there, often attaining a height of from five to eight feet, and is valuable "for naturalization amongst the tallest perennials in any soil." Truly, our plant might say that a prophet is not recognized in his own country, for, being so common with us, it is looked upon with disclain by our cultivators. Still there might be discovered varicties of color or of habit worthy of the gardener's attention, for the plant shows a clisposition to vary in almost all locations. It is not uncommon to find specimens with the flowers of a much clarker purple than those shown on our plate, and the writer was informed by Mrs. E. S. Cox, the wife of the distinguished state geologist of Indiana, that she hacl found a white variety. Mr. G. C. Brodhead, in the second volume of the "American Naturalist," also records the finding of a similar form.

The chief beauty of our plant is, however, derived from its pleasing color. It is not, indeed, without artistic interest in its general arrangement, but it must nevertheless be confessed that an analysis, according to the rules of beauty, does not develop very striking results; and the whole panicle, more especially, is so irregular as to defy all rule. Sometimes the pedicel or flower-stalk is long, and bears only a single flower; at other times another flower with a short stalk, or even stalkless, shares the branch. The leaves, although alternate on the main stem, are occasionally opposite on the upper portion, as shown on our plate. The branches of the fascicle often have a strong hori- 
zontal tendency, in which case a whole string of flowers is formed on the upper surface of each. It was this formation, probably, which suggested the name of Flat-Top. Iron-IVeed, however, is much more common, and will probably prevail in the end.

Botanically, our Vemonia Noveboracensis offers a good deal of interest. Although the plant has been long known to botanists, its name Vernonic is neverthcless of comparatively modern origin, having been given to the genus (in 1791) by Schreber, who was the editor of one of the editions of the works of Linneus. It commemorates the labors of William Vernon, an English botanist, who came to America in company with Krieg, a German, and made collections, chiefly in Maryland, towards the end of the seventeenth century. Vernon, however, is not specially connected with this genus, so far as we know, and the honor conferred on him by Schreber was simply intended as an acknowledgment of the greneral services he had rendered to botany in making his American collections.

Linneus regarded our plant as a species of Scrratula. Referring to this supposed relationship, Nuttall writes in $S_{27}$ : "Related to the thistle, through the medium of the very proximate genus Seratula, is that of I cmonia, peculiarly American. . . . Besicles the generic character derived from the calyx, which is that of Scratula, the stigma, as in Liatris, is bifid; but the most decicled trait of Vernonia is in the existence of a doublo pappus, the exterior short and chaffy in some degree, and the interior capillary." The genus remarkably illustrates the progress which has been made in our knowledge of plants. When Nuttall published his "Genera of North American Plants," he took occasion to say that there were then about twenty species of Trmonia known, and we have just seen that he looked upon the genus as "peculiarly American." But only ten years later, in $s_{3} 6$, when the genus was worked up for De Candolle's "Prodromus," no less than two hundred and ninety species were named and described, many of them being natives of all parts of 


\section{24 VERNONIA NOVEBORACENSIS. - IRON-WEED; FLAT-TOP.}

the world, outside of America, and many also brought in from other genera, with which they had previously been classed.

Several species have been described by botanists, which afterwards proved to be identical with $V$. Noveboraccnsis, or at least not sufficiently distinct from it to warrant their being reckoned as separate species. Prof. Wood and Dr. Chapman note that $V$. praalta of Lessing, and $V$. tomentosa of Elliott, are not distinct species, but at best only varieties of $V$. Novcboraccnsis.

The somewhat formidable specific designation of our plant, Novcboracensis, is Latin, and means "belonging to the state of New York." It used to be customary to name plants from the places from which they were received, and our plant was first sent to Linnæus from New York, probably by Dr. Colden, a valued correspondent of the great naturalist. But the species is by no means confined to New York, although it happens to be more abundant there than further north. Dr. Gray gives Maine as its most northerly limit, but it is probably rare in that state, as it is not included in the Portland "Catalogue of Maine Plants." Dr. Chapman says it grows "from Florida and Mississippi northward." Prof. Lesquereux names it as very abundant in Arkansas, but the writer of this never found it in either Arkansas or Texas, although a closely allied species, which might easily be mistaken for $V$. Noveboraccnsis, is abundant in both these states. It is remarkable that in the state of Michigan our species should only be found in the eastern part, while the very elosely allied species, $V$. fasciculata, takes its place in the western part, according to the observation of Mr. Frank $\mathrm{H}$. Tuthill, of Kalamazoo, as recorded in the "Botanical Gazette." It is again found in Iowa, and extends to Nebraska, where its march westward ceases.

Explanation of the Plate. - I. A rather small fascicle of tlowers. - 2. Achene and pappus. 



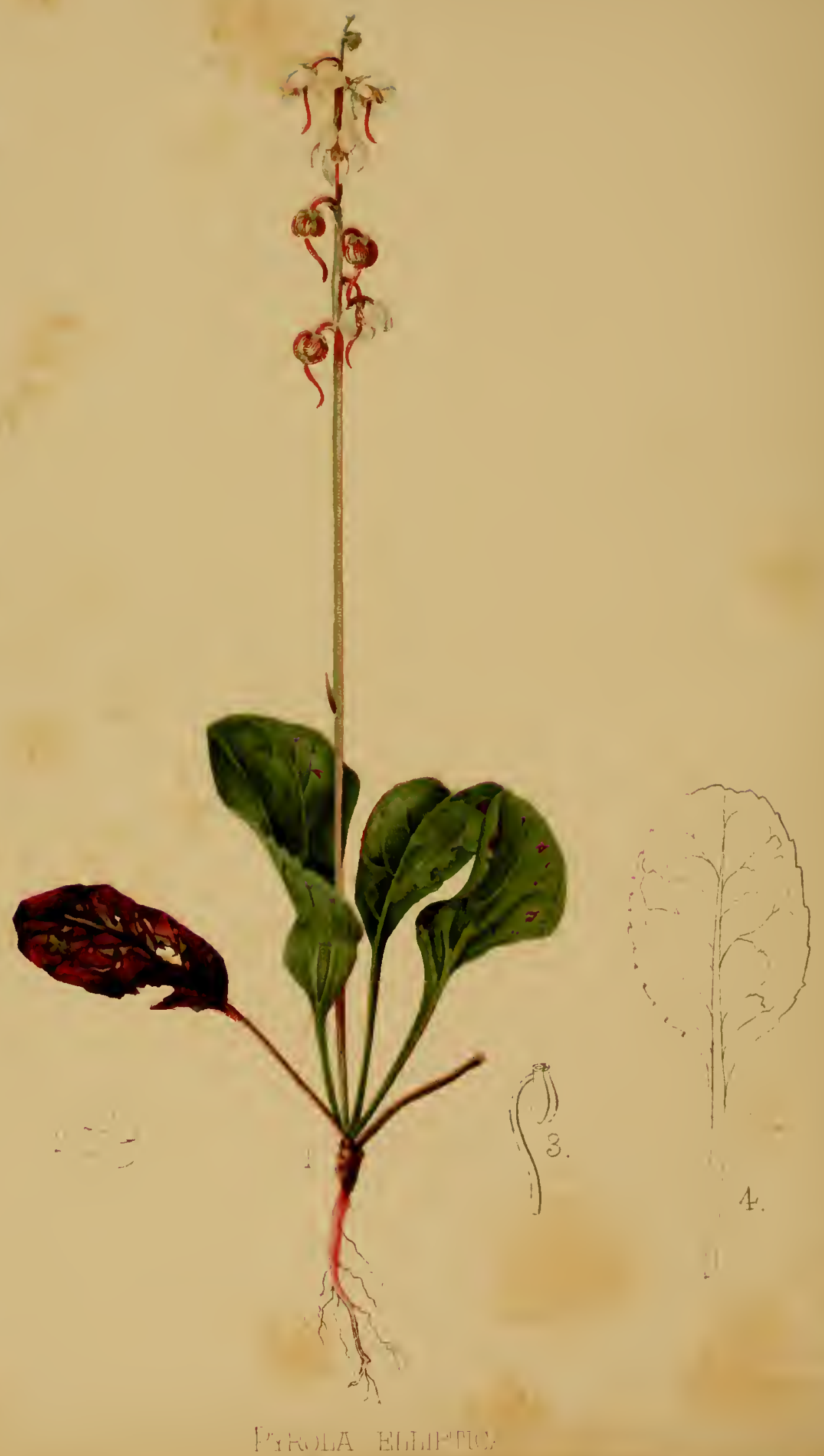




\title{
PYROLA ELLIPTICA.
}

\author{
IVINTERGREEN; SHIN-LEAF.
}

NATURAL OKDLR, KRICACL.E.

\begin{abstract}
l'rroli tiliptica, Nuttall. - Lcaves membranaceous, oblong-oval and obtuse, or cliptic-ovate, p)licately scrrulate and acute, lamina always much longer than the petiole; scape naked or furnished with a single scale; branches lincar and subulate; calyx five-toothed, points subulate, reflected. (Nuttall's Gincra of Aorth Amorican Fiznts. See also Gray's Monual of the Botuny of the Northern Unitud Stutes, Gray's Synoftical Flora of Sorth Americir, Wood's Class-Book of Botany, and Darlington's Flora Cistrica.)
\end{abstract}

HE species of Pyrola which we are about to introduce to 5. the reader secms to have been confounded with the more common Pyrola rotundifolia, until the distinction between the two was pointed out by Nuttall, in his "Gencra of North American Plants," published in ISIS. We have therefore adopted Nuttall's description, although, as a rule, we prefer to quote from those works which are most likely to be within reach of the reader.

Referring to the resemblances and differences between the two species in question, the author just named goes on to say: "It (i.c., Pyrola clliptica) is common around Philadelphia and in the woods of New Jersey with $P$. rotundifolia, nowering in June. It is nearly allied to $P$. rotundifoli.z, but distinct both in character and aspect; the whole plant is smaller, the scapes are low and slender, accompanied by smaller flowers, which are white and odorous, the petals are oblong oval, about equal in length with the stamina, which become fulvous, segments of the calyx semi-ovate and dilated; scapes acutely triquetrous, rarely convolute; style very long, stigma annulatc, five-lobed." Dir. W. P. C. Barton, who published a "Flora of Philadelphia" in the 
same year in which Nuttall's "Genera" appeared, adopted the name given to our plant by Nuttall, and adds his own observations as follows: "This species I have long observed in this neighborhood. It is very like the common rotundifolia, but discrepant enough and sufficiently constant in its character to constitute a permanent species."

The most striking differences which the collector will note at first sight when comparing the two plants are to be found in the texture of the leaves and the length of the petioles. The leaves of $P$. rotundifolia are always of a thicker texture than those of $P$. clliptica; and in the latter the leaf-stallss or petioles are, as a rule, shorter than the leat-blades, although they may occasionally be at least as long, as shown by the old leaf on the plant represented in our plate. In $P$. rotundifolic, on the contrary, the petioles are alway's longer than the blade, and form a very striking feature. Dr. Gray, in his "Ficld, Forest, and Garden Botany," differs from this statement in regard to the length of the petioles, and says that $P$. rotundifolic has "leaves on short petioles," while to $P$.clliptica he attributes "leaves on rather long and margined petioles." But this is cvidently a mistake, as the relative length of blades and petioles, as given in the same author's "Manual of the Botany of the Northern United States," corresponds with our statement in every particular. The elliptical outline of the leat-blades of our species has given rise to the specific name clliptica. This name, however, may mislead the student, as the clliptical form is not confined absolutely to this species, but is also found in some varieties of $P$. rotundifolin. Some botanists think they can see a ready means of distinction in the very acute calyx-lobes of $P$. clliptica, and we have therefore given a view of a flower, showing the calyx, in Fig. 2. But we believe that this character is not constant.

The generic name, Pyrola, was in use, in connection with our plant, long before the time of Linnzus. Salmon, an old English herbalist, says that it was called "Pyrolic by the Latins, on 
account of the resemblance to the leaves and flowers of a peartree"; and our modern authors, as, for instance, Dr. Gray, tell us that the name is "a diminutive of Pyrus, the pear-tree, from some fancied resemblance in the foliage, which is not obvious."

The common name "Wintergreen" came to us from Europe, where it is applied to the $P$. rotundifolia, which is a wellknown plant in the northern part of that continent. Dr. Prior, in his work on the popular names of British plants, thus accounts for it: "Wintergreen is a name adopted by Turner (an old herbalist), from the German IVinter-Griin of the Ortus Sanitatis. The Danish Winter-grört means the ivy, and it is probable this latter, the ivy, is the rightfui claimant of the name, as being so conspicuously green when the trees are most of them bare of leaf." Any one, however, who has seen the Pyrola in early spring will immediately recognize that it is quite as much entitled to the name as the iry. It is often the only living green thing among the dead tree leaves of the previous autumn, and serves admirably well to relieve the monotonous brown color of the forests, where it loves to dwell. The habit which the plant has of growing under oaks and other forest trees is alluded to by Bryant in the following lines from the pretty poem entitled "The Strange Lady":-

"Away into the forest depths by pleasant paths they go,

He with his rifle oil his arm, the lady with her bow,

Where cornels arch thei: cool clark boughs o'er beds of wintergreen, And never at his father's door again was Albert seen."

In reference to the second English name given at the head of this chapter, Dr. Darlington says of Pyrola clliptica that its leaves "are a popular application to sores, as the common name (Shin-Leaf) would indicate." The word "shin," in its proper sense, really applies only to the front part of the lower bone of the leg, or tibia, but by the English peasantry the term "shinplaster" is used for any kind of a plaster, without regard to the part of the body to which it is applied, and hence Dr. Darling- 
ton was justified in speaking of the leaves as a cure for sores of any kind. We cannot, however, find any reference to the healing virtues of our plant in any medical work at our command, and if it really has such virtues it is probable that the early Pennsylvanians received their knowledge of them from the Indians.

The Pyrola clliptica is confined to a comparatively small area, extending in the East from the New England States to the Potomac, and in the West to the Missonri, but it hardly follows that river to its junction with the Mississippi.

The specimen from which our drawing was made was gathered in Massachusetts.

Explanation of the Plate - r. Full-sized plant, as seen at the end of June.-2. Back view of a flower, showing the sharp-pointed calyx-lobes. -3 . Stamen enlarged, showing the pores by which the anthers open at top. - 4. Leaf, showing average proportion of leaf-blade to leaf-stalk. 



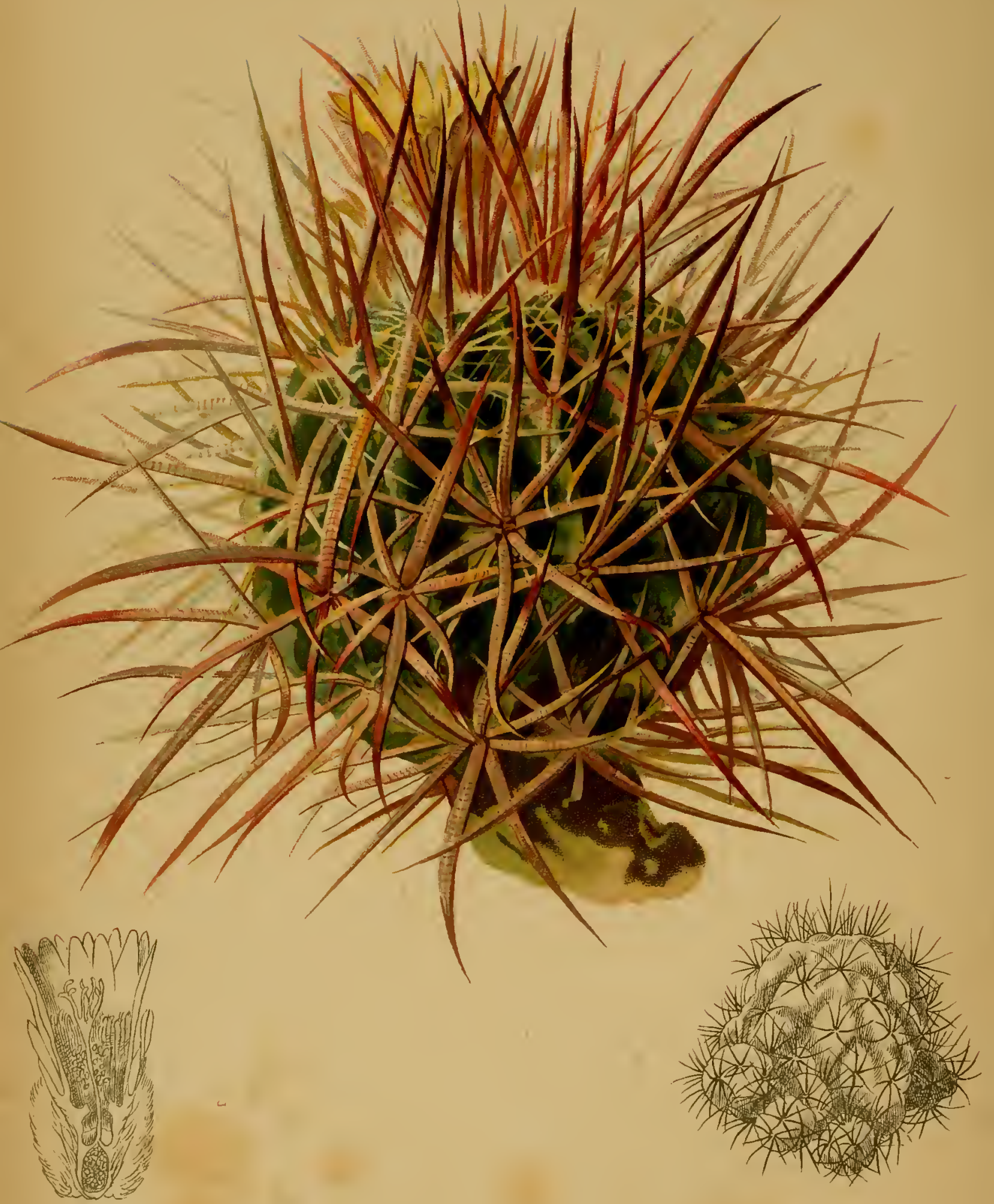




\title{
ECHINOCACTUS POLYCEPHALUS.
}

\author{
MANY-HEADED HEDGEHOG CACTUS.
}

NATURAI, ORDER, CACTACE.E.

Echinocactus Policerhalus, Engelmann and Bigelow - Middle-sized or large, glubose, at last cylindric, sprouting from the base; ribs thirteen to twenty-one, acute; circular areolx bearing eight to twelve stout, compressed, annulated, curved, reddish-gray spines; flowers enveloped in a mass of dense, white wool; petals about thirty, lance-linear, yellow; stigmas eight to eleven, linear; dry berry, full of large, angular seeds. (Brewer and Watson's Botuny of California.) the Cactuses. Pettishly, at first, she gave them coarse, ugly, and repulsive forms; and then, regretting this exhibition of her temper, she endeavored to make amends by adorning them with gorgeously colored and beautiful flowers. The lady's conceit seems to be quite apt and suggestive at first sight; but a more attentive study of the order of Cactacce will readily show that it does not apply in all cases, although these cases may only prove the rule by being exceptions. The species represented on our plate is a good example of one of these exceptions; and we think that, in the faithful copy from Nature given by our artist, no one can fail to see the peculiar beauty of this plant, to which, as a matter of course, we must not apply the same standard of measurement which we apply to ordinary flowering plants. Following up the lady's idea, we might almost imagine that Nature herself had thought the plant quite handsome enough as it is, and that she had for this reason denied it the splendid flowers which are the glory of so many other species of Cactus; for the flowers of our species are comparatively small, and are 
almost hidden by the mass of dense white wool which surrounds them, so that they cannot add much, if anything, to the beauty of the whole structure. If we analyze this beauty, we shall find that the spines are its principal element. The stiff, circular outline of the body is well broken by these thin, tapering, curved, and exquisitely chiselled appendages. One of them, taken singly, would itself be thought a stiff affair; but in their somewhat stellate arrangement, and with their varying sizes and crossing and recrossing lines, they are in excellent contrast with, and impart a peculiar air of lightness to, the solid body from which they spring. The reddish hue of the spines also adds to the effect produced by our Cactus, as it serves admirably well to heighten the gray-blue green of the body.

In a consideration of the character of the Cactuses, and in judging of their bcauty as compared to other plants, we must never forget the surroundings amidst which they grow, and with which they must harmonize. As we leave the wooded and shady lands of the Eastern States, we come to the far West, with its log-cabins, where, in the language of Bryant, -

"The flowery prairies from the door stretch till they meet the sky."

But if we continue our journey even beyond these prairies, we finally come to a region of dry, barren deserts, where everything seems cold and gray, save the hot air that flies trembling upward in the noonday sun. In a place like this, the Cactuses seem just at home, and we must acknowledge that Nature had a very artistic eye when she placed them there. But Nature, in making these plants, was not actuated by artistic motives alonc. In the dry places described, plants like our Echinocactus and its allies are a necessity. They have little growth to make, and as there is but little drain on them by seeds, they need few leaves, and can, therefore, preserve their juices better than other plants. Hence, the stem, to which the globular body of our species corresponds, is the main part, and it is only in the earliest stage of growth that we find traces of leaves. But even 
these are early deciduous. For all nutritive purposes, the bark of such a structure is sufficient to perform the functions usually exercised by leaves. This also accounts for the fact that comparatively little earbon is found in Cactuses, its place being generally taken by a large quantity of lime, which is drawn up from the soil through the roots.

Our Echinocactus polycephalus is one of three entirely new species which were discovered by the botanists of the Whipple Exploring Expedition in 1854 . We quote in full the description given in the report of this expedition, as it will serve to call the attention of the student to the points relied on by botanists in distingnishing the various species of the genus to which this Cactus belongs. Having stated that our species is found on "stony and gravelly hills and in dry beds of torrents from twenty miles west of the Rio Colorado to about one hundred and fifty miles westward of the Mojave," and that it is "found in fruit in the beginning of March," the report continues as follows: "This distinguished species is simple only when quite young; even the small, globose plants show several heads from one base, and older cylindric stems have as many as twenty or thirty lieads, all pretty nearly of the same size. . . . The number of the ribs varies; in old specimens, it is generally twenty-one. Areole about half an inch in diameter and a quarter to half an inch distant from one another [farther apart in our illustration]; floral areole smaller, without the ligneous glandular organs noticed in others. The spines in a young, five-ribbed, living specimen before us are seven radial and one central one. Very soon, however, the four upper, larger spines become central and four lower spines are arranged radially; even on old and fullgrown specimens not more than these eight spines are found. ... Generally, however, two upper ones, weaker and less curved than the two lower ones, make their appearance; and in a few instances before us, we find three to four upper radial spines, the uppermost ones being quite slender. In the field, we noted as many as fifteen spines oceasionally, when, no doubt, seven 
occupy the place of the upper radial ones. The central spines are always very stout, but very different in size. In some specimens we find them one and a quarter to one and three quarters inches, while in others they are two to three and a half inches long. They are nearly straight, or very much curved. The upper one is often one and a half to two lines wide, the lower one the longest. The yellow flowers seem to make their appearance in February, as the fruit ripens in March. The ovary and the fruit are enveloped in dense, pure white, cottony wool, which originates from the axis of the lower sepals, and through which only the dark, reddish-brown spinulose points of the sepals are visible."

All the species of the genus to which our plant belongs were formerly classed as Cactus; but as they became better known, it was found necessary to separate them, and set them up in a family by themselves. The new genus was called Echinocactus, from echinus, a hedgehog, because many of the species are round and spiny like the animal named. There are Echinocactuses, however, which, from their general appearance, might be supposed to belong to other genera, while there are also species in other genera which at first sight might be taken for "Hedgehog Cactuses." The objection might, therefore, be raised that the name is not quite appropriate, did we not know that a name can never fully express character; and the specific appellation, polycephalus or "many-headed," is open to the same objection. The reason for this name is apparent enough from the description quoted; but there are other species, even among the genus to which our plant belongs, which might claim the title with equal justice.

The E.polycephalus is now under cultivation at the Bussey Institute, where it was received from Lower California.

Explanation of tile Plate. - I. Complete single head of a flowering plant. - 2 . I.ongitudinal section of a Hower. -3. Sketch, on a reduced scale, showing the many-headed charactcr of the species. 



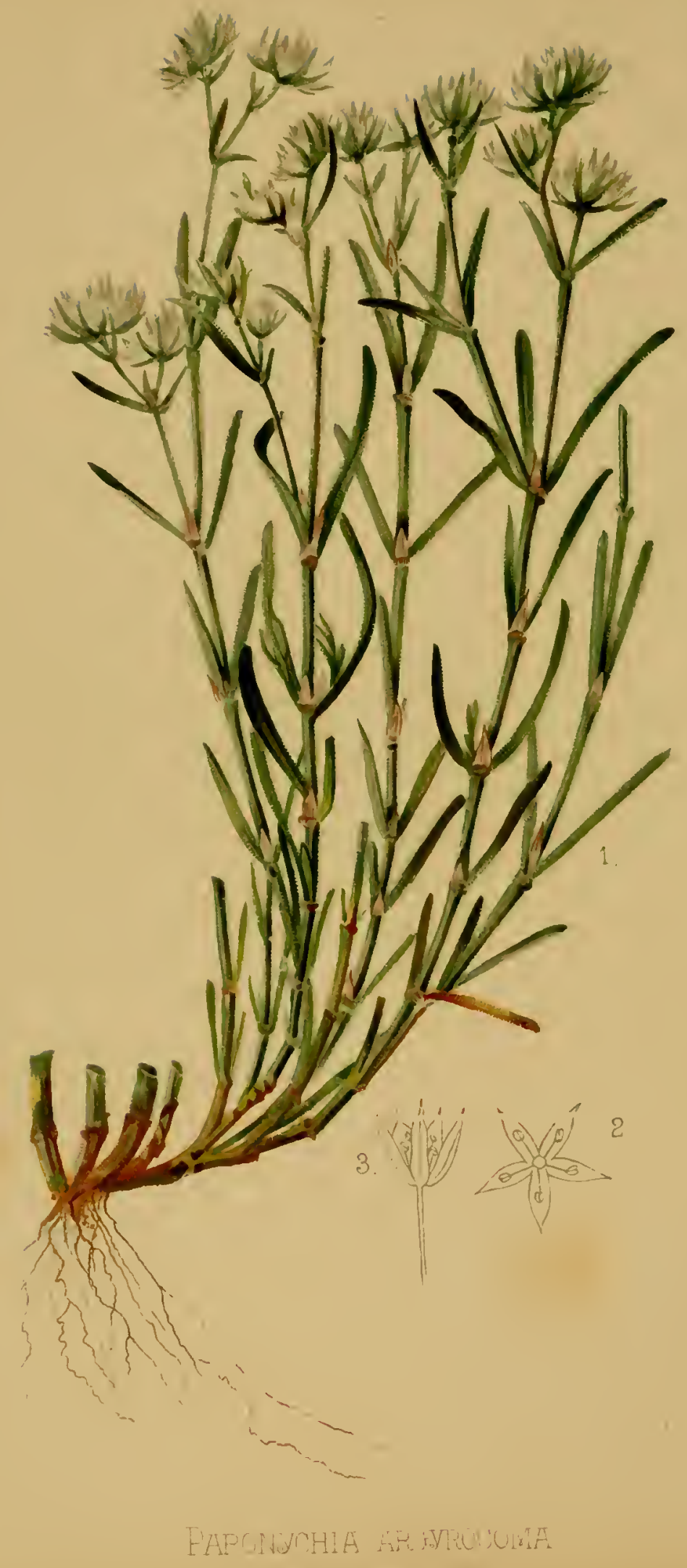




\title{
PARONYCHIA ARGYROCOMA.
}

\author{
SILVERHEAD; NAILWORT.
}

NATURAL, ORUER, CARIOPHYLIACH.A. (IARONYCHIACH.T: ()F LINDLES.)

\begin{abstract}
Paruxichis argirocomi, Nuttall. - Cxspitosc, procumbent, and pubescent; leaves lincar, pungently acute, villous, and nerveless; stipules cntirc; bracts equal with the flowers; cymc dichotomous, cruwded; interior aper of the calyx bearded, exterior setaccously acuminate. (Nuttall's Goncria of North Americun Mlants. Sce also Gray's. Itemual if the Botany of the Northern Linited States, Chapman's Flone of the Southern Linted States, and Wood's Cliss. Book of Botany.)
\end{abstract}

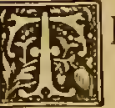

HE lover of pretty wild flowers who has never seen the he has anything very remarkable before him, as he looks at our plate. The difficulty is that it is well-nigh impossible for the artist to do justice to a silver-white plant on a snow-white ground. But in nature the silvery heads of this species are really very beautiful, and when it is considered that there are hundreds of these heads on a single plant, and that, when in perfection, the upper part of the little bush is a foot across, forming a small cushion, sparkling in the sun like real silver, it will be admitted that the aspect must be, not merely pretty, but truly beautiful.

The silvery heads of our species are, indeed, a very striking characteristic, and suggested the specific name argyrocoma, which was given to the plant by Nuttall, and which is Greek for a silvery head of hair. As this particular species of Paronychic has never had a common name that we know of, it has seemed to us that a translation of Nuttall's specific appellation would be quite appropriate, and we have therefore called our plant "Silverhead." We have, however, given also a second 
English name, "Nailwort," at the head of this article, this being, according to Prof. Wood, the common name for the whole genus, although Dr. Gray gives "Whitlow-Wort" as the English generic appellation. These two names are, however, intrinsically identical, as will be seen from the following sketch of the family history of our plant.

One of the most famous, or perhaps the most famous, of the medical writers of antiquity was Hippocrates, who is said to have died in the year 377 B. C., at Larissa, in Greece. He is indeed regarded as the father of modern medicine, and deserves especial recognition as being the first physician of whom we have any knowledge, who taught that attention to diet in sickness is one of the best medicines. Hippocrates mentions a plant by the name of Paronychic as a particularly effective remedy for certain painful diseases of the nails and joints of fingers and toes, called felons or whitlows. Some authors have supposed the plant spoken of by Hippocrates to be identical with some species of the genus to which our Silverhead belongs, although this is by no means beyond a doubt. Several of the old herbalists thought that the true Paronychic of Hippocrates was a Saxifrage. Others, again, conjectured it to be the little carlyflowering Draba verna, which is called "Whitlow-Grass" to this day; while Sibthorp, finally, who made a special study of the plants of Greece and of their ancient history, thinks it most likely that Illeccbrum Paronychio is the plant, although he adds that even this opinion is still open to some doubt. But however this may be, the herb of Hippocrates can hardly have been one of the species of the present genus Paronychia; for that careful old physician generally had some reason for the medicinal virtues which he attributed to the remedies he employed; and these modern Paronychias, beyond a trace of astringency, which, according to Dr. Lindley, pervades the whole order, seem to be destitute of any very marked medicinal properties. This slight astringency, however, may be worth noting, and is perhaps capable of being turned to good account. 
Quite recently there has appeared on the market an article known as "Arabian Tea," which is used not merely as a beverage, but also as a tonic in cases of weak digestion. It is used quite extensively in France, where it is imported from Algiers. This "Arabian Tea" is the Paronychica argcntca, a plant which is closely related to the Silverhead described in this present chapter. Possibly our plant may make as good a tea as the Algerine plant, and it would be worth while, at all events, to give it a trial.

The genus Paronychia, which was created by Tournefort as far back as the year I 700, and now finds general acceptance among botanists, is the type of the order Paronychiacer, and is a very interesting one to students of botany. The plants grouped together as Paronychiacca are so closely related in their structure to the plants of other orders, that it is not very easy to define the order itself, and hence there is considerable difference of opinion in regard to it. Dr. Lindley, in the "Vegretable Kingdom," remarks that the Paronychiacce are "very near Purslanes (Portulacacea), Amaranths (Amaranthacca), and Cloverworts (Caryophyllacea), from which they are distinguished with difficulty. From the latter their scarious stipules will separate them, and there is scarcely any other character that will. From Purslanes they are best known by the position of the stamens before the sepals instead of the petals (sce our Fig. 2), and by the number of the sepals." Sachs, in his "Text-Book of Botany," does not regard the characters as sufficiently distinctive to form a separate order, and therefore classes these plants as the section Paronychica of his family Caryoplyyllca. None of our American authors, Dr. Gray, Prof. Wood, or Dr. Chapman, recognize the order Paronychiacee, and in their works our species must therefore be looked for among the Caryophyllacece

The close affinity of some natural orders often worries the student of classification, who values more definite lines of distinction; but it is very welcome to the careful student of plant- 
life, who loves to trace out close relationships, and is never so much annoyed as when the connecting links between the various groups of plants are lost.

The collector of wild flowers will find the Silverhead to be one of the precious jewels of Flora, which she takes very good care not to scatter around too freely. Nuttall, describing our species in 1818 , says that it was then known only "on rocks in the mountains of Upper Carolina, and on the banks of French Broadriver in Tennessee, near the thermal springs"; and the most recent authority in southern botany, Dr. Chapman, simply says, "Mountains of Georgia and North Carolina." Dr. Gray locates our plant in "slides in the Notch of the IVhite Mountains, N. H., and bare summits above; Alleghany Mountains from Virginia southward"; and according to Prof. Wood it is found in the "White Nountains, N. H., in the gorge behind the Willey House (Chapman), and in the Alleghany and Cumberland Mountains." Its time of flowering is given as July by Dr. Gray and Prof. Wood, but it will probably be found in bloom later than this, and indeed Dr. Chapman says that in the South it blooms from July to September.

The specimen from which our drawing was made grew at the Bussey Institute, under the care of Mr. Jackson Dawson, the head gardener of the Arnold Arboretum.

In the paragraph quoted from Dr. Lindley's "Vegctable Kingdom," the position of the stamens "before the sepals instead of the petals," is spoken of, and the reader, on referring to Fig. 2 on our plate, may have becn surprised at finding only the calyx represented. The petals in all the species of Paronychia are exceedingly minute, and in our Silverhead they are mere teeth between the stamens, so that the flower might easily be taken for an apetalous one. 


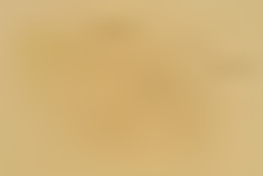


VOL. II

Plate 35

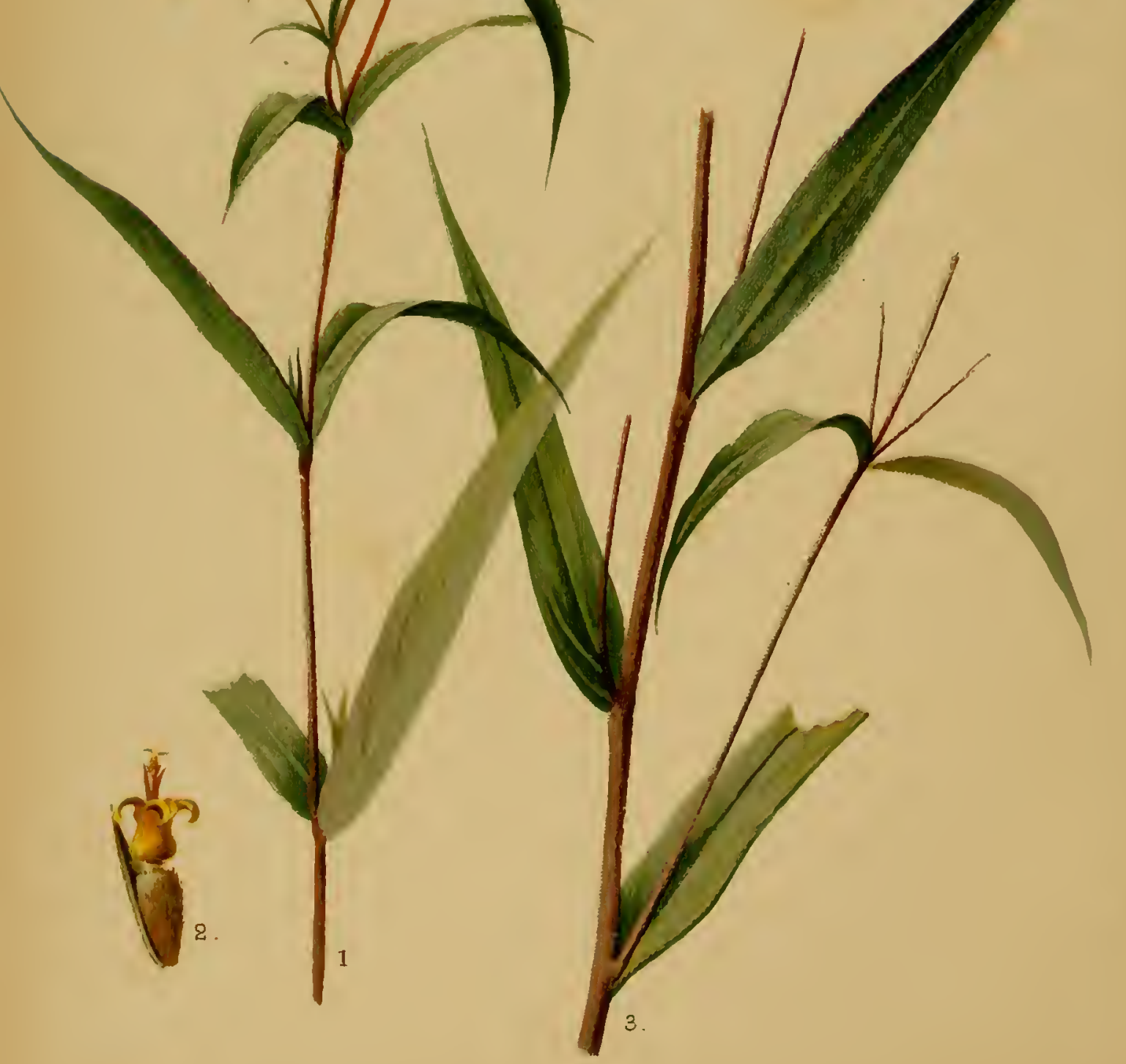

Gymnolomia PoRTERI 


\title{
GYMNOLOMIA PORTERI.
}

\author{
STONE-MOUNTAIN STAR.
}

NATURA1, ORDER, COMPOSITE. (ASTERACLAT (IF LINDLEV)

Granolomer Porteri, Gray:-Rough, with short, scattered hairs; stem paniculately branchecl ; leaves lanceolate, entire, narrowed at each conl, fringed at the basc; exterior scales of the involucre linear, as long as the clisk; the interior shorter, rescmbling the chaff of the receptacle; rays seven to nine, longer than the disk; stem two to three feet high. (Chapman's Filori of the Southern Linited Statis, uncler the name of Rudleckia? Forteri.)

HE plate which accompanies this chapter is probably the first illustration ever published of the Gymnolomia Porteri, a plant which, although it is a native of one of the older settled States of the Union, will not be found noticed under this name in any popular work on American botany. In Dr. Chapman's "Flora," from which we have taken our description, the plant is noted as Rudbcckia? Portcri; and the question-mark affixed to the generic name proved to be a wise precaution, as Dr. Gray, who first named the species, found it necessary, on further examination, to remove it to the genus Gymnolomia, which has its principal home in Bogota and New Granada. This latter genus was established by Humboldt, Bonpland, and Kunth in their "New Genera of American Plants," published in Paris during the first quarter of this century. Dr. Gray deseribes our present species more particularly as Gymmolomia Porteri in the "Proceedings of the American Academy of Arts and Sciences" for IS76, suggesting, at the same time, that it is probably identical with Heliomeris, another American genus, established by Nuttall. Our species, however, differs widely from Heliomeris in the form of the corolla of the disk florets, 
which is slenderly campanulate in the latter genus, while in Gymnolomia, as illustrated by our plate (see Fig. 2), it is short and contracted towards the apex, so that its widest part is at the base.

No plant of the genus Gymnolomia was known to exist in our country till I $S_{46} 6$, when our species was discovered by Rev. Thomas C. Porter, the professor of botany at Lafayette College, Easton, Pa. So late a discovery of an entirely new genus, in a part of the country so well explored as the old Atlantic States are supposed to be, is quite remarkable, and we may, thercfore, be pardoned for giving a detailed account of the event from a private letter from Dr. Porter himself, addressed to the writer of this in $1 S_{77}$. "On the 19 th of July, $1 S_{4} 6$," writes Dr. Porter, "I joined a party consisting of Dr. Joseph Le Conte (now of the University of California), and a few ladies, for a six weeks' summer tour through Northeastern Georgia, at Graves' Hotel, at the foot of Stone Mountain, De Kalb County, twelve miles east of Atlanta. This celebrated mountain is a huge, isolated mass of granite, fifteen hundred fect high, on the north side perpendicular for onc thousand fect, very steep on the south and east sides, and sloping on the west, where it is wooded half-way up. The bare summit was crowned with a square wooden tower (burned down cluring the war), over one hundred and sixty feet high. Its keeper, strange to say, bore the name of A. Cloud. As the top of the tower commanded a view of vast cxtent, our party started out at two oclock the next morning in order to reach that clevated position, in time to see the sun rise. When day darned, I noticed on the upper part of the mountain and around the tower, in flat places and depressions of the rock, where a scanty soil had accumulated, clumps of stunted bushes, on the borders of which grew, in considerable abundance, a helianthoid plant, about two feet high, with gay, yellow flowers. It was collected and sent to Dr. Gray, who published it in his 'Plante Fendlerianx,' under the name of Rudbcckia? Portcri. When gathered, I observed that the fresh roots exhaled a strong, peculiar odor." 
The generic name Gymnolomia, which, as we have before noted, was given to certain South American species in IS 20 by Humboldt and his associates, is cloubtless derived from two Greek words, signifying "a naked border," and refers, perhaps, to the circumstance that the florets have no pappus or calyx, either in the shape of bristles or scaly appendages, on the summit of the achene (see Fig. 2), beneath the corolla.

In the Gymnolomia Porteri the receptacle is provided with scales, - one scale for each floret; and although this is rather a common character in the plants belonging to the Composites, and especially in the allies of the present species, the nature of the scales in our plant is, nevertheless, worth noting. As a general rule, these scales are chaffy and almost colorless, while in the Gymuolomia Portcri, as shown in our Fig. 2, they are colored; and this gives a chance to the student to trace their relationship to the involucral scales, and through them to the leaves, and at the same time offers a clew to the true relationship of the Composites to other classes of plants. A few moments' consideration will convince us that all plants, the Composites included, are formed upon one primordial plan, which plan is simply modificd by the laws of acceleration or retardation. Let us imagine that all flowers procecd from axial buds, or, in other words, from the bases of the leares, above the connection of these latter with the stem or axis, each bud having its own leaf to start from. Usually, the stem is lengthened, or, as we say, accelerated in its growth, so that the leaves are scattered upon it, each one being situated at some distance from its next neighbor. In such a case, the flowers are, of course, also scattered along the stem, and, from their position in the axils of the leaves, they are said to be axillary. But if we now suppose this growth of the stem to be suddenly checked, so that the distances between the various leaves are considerably diminished, and the leaves themselves stunted in their growth, we shall have the flowers in a raceme; and if we continue this diminishing process still further, until the stem is so reduced that the flowers are 
all drawn spirally together as close as they possibly can be, we shall have just what occurs when Nature forms the "compound flower." Each floret in the head of a Composite, therefore, represents a flower on the stem, and the scales which often accompany these florets are simply the leaves or the bracts, from the axils of which the flowers start. Our Gymnolomia is very well fitted to prove the truth of this theory, as the scales of its receptacle, which latter, as we now see, is nothing but a contracted stem, have retained more of their leafy character than usual.

Since our plant was first discovered by Dr. Porter, it has been diligently looked for in the South, but it has never been found elsewhere than on Stone Mountain, in Georgia. This is a curious fact, and stimulates speculation. We know that, in the course of ages, some species die and others are born. Conceding this to be a fact, it is always interesting, when we find a plant which is unlike any of its neighbors, to inquire whether it is a new creation which originated on the spot where it was found, or whether it is the last of a race which is dying out. In this case, arguing from the fact that our species has a number of relatives in South America from which it is separated by a vast distance, it is reasonable to suppose that the G. Portcri is the remnant of an old family, which, owing to some favorable circumstances, has been preserved in the small spot where it is found to tell the disastrous tale of the destruction of its relatives.

"But what is the common name?" asks the wild-flower collector. As it is an asteraceous plant, - a "Starwort," as Lindley would say, - suppose we call it "Stone-Mountain Star"?

The plant from which our drawing was made was grown by Mr. Jackson Dawson, in the gardens of the Bussey Institute.

Explanation of the Plate. - I. Flowering branch. - 2. Eularged florct, with the scale at the base of the achenc. - 3. Lower portion of a flower-stalk, showing its brauching character. 



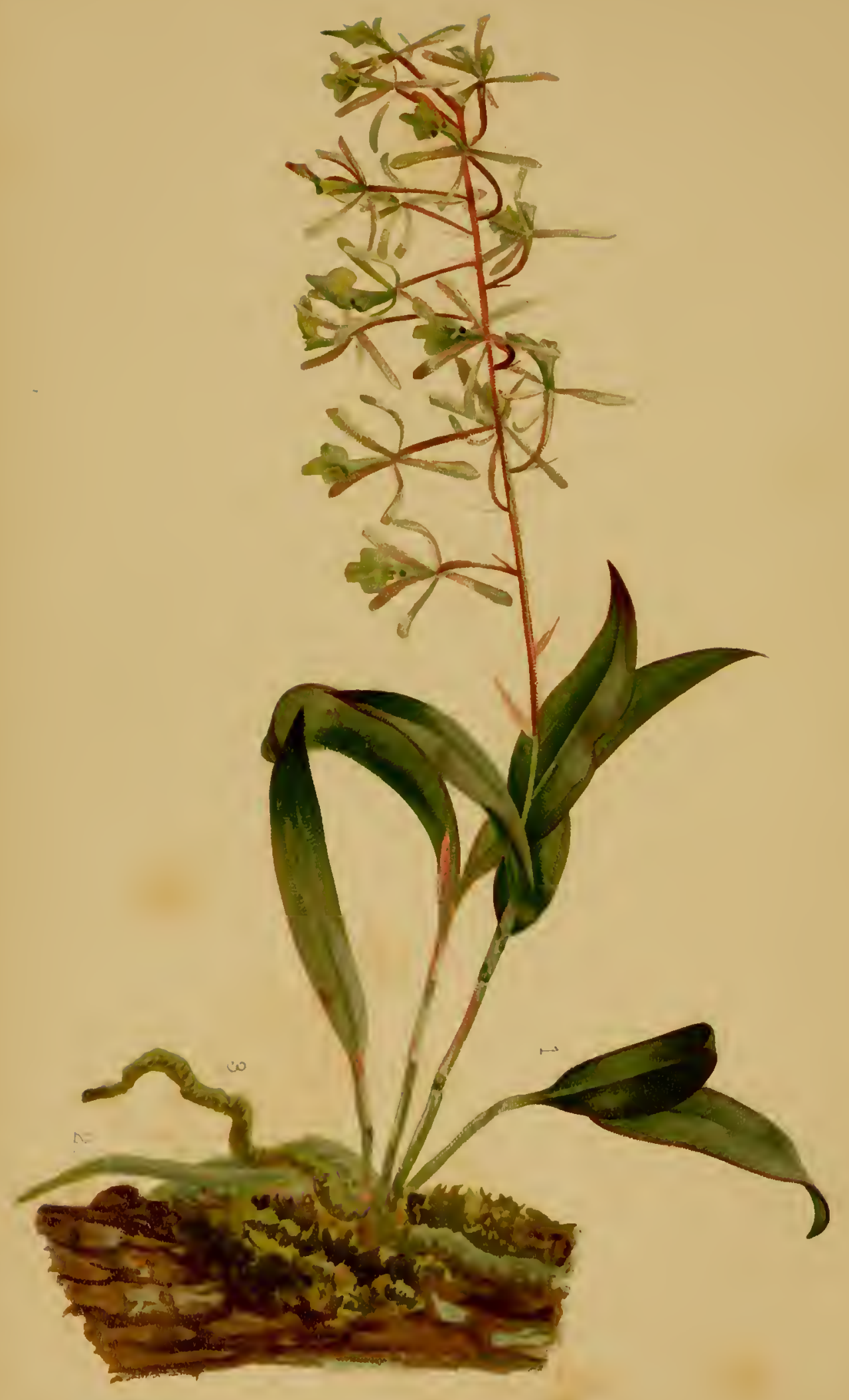




\title{
EPIDENDRUM CONOPSEUM.
}

\author{
BARTRAM'S TREE-ORCHIS.
}

NATURAL ORDER, ORCIIIDACEN.

EPIDENDRUM Conopseun, Aiton. - Scape few to many-flowered; leaves one to three, coriaceous, lanceolate, acute, spreading; bracts subulate, the lowest somewhat leafy; sepals spatulate, obtuse, with revolute margins; petals linear-spatulate, obtuse; lip two-tubercled at the base, three-lobed, the lateral lobes rounded and crenulate, the midcle one notched at the apex, the claw wholly adnate to the slightly margined column; scape two to eight inches high; leaves one to three inches long; fowers four to five lines long, green, tinged with purple. (Chapman's Flora of the Southern Unifed States. See also Wood's Class-Book of Botany.)

HE remarkably curious family of Orchidacea may be 20.0 divided into two large classes, - the terrestrial and the epiphytal. The terrestrial Orchids are those which grow on the ground, while the epiphytal species, as the Greek adjective implies, grow upon some other body, and derive their nourishment from the air. The Orchids of the latter class, which are also known as "air-plants," are confined to the warmer parts of the earth, while those of the first class extend to the temperate regions, and penetrate even into the Arctic Circle. The terrestrial Orchids are very well represented in our country; but of the "air-plants," only a few species are known here, and. these few have been discovered within a comparatively recent time. The subject of the present chapter, Epidcndrum conopscum, was the first of its kind found within the limits of the United States, and its discovery is due to William Bartram, the son of John Bartram, the great patriarch of American botanists. William Bartram met with our species in Florida, while on an expedition in search of the natural products of that region, undertaken at 
the suggestion and at the expense of that celebrated lover of plants, Dr. John Fothergill, of London. The expedition, which occupicd five years, started in 1772 , and our plant must have been one of Bartram's earliest discoveries, as we find it reported by Aiton, in "Hortus Kewensis," as introduced into Dr. Fothergill's garden in 1775 .

The earliest name by which our plant was known seems to have been Epidendrum Magnolia, under which designation it is enumerated by Muhlenberg, a celebrated Pennsylvania botanist, in his "Catalogue of American Plants," published in Lancaster, Penn., in 1813. Some years later, Aiton named our species Epidcudrum conopsum, and this name prevailed, in accordance with the usages of botany, as it was the first one published with a description showing the distinct character of the plant. Muhlenberg's name, however, is still met with in many books, and we may, therefore, pause for a moment to explain its meaning. Our plant received this name because it had been found on the Magnolia grandiflora by its discoverer, William Bartram, and because it very generally occurs on that tree, although it is likewise frequently found on others. The fact that it grows on other trees seems to have been discovered by Dr. Baldwin, who was the first botanist of the Long Exploring Expedition, but who died at Franklin, Mo., before the expedition was well under way. In a letter to Dr. Muhlenberg, dated Jan. 7, I 8 I 3 (as stated in Darlington's "Reliquixe Baldwinianæ," but the year should evidently be i 8 i 4), he mentions, as an occurrence of marked interest, that on Dec. I I he "found the Epidendrum Magnolice on a species of hickory (Fuglans),"- the hickory at that time not having been transferred from Fuglans, or the true walnuts, to Carya, with which it is now classed, - and he goes on to say: "Enclosed you will find a specimen of Epidcndrum Magnolia, taken this day [Jan. 7, 1914] from Mclia Azcdcrach, where it had been transplanted last spring. It is remarkable that it has continued to flower all the winter on the Milia, while in the woods no flowers are to be found." The Mclia Azcderach is an intro- 
duced tree, known throughout the South as "Pride of India," or "China-Tree," and the transplanting of the Epidendrum to this foreign tree, in a locality where the Magnolia is so common, can have had no other object than to test the question whether or not the plant would do well on any kind of a tree.

During and before Muhlenberg's time the idea seems to have been prevalent that the Epidcndrmm and some of its allies were parasites. Dr. Pfeiffer, in his "Nomenclator Botanicus," says the name Epidcndrum, signifying "upon a tree," was given to this plant by Linnæus in I737, "quia sit herba parasitica" (because it is a parasitic herb). A true parasite, however, is a plant which is not only supported, or held up by a tree or other plant, but which actually draws some of its nourishment from the organism upon which it grows. But this is not the case with our species. It is, indeed, supported by the tree on which it grows, but only mechanically, as it gets most of its nutrition from the atmosphere. We say purposely "most of its nutrition," for although the Epidcndrums are called "air-plants," it is not strictly accurate to say that they draw wholly upon the atmosphere for their food. If a quantity of these plants be burned, certain mineral salts will be found in the ashes, which are not known to exist in the atmosphere, and of which it is not yet quite clear how the plants become possessed of them.

Additional evidence that our Epidcndrum conopscum is not a true parasite is furnished by the manner in which the plant can be kept under cultivation. All that is necessary is to tie it to a block of wood, together with a little moss, and to hang it up in a convenient place, where it can get water occasionally, as any other plants that may be around it are watered. In winter it can be hung up in a green-house, or in a window in any room or place where it will be protected against the frost. The writer of this has found that the plant will thrive lustily under such circumstances.

According to Prof. Wood the Epidcndrum conopsenm grows in damp woods, from South Carolina down to Florida, and 
thence westward. It has no common name, that we know of, and we have, therefore, called it "Bartram's Tree-Orchis," in commemoration of the name of its first discoverer. Our plate shows the curious manner in which the plant grows, not pointing up towards the sky, as other plants are wont to do, but shooting out laterally, almost at a right angle with the tree or other object by which it is supported.

We may add, in conclusion, that the name of the genus will sometimes be found spelled Epidendron. Linnæus, who, as we have seen, named the genus, originally used the prevalent orthography, Epidcndrum; but in his "Hortus Cliffortianus" he adopted the more elegant, and perhaps more correct form, Epidendron. Good writers often follow hin in this, but the general rule is to take the name as first published with a description, and, unless for some very cogent reason, it is not advisable to make a change. With flowers, more than with anything else, "a name is but a name," and some of the earlier botanists, as, for instance, Milne, in his Botanical Dictionary, have written whole chapters to show that names which really have no meaning at all are much less misleading than those which are more expressive.

Explanation of the Plate. - I. The complete plant attached to the bark, and flowering from the growth of last year (from a plant in the Arnold Arboretum of the Bussey Institute, under Mr. Dawson's care). - 2. Old aerial root, showing a crimped epiderm. 3. Newly forming aerial root. 



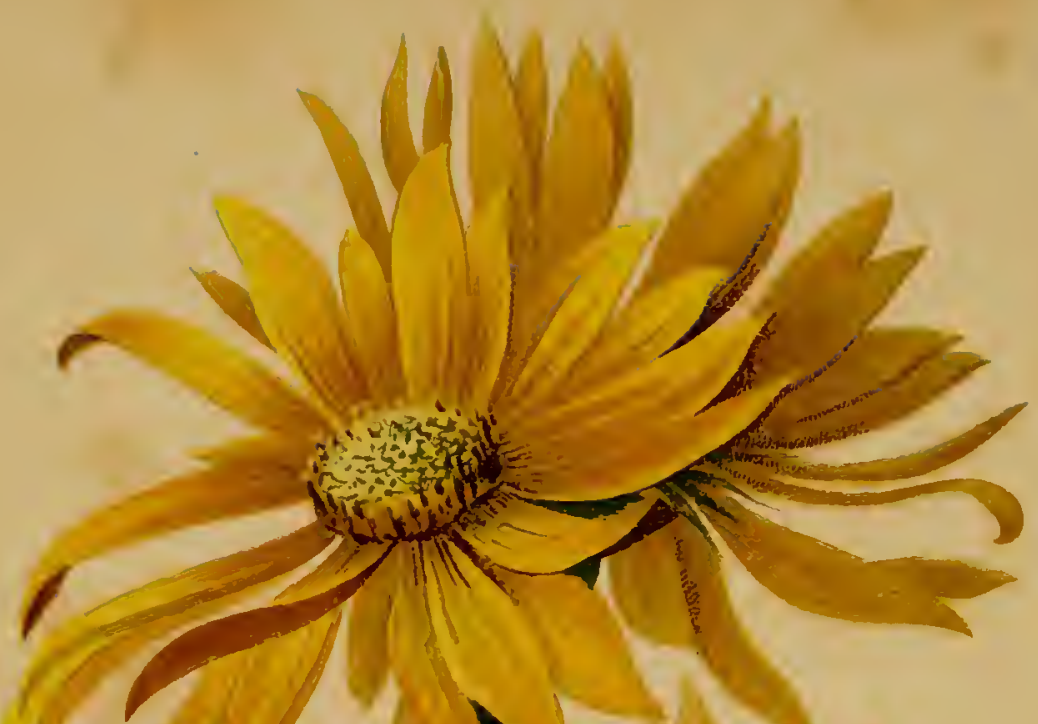




\title{
HELIANTHUS MAXIMILIANI.
}

\author{
MAXIMILIAN'S SUNFLOIVER.
}

NATURAL ORDER, COMPOSITE. (ASTLRAC1:.T: OF LINILEY.)

IIELINTIrUs Maxmoldini, Schrader. - Cauline leaves opposite, those of the branchlets alternate, lanceolate, sub-serrate, scabrous, often narrowed into a short petiole; involucral seales lanceolate-linear, acuminate, somewhat hispid. (De Candolle's Prolromus Systematis Nituralis Regni Iegctabilis, l'art VII. Sec also Torrey and Gray's Flona of North Ameriat, Vol. II.)

ELIANTHUS is the Sunflower, and the species to
Maximiliani-in honor of Prince Maxinilian von IViedNeuwied - by Henry Adolph Schrader, a very industrious botanist of Göttingen, who flourished in the carlier part of this century. Prince Maximilian was a naturalist of distinction, and travelled extensively in America, visiting Brazil in $1815^{-1} 7$, and the United States some years later. The results of his researches he gave to the world in a series of magnificent volumes, two of which, accompanied by an atlas, and published at Coblenz in I $83 S_{-43}$, are devoted to his "Journey Through North America," by which title they are known. It was while travelling in Missouri that the prince, according to De Candolle, discovered the flower afterwards named for him.

Our species does not seem to be very well known to American botanists, as it is seldom recorded as having been met with. It is not mentioned by any of the writers who treat of the botany of the country lying east of the Missouri and Mississippi Rivers, and it is probably confined to the lot and dry regions extending west of the Mississippi. Prince Maximilian, De Can- 
dolle tells us, found it along the river-courses and in grassy places in Missouri. In Lieut. Whipple's report of an exploring expedition for a railroad route to the Pacific, along the thirty-fifth parallel, it is recorded as having been found in prairies and ravines on the Canadian River, and as flowering in August. In Engelmann and Gray's "Plantze Lindheimerianz," it is noted as growing in "prairies, margins of woods, and deserted fields, common from Houston to the Colorado, flowering in October and November"; and Mr. Wright, in his travels in Texas and New Mexico, collected it on the San Pedro River. Lawrence, Kansas, where our plant was found by Prof. Snow, seems to be about its northern boundary. From these different localities the student of botanical geography will be able to form a tolerably fair idea of the limits within which the Helianthus Maximiliani grows.

The plant from which our drawing was made was given to the writer by Prof. Thurber, and it seems greatly to enjoy the care which it receives under cultivation. Maximilian's Sunflower is indeed a very handsome plant for the garden, as its narrower leaves take away from it the coarseness of appearance which is an unpleasant feature in some of the other members of the genus. The gray tint of the leaves and stems is also quite peculiar among Sunflowers, and but few people would recognize it as such before the blossoms have opened. Engelmann and Gray, in the "Plante Lindheimerianx," before quoted, refer to this tint as a special characteristic, and say that the species is "well distinguished by the cinereous (gray) roughness of the stem and of both surfaces of the lanceolate attenuate-acuminate leaves." The same authors add, however, that the plant becomes much less rough by cultivation. They also mention a variety from the Brazos and the Colorado, which has the leaves much rougher than the typical form.

In studying the botanical characters of the Composita, the little florets of which each head is composed are of great importance. To help the student we have given in Fig. 3 an 
enlarged drawing, which will not only show the form and relative position of a floret of Helianthus Maximiliani, but may also serve to exhibit the generic character of Hclianthus as a whole. In many of the plants classed together as Composites the form of the receptacle, or in other words of the mass on which the florets are placed (see R in Fig. 3), is of generic importance. We see here that it is conoidal or "convex," as Dr. Gray describes it. The long, slender achene or ovary, which finally forms the seed (A, Fig. 3 ), is also shown in our drawing, with three of its four angles visible; and on the upper part of the achene we may notice the "pappus (P, P, Fig. 3) of two thin chaffy scales, corresponding with the outer and inner angle of the achene." Then we have the tube (T) with its slender base, the ampliated base of the upper and thicker part of the corolia, and the recurved lobes; and, protruding from the mouth of the corolla, we see the tube formed by the united anthers $\left(A^{\prime}\right)$, through which the style with its two stigmas (S) has pushed its way. The shape of the tube of the corolla is not noted in our tcxt-books, but is very characteristic. Each floret is also surrounded by chaff on the receptacle, but this we have had to omit, as otherwise we could not have shown the achene. Compound flowers (Compositc) have a great general resemblance, and the student is therefore likely to be puzzled in trying to distinguish the various genera and species. But when examined in detail, as we have just examined the floret of our H. Maximiliani, they show points of great dissimilarity; and there are few orders which more thoroughly arouse the enthusiasm of the botanist than that of the Composite, after he has once learned to understand them.

The generic name, Hclianthus, is from the Greek, and literally means "Sunflower." According to Milne, Linnæus was induced to select this name by the "obvious resemblance" of the large flowers "to the disk or body of the sun, the florets at the circumference resembling the rays of that luminary." The ancients also had a Sunflower, known as the "Turn-Sole" in 
English, although the name is derived from the French, and the fables and fancies connected with this flower have become mixed with our own species, the common Sunflower, which, however, like the whole genus, is specifically American.

"The Sunflower turns to her gorl, when he sets,

The same look which she turned when he rose,"

sings Noore: and many people, therefore, believe that the Hclianthus really follows the sun's movement with its head. It is amusing to note in this connection how eminent writers will sometimes endeavor to explain on "philosophical principles" the reason of things that never happen. The writer of this has now before him an old work, entitled "The Compleat Florist," published in I706. In this book we are told that "the flower of this plant turns itself always towards the sun, because, it being heavy, and its stalk heated and softened on the side next the sun, it must naturally incline that way." Our author's remarks are interesting, and his reasoning is certainly not more out of the way than much of that which is brought forward in connection with the philosophical questions of our day.

According to the myths of the ancients the Sunflower known to them was originally a beautiful young girl named Clytia, who fell in love with Phœbus, the sun-god. In the hope of seeing Phobus more frequently, she journeyed to the Isle of Rhodes, but finding that the god did not return her love, and that her case was hopeless, she died of grief, and was changed to a Sunflower. We repeat, however, that these old stories have no immediate connection with Hclianthus, as the whole of this genus is strictly American, and was, therefore, wholly unknown to the ancients.

Explanation OF THE Plate. - 1. End of a flowering branch. - 2. Lower portion of a stem, with leaf. -3 . Enlarged floret and receptacle. - 4. Portion of the edge of the leaf, showing, at $S, S, S, S$, its subserrate character, with the spaces between minutely serrulate. 


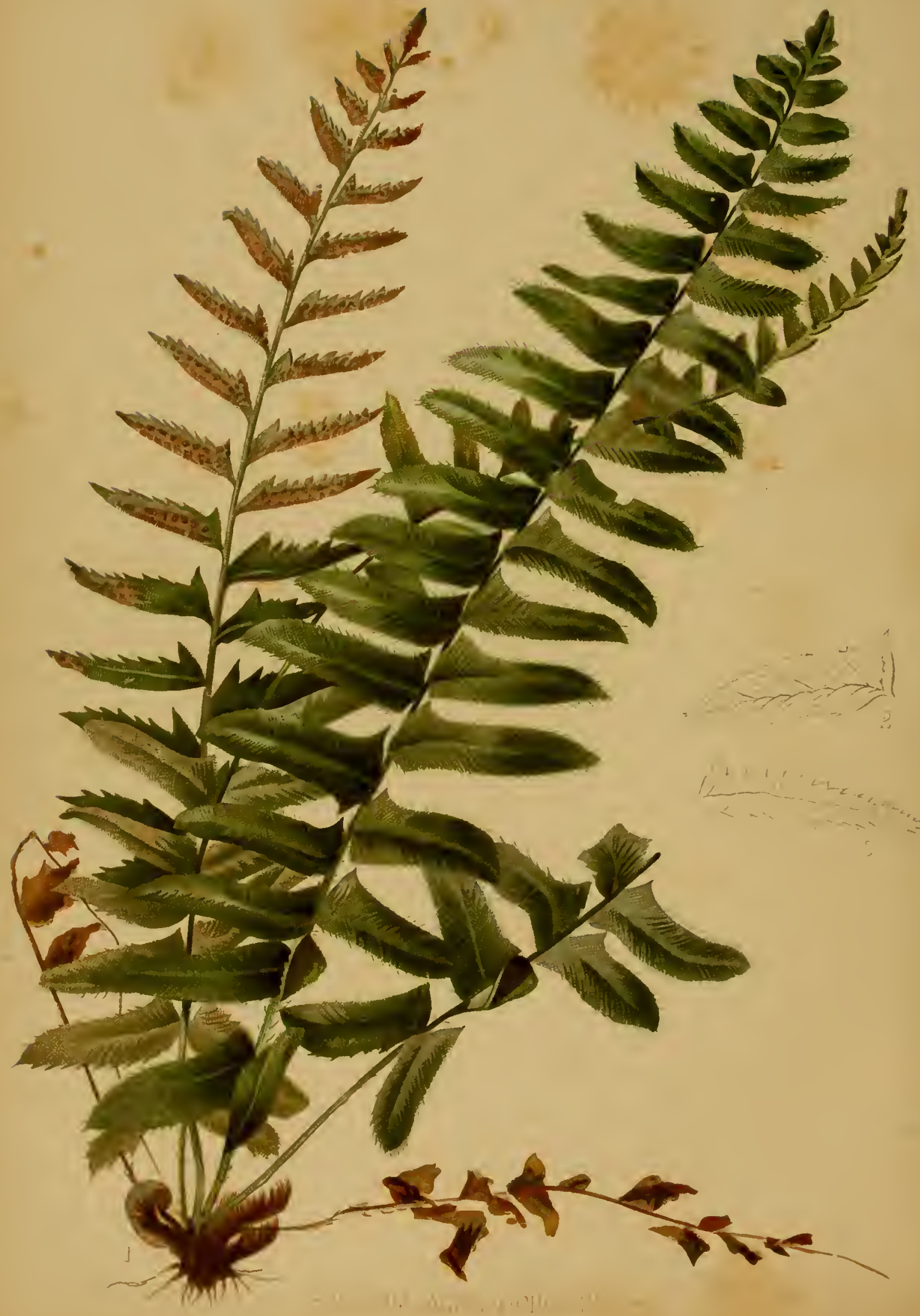




\title{
ASPIDIUM ACROSTICHOIDES.
}

\author{
CHRISTMAS SHIELD-FERN.
}

NATURAL, ORIER, FILICES. (POLYPODIACEA.)

\begin{abstract}
Asiriduar ACRosticioides, Swartz. - Frond lanceolate (one to two and one half fect high), stalked; pimne linear-lanceolate, somewhat seythe-shaped, half-halberd-shaped at the slightly stalkel basc, scrrulate, with appressed bristly tecth; the fertile (upper) oncs contracted and smaller, bearing contiguous fruit-dots near the midrib, which are confluent with agc, covering the surfacc. (Gray's Alanual of the Botany of the Aorthorn Linited Statis. Sec also Wood's Class-Book of Botuny, Chapman's Flort of the Southirn United Stutes, Williamson's Ferus of Rentucky, and Eaton's Ferns of North Anerica.)
\end{abstract}

HE earlier botanists regarded the spores of ferns as 13. seeds, and as they had noted that there were flowers prior to seeds in other plants, they supposed that in ferns also these seeds must be produced by some similar, although hidden, flowering process. Hence we have the many allusions to secrecy in connection with ferns in the writings of the authors of by-grone times; and even Linneus so far recognized this popular impression as to institute the class Cryptogamia, that is to say, a class comprising plants which contract "hidden marriages." Even to the commencement of the present century the manner in which the spores are produced was considered one of the great mysteries of vegetation. A popular French author of the last century has the following remarks on this subject: " $U p$ to this day botanists have in vain studied this plant (that is, the fern), which seems to conceal from the most searching cxamination the secret of its flowers and fruit, confiding to Zephyr alone the invisible germs of its young family. That deity delights in forming of its long tresses the sombre veil concealing the mouth of some cave, where the solitary naiad has slept for ages. Sometimes 
bearing them on his wings he fixes them like verdant stars on the summit of some old castle, or, disposing them in light festoons, adorns with them the refreshing and shady spots which shepherds love. Thus it is that this wild plant conceals its secret origin from the most penctrating eyes, but anxiously replies with benefits to the curious search of the permitted inquirer."

At the present time, indeed, we know much more about the secrets of the fern than our ancestors did; but still it must be said that even now botanists are not quite agreed as to what they sec, at least in so far as the classification of ferns is concerned. Most American botanists regard the species to which this chapter is devoted as an Aspidium, but John Smith, a noted English pteridologist, that is to say, one versed in the knowledge of ferns, still regards it, as Michaux did, as a Nephrodium. Roth, a German botanist, who flourished about the end of the last century, and was one of the first to point out the value of the indusium (the membrane which covers the fruit-clots or sori in most ferns) as a character in the classification of ferns in determining genera, placed our plant in the genus Polystichum, which he had himself instituted. Dr. Gray, however, merely regards Polystichum as a subdivision of Aspidium.

When the value of the indusium had come to be fully understood, the species here illustrated and its allies were classed together in the genus Aspidizm, owing to the peculiar character of the indusium, which at a certain stage in the life of the plant has the appearance of a little shield. In the earlier condition of the fertile frond the edge of the circular indusium which protects the sporangia, and which is simply part of the cuticle of the frond, adheres closely to the pinna (see Fig. 3); but later in the season these sporangia or spore-cases burst through the indusium at all points of its circumference, leaving its membrane attached to the pinna by the middle only, thus giving it the shape of a little umbrella, or, as the Greek name Aspidion implies, of a little shield. In all ferns, indeed, the spores are formed beneath 
the cuticle, but in some the pressure and final rupture is not cqual on all sides, as it is in Aspidinm, and hence we have many other forms of indusia, such as moon-shaped and the like, which are taken into account in the determination of genera.

Mr. Williamson, in his "Ferns of Kentucky," calls Aspidium acrostichoides the "Christmas Shield-Fern"; and this name is very characteristic, as our species is certainly better known by the pcople generally at the Christmas season than any other fern native to our country. In places where this fern abounds it is often the only green thing which shows here and there above the snow, and then it gives a peculiarly rich appearance to a woodland winter scene. Its gayest season, however, is October and November. Along the Wissahickon, near Philadelphia, where it is peculiarly rich and abundant, it of ten forms the chicf element in that famous wild scenery. It is not unfrequent to find places here where in the past the ground has been washed out into numerous little hills and hollows; but the ferns, with other plants, have taken such complete possession of these places as to clothe their sides, and indeed the whole surface, entirely, leaving only a little brown earth or an occasional rock to crop out here and there, all else being one luxuriant mass of regetation. The rich brown under surfaces of the fertile fronds make a pleasant contrast with the green of their upper surfaces, but the chief aid in the beautiful picture comes from the fallen crimson, orange, or yellow autumn leaves of the deciduous trees under which the Christmas Shield-Fern loves to grow. To these are often added the pretty scarlet berries of the Mitchella repens, or Partridge Berry, and, if the observer can time his visit right, the golden rays of the setting sun. An eight-mile walk on the Wissahickon, taken one autumn evening especially to see an extra beautiful exhibit of the Christmas Shield-Fern, is one of the many pleasant recollections of the writer's life.

No doubt such little spots of beauty as those just described are common in many other places, for this fern is rather widely distributed over the eastern portion of the United States. It 
was at one time believed to extend to the Pacific coast, and to have been collected there by Menzies; but the species found by him, although closely related to our fern, is now regarded as a distinct form, and is called $A$. auriculatum.

Our plant has its home in the states east of the Mississippi, or as Mr. Redfield expresses it, in the Appalachian geographical group. It is found in almost all the states of this group, from the Great Lakes to the Gulf of Mexico; and should occasion arise at any time for the adoption of a fern as a national emblem, none could probably be found to meet the requirements better than this.

Many ferns have their fruit-dots on fronds nearly or quite like those which are barren, while others have them on fronds differing entirely in character from the sterile fronds. It is interesting to note that the Christmas Shield-Fern is intermediate between these two classes The fruiting fronds of our species are merely a little more incised or cut-toothed on the edges, and even in these fronds, only the upper portion, on which the fruit appears, has this character, while the lower portion, which bears no sori, is like the barren ones. Sometimes all the fronds, barren as well as fertile, are incised, which condition was formerly supposed to denote a distinct species, named $A$. Schrucinitzii, but this distinction has now been abandoned.

In an average-sized pinna there is but a single row of sori on each side of the midrib, but in the stronger ones there is generally a double row, and at the season of maturity the whole back is covered with the sporangia.

Explanation of the Plate. - I. A plant rather below the medium size. - 2. Pinna from a male frond, showing the disposition of the veins. - 3. Pinna from the fertile portion of a frond, just previous to the bursting of the sporangia through the membrane of the indusium, and exhibiting its more deeply cut margin. 


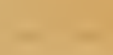





\title{
POLYGONUM ARIFOLIUM.
}

\author{
IALBERD-LEAVED TEAR-THUMB.
}

NATURAL, ORDER, IOLFGON.ACE.A.

Polygoxum Arifolium, Linnxus. - Stem grooved-angled; leaves halberd-shaped, taperpointed, long-petioled; flowers somewhat racemed (few); peduncles glandular-bristly; calyx often four-parted; stamens six; styles two, very short; achenium lenticular (large). (Gray's Munut of the Botany of the Aorthern ('Mrled Stutes. See also Chapman's Flora of the Southerne Unitad States, and Wood's Chass-Bools of Botany.)

HE natural order to which our present species belongs comprises only few genera, but its representatives are nevertheless to be found over the greater part of the world. The Dock, the Sorrel, the Buckwheat, and the Rhubarb are among its more northern species, while another member of the order, the Seaside Grape, well known for its beautiful berries, is at home in Florida and still farther towards the tropics, beyond the southern boundaries of our territory. The order is named Polygonacea, from the genus Polygonum, to which the subject of this chapter belongs. Polygonum is the largest genus in the order, numbering more than two hundred species; but these latter are so variable and so difficult to define, that much difference of opinion cxists among botanists as to their identification. In consequence of this difference of opinion, many attempts have been made to divide the species into several genera, but as these attempts were not universally recognized as legitimate, their chief result has been to originate quite a number of synonyms, such as Persicaria, Bistorta, Avicularia, Towara, and others, most of which are now used as convenient subsectional names. Some of our best botanists, however, are still 
in favor of dividing the genus. Thus Mr. Sereno Watson, in a paper published in the "American Naturalist," for IS73, says that it ought to be "restricted to the two sections Avicularia and Tcphis." If this view should prevail, our present plant would cease to be a Polygonum, and would have to be called Tiniaria arifolia, since it belongs to the subsection Tiniaria. A cliscussion of the technical points involved in these questions is, however, entirely beyond the scope of these pages, and we must therefore rest satisfied with having called the reader's attention to the facts noted.

The name Polygonum is quite old, and is identical with the Polygonum of Dioscorides. Pliny also mentions the plant, with the remark that it is used to stanch blood. The species which were known at the time of these writers, and which are still included in the genus, are noted for their knotted and bent stems, and this peculiarity suggested the name, which signifies "many-kneed." Our plant scarcely does justice to the name, however; for, although it has a somewhat zigzag or bent habit of growth, it is free from the knotty knees of some of the related species. The specific designation, arifolizm, refers to the leaves, which resemble those of many of the species belonging to the Arum Family.

Polygonum arifolium always impressed us as having a delicate, graceful beauty, well worthy of adniration, and probably most persons who examine the accompanying plate will agree with us. Botanists, however, generally regard it as nothing but a weed. Dr. Darlington speaks of it as follows: "This and P. sagittatum usually grow in company, clambering over other plants, and forming entangled bushes. Both are worthless, unwelcome wocds, in meadows, especially among second crop hay." So sharp a criticism from so amiable a man as Dr. Darlington is rather surprising; but the allusion to the "second crop hay" makes it evident that, for the moment, he had forgotten he was writing on general botany, and had fallen into a train of ideas which would have been quite natural in his "Agricultural Bot- 
any"; for the husbandman, for very good reasons, often calls "a weed" what others delight in as a beautiful flower. It is all the more singular to find, on the other hand, that Dr. W. C. P. Barton, who is apt to be more tart than Dr. Darlington, has a good word for our plant. This author, in his "Flora of North America," after explaining that the plant is called "TearThumb," because its sharp prickles are apt to tear the fingers of those who handle it, adds that "in favorable situations it is not clestitute of beauty." This is, indeed, but negative praise, but it is better than downright condemnation. The specimen which Dr. Barton selected for the illustration in his work is of the palcr, denser-headed kind. We have purposely chosen a darker-colored and more slender-flowered lind, so as to show the beauty which the plant often possesses, and at the same time to enable the reader, by comparison with Dr. Barton's plate, to get some idca of the great range of its variation.

Polysonum arifolium not only grows wild in meadows, as noted by Dr. Darlington, but it is even more at home in grounds so wet as to be almost ponds at certain seasons of the year. The seeds, in fact, will germinate in water, under favorable circumstances. When clambering over an isolated bush, our plant forms a truly beautiful object; and in some swampy spot in a garden, or with the aid of an artificial arrangement suited to its habits, it might, with a little care, be made a very attractive feature, - provided that its "thumb-tearing" qualities are no objection.

The thorny prickles with which the plant is armed have long been an object of study to those who love to fathom the secrets of nature. Dr. Erasmus Darwin, who lived eighty years ago, and was, like the modern Darwin, an evolutionist, wrote a curious book called "Phytologia," in which he advanced the idea that all plants were originally thornless, and that the thorns were only formed as a sort of protection against injury, after insects and other animals had appeared on the earth. Linnæus also had regarded these appendages as the "armor of plants," but he had not gone 
so far as to believe that they were later acquisitions, produced according to the law of natural selection. Nor was Dr. Darwin's theory generally accepted; and Anthony Todd Thompson, a famous lecturer, who flourished about twenty years after the appearance of "Phytologia," in controverting the theory in question, went so far as to say that "most of the notions which our reasonings on final causes lead to, are neither philosophical nor accordant with correct observation, and we must confess our ignorance of the utility of this description of armature in the vegetable economy." It is curious to note in this connection that Dr. Thompson, who, as may be learned from the extract just given, considered himself a champion of exact science and an enemy to fanciful "speculations," was himself looked upon as a mere "speculator" by those who followed Dr. Darwin's progressive views. The modern student, however, although he may, with Dr. Thompson, confess his ignorance of the precise meaning of such armatures as those borne by our Tcar-Thumb, does not consider the solution of the question as absolutely impossible, and therefore looks upon the thorns as legitimate subjects of philosophic study. Some later botanists have regarded them as aids to climbing rather than as a mere protecting coat of mail, and this purpose they certainly serve excellently well, whatever may have been the object for which they were originally intended.

In its geographical range within the United States the Polygonum arifolium prescnts some interesting features. It is found in Maine and southward through the Seaboard States to South Carolina, but in its progress westward it avoids the South, and shows a northern tendency. It grows in Ohio, and thence through Michigan and Wisconsin to Minnesota. Prof. Aughey also reports it from Nebraska, but it has not yet been found in any part of Iowa, as far as we know. Its line of distribution, therefore, secms to form two narrow belts, one running due west, the other southwest.

It is in bloom from July to September. 

Vil II

Plate 4 .

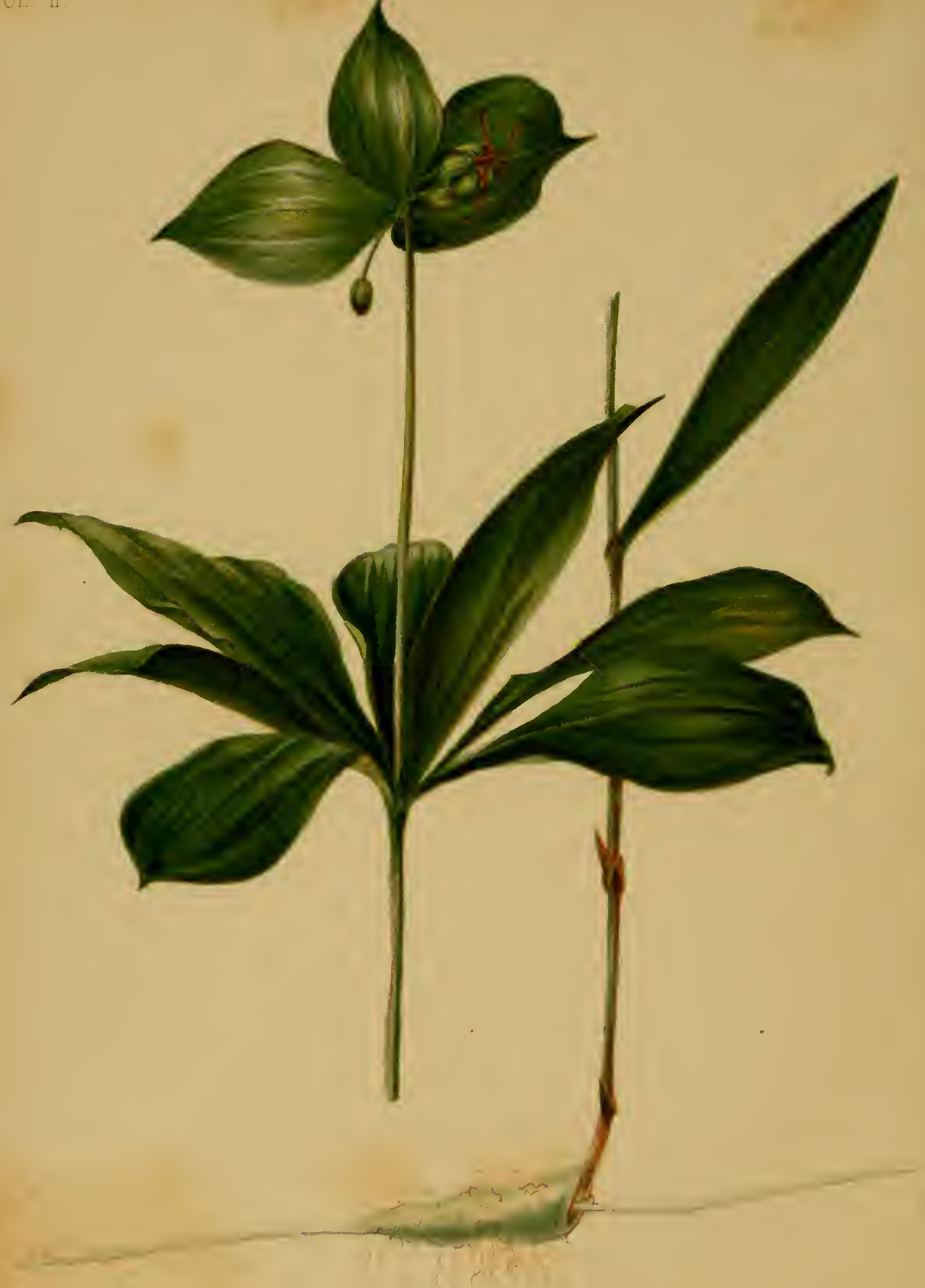




\title{
MEDEOLA VIRGINICA.
}

\author{
INDIAN CUCUMBER.
}

NATURAL ORDER, TRLLLIACEE.

Medeola Virginica, Gronovius. - Sepals and petals nearly alike, lanccoblong, revolute, deciduous; anthers linear-oblong, incumbent; styles long, lincar, recurved, diverging, stigmatic on the upper side, dark purple, deciduous; berry globose, dark purple, threccelled, few-seeded; rhizome oblong, fleshy, white ; stem simple, slender, loosely floccosepubescent, with a verticil of five to nine leaves ncar the middle, and another of three at the summit ; flowers pale greenish yellow, sub-umbellate, nodding; pedicels erect in fruit. (Darlington's Flora Cestrica. See also Woud's Class-Book of Rolany, Gray's Minuarl of the Botany of the Northern United States, and Chapman's Flora of the Southern Cruted States.)

HE commentators tell us that the Mcdcola was so named supposed to possess great medicinal virtues; but from all we can learn, it does not appear that any one ever said or thought it had any of these virtues. The name was first given to our species by Gronovius, and is generally dated from its adoption in Linnæus' "Genera Plantarum," published in 1737 . It is very likely that it was suggested, as was Andromeda to Linnæus. by a similarity between some phase in the life of the plant and some one of the incidents narrated by Ovid in his story of Medea. Of the latter it is said that she was a wicked sorceress; but in truth, she had much to provoke her. The daughter of a ling, and the victim of a tender passion for the enemy of her father and her countrymen, it was but natural that she should make use of her magical powers for the purpose of aiding the man she loved; nor is it difficult to understand why her fiery temper should have been roused, when, after she had helped the 
man she loved to triumph over her friends, and had fled from her home and her fatherland for his sake, -

"She saw new decked the nuptial bed, And proud Creusa to the temple led, Saw her, in Jason's mercenary arms, Deride her virtues and insult her charms."

There is nothing in all this, however, to remind us of our Mcdcola. But Ovid, in the course of his narrative, tells us, in the eighth book of his "Metamorphoses," that, after Medea had cletermined in her mind to follow the fortunes of Jason, "she felt a sense of virtue and of shame, and the duties she owed to her father presented themselves to her, and Cupid was about to retire vanquished. Straight she repaired to the venerable altar of Perseian Hecate, sheltered in a shady grove and the remote recesses of a wood. And now she was resolved; and the ardor of her passion, by being checked, was considerably abated, when she sees the son of Æson, and the extinguished flame was kindled anew. Her cheeks were covered with blushes, and her whole face was in a glow." It seems to us that Gronovius may have had this passage in his mind when he named our plant Niclcola. In the retirement of the "shady groves and the remote recesses of the woods" in which it grows, it is seen in June in the verdancy of youthful innocence, as shown on our plate; but in September, its leaves, like Medea's cheeks, are "covered with blushes, and her face is in a glow." Nothing is more strikingly beautiful than the crimson and green of our specics at this season of the year, and to a poetically inclined person, thoroughly read in the classics, it might well recall Neclea in the situation delineated by Ovid.

Although the Medeola Virginica is by no means showy, it is, nevertheless, quite interesting to the collector and the student. It looks like a lily at first sight; but we remember that the lilies have only a single pistil, although this is often three-lobed at the apex, while the Mrdcola has three distinct styles, which 
are finally recurved. Our species is, therefore, classed in the order Trilliacca, although in reality it differs but very slightly from the lily family, or Liliacea, and might in truth be said to occupy a place between the two in the chain of relationship. Some botanists indeed, as Dr. Gray, for instance, class the genus Mcdcola with the Liliacia, while others, among whom is Dr. Chapman, give it a place in the order of Smilacca.

The structure of the flower is worthy of attention. There are six stamens, but they evidently form two whorls of three each, although they are all apparently of the same age and strength. But observation will show that the anthers of one set mature their pollen one day before those of the other set, which makes it evident that all the parts of the flower are in threes. The six-parted perianth really consists of three sepals and three petals. There is an inferior set of three stamens and a superior one of the same number, and there are three pistils belonging to as many carpels.

The manner of fertilization in our species is particularly interesting. The anthers of the outer series, as before noted, burst their cells first, and before the pistils of the flower are ready to receive the pollen. If there were insects to carry the pollen to other flowers, there would be a good chance for cross-fertilization. The writer, however, has failed to notice any insects at work on the flowers in the wood where his observations were made, nor has he been able to find any pollen on the stigmas until they receive it from the anthers in their own flowers. The way in which this pollen is received is as follows. As already noted, the anthers of the outer series of stamens burst first. Soon afterwards, the pistils curve downwards, so that the stigmas are between the unexpanded anthers of the interior series. When the pollen of these anthers has matured, the pistils are, of course, in the best possible position to receive it, and self-fertilization seems extremely easy. It remains to be seen, however, whether this is the rule in all cases, to the total exclu. sion of crossfertilization, and the subject is, therefore, well 
worthy of close observation and investigation. Some pollen from the lower series of anthers may possibly be carried to neighboring flowers by the wind.

- The root, as shown on our plate, has a præmorse or bitten-off appearance, and when the growing time comes, one bud makes the new plant, while from another bud at the base proceeds a thread-like runner, which, toward the end of the season, gradually thickens and forms the tuber from which next year's plant is to grow.

According to Pursh, the root is eaten by the Indians, and as it is said to taste like the cucumber, the whole plant has received the common name of "Indian Cucumber." This is the only indication we find of its ever having been really useful to man.

The Icdcola Virginica is by no means confined to Virginia, as its specific name would seem to indicate, but is found in damp, shaded woods in most of the states of the Union east of the Mississippi River. Its flowering time is in June and July. 



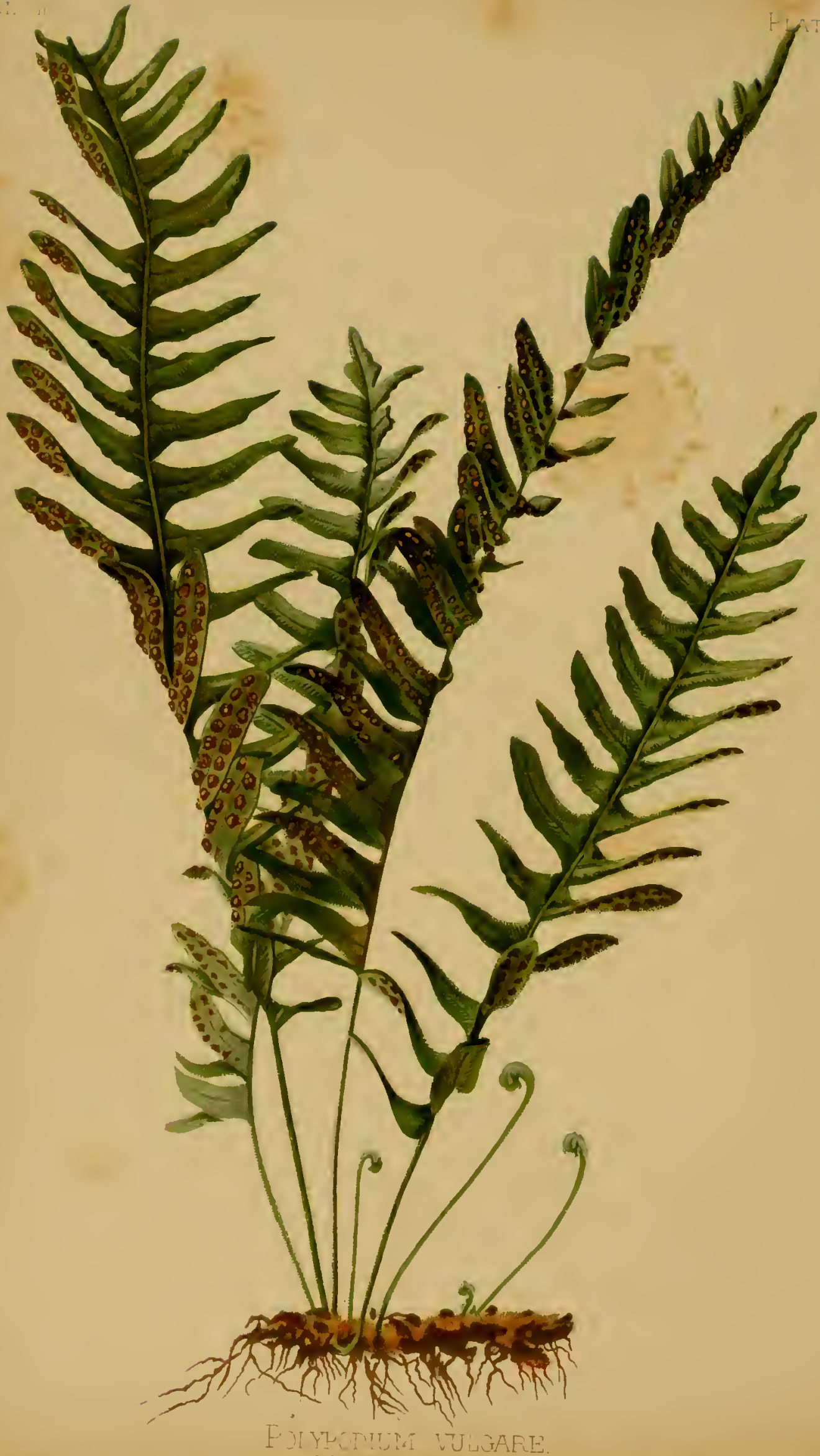




\title{
POLYPODIUM VULGARE.
}

\author{
COMMON POLYPODY.
}

\author{
NATUR.II, ORUER, FILICES. (POA.YPOD1ACEA.)
}

\begin{abstract}
Polypodium velgake, Linnxus, - Frond deeply pinnatifid, smooth; segments linear-oblong, obtuse, crenulate, the ulpper ones gradually smaller; sori large, distinct ; roots clothed with membranous scales; fronds six to twelve inches, divided into alternate segments nearly to the midvein; stije naked and smooth; segments parallel, a little curved, alonut one quarter inch wide; fruit in large, golden dots in a clouble row, at length brownish. (Wrood's Chiss-Book of Botuny. See also Gray's Mronut of the Botuny of the Northern Linited Stat's, and Chapman's Florit of the Southern Cinitut States.)
\end{abstract}

HE meaning of the word Polypodizm, in its botanical application, is obscure, like that of so many other names of plants which were in use by the aneients, and were adopted into the language of modern botany. Mr. John Smith, in his "Historia Filicum," published in London in $1 S 75$, says that Polypodium is "from polys, many, poys, foot: polypus; the rhizome, when destitute of the fronds, having the appearance of some kind of sea-polypus"; and some similar explanation is given by most authors. It seems to us, however, that the name admits of still another cxplanation, which is equally as good, if not better. One of the genera of Filices, formerly classed with Polypodium, is called Scolopondrium, from scolopendra, the centipede, on account of the resemblanee in its finely pinnate or divided frond to the legs of the insect just named. It is quite probable the name Polypodium, as applied to these ferns, had a similar origin, and was suggested by the many-footed appearance of the frond.

The Polypodium vulgare was well known to the ancients, and, as Sibthorp tells us, is still called by its old name by the Greeks 
of our own day. It is described as Polypodizm by Dioscorides, a Greek medical writer of the first century of our era, and from that period down to the present has been connected with the healing art, although its medical history is rather checkered. Our species used to be quite famous as a remedy for dropsy and jaundice; but it has also been employed as a purgative, and was at one time believed to have the power of driving away melancholy, while together with liquorice it was used as a pectoral in coughs and asthmas. In most of these complaints the roots were used, which had to be gathered in autumn. Dr. Titford furthermore tells us that the ashes of this species were used instead of soap, and that an oil was distilled from them with lime, "which," as he says, "is used with the oil of stone to varnish porcelain." This application of the "oil" does not seem clear, however, as porcelain needs no varnish, since it receives a glaze in the fire. From the same author we also learn, that, after it had fallen into a bad repute for some time, it became quite famous again as a remedy for tæenia, or the tape-worm. Madame Monfer (the discoverer of the remedy) received a very great sum from the king of France, to whom she disclosed the secret of her discovery. Her story was that she "reduced the dried autumn roots to fine powder, and then dissolved two or three drachms in four or six ounces of water distilled from ferns."

It is more than probable, however, that the medical virtues of the Polypody are of little moment. Dr. Porcher, who was medical director of the Southern Confederacy during the war, when there existed an absolute necessity in the South of turning all its available medical resources to the best possible account, speaks of its virtues as a mere matter of report.

There was a time when our Common Polypody, as it is found in America, was regarded as distinct from the Old World forms, and was known as Polypodium Virginianum. Prof. Kunzé, of Leipsic, a modern author and good authority on ferns, indeed, contends that the American form is a distinct species. 
"Polypodium vulgare, var. Amcricanum, Hook.," says he, "is the Polypodium Virginianum of Linnaus, and differs from the European form by a narrower and more elongated frond, narrower lobes separated by a wider sinus, the lowest being longer, or at least not shorter than the following ones, and the sori being always nearer the margin than in the European plant. I have not met with any American specimens entirely agreeing with those of the Old World." It is very difficult to decide a question like this. But on the whole it may be said that the slight differences noted by Prof. Kunzé can hardly be considered of sufficient value as points of distinction between two species of a class of plants, so variable as the ferns, as every cultivator knows. In the light of the increased knowledge of this variability the two forms are therefore looked upon as simple varieties by the great majority of the botanical authors of the present day.

The Polypodium vulgare has not

"The oratory

That speaks in perfumed silence,"

which so many of the sweet-scented flowering plants have; but yet its language to all who love to commune with Nature in the solitude of her quict woods is eloquent enough. It has something to tell us even in winter, when the pretty flowers, robbed of their perfume, are not only silent, but dead, or at least soundly asleep. Our species is evergreen, and indeed its fronds are more interesting in winter than in the summer season. The beautiful fruit-dots, so regularly placed on the leaflets, form in July, but do not put on their bronzy hue before fall, and are most brilliant in winter. These clusters of sporangia remain on the leaflets until the frond dries up and blows away. One might be tempted to ask why the spores, if they are intended to insure the increase of the species, should remain so long inactive? As rapid a dispersion as possible would seem to be much more advantageous in view of the end to be gained; and yet we see 
that the plant has all the benefit to be reaped from an increase by spores. Few other plants have made their way more easily over the world; and if we admit its varying forms to be really the same species, we shall find the Common Polypody in most parts of Europe, in Algiers, Madeira, and the Canary Islands, in Japan and China, and in other parts of Northern Asia. On our own continent it is found in Greenland, across the whole of Canada, and throughout the greater part of the United States as far west as the Rocky Mountains, and even beyond, in Utah. In the South, according to Dr. Chapman, in the second edition of his "Flora," it finds its limit in the mountains of North Carolina; but it also occurs in Mexico, and in the IVest India Islands. In California, according to Mr. Watson, it has not yet been found in its true or typical form. Of special localities, Grayson County, Kentucky, is mentioned by Mr. C. C. Haskins, and Lexington, in the same state, by Mr. J. IVilliamson. In the dells of the Wisconsin it is very common, according to $\mathrm{Mr}$. Copeland. This wide clistribution of our species shows that the methods adopted for its propagation by Nature have given very satisfactory results. The plant loves rocks and trees, and is found more frequently on the latter, and on old stumps and $\operatorname{logs}$, as we go northward.

Our drawing was made from a specimen gathered from a tree in Massachusetts. In rocky situations in Pennsylvania the fronds are shorter, and their upper surfaces are of a decper green. Our artist has made a very pretty picture of the plant, while at the same time he has kept in view the presentation of every important botanical character.

This species is very generally known as the Common Polypody, and in our large cities, to which the fronds are brought in large quantities in winter, for use in cut-flower work, it is also frequently called "Evergreen Fern," although there are several other ferns to which this name is also given. 



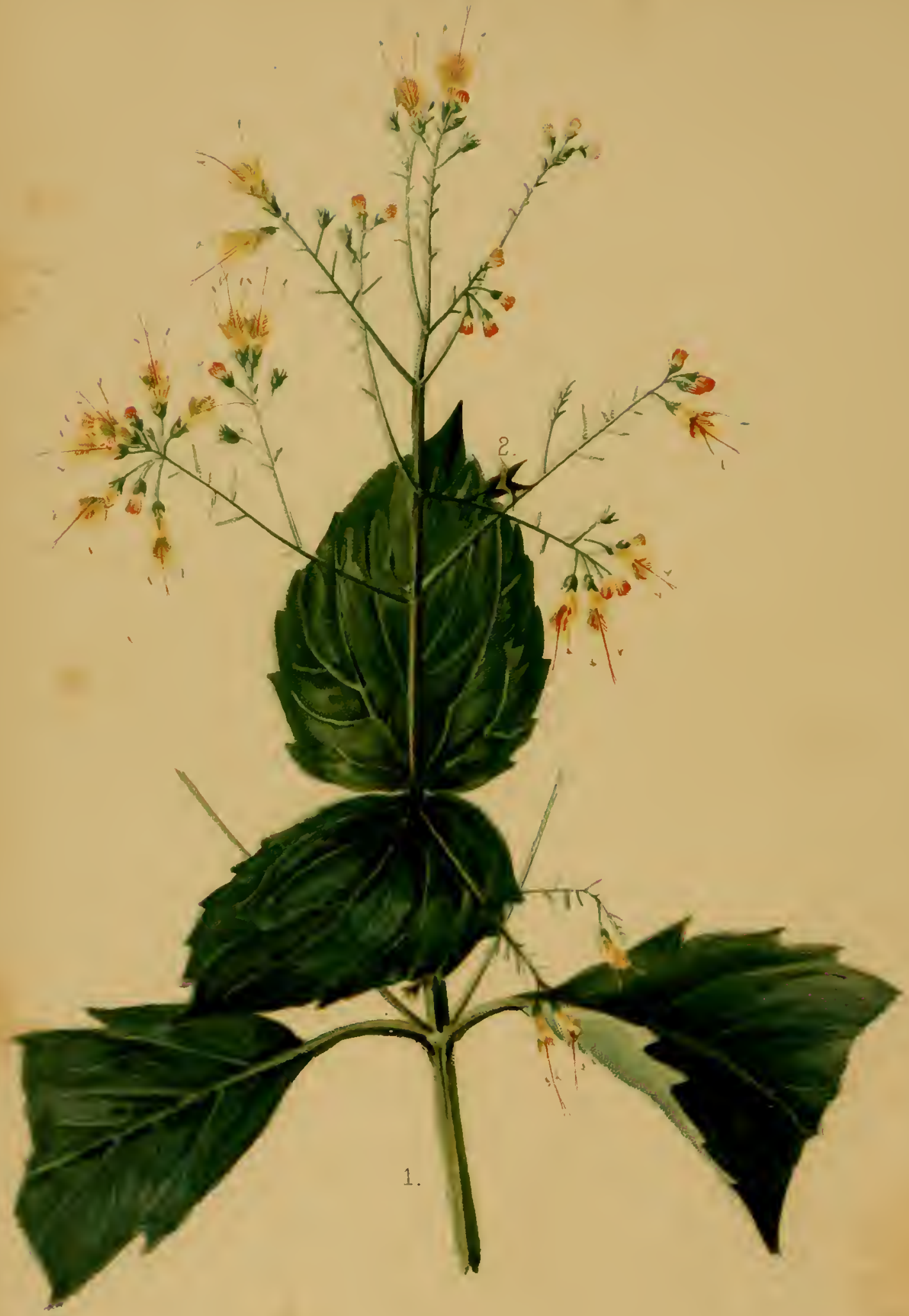




\title{
COLLINSONIA CANADENSIS.
}

\author{
COLLINSON'S FLOIVER.
}

\author{
NATURAL ORDER, LABIATE. (LAMIACE.E OF LINDLEY.)
}

Collinsonia Canadensis, Linnxus. - Leaves ovate, acuminate, coarsely serrate, petiolate, thin and smoothish; racemes elongated, many-flowered; flowers peclicellate, axillary, and opposite : stem two to three feet high, somewhat branched, smoothish below, pubescent above; leaves four or five to eight or ten inches long, and three to five inches wide, resinous dotted beneath; petioles one to three or four inches long, the leaves at the base of the panicle smaller and subsessile; fowers loosely racemose; pedicels one thircl to one inch long, with minute, lance-ovate, acuminate bracts at the base; cotolla greenish-yellow, the lower lip fringed. (Darlington's Flora Cistrica. Sce also Gray's Manual of the Botany of the Northern United Shte's, Chapman's Flort of the Southern United Stutes, and Wood's Class.Book of Botany.)

HE genus Collinsonia is truly American, and commemo19.0. rates the name of one of the earliest friends of American botany, Peter Collinson, of London. Collinson, who died in 1768 , in his seventy-fifth year, was a wealthy Quaker and a dealer in woollen goods. He had a fine garden, and introduced a large number of rare plants, especially from North America. John Bartram, our early botanist, was in active correspondence with him, and seems to have sent him, among his earliest collections, seeds of the plant named at the head of this page, for in a letter from Collinson to Bartram, dated Scpt. 2, 1739 , and published in Darlington's "Mcmorials," the English amateur botanist writes as follows: "At the bottom of the box is a specimen of what our botanists have dubbed Collinsonia, but I think it should rather be Bartramia, for I had it in the very first seeds thee sent me. Miller is mistaken in making it come from Maryland. Pray, fail not next year to send me some more seed of it." Collinson very likely took care to correct Miller's mis- 
take through the medium of some of the English serials, for we find Green, a subsequent writer, much more particular in his statement of the location of the species than was customary at that time in the case of American plants. The last-named author says that the Collinsonia Canadcnsis "is a native of North America, in Pennsylvania, in a rich soil about 43.15 north latitude. Mr. Barton was the first who discovered and sent it to Europe." But, in spite of Green's attempt at accuracy, his statement is disfigured by two sad blunders, which, if they should occur in our "Native Flowers and Ferns of the UnitedStates," would be considered unpardonable in these fortunately more critical and exact times. We have seen already that Bartram, and not Barton, was the man who sent the first seed of our plant to England, and a glance at the map will show that Pennsylvania is a good piece to the south of latitude 43.15 north. It is quite likely, therefore, that Green meant to say 40.15. Linnæus, who visited Collinson in 1736 , and in 1737 published an account of the plants he had obtained from his English friend, called our species Collinsonia Canadcnsis.

Our specics was made very prominent in botanical literature by the curious behavior of its pistils, which was first noticed by Dr. Darwin, the well-known author of the poem called "The Botanic Garden," published at the beginning of the present century. In a foot-note in this work, Dr. Darwin writes as follows: "I have latcly discovered a very curious circumstance in this flower: the two males (stamens) stand widely diverging from each other, and the female bends herself into contact first with one of them, and after some time leaves this, and applies herself to the other. It is probable one of the anthers may be mature before the other." In his "Loves of the Plants," the same author personifies the stamens and the pistil, and thus sings of their tender passions:-

"Two brother swains, of Collins' gentle name, 'The same their features and their forms the same, With rivai love for fair Collinia sigh, 
Knit the dark brow and roll the unsteady eye. With sweet concern the pitying beauty mourns, And soothes with smile the jealous pair by turns."

Nuttall, however, takes quite a different view of the action of these organs in our plant. According to him, the fair Collinia - the pistil - soothes neither of the jealous pair, but remains entirely unmoved by their passion. "In this genus," he says, "the stamens are observed alternately to approach the style," which, of course, is quite the contrary of Dr. Darwin's observation.

It is worth noting in this connection that the ancestor of the chief exponent of the prevailing belief that self-fertilization is shunned by the higher-class plants, the present illustrious Darwin, should have imagined this supposed motion of the pistil to be an especial contrivance to insure self-fertilization. The writer of this has never been able to see this action of either the stamens or the pistil, nor does any modern author note it. The matured specimen selected for our illustration certainly shows that the flowers do not seed well, even if they should be self-fertilizers, as suggested by the observations of Dr. Darwin and Nuttall. Of the many flowers that have opened, only one seems likely to perfect its seed, as shown by the seed-vessel marked with the Fig. 2 on our plate. Bees visit the flowers freely sometimes; but although the writer of this has watched their actions closely, he has rarely seen them touch the stigmatic surface. Perhaps if they did, and foreign pollen were applied, the result might be different, and it would be a good argument favoring cross-fertilization.

Medicinally our species is famous. The Indians employed it in curing sores and wounds, and Rafinesque says that among the mountaineers of Virginia, Kentucky, Tennessee, and the Carolinas, "it is used inwardly and outwardly in many disorders, - outwardly as a poultice, and inwardly as tea for headaches, colics, cramps, dropsy, indigestion, ctc." Linnæus, in Schreber's edition of "Materia Medica," admits the root as a remedy in 
colics. In very many cases, the reputations which plants used to have for good medical properties in the past, have been found to be exaggerated, if not wholly fictitious ; but Dr. Peyre Porcher, in his "Resources of the Southern Fields and Forests," after weighing the evidence, comes to the conclusion that "this plant certainly merits further notice." The same authority also tells us that the bruised leaves are used in the Southern States for the "eruptions caused by the emanations from the poison sumachs."

The common names given to the Collinsonia Canadensis are so numerous that it is difficult to choose among them, and to recommend one of them for general acceptation. There are Richweed, Heal-all, Horseweed, Stoneroot, Knotweed, Knotroot, - the three last from the knotty, stonelike roots of the plant, - Horsebalm, and perhaps others. As the genus is to commemorate Peter Collinson, one of the patrons of American botany, we venture to suggest the name of "Collinson's Flower."

Our species is found in the rich soil of shady woods in most of the Atlantic States, where it is in flower during July and August. The specimen from which our draving was made came from Pennsylvania. No doubt some of our botanical friends will feel quite sure that they could have found a much prettier specimen for illustration than the one we have selected. A younger plant, gathered while the branches of the panicle were less scattered, would certainly have made a much more effective picture; but instructiveness must take precedence even of beauty, and a maturer specimen, such as we have chosen, is much better fitted than a younger one to illustrate the points to which we desired to call attention. The figure on our plate is of the exact size of an almost overblown branchlet of the panicle. Early flowers, as also the stem leaves, are, of course, much larger.

Explanation of the Plate. - I. A panicle, almost overblown. - z. A maturing seedvessel. 



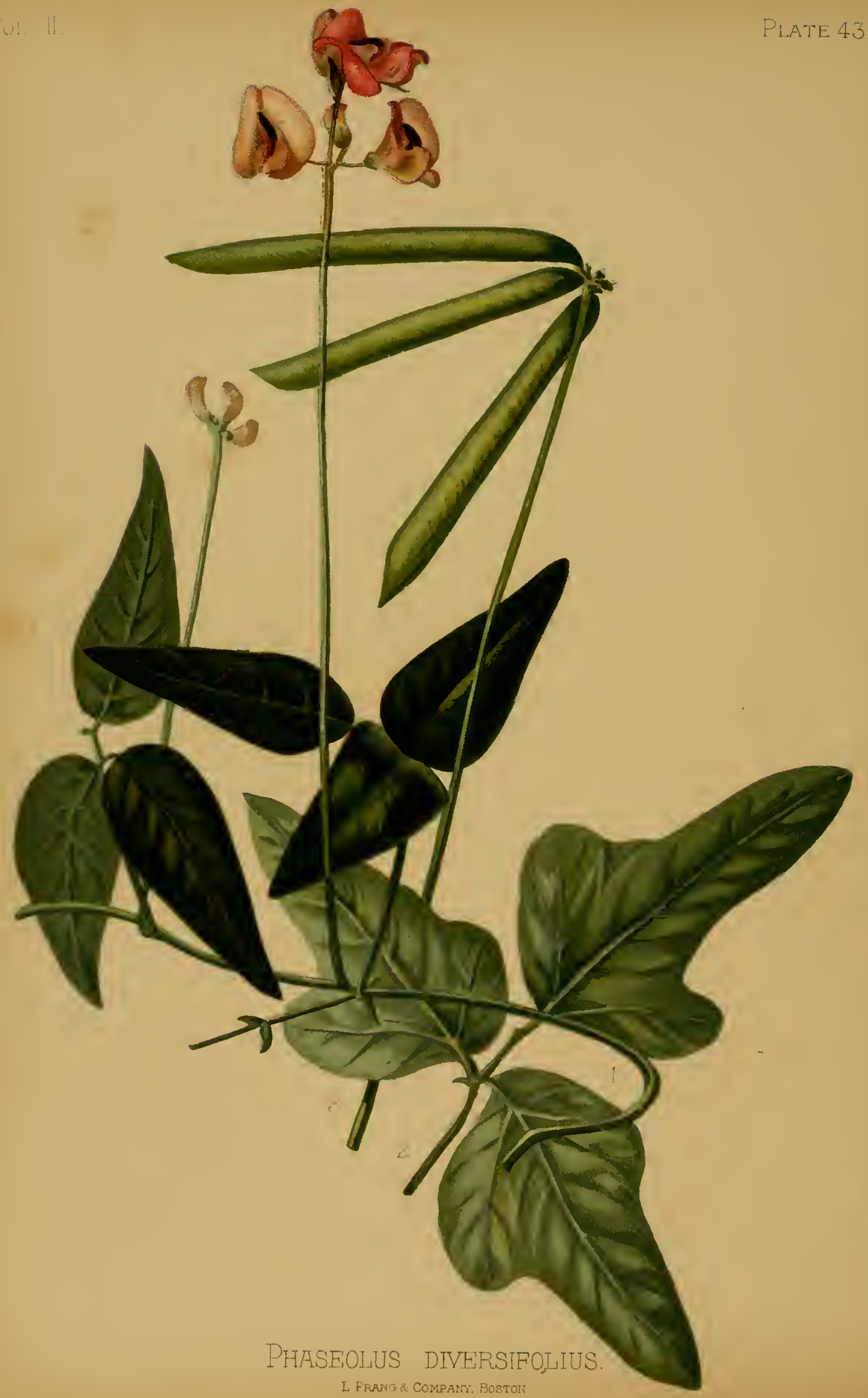




\title{
PHASEOLUS DIVERSIFOLIUS.
}

\author{
DIVERSE-LEAVED KIDNEY-BEAN.
}

NATURAL ORDER, FABACEA. (LEGUMINOS.E. PAPLLIONACE.)

Phaseolus diverstrolut, Persoon. - Stems prostrate, diffuse, scabrous, with recurved hairs; leaflets angular, two to three-lobed or entire; peduncle longer than the leaf, fow-flowered; lower tooth of the calyx longer than the tube; legume pubescent, broadly-linear, cylindric; leaflets one to two inches long, three quartcrs as wicle, with scattered hairs beneath, often variously and very obtusely lobed; peduncles two to eight-flowered, three to six inches Jong; corolla purplish; legume becomes black when ripe, five to seren seeded. (Wood's Class-Book of Botuny. See also Gray's Mtenul of the Botany of the Northern Unitud Sutus, and Chapman's Flord of the Southern C'nitut Stutes.)

\section{露}

$\mathrm{HE}$ order to which the Kidney-Bean family belongs is while others call it Legzminosa, from the legumes borne by the plants classed in it, and others Papilionacece, from the butterflyshaped flowers. The history of the family reaches far back into antiquity. The Common Kidney-Bean was cultivated in prehistoric times, and it is frequently mentioned by Greck and Latin authors. Julius Cæesar says that it was grown by the "Turcicos," who had evidently received it from their Scythian ancestors; Columella, an author on husbandry, of the time of Claudius Cæsar, notes it as Phascolus among the cultivated legumes of his age, and Pliny also writes of it under this name; while Dioscorides, a Greek physician of the first century of our era refers to it as Phasiolon. Phascolus signifies a little boat, and it is claimed that these plants were so called from the shape of their pods. But the beans themselves may just as well have given rise to the name, as many of them resemble a boat quite as much as a kidney. It is not always an easy matter to trace 
the derivation of these ancient names to an undoubted source, and this is true also in the case of the Kidney-Bean. Many authors therefore prefer to attempt no explanation, and rest contented with informing their readers, as Dr. Gray does, that Phaseolus is "the ancient Latin name."

Theophrastus, a Greek writer of the fourth century B. C., also mentions our plant, but calls it Dolichon, and from this word the name of the genus Dolichos, which likewise belongs to the order Fabacea, has been derived. Botanists, however, are not quite agreed as to the species which should be classed with this latter genus, or with Phascolus; and several species, therefore, which are placed in Dolichos by some authors, are relegated to $P$ hascolus by others, although the two genera can be distinguished by various characteristics, one of these being that in Phascolus the keel of the flower, with its stamens, is curiously twisted, while in Dolichos it is straight. Our own plant was held to belong to Dolichos by Nuttall and some of his contemporaries. To others, however, it seems to be distinct from both the genera named, and it was therefore made into a new genus, and was called Strophostyles angulosus by Elliott, a botanist of North Carolina, who wrote in $1 S 16$ and succeeding years. Ortega, a Spanish botanist of the latter part of the last century, describes it as Phascolus angulosus, which name is still used in some European works, and Michaux calls it $P$. trilobus. There are still a number of other synonyms, but our readers are not likely to meet with them, as $P$. divorsifolizes is the name generally used by American botanists.

The specific appellation, diversifolius, refers to the diverse forms of leaves found on this plant, a peculiarity which is well illustrated by the leaves shown on our plate. This curious variability is prominently alluded to in all descriptions, and the writer of this has had a good opportunity of noting it by observing a number of plants raised from seed kindly sent to him by Mrs. Mary Treat, of Vineland, New Jersey. Some of these plants had almost every leaf deeply lobed, others had some 
leaves robed and some entire, and others again had all of them entire. The flowering specimen on our plate was drawn from one of these entire-leaved plants, while the lobed leaf in the illustration was taken from another plant in which nearly all the leaves differed.

It is exceedingly interesting and important to observe such variations, as they have much influence in establishing the doctrine of evolution, since they tend to show how one form may grow out of another. Thus the leaflets represented in Fig. 2 on our plate are not only lobed, but a strong midrib has also been formed in each lobe. These midribs have their scparate lateral veins, and we can easily see that, with a little more effort, there would be a complete subdivision, making a leaf of nine leaflets instead of three, as now. Again, we may learn, from the lessons afforded by our plant, how one species may eventually branch out into several distinct species. As matters stand at present, we cannot base different species on the different shapes of the leaves, because these several shapes are variable, and may occur now on this, now on that plant, or perhaps even all together on one and the same plant. But if it should ever happen that the descendants of certain plants, under a variety of circumstances, and through a long series of years, have only entire leaves, while the descendants of others have only lobed leaves, without either of them showing any sign of a desire to return to the variable condition, we should then be justified in looking upon the shape of the leaves as a fixed character, and in building a species upon this character, although we knew that all these plants originally came from one stock. In further illustration of what we have said, we may point to $P$. hclvolus, a species allied to $P$. divcrsifolius, and probably of the same origin. One of the chicf characters at present relicd on to distinguish these two species is the length of the flower-stalks, which latter in $P$. divcrsifolizs are always much shorter in proportion to the leaves than in $P$. hicluolus.

Our plant trails over the ground in its wild state, but under 
cultivation it is easily persuaded to twine up on stakes, and thus grown it makes a very ornamental object in the garden. Quite a peculiar feature is the change of color which the flowers undergo. When they open they are of a pretty, rosy purple, as in the uppermost flower on our plate; but soon they commence to change, and by the second day or so they are of a pale pinkish-yellowish white, like the two lower flowers in our drawing.

The curious twist in the keel of the species belonging to Phascolus, which we have alluded to before, is very striking, and has by some botanists been considered an arrangement favoring cross-fertilization. On the least pressure on the corolla the pistil protrudes; and if this pressure is exercised by an insect having pollen on its body, some of the pollen is deposited on the pistil.

$P$. diversifolizs is remarkable for its northern range, being the only species of its genus which is found in Maine, while most of its allics are tropical. It has a very wide range of territory, as it occurs more or less abundantly from Maine southward in all the Seaboard States to Florida. Across the Mississippi it is found in Texas, and through Arkansas and Kansas to Nebraska, which seems to be its northwestern boundary; and from there it sweeps eastward through Iowa, and along the lake region, until it again reaches the sea. Many plants are found in widely distant parts of our country, but few have so regular a distribution as our present specics.

The Phascolus diversifolius seems to have received no common name, but its beauty and the many other points of interest which it offers will no doubt bring it into popular notice some day, when it may receive a familiar title from its admirers. In its wild state it grows in sandy fields and banks, or on sandy lake-shores, and flowers from June to October, according to the locality.

Explinitron of the Plate. - r. Part of a flowering branch. - $=$. Leaf from another branch, showing the leaflets and venation from the under surface. -3 . Stem with unripe pods. 



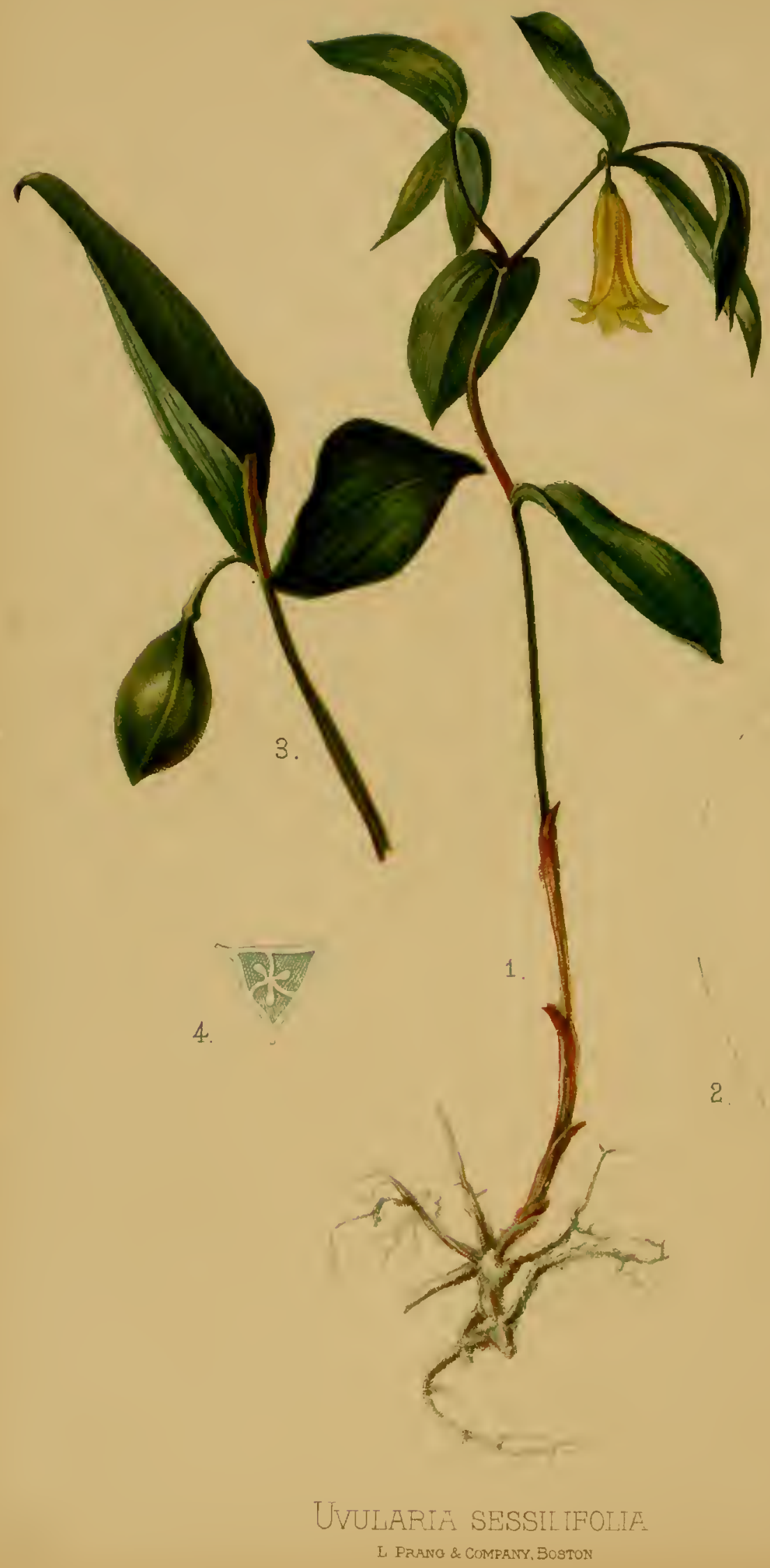




\title{
UVULARIA SESSILIFOLIA.
}

\author{
SESSILE-LEAVED BELL-IVORT.
}

NATURAL ORDER, LILIACE.E.

UVULARIA SESSILIFOLIA, Linneus. - Leaves oral-lanccolatc, sessilc ; perianth smooth within; capsule acute at cacli end; stem nine to twelve inches high, slender, bifid at the summit, mostly with a single flower on one of the branclies; leaves one to two inches long, acute at cach end, the two lower leaves on the flower-bearing branch mostly opposite, with the peduncle opposite the lower one, and immediately bencath the other. Ferianth three qiuarters of an inch in length. (Darlington's Flora Cistrita. Sce also Gray's Mamual of the Botany of the Northern Unitcl States, and Wood's Class-Book of Botany.)

(2) UR pretty Bell-Wort is sure to greet the wanderer, who, Les when

"__ May, with life and music,

The blooming valley fills, And rears her flowery arches

For all the little rills,"

has strolled out into the shady recesses of the forest for the purpose of gathering the early spring flowers. It is by no means a showy plant, but it has so many things to say to us, and all these things are so very interesting, that there are probably only few persons who would not care to join us in our imaginary talk with it.

But before we proceed we must stop to pay a compliment to our artist, the accuracy of whose drawing is attested by Dr. Darlington's description. In fact, one might almost think that the artist had the description before him while making the drawing, although it is in reality much more likely that he never saw it until he had a chance of reading it at the head of this chapter. There is the alternate character of the stem- 
leaves, with the addition of four abortive leaves or shcathing scales not noted by Dr. Darlington; and there are also the bifid stem, the baren branch, and the opposite leaves with the solitary flower. So far one might expect of the artist that he would not go wrong, if he were at all a fair copyist from nature. But the drawing also plainly shows the peduncle appearing just under one leaf and opposite the other, and this is so slight a characteristic that it would probably escape the notice of most observers.

One of the interesting little stories which our plant tells us relates to its flower. While many of its allies have numerous flowers on their stems, our Uvularic sessilifolic has only one, but in spite of this apparent poverty it thrives as well as any of its neighbors. With its single seed-vessel, filled with comparatively few seeds, the specics is distributed over as wide an extent of country, and is just as abundant in most of the localitics in which it grows, as those specics which enjoy what we should suppose to be the greater advantage of innumerable seeds. The rapidity with which it docs its work is also worth noting. Very shortly after the flower opens, its pistil is fertilized, and the perianth falls. Our plant, morcover, seems to get none of the benefits that are supposed to follow an occasional cross with pollen from a distant individual; for at the early season of the year when it flowers, there are but few winged insects in the cool, damp woods, and even these few are not likely to be allured to the blossoms, as they are hidden by the plant's own foliage, and have neither lively color nor swect perfume to make them attractive. The wind, also, can scarcely help them to foreign pollen; for Zephyr dreads to walk in the still recesses in which the Uvularia scssilifolia grows. Still, the greatcr number of the flowers scem to bear seed, and it is quite probable, therefore, that the plant is a sclf-fertilizcr. In vicw of the fact that this little flower can do so well with so small an amount of matcrial, it becomes an interesting question to ask why such an immense amount of effort is spent on the numer 
ous flowers and secds of allied species. The only possible answer appears to be that Nature makes use of this secming over-production in other directions, and that no one thing must be looked upon as working selfishly for its own good alone, but rather as an active member in the great whole of the animal and vegetable creation.

Uoularia may also serve to show the artificial character of even the best of so-called natural systems in botany. The order Liliacce is distinguished from Mclanthacce chiefly by the styles. These are so united in Liliacce as to look like a single style, the only indication of the presence of several styles being noticeable in a slight division at the apex, while in Mclanthacce they are clivided down to the ovary. In Uouluric the styles are also divided to such an extent that some botanists consider it a melanthaccous genus. In Lindley and Moore's "Treasury of Botany," for instance, we read: "Uvularia is a genus of Mclanthacea, and is the type of the suborder Uvularia, which is intermediate between the true MIclanthacce and Liliacca." Our American authors, however, such as Dr. Gray and Prof. IVood, place the Uvularia in the order Liliacce, subsection Uvularica, and we have ourselves adopted this classification.

In former times the Uiularias, as well as many allicd genera, were classed together with Polygonatum, or Solomon's Seal, which is another genus of the order of Liliacce. Linnxus, however, divided this genus, and gave our plants a separate place in the system under their present name, borrowing the latter, as we are told, from John Tragus, who wrote a history of plants in 1552. The Uvularia of Tragus appears to have been a sort of Campanula, or Bell-Flower, and it is probable that the common name of our plant, Bell-Wort, is derived from its early association with the Bell-Flower family. The name is certainly a very appropriate one, so far as the flower is concerned, as this latter is more truly bell-shaped than many of the real Campanulas. Another common name quoted by some American authors is Wild Oats, but there 
seems to be no meaning to this name, and it might as well be dropped.

The botanical name, Uvularia, puzzles the commentators. Prof. Wood says that the name is from the Latin zuvula, the palate, because "the flower depends like that organ." Dr. Gray, in his "Manual," gives the same etymology; but in "Field, Forest, and Garden Botany," he adds that the application is obscure; and a similar statement is made by most authors. It seems much more probable, however, that the name is derived from uvula, a little grape, as in many of the plants which, like our present species, were once classed with Polygonatum, the fruit is a berry, bearing some resemblance to the berries of a grape.

The Sessile-Leaved Bell-Wort does not seem to extend southward below South Carolina, but towards the northeast it is found up to and even beyond the limits of the United States. Westward it is found in the same latitudes, until it reaches our western desert. It is not, however, included in $\mathrm{Mr}$ Arthur's list of Iowa plants, although it is mentioned by Dr. Parry in Owen's Geological Survey of Iowa and Minnesota. It is reported in Nebraska by Prof. Aughey, and it appears also in Arkansas, according to Prof. Lesquereux, but has not yet been found in the intervening state of Kansas.

Explanation of the Plate - 1. Complete plant. - 2. Outline of a leaf, somewhat enlarged. - 3. Seed-vessel, nearly mature. - 4. Cross-section of seed-vesscl. 


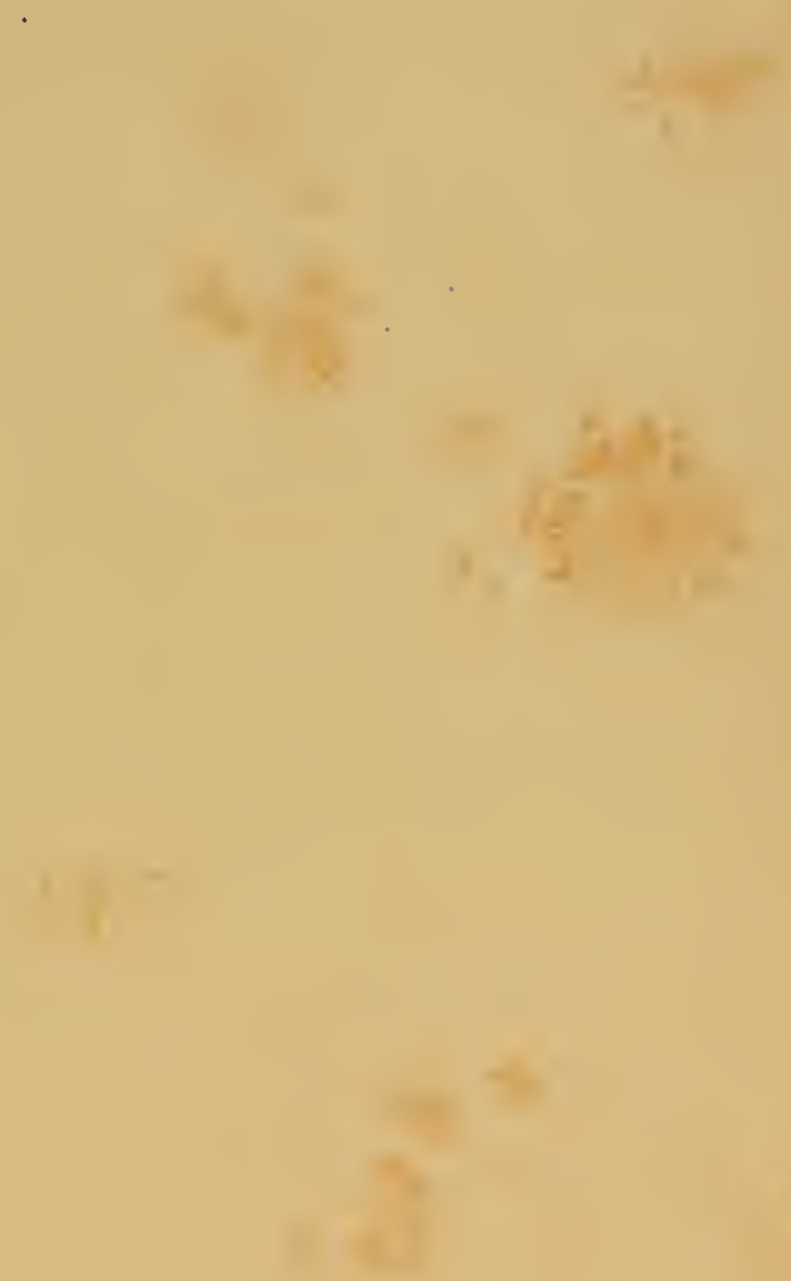




\title{
ASPLENIUM EBENEUM.
}

\author{
EBONY SPLEENWORT.
}

NATURAL, ORDER, FILICES. (POLTPODIACEE)

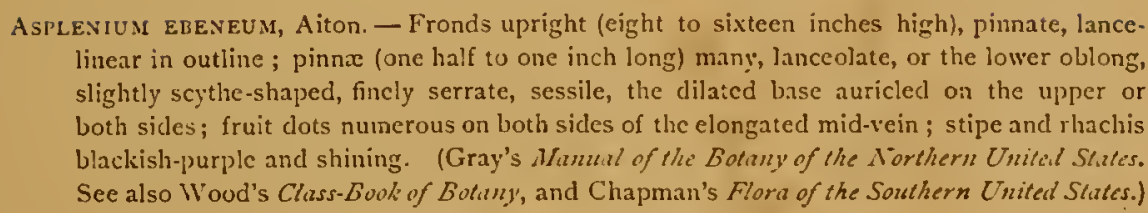

"'T is sweet, in the green spring.

To gaze upon the wakening fields around;

Birds in the thicket sing,

Winds whisper, waters prattle from the ground;

A thousand odors rise,

Breathed up from blossoms of a thousand dyes."

9.7. VERY one who is fond of wild flowers, whether it be as a 9. botanist in love with the "amiable science," or simply as a collector, and an admirer of beauty for its own sake, has felt the glow which inspired Bryant to warble forth these lines, thrilling through his veins as the warm days of spring covered the bosom of mother earth with flowers. But flowers are frail things at the best, and, as the same poct says, -

"If man come not to gather

The roses where they stand,

They fade among the foliage;

They cannot seek his hand."

In this respect the student of cryptogamic botany - the division in which ferns are placed - has a great advantage over the admirer of phrenogamic, or flowering plants. For while the 
latter, in many cases, has to watch for the exact day of flowering of the species which he desires to observe, and a day more or less may spoil his hopes of being favored with a sight of the treasure, the collector of ferns is not thus limited in regard to time, as many of the plants which interest him furnish material for examination even before "green spring" has brought out the early May blossoms, and continue to do so long after the autumn flowers have faded. When everything in nature seems sad and dreary, and when (still quoting our favorite poet) -

"The South-wind searches for the flowers whose fragrance late he bore, And sighs to find them in the wood and by the stream no more,"

the cryptogamist at least may be happy, for the woods still abound with what he seeks, and even the rocks, although bare of flowers, are in many cases clothed with the objects of his love.

The interest in ferns has greatly increased of late years, and they are now cultivated to an extent unknown before. And this is not to be wondered at, as ferns have a beauty of detail, and usually a gracefulness of form, which commend them highly to a refined taste. The species with which we are now concerned is not, however, a type of the highest beauty in this class of plants. But to the lover of ferns it is nevertheless welcome, as it is generally to be found in those locations in the Eastern States where a fem is at all likely to grow, with a decided partiality for growing on shaded walls, or on rocks in the deep recesses of the forest. The writer of this has seen many a hundred square feet of "dry wall," laid without mortar, so completely covered over by the foliage of this little plant as to rival the most romantic of the ivy-clad ruins of the Old IVorld. In such dry situations the fronds are not as rich in their foliaceous portions as when the plants grow in more favorable situations, with richer soil. The specimen represented on our plate grew on a dry wall, and we have selected it purposely, because the more overgrown specimens are generally chosen for illustration, and this very common 
form is overlooked. We may remark in passing that this fault is frequently found in works on wild flowers. The tendency always is to select specimens of extraordinary development, so as to make a "pretty picture." But such illustrations are apt to leave a wrong impression on the mind of the reader, and we have endeavored to avoid falling into the same mistake by carefully selecting specimens which will show the average condition of the plant, and such as the collector is likely to meet with in the great majority of cases. To give an idea, however, of the more symmetrical character of the best.grown specimens, we have added an enlarged drawing of a pinna from one of the larger-fronded forms (Fig. 2). It will be noticed how well the gentle curve at the apex harmonizes with the main outline, and how artistically the somewhat lunate or crescent-shaped sori are disposed between the almost parallel lines of the pinna. And not only are these parallel lines relieved by the curve described by the indusium, or thin membrane covering the sporangia, but this monotony is still further broken by the curves of the veins on which the fruit-dots are borne. It is difficult to conceive of a design more expressive of combined strength and elegance.

The variations in the size of the fronds, and in the length, breadth, and general outline of the pinne of Asplcuium cboncum are often so great as to mislead the student into believing he has found another species. But a close examination of the veins and the position of the fruit-dots will generally lead to a correct decision; for these two characters are usually constant, and will correspond to the typical form, however great may be the variation in the general appearance of the whole plant.

Aiton, in describing our species, says that the fruiting specimens are found in September, while according to Darlington they must be looked for in Nay. The truth is, that they may be found at any time between these periods. About Nay the new growth appears, and the old begins to decay; but the latter does not disappear entirely until about September, by which time the new fronds have perfected their fruit. 
The ancient classical name Asplenizum, or Spleen.Destroyer, has, of course, no immediate connection with our harmless littlc plant, which is not found in Europe at all. The specific name, cbcncum, refers to the ebony-colored stems of the species, and is more apparent in its application, although it is not really characteristic of this fern alone, as many American ferns have stems quite as dark as those of the $A$. cbcneum.

The geographical range of our plant within the United States is confined to the eastern slope of the continent. Its western outpost, so far as we know, seems to be in the eastern part of Colorado, where it was found on the Green Horn, one of the peaks of the Rocky Mountains, by Rev. E. L. Greene, a very acute and observing botanist. The writer of this has seen specimens from Arkansas which had remarkably long and slender leaflets, not over one eighth of an inch wide. To the south it extends along the mountain ranges to Quito, and it is also found in South Africa. In its progress towards the west, it has not been found in Kansas, although, as we have just noted, it occurs in Coloraclo. East of Kansas it extends to the northeasterly part of the United States, and towards the southeast as far as Florida.

Asplcnium cbcucum will be found under several synonyms, even in comparatively modern botanical works. Swartz, a German author, who wrote on ferns in the carly part of the present century, called it $A$. polypodoides; and Michaux, the celebrated French collector and writcr on American plants, named it A. trichonanoides. Aiton's name, which we have given at the head of this chapter, is, however, in almost universal use at the present time.

Explination of THe Plite. - I. Full-sizcl plant, from an old wall in summer. 2. Enlarged pinna, taken from another plant in autumn. 


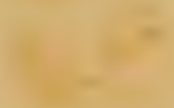




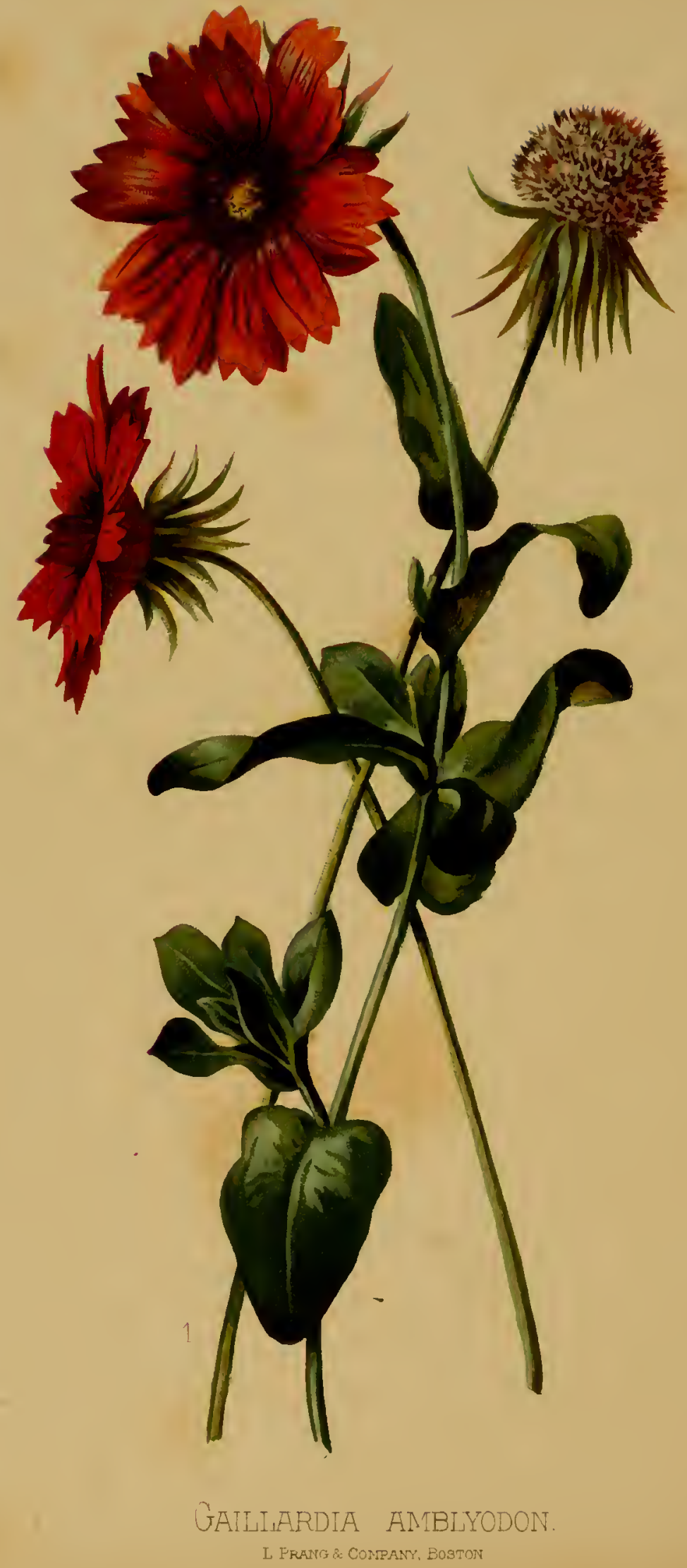




\title{
GAILLARIIA A M BLYODON.
}

\author{
BLUNT-TOOTH BLANKETFLOIVER.
}

\author{
NATURAL ORDER, COMPOSITE. (ASTERACE.E OF I.INDLEY.)
}

\begin{abstract}
Galli,ARdia amblyodon, Gay. - Annual; stems hirsute-pubescent, simp'c or branching; leaves sessile, denticulate, scabrous-pubescent, the lowest somewhat spathulate, the others oblong linear, somewhat auriculate at the base, and clasping; involucre hirsute, rather longer than the disk, the scales callous and appressed for ncarly half their length; corolla of the disk with short, triangular, rather obtuse teeth; chaff of the papjus lanceolate; fimbrilla of the recepiacle aristiform, unequal, not dilated at the base, mostly longer than the achenc. Stem ten to eighteen inches high. Rays about twelve. (Torrey and Gray's Fora of North slmerica.)
\end{abstract}

AILLARDIA is one of those genera which we always take up with pleasure. It is a genus wholly confined to the United States, and therefore commends itself especially to a work devoted to plants indigenous within this geographical area. While many of our native plants have been familiar to botanists for nearly two hundred years, the Gaillardias can only boast of a history embracing about half that time, as the first known species was described in I 756 , by Fougeroux, in the "Memoirs of the Paris Academy of Sciences." The first living specimens were introduced into France the year following, from what was then the French territory of Louisiana, by M. Thouin, a professor of agriculture in Paris. Fougeroux named the plant in honor of a M. Gaillardet, who is said to have been "a patron of botany." Lamarck, however, writes Galardia, and this orthography was adopted in many English works of the past generation, and also by our own Nuttall.

The original species described by Fougeroux was Gaillardia pulchella. Being a somewhat variable plant, it received different names from the botanists who observed its several forms, and 
hence we find it under the names of $G$. bicolor, G. amara, and $G$. altcrnifolia, the last of these designations being the one commonly used by English authors at the beginning of the present century. For many years the $G$. pulchclla was the only species known, but new ones were discovered as the knowledge of our western country increased, and several species have been described only quite recently. Our present species was named Gaillardia amblyodon, by Gay, also a French botanist; and his description, first published in the "Annales des Scicnces Naturelles," and aclopted by Torrey and Gray, we have placed at the head of this article. A further account of the plant, illustrated by a plate, is given by Dr. Gray in his "Chloris Boreal:-Americana." The specimens which served Dr. Gray in the proparation of this account were raised in the Cambridge Botanic Garden in 1845 , from seeds collected in Texas by Lindheimer, and this fact shows that it had then only recently been made known. We are indebted to the same institution for the plant from which our drawing was made.

Our species does not seem to be very abundant, as it is recorded in but few collections, although Dr. Gray says that it is a much ranker grower than G. pictu. The same authority also informs us that the fruits of the disk-flowers have awns, while those of the ray are awnless, and that "the specific name was chosen by M. Gay to express this peculiarity." It seems to us, however, that this name rests upoin a different basis. The description notes that the petals of the disk-flowers have "short, triangular, and rather obtuse teeth"; and it is this character which is expressed by the adjective amblyodon, as this is composed of two Greek words signifying respectively "blunt" and " tooth."

Mr. Vick tells us that in the settled parts of Texas, where some of the species are found wild, the Gaillardia is known as the "Blanketflower." We have adopted this name (although it does not seem to be particularly suggestive or appropriate), because the flower has no other common name, and because it 
is an evil to multiply synonyms. The somewhat differently colored species, commonly grown in English gardens is popularly known as the Golden Fleece, and this name, taken in connection with the American name, which certainly seems odd cnough at first sight, may afford a key to the meaning of both. There is a certain relationship between the Golden Fleece and a blanket, both of them being woolly, and it is evident, therefore, that the people of the wild Texan prairies, as well as the owners of the English gardens, were forcibly struck by the thick, woolly texture of the ray petals of our flower, and that they strove to cxpress this character in the popular name.

The Gaillardia amblyodon is generally looked upon as a very beautiful flower; but it seems to us that it can hardly be called beautiful, in the strict sense of the term, although it is certainly gay and showy enough. The scalloped edges of the corolla are too irregularly toothed to harmonize well with the general circular outline of the flower, and they are therefore rather a drawback than an aid to its beauty. The color of the petals is, no doubt, beautiful in itself, but there is too much of it. As a mere matter of beauty in lines and proportion, the mass of tapering involucral scales, surmounted by the globular head of halfmatured achenes, filled with minute detail (see Fig. I), is a far more artistic study than the flower itself.

The involucral scales just alluded to are very interesting, morphologically considered. The large number of these scales implies the transformation of many series of verticils of normal leaves in the production of one complete involucre, and it is curious to note that they have all retained very nearly the same size and texture, - an occurrence which it is by no means common to find among composite plants. The leaves have also managed to prescrve a comparatively uniform character in their advance along the stem towards the point where they were finally changed to involucral scales, and the two facts, considered together, are evidence of the suddenness of the change.

The Blunt-Toothed Blanketflower, like some of the other 
species of Gaillardia, is an annual; but it is very easily propagated by cuttings, and in this way one individual can be continued for years, or even indefinitely. Flower gardeners, indeed, usually prefer plants raised by cuttings to those raised from seed, as the former are more floriferous, and come into bloom earlier in the season. The fact that annual plants can be made permanent by being propagated from year to year by cuttings, is in itself very interesting, as it shows that the difference between an annual and a perennial plant is very slight, physiologically. There is vital power enough in the branches, even of annuals, to continue cell-growth indefinitely; but the roots do not receive their full share of the benefits from leaf action, the food manufactured by the leaves being cxhausted in the production of the flowers, and the roots are therefore too weak for permanence.

It would be well worth while to take the Blanketflower in hand, with a view to the production of what are technically known as double flowers. Among composites the so-called double flowers are not double, however, in the sense in which a rose or a carnation is cloublc. In the case of these latter plants the stamens change to petals; in the composites the corollas of the small disk-florets, which are normally tubular, are changed into strap-shaped corollas, similar to those of the ray flowers. It is very likely that this change might be brought about in our Gaillardia.

So far as we know, our species has only been found in Texas, where it grows in sandy, gravelly soil along the Brazos. The home of the whole genus, indeed, seems to be in Texas and the dry territory immediately to the north and west of that state.

Under cultivation the plant continues in bloom from June until frost sets in.

Explanation of thf. Plate. - I. Flower-shoot terminated by a half-mature head.2. Flower-shoots in full bloom.

(NOTE. - We have had room in the plate only for the upper portion of the flower-stems. The lower and younger would probably be more hirsute, and the leaves more denticulate than shown in the plate.) 



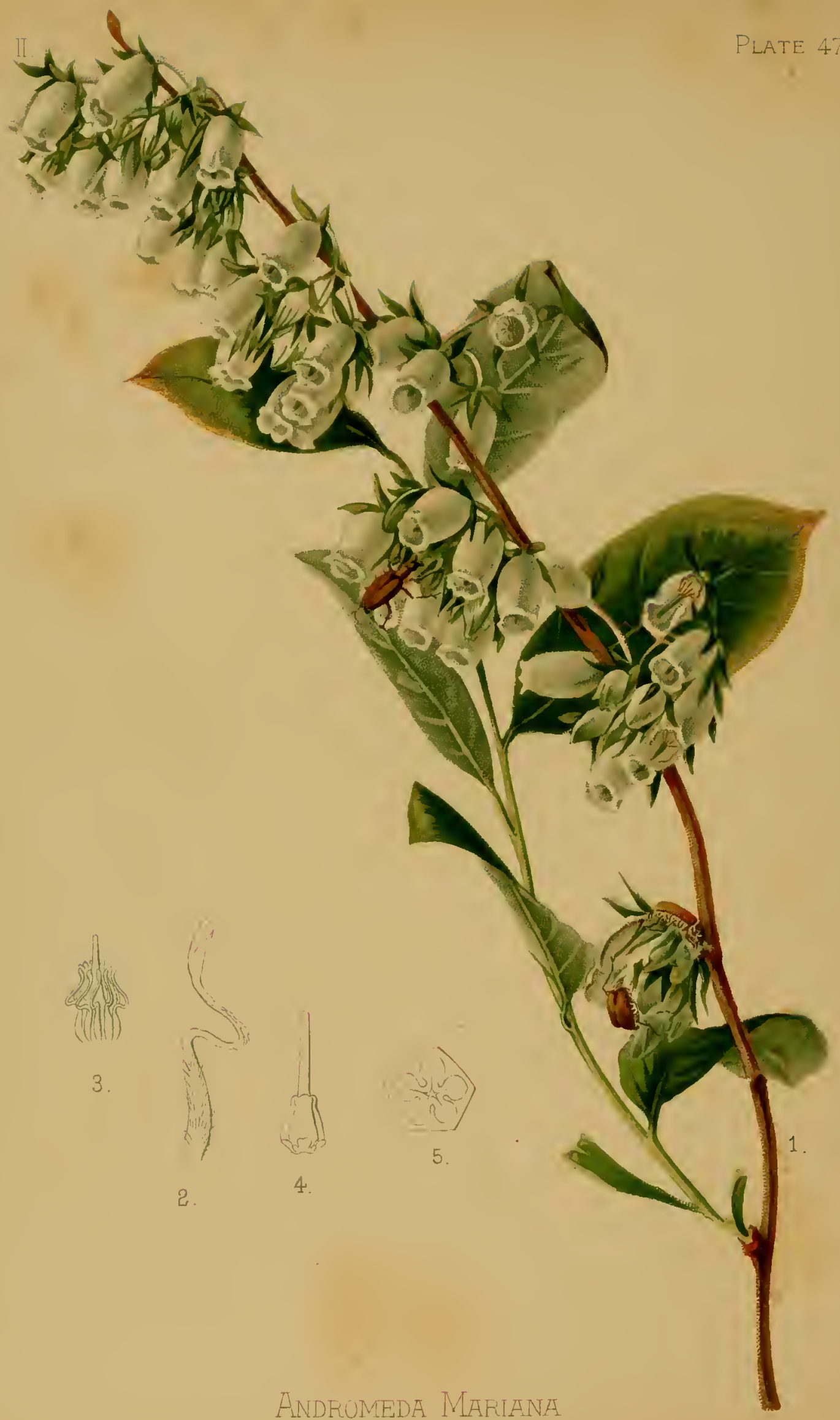




\title{
ANDROMEDA MARIANA.
}

\author{
STAGGER-BUSH.
}

NATURAL ORDER, ERICACEA.

Andromeda Marians, Linnaus. - Glabrous, or slightly pubescent, two to four fcet high; leaves oblong or oval, obtuse or acute at buth ends, entire, loosely veiny (one to three inches long); fascicles of nadding flowers raccmose on naked shoots; corolla cylinclraceous-campanulate, with slightly narrowed orifice, white or pale rose color (almost half an inch long); filaments hairy outside, their very small setuse appendage below the sumnit occasionally obsolete or wanting; capsule ovate-pyramidal, truncate at the contracted apex; the placente low down. (Gray's Symoptical Flora of North Ameraca. See also Gray's Manuml of the Botuny of the Northern L'nitid Sfates, Chapman's Florat of the Sonthern United States, and Wood's Class-Book of Botumy.)

NDROMEDA was a fair Ethiopian princess, who, according to the pretty story told by Ovid in the fourth book of his "Metamorphoses," was rescued from a terrible fate, and afterwards married by Pcrseus, the celebrated Greek hero. It is, of course, impossible to decide at this late day whether our princess had the proverbial Ethiopian skin, or whether she was "fair" in the Caucasian sense. But, however that may be, our poets and painters represent her as having been among the fairest of the fair; and if this be true, she certainly would have no reason to be ashamed of her namesake, Andromeda $M a$ riana, which is one of the purest and fairest of the princesses of the kingdom of Flora. Our picture is a good representation of the flower, but no artist can do justice to its beauty as seen growing in favorable seasons in the rich, peaty, half-swampy barrens of New Jersey. Snow is white, but the whiteness of these flowers excels it, owing to the delicate, waxy texture of their corollas. In Pennsylvania, where the plant is generally found in dryer soil, or sometimes even on rocks, as for example 
on the banks of the Wissahickon, near Philadelphia, the flowers are not so large nor so abundant, and they often have a pink tinge, which gives them a somewhat faded look. Still, even these Pennsylvania specimens are regarded as very beautiful, although they cannot lay claim to all the perfections of those of New Jersey growth. The plant from which our drawing was made came originally from the last-named state, and has been growing for some years in the writer's garden, in ordinary, light garden soil. It thercfore represents about the average condition in which the collector of wild flowers is likely to find the species, and this is preciscly the condition which we prefer for our work. We purposely avoid cxtraordinarily beautiful or abnormally developed specimens, as the reader might be disappointed in not being able to find anything which equals them in nature.

The genus Andromeda is, in the main, an American one, and comprises quite a number of species. Of all these, our Andromeda Mariana has the most beautiful flowers, in this respect rivalling, in size as well as in appearance, some of the famous heaths of the Cape of Good Hope, which are so much sought by cultivators. The habit of the plant, on the contrary, is not very beautiful, and in this particular the species is inferior to others of the same genus. Its growth is erect and sparse, and the leaves are deciduous; and as the flowers open before the leaves and branches are well devcloped, the whole plant has the appearance of a good task left unfinished.

The original Linnean genus of Andromeda was divided into several genera by succeeding botanists, and among them there was onc named Picris, and established by Don. Most of these genera, however, have been abandoned, but some of their names have been retained as sectional names by Dr. Gray, who places our species in the section Picris of the genus Andromeda. Don himself did not notice the relationship of this plant to his genus, but placed it in Lyonia, another genus established by Nuttall, and as Lyonia Mariana it is still referred to by many European writers. In Dr. Gray's works, however, Lyonia is 
only retained as a section of the genus Andromeda, and does not even comprisc our species.

The Andromadi Mariana was well known to our earlier botanists. Plukenet refers to it as a "Maryland shrub, with the leaves of a Euonymus and the flowers of an Arbutus," not an unapt description. It was also among the plants sent by Clayton to Gronovius, and according to Aiton it was first introduced into England, in a living state, in 1736 , by Peter Collinson, in whose garden it was cultivated.

Although so beautiful as a flower, our species has rather an uncertain reputation. Dr. Darlington say's, in his "Flora Cestrica": "This shrub is very common in New Jerscy, where the farmers think it is injurious to sheep, when caten by them, producing a disease callcd the staggcrs." This popular belicf has griven to the Andromedi Mariana its common name, which is Stagger-Bush, a fact for which we are rather sorry, as it is probable that the plant is not so injurious as it has been supposed to be. Careful investigator that he was, Dr. Darlington himself cxpressed some doubts as to its noxiousness, in lis "Agricultural Botany." Dr. Peyre Porcher, however, is also suspicious of the species. He says that "the honey which the bees cxtract from these flowers is slightly poisonous," and refers to "Nicholson's Journal" as his authority. Similar charges have been made against the Azalca, Rhododendron, and Kalmia, all of them cricaceous plants, and it is barely possible that the suspicion has been transferred from one of these plants to the other, without any very special foundation. Dr. Gray, in his recently published "Synoptical Flora," as well as in his "Nanual," remarks that it is said to be poisonous to "lambs and calves," but he does not include "sheep," to which, according to popular belief, as we have seen, it is said to be specially injurious.

In regard to its medicinal qualities, we are informed by Dr. Titford, in his "Hortus Botanicus Americanus," that the Andromeda Mariana "is a cure for the ground or toe-itch." Dr. 
Porcher says that "it is employed in domestic practice as a remedy for herpes," which is an itching eruption of the skin.

The Stagger-Bush is native in all the seaboard states from Rhode Island to Floricla, and according to Dr. Gray it has also been found in Tennessee, and even as far west as Arkansas. The ease with which it grows in the writer's garden, in ground mixed with a large quantity of small stones, shows that it is very well adapted to general cultivation, and that the soil will need no special preparation to receive it.

According to Dr. Titford, the Stagger-Bush is also known by the names of Moor-Wort and Wicke, the last of which, curiously enough, is the German common name for several species of leguminosæ.

Explanation of the Platr. - I. Flowering branch. - 2. Twisted stamen. - 3. Arrangement of the stamens in the flower. - 4. Gyncecium. - 5. Cross section of the ovary. The insect seen on the plant is the Macrodactylus subspinosus, or rose-beetle. 


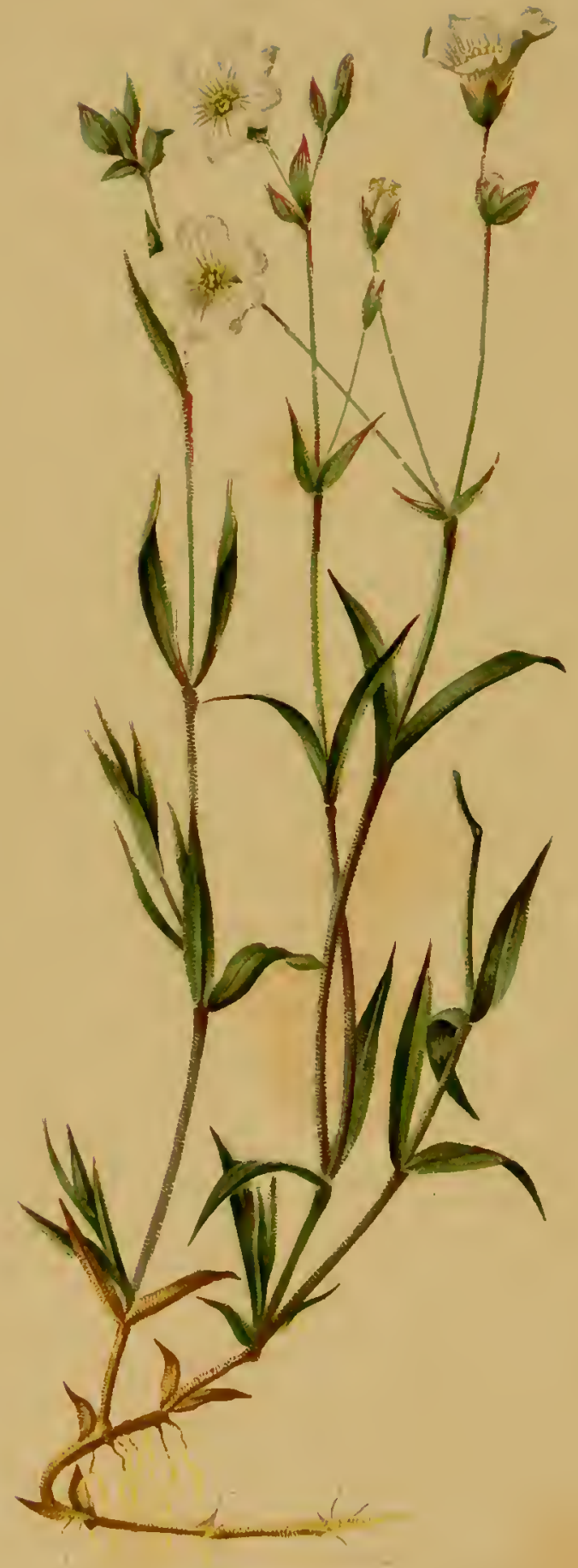




\title{
CERASTIUM ARVENSE.
}

\author{
FIELD MOUSE-EAR CHICKWEED.
}

NATURAL ORDER, CARYOPHYLLACEA.

\begin{abstract}
Cerastium aRVense, Linmæus. - Tubescent, somewhat cxspitosc; leaves linear-lanceolate, acute, often longer than the intcrnodes; cyme on a long terminal peduncle, forr-flowered; petals more than twice longer than the calyx; capsule scarcely cxcccling the scpals. Flowers white, rather large. (Wood's Cliss-Book of Bohuny. See also Gray's Mrimunt of the Botny of the Northern United States, Chapman's Flura of the Sonthern L'nited Statis, and Brewer and Watson's Botuny of Califorstia.)
\end{abstract}

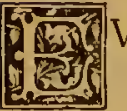

VERY traveller knows how pleasant it is to meet a friend in a foreign country and far away from home. A similar sensation is experienced by the botanist when he meets with an old floral acquaintance in a strange land, or in some unexpected place. The flower acts like the well-known human face. Old associations are recalled, old scenes come back to the memory, and for the moment all else is forgotten in the recollection of "home, sweet home." The writer of this, in the summer of 1871 , had just such an experience with the subject of the present chapter. He had often admired the plant with its chaste flowers, as it adorned the wooded and rocky banks of the Schuyllill, and other places in the Atlantic States, where, in the lines of Bryant, these -

"fair white blossoms of the wood

In groups beside the pathway stood,"

and the reader may therefore imagine the pleasure with which the plant was hailed, when it was found one evening as the writer and his little party were preparing to pitch their tent for the night on their camping-ground in Bergen Park, Colorado, 
seven thousand feet above the level of the sea. One of the plants was taken up like a little treasure, carefully nursed in damp grass and fern leaves, instead of moss, as that happened to be scarce just then, and was brought to Philadelphia, and from this plant our drawing was made.

But although the unexpected finding of Cerastium arvonse under these circumstances had the effect of an agreeable surprise, it is yet hardly to be wondered at that it should occur in such an elevated region, for it is indeed an Arctic plant, like many of the other species of the genus Cerastium. On one of the expeditions made by Sir John Franklin it was found almost up to the region of perpetual ice. It is a well-known native of Siberia, and is included in the floras of nearly all northern countries. In our own country it extends south to Georgia on the Atlantic slope, and reaches California on the Pacific. In the last-named state, according to Messrs. Brewer and Watson, it is, however, found only sparingly, occurring at the Russian Colony, and at Noyo, in Mendocino County, in sandy fields among shrubs, and on the East Fork of Eel River. The "Botany of California" regards our plant as closely related to another species, C. oblongifolizm, which is found in the Eastern States; and if both of these forms should come to be regarded as mere varieties of one species, the geographical area of Cerastium arvonse would have to be extended considerably. The C. Willdenoviz of the Chilian Alps, the C. tomentosum, from the mountains of France, and the $C$. Bicberstciniz, from the mountains of Russia, are also very closely related to our species, the two latter (which are cultivated in gardens) so closely, indeed, that it is difficult to separate them from Cerastium arocnse by any fixed botanical characters. Our species, however, blooms two wecks earlier than the C. tomontosum, and this is an advantage which will recommend it to the cultivator. In Philadelphia gardens it is usually in bloom by the end of April. The plant shows its Alpine origin by dying away completely as soon as the hot weather approaches; but with the return of cool autumn 
evenings it makes a nice green, moss-like growth, which it retains all through the winter, ready for the early bloom of spring. It makes an excellent basket or vase plant for cool and shady situations, or for cool rooms or greenhouses during the winter season.

The generic botanical name Cerastizm is a very old one, and is derived from the Greek keras (Latin comm), a horn, in allusion to the seed-vessels, which assume a shape somewhat resembling a horn as they approach maturity. The specific name, arocnse, from arvum, a field, was probably chosen by Linnaus because he found the plant growing in fields. In our country, however, it is not often found in such locations; and, indeed, with the exception of sandy fields in New Jersey, the writer has never seen it elsewhere than on barren rocks and in waste places among scattered trees and bushes generally.

The common name of Cerastium arvense, or Field MIouseEar Chickweed, is apt to mislead, cspecially as it is often abbreviated to Field Chickweed; for our species, as we have just seen, can hardly claim any spccial connection with the fields, while the common Garden Chickweed, so well known as the food of canary bircls, is frequently found there. The true Chickweeds, indeed, are not consiclered Cerastiums at all by modern botanists, but are classed as Stellaria; and our present genus Cerastium ought not, therefore, to be called Chickweed. But as in olden times these two classes of plants used to be looked upon as belonging to the same genus, the popular name has clung to both, in spite of the efforts of botanists to separate them. The appellation Mouse-Ear is derived from the general resemblance of our plant to some species of Myosotis, or Forget-mc-not, which used to be called by that name from some fancied resemblance in the leaves of several of the smalter species to the ear of a mouse. This resemblance is, howerer, totally wanting in most of the Mouse-Ear Chickweeds, and the explanation here given only tends to show how widely names may be estranged from their early associations in the course of time. 


\section{2}

CERASTIUM ARVENSE. - FIELD MOUSE-EAR CHICKWEED.

Our Corastium arocnse varies considerably, and hence several forms, which, with our prescnt knowledge of the range of variation, are considered as nothing but varieties, have been described as separate species. Those students, therefore, who desire to look up the history of our plant will have to search for it under several names. Mr. Watson, in his "Bibliography," says that the C. clongatum and C. tcumifolizm of Pursh, as well as the $C$. Pcnnsyluanicum of De Candolle's "Prodromus," are all identical with the Ccrastizm arvense. De Candolle's species was founded on the narrower petals and the more rounded capsules of a form found in the state of Pennsylvania.

The Field Mouse-Ear Chickweed can be readily propagated for garden purposes by dividing the creeping root-stock. 


\section{SYSTEMATIC INDEX.}

RANunCulace.

Anemone nemorosa .

I. 21

Aquilegia chry'santlia

Thalictrum clioicum .

I. 25

Anemone patons, var Nuetalliana .

Anemone Caroliniana

Thalictrum anemonoides .

I. 49

I. 365

II. 117

\section{CAPPARIDACEe.}

Cleome pungens . . . . . . . . . . . . I. 149

VIOLACE:

Viola cucullata

Viola peclata

Viola sagittata.

\section{CARYOPHYLLACEA.}

Silene Virginica

Silcue stcllata.

Paronychia argyrocoma

Cerastium arvense

Portul.acaces.

Claytonia Virginica .

Talinum teretifolium

\section{157}

malvacez.

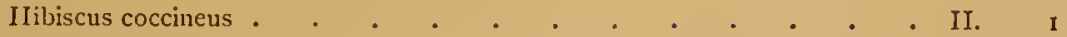

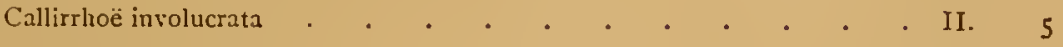

LINACER.

Linum perenne $\quad . \quad+\quad . \quad+\quad . \quad+\quad . \quad$ I. 117

VITACEIE.

Vitis indivisa . . . . . . . . . . . . . II. 2 I

\section{Celastrace.}

Pachystima Canb;i . . . . . . . . . . . . I. 173

\section{Legumiros.t. (FAbacter ; Parilionacea.)}

Tephrosia Virginiana . . . . . . . . . . . I. $8 \mathbf{~}$

Phaseolus diversifolius . $. \quad . \quad . \quad . \quad . \quad . \quad . \quad . \quad . \quad$ II. 16 ? 
ROSACEN.

Geum triflorum

Potentilla fruticosa . . . . . . . . . • . . I. I13

Rosa Carolina . . . . . . . . . . . . . . I. 169

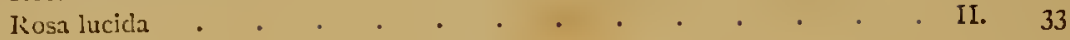

SAXIFRAGACE.T.

Saxifraga Virginiensis . . . . . . . . . . . I. 73

Crassulaced.

Sedum Nevii . . . . . . . . . . . . . I. $8_{5}$

MIFLASTOMACE $\pi$.

Rhexia Virginica . . . . . . . . . . . . II. 6 I

LYTHRACET.

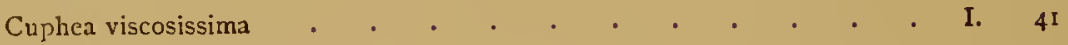

CACTACER.

Echinocactus polycephalus . . . . . . . . . . II I 29

RUBiacer. (LOGANiACE.t; Cinchonace..)

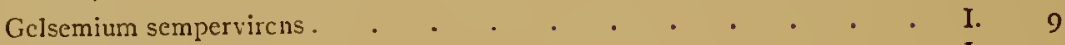

Houstonia carulea . . . . . . . . . . . . I. 97

Comrosita.

Actinomeris squarrosa . . . . . . . . . . . I. 153

Chrysopsis Mariana . . . . . . . . . . . . I. IS5

Antennaria plantaginíolia . . . . . . . . . . . II. 29

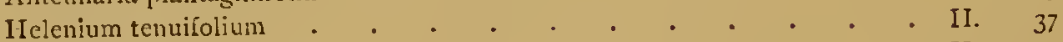

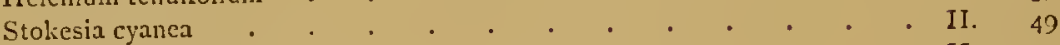

Helenium antumnale . . . . . . . . . . II. II3

Vernonia Noveboracensis . . . . . . . . . . II. I I I

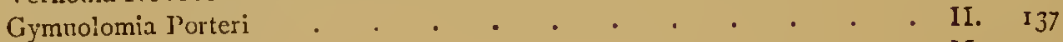

Helianthus Maximiliani . . . . . . . . . . . II. I45

Gaillardia amblyodon . . . . . . . . . . . II. ISI

CAMTANtLacer.

Campanula rotundifolia . . . . . . . . . . . . . II. 9

ERICACEA.

Arctostaphylos Uva-ursi . . . . . . . . . . . . . I. 77

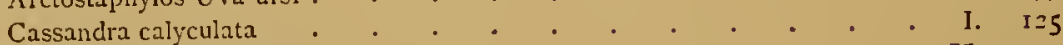

Vaccinium macrocarpon .

Pyrola elliptica. . . . . . . . . . . . . . . II. I25

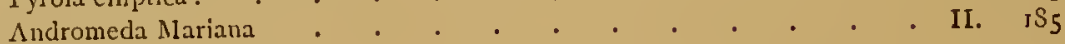

Priaidincet:

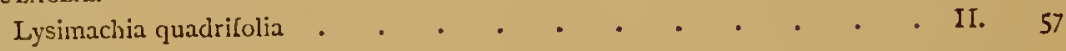

OrOBANCIIACEN.

Epiphegus Virginiana . . . . . . . . . . . . II. 93

SCROTILLARIACE

l'cdicularis Canadensis . . . . . . . . . . . I. 6 I

Gerardia pedicularia . . . . . . . . I. 133

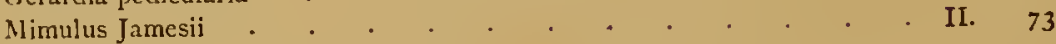


ACANTHACEE.

Ruellia ciliosa

II., 89

VRRBENACE $/$.

Verbena Aubletia . . . . . . . . . . . . II. Sı

LABIATE.

Scutellaria Wrightij. . • . • • • • • • • . II. 41

Collinsonia Canadensis . . . . . . . . . . . II. 165

POLEMONIACEA.

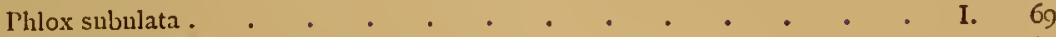

Phlox reptans : . . . . . . . . . . . . I. ISI

Convolvulaces.

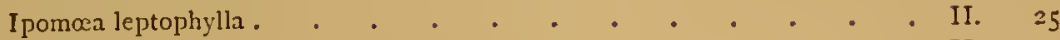

Ipomoca lacumosa . . • • • • • • • • • • II. 97

Gentianacese.

Limnanthemum lacunosum . . . . . . . . . I. 93

POLygonaceas.

Polygonum arifolium • • • • • • • • • • . II. 153

EUPHorbiacee. (BUXACEe OF MLULler.)

Pachysandra procumbens . . . . . . . . . . I. 29

Euphorbia corollata. . . . . . . . . . . . I. 109

ARACEA.

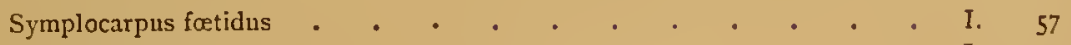

Calla palustris . . . . . . . . . . . . I. I05

Xanthosoma sagittifolia . . . . . . . . . . . . 1. 121

Orontium aquaticum $\cdot$.

ORCHIDACEA.

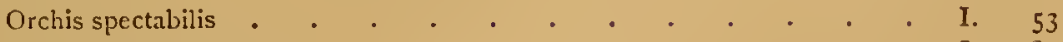

Platanthera fimbriata . . . . . . . . . . I. 89

Togonia ophioglossoides . . . . . . . . . . . I. I46

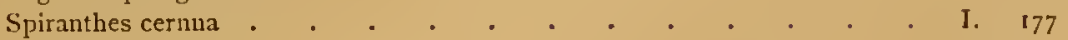

Calopogon pulchellus . . . . . . . . . . II. 10 I

Epidendrum conopseum . . . . . . . . . . . IL. I4I

AMARYLLIDACE.E.

Amaryllis Atamasco. . . . . . . . . . . . II. 69

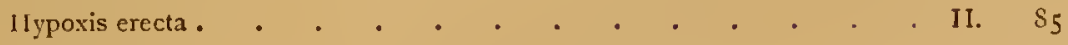

IRIDACEAs.

Iris versicolor . . . . . . . . . . . . . I. I41

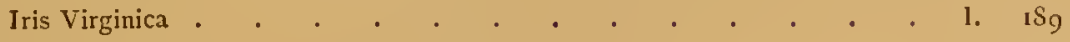

\section{LILIACE.E.}

Erythronium Americanum . . . . . . . . . . I. 65

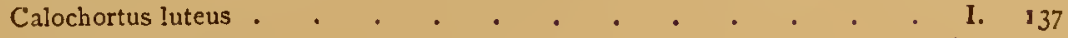

Brodiæa grandiflora . . . . . . . . . . . . II. 77

Uvularia sessilifolia. $. \quad . \quad . \quad . \quad . \quad . \quad . \quad . \quad . \quad . \quad$ II. 173 
Trilliace.e.

VIL. PAGE

- Medcola Virginica . . . . . . . . . . . . I1. 157

MELANTHACE.E.

IIelonias bullata . . . . . . . . . . . . I. 33

COMMELYNaceE.

Tradescantia Virginica . . . . . . . . . . . I. I

Cyperace.e.

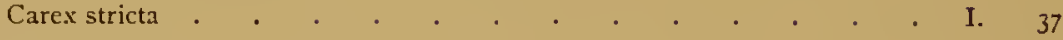

Filices.

Polypodium incanum

Asplenium Trichomanes

Asplenium parvulum

Aspidium acrostichoides

Polypodium vulgare .

Asplenium ebeneum .

Marsiliace e.

Marsilia quadrifolia.

II. 13 


\section{INDEX OF BOTANICAL NAMES.}

\begin{tabular}{|c|c|c|c|c|c|c|c|}
\hline \multicolumn{4}{|l|}{ A. } & & & & PAGR \\
\hline Actinomeris squarrosa & . & vol. & $\begin{array}{l}\text { PAGE } \\
153\end{array}$ & $\begin{array}{l}\text { Epiphegus Virginiana. } \\
\text { Erythrnnium Americanum }\end{array}$ & & II. & $\begin{array}{l}93 \\
65\end{array}$ \\
\hline A maryllis Atamasco & . & II. & 69 & Euphorbia corollata & . & I. & $\begin{array}{l}109 \\
109\end{array}$ \\
\hline Andromeda Mariana . & - & II. & 185 & & & & \\
\hline Anemone Caroliniana . & - & I. & 165 & G. & & & \\
\hline Inemone nemorosa & & I. & $2 \mathrm{I}$ & 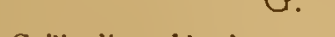 & & & \\
\hline Anemone patens, var. Nutta & alliana, & 1. & 49 & Gaillardia amblyodon . & . & II. & ISI \\
\hline Antennaria plantaginifolia & . . & II. & 29 & Gelsemium sempervirens & . & 1. & \\
\hline A quilegia chrysantha . & . & I. & 25 & Gerardia pedicularia . & . & I. & 133 \\
\hline Arctostaphylos Ura-ursi & . & I. & 77 & Geum triflorum & - & I. & \\
\hline stichoides & . & II. & 149 & Gymnolomia Porteri & . & II. & 137 \\
\hline Asples & . & II. & 177 & & & & \\
\hline rvulum . & . & II. & 65 & $\mathrm{H}$. & & & \\
\hline splenium Trichomanes & . & 1. & 161 & II elenium autumnale . & . & II. & 113 \\
\hline B. & & & & $\begin{array}{l}\text { Iuifolium } \\
\text { Iaximiliani }\end{array}$ & . & $\begin{array}{l}\text { II. } \\
\text { II. }\end{array}$ & $\begin{array}{r}37 \\
145\end{array}$ \\
\hline Brodiæa grandiflora & . & II. & 77 & Helonias bullata . & & I. & 33 \\
\hline & & & & $\begin{array}{l}\text { Hibiscus coccineus } \\
\text { Ioustonia cærulea }\end{array}$ & & $\begin{array}{l}\text { II. } \\
\text { I. }\end{array}$ & \\
\hline C. & & & & IIypoxis erecta & . & II. & \\
\hline alla & . & I. & 105 & & & & \\
\hline Jucrata . & . & 11. & 5 & I. & & & \\
\hline Calochortus luteus . & . & I. & 137 & Ipomœea lacunosa . & . & II. & 97 \\
\hline Calopogon pulchellus . & . & II. & IOI & Ipomera leptophylla & . & II. & 25 \\
\hline Campanula rotundifolia & . & II. & 9 & Iris versicolor & . & I. & $14 \mathrm{I}$ \\
\hline Carex strict & . & I. & 37 & Iris Virginica & . & I. & Isc \\
\hline alyculata & - & I. & 125 & & & & \\
\hline un arvense & . & 11. & 189 & & & & \\
\hline Chrysopsis Mariana & - & I. & I $S_{5}$ & L. & & & \\
\hline Claytonia Virginica & . & I. & I 57 & um lacunosum & & I. & 93 \\
\hline Cleom & . & I. & 149 & Linum perenne $\cdot$ & . & 1. & 117 \\
\hline Collinsonia Canadensis & . & II: & $\mathrm{I} G_{5}$ & Lysimachia quadrifolia & . & II. & 57 \\
\hline Cuphea viscosissima . & - & I. & $4 \mathrm{I}$ & & & & \\
\hline & & & & & & & \\
\hline & & & & olia & & 11 & 13 \\
\hline & & II. & 129 & Mimulus Jamesii & • & 11. & 157 \\
\hline pidendrum conopseum & - & 11. & $14 \mathrm{I}$ & Mimulus Jamesii . & - & II. & \\
\hline
\end{tabular}




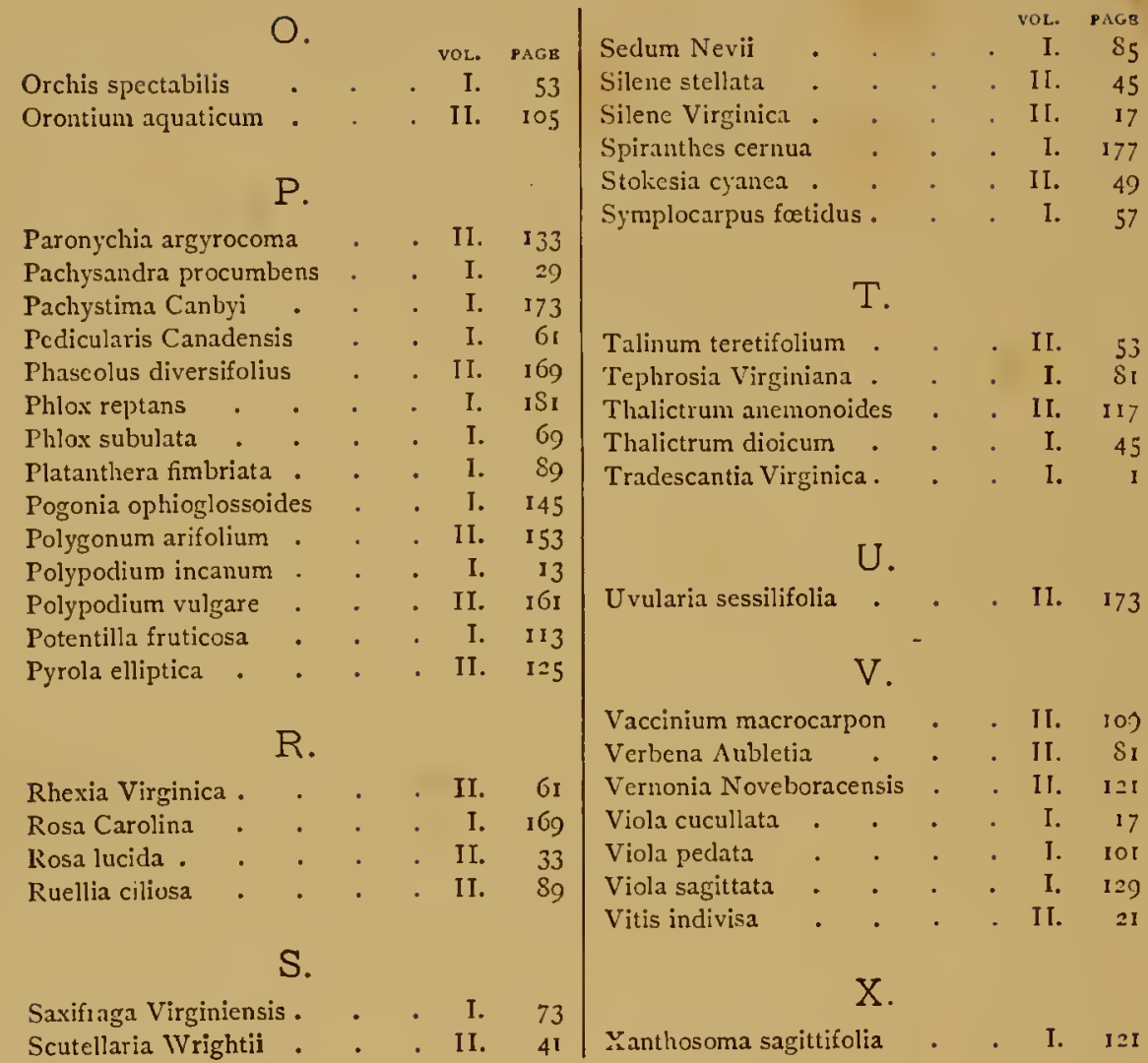




\section{INDEX OF COMMON NAMES.}

\begin{tabular}{|c|c|c|c|c|c|c|c|c|c|}
\hline & & & & & E. & & & & \\
\hline Actinomeris, Squarros & & . & . I. & I 55 & Everlasting, Mouse-Ear & . & - & II. & $\begin{array}{r}\text { PAGB } \\
29\end{array}$ \\
\hline Anemone, Caralina & & . & I. & 165 & & & & & \\
\hline Atamascu Lily . & & . & . II. & 6) & $F$. & & & & \\
\hline Avens, Threc-Flowere & & . & - $\quad \mathrm{I}$. & 5 & False Foxglove, Fern-Leave & & . & I. & 133 \\
\hline & & & & & Fame-Flower & & . & II. & 53 \\
\hline & 3. & & & & Flag, biue . & . & . & I. & $1.4 \mathrm{I}$ \\
\hline Dear-Berry . & & . & I. & 77 & Flat-Top . & . & . & I1. & 121 \\
\hline Beech-Drops & - & . & II. & 93 & Flax, Perennial & . & . & I. & 117 \\
\hline Bell-W ort, Scssile-Lea & wed & . & . II. & 173 & Floating IIcart · · & & . & I. & 93 \\
\hline Blanket-Flowcr, Jilunt & -Toot & thed & - II. & $I S I$ & Foxglove, Fcrn-Lcaved Fal & & . & I. & 133 \\
\hline Llucbell of Scotland & . & . & . II. & 9 & & & & & \\
\hline Blue Flag . . & & . & . I. & 141 & G. & & & & \\
\hline Dluets . • & & . & I. & 97 & & & & I & $\delta_{I}$ \\
\hline log- $\Lambda$ rum & . & . & I. & 105 & $\begin{array}{l}\text { Goat's Rue, Virginian . } \\
\text { Golden Club }\end{array}$ & & $\dot{.}$ & II. & $\begin{array}{r}81 \\
105\end{array}$ \\
\hline Boston Iris . & . & - & I. & $1 S_{9}$ & $\begin{array}{l}\text { Golden Club } \\
\text { Golden Star, Maryland }\end{array}$ & & $\dot{\cdot}$ & $\begin{array}{l}11 . \\
1 .\end{array}$ & $\begin{array}{l}105 \\
1 S_{5}\end{array}$ \\
\hline & C. & & & & Grass-Pink . . . & & . & II. & IOI \\
\hline $\begin{array}{l}\text { California Hyacinth, I } \\
\text { ered }\end{array}$ & .arge & -Flon & . & & $\mathrm{H}$ & & & & \\
\hline Campion, Starty . & & . & II. & 45 & Hedgelog-Cactus, Many-H & Ieadec & & II. & 129 \\
\hline Canby's Mountain-Lo & & . & I. & 173 & Hyacinth, Large-Flowered & Cal & & & \\
\hline Cassandra . . & . & . & . 1. & $1=5$ & fornia $\quad \cdot \quad \cdot \quad \cdot$ & - & - & II. & 77 \\
\hline Catchfly, Starry . & 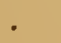 & . & . II. & 45 & & & & & \\
\hline Catchfly, Virginian & . & $\cdot$ & II. & 17 & I. & & & & \\
\hline Chickweed, Field Mo & use- $\mathrm{E}$ & & JI. & Is9 & Indian Cucumber & . & . & II. & 157 \\
\hline Cinque-Foil, Shrubby & & . & I. & 113 & Ipomoea, White-Star & . & . & II. & 97 \\
\hline Claytonia, Notch-Peta & lled & . & I. & I 57 & Iris, Boston . . & . & . & I. & IS9 \\
\hline Cleome, Prickly . & $\cdot$ & - & I. & I 49 & Iron-IVeed . . & . & . & II. & $1 \geq 1$ \\
\hline Club, Golden . & & . & - II. & 105 & Ivy-Grape, Entire-Ledred & . & . & Il. & $2 \mathrm{r}$ \\
\hline Collinson's Flower & - & . & - II. & 105 & & & & & \\
\hline Colorado Man-Root & . & . & . II. & $=5$ & J. & & & & \\
\hline Columbinc, Golden & . & . & . I. & $=5$ & & & & & \\
\hline Cranberry, American & . & . & . II. & 109 & Jasmine, Carolina & • & - & 1. & 9 \\
\hline Cucumber, Indian & . & . & - Il. & 157 & Jasmine, Ycllow . & $\cdot$ & & & 9 \\
\hline & & & & & & & & & \\
\hline Dog-Tooth Violet, $\mathrm{J}^{\prime}$ & llow & . & I. & 65 & Lidney-Dean, Diverse-Leav & & - & II. & 169 \\
\hline
\end{tabular}


L.

Ladies' Traces, Drooping-Flowered .

Leather-Leaf

Lily, $\Lambda$ tamasco . . . . II. 69

Loesestrife, Four-Leaved . . II. 57

M.

Maidenhair, English

Man-Root, Colorado . . . II. 25

Marsilia, Four-Leaved. . . II. I3

Meadow-Beauty . . . . II. 6I

Meadow-Rue, Early . . . I. 45

Meadow-Rue, Wind-Flower . . II. II

Monkey-Flower, James' . . Il. 73

Moss-Pink . . . . I. 60

Mountain-Lover, Canby's . . I. 173

Mouse-Ear Everlasting . . II. 29

N.

Nailwort • . • . . II. I33

Nuttall's Pasque-Flower . . I. 49

\section{O.}

Orchis, Great Fringed.

Orchis, Showy

\section{P.}

Pasque-Flower, Nuttall's . . I. 49

Pea, Hoary . . . . . I. SI

Phlox, Crawling . . . . I. ISI

Polypody, Common . . . II. IGI

Polypody, IIoary . . . . I. 13

Poppy-Mallow, Purplc. . . II. 5

Preacher in the Pulpit. . . I. 53

Pretty-Grass, Yellow . . . I. 137

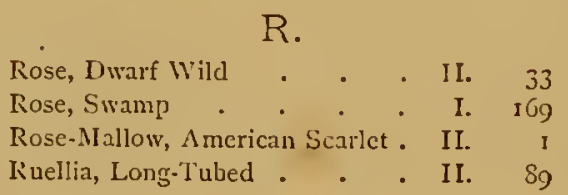

S.

Saxifrage, Early White - . I. 73 Shield-Fern, Christmas
VOL. P.IGB

Shin-Leaf . . . . . II. 125

Silverhead . . . . . II. I33

Skullcap, Wright's . . . II. 4I

Skunk-Cabbage . . . . I. 57

Snake-Mouth . . . . I. I45

Sncezewort, Autumn . . . II. II3

Sneezewort, Slender-Leaved . II. 37

Spleenwort, Dwarf . • • I. I6I

Spleenwort, Ebony - . . II. 177

Spleenwort, Smaller Ebony . . II. 65

Spider-Fiower . . . . I. 149

Spiderwort . . . . I. I

Spoonflower, Arrow-Leaved $\quad$ I. 121

Spring-D auty . . . . I. 157

Spurge, Flowering . . . I. 109

Stagger-Bush . . . . II. IS5

Star, Maryland Golden . . I. ${ }_{1} S_{5}$

Star, Stone-Mountain . . . JI. 137

Star-Grass . . . . . II. $8_{5}$

Stokesia, Blue . . . . II. 49

Stonc-Crop, Nevius' . . . I. 85

St^nc-Mountain Star • . . II. 137

Stud-Flower . . . . I. I. 33

Sunflower, Maximilian"s . . II. 145

T.

Talinum, Terete - • . . II. 53

Tear-Thumb, Ilalbercl-Leaved . II. I53

Thick-Stamen, American . . I. $\quad 29$

Tree-Orchis, Bartram's • . II. $14 \mathrm{I}$

Tussock-Sedge . . . . I. 37

V.

Verbena, Aublet's . . . II. $\delta \mathbf{I}$

Violet, Arrow-Leaved . . . I. 129

Violet, Bird's Foot . . . I. Iol

Violet, Common Blue. . . I. 17

Violet, Yellow Dog-Tooth . . I. $6_{5}$

\section{W.}

Was:-Wced, Dlue. . . . I. $4 \mathrm{I}$

Wind-Flower . . . . I. 2 I

Wintergreen . . . . II. I 125

Wood-Anemone . • . . I. 21

Waad-Betony, Common . . I. 61 




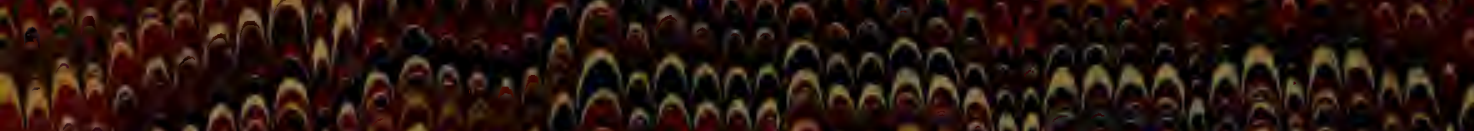

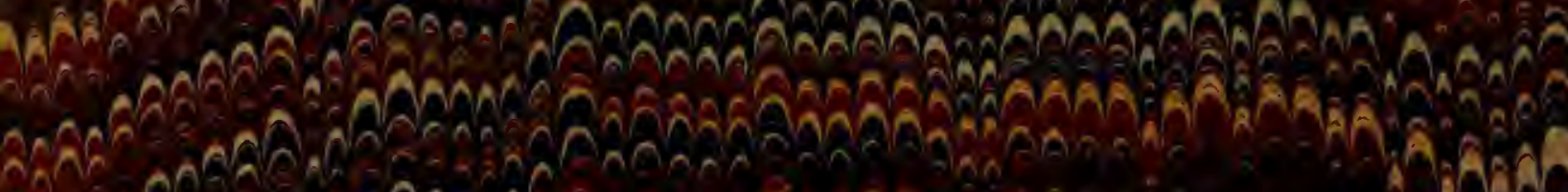

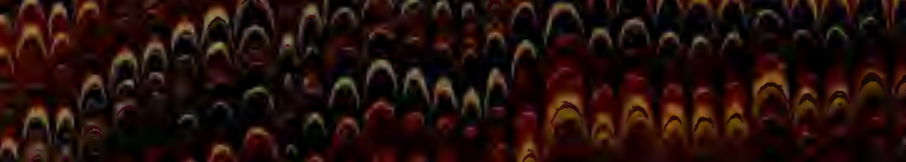

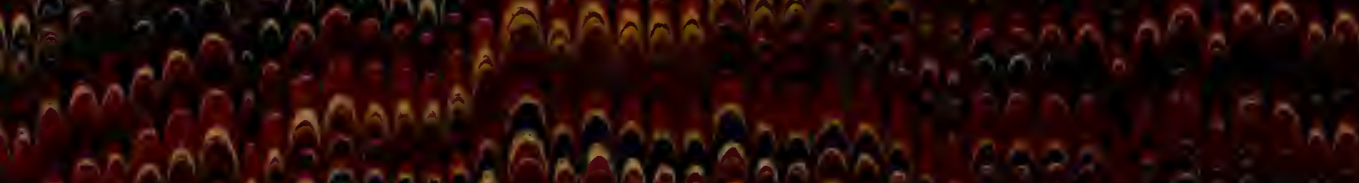
AANAC

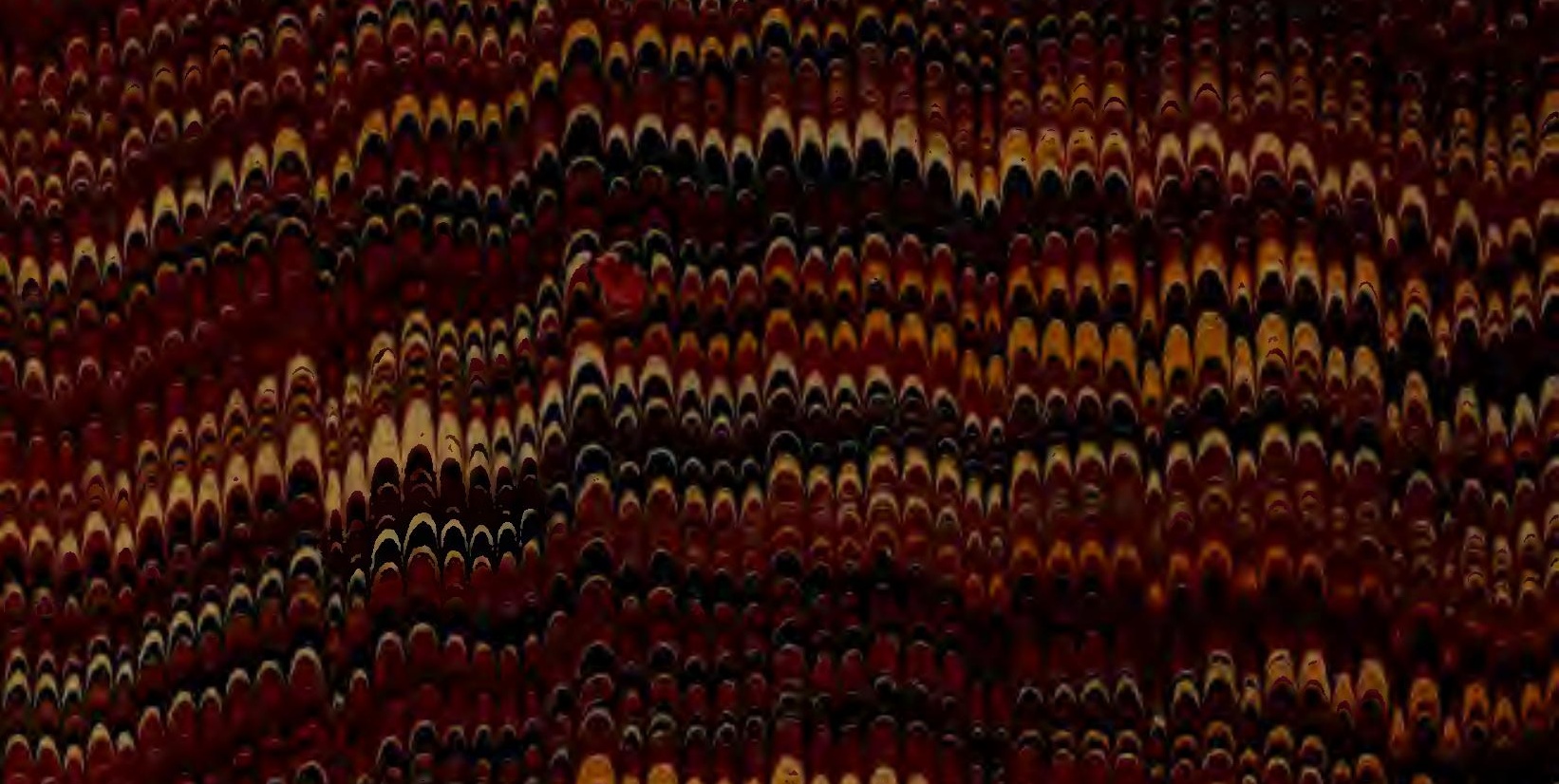
Afañ

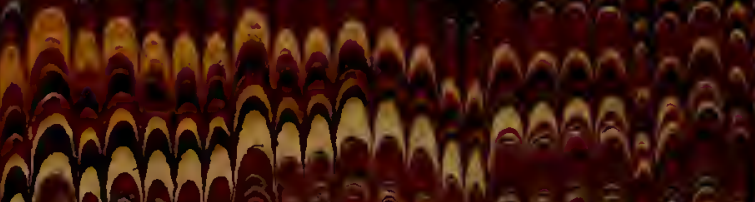

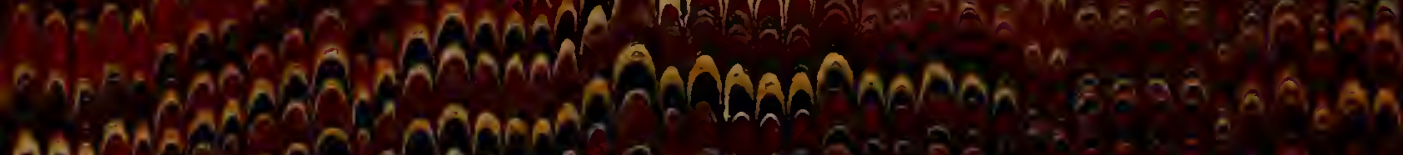
AAB AAAAĆ aAPANin?

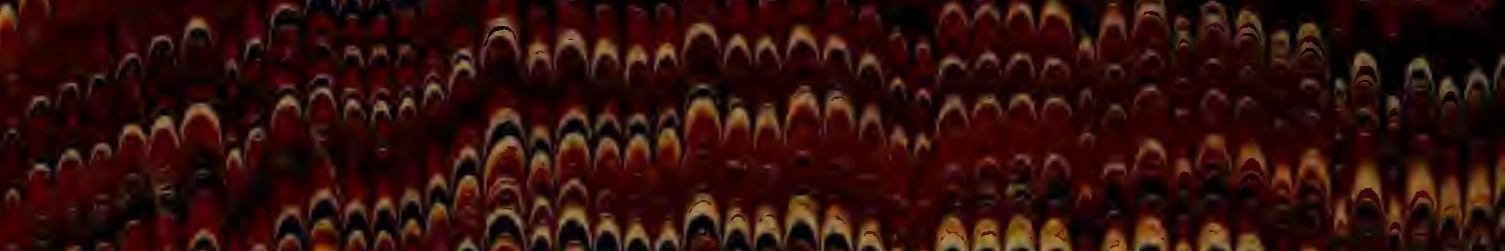

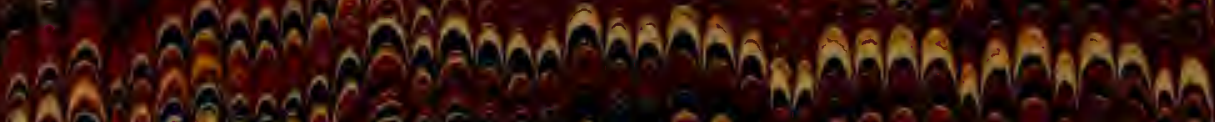

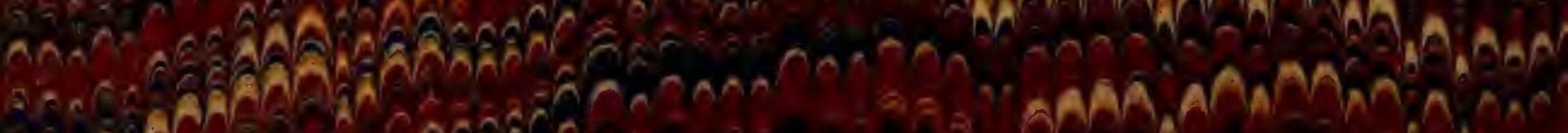

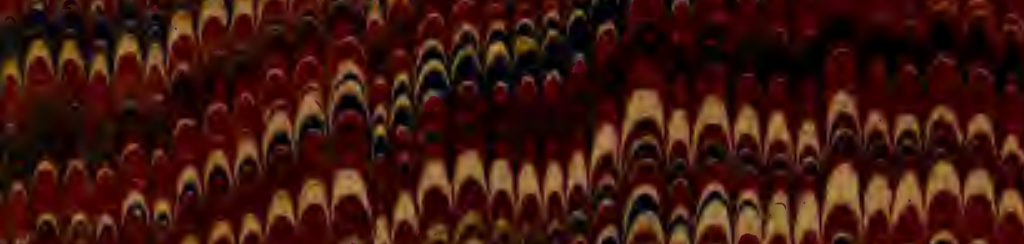
(8)

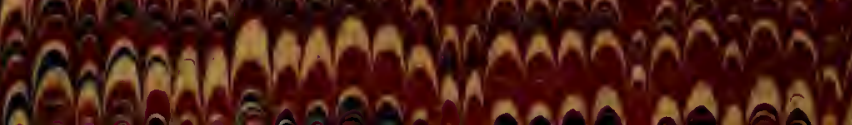




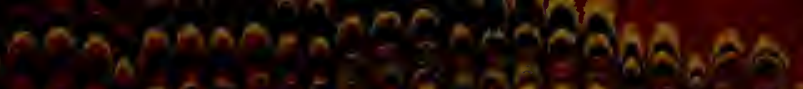

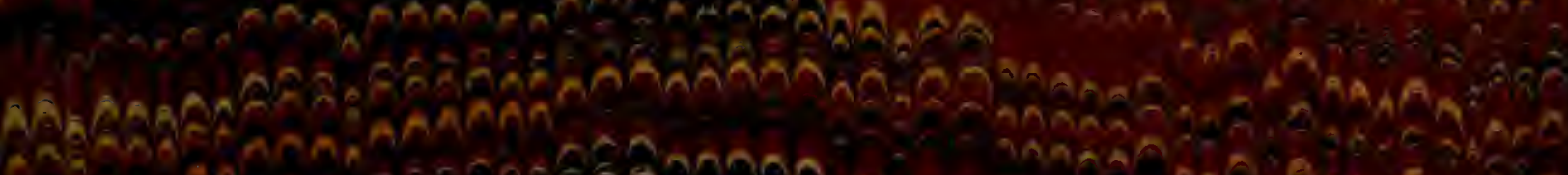

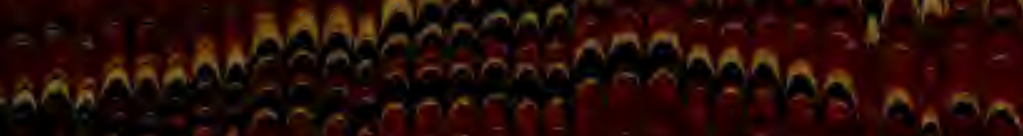

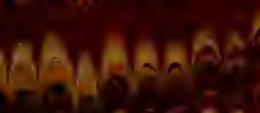

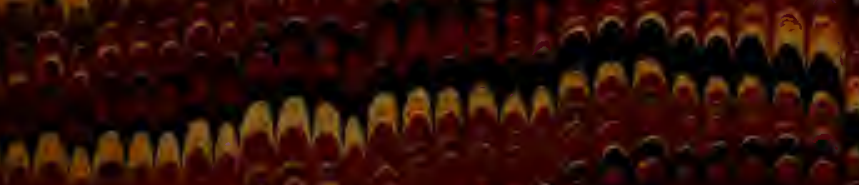

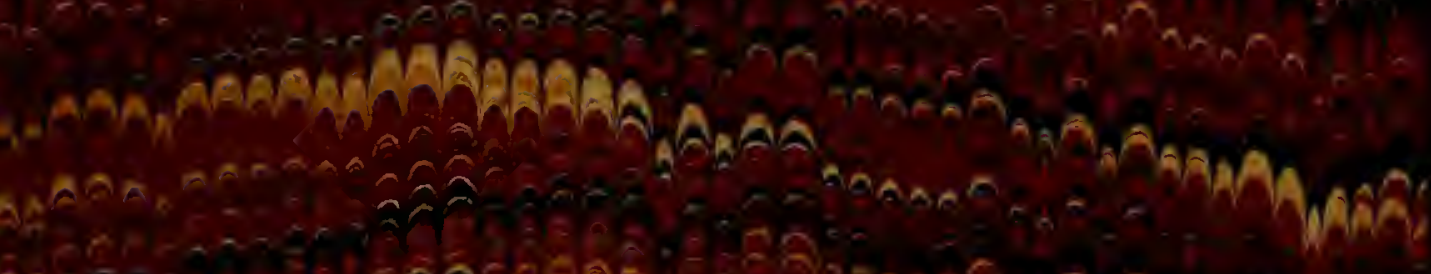
A

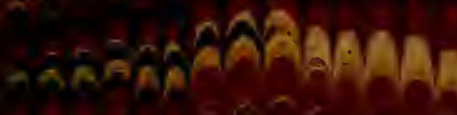

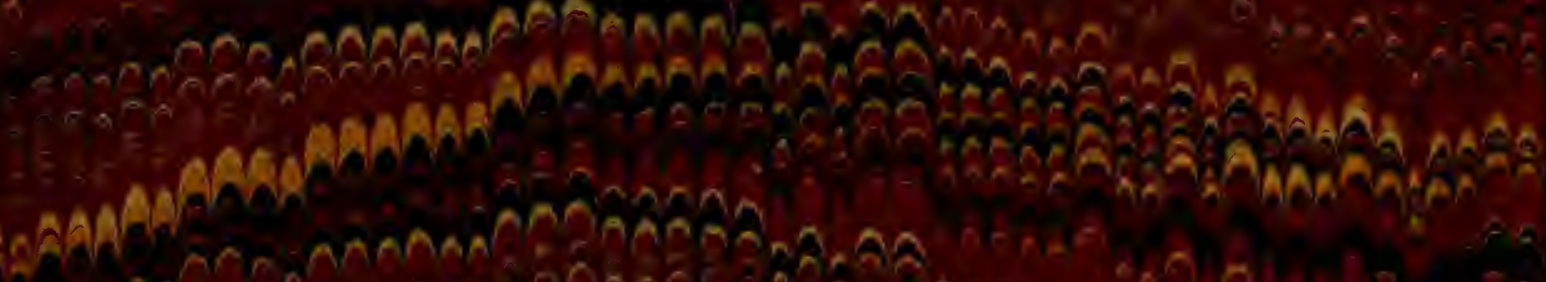

Thin

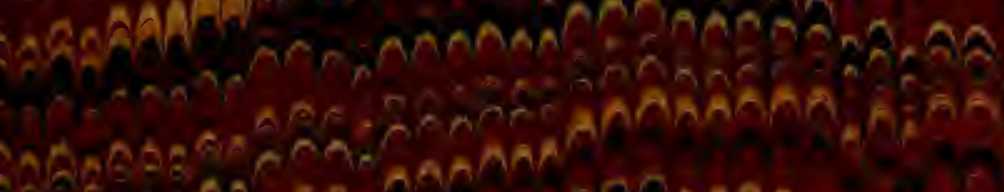

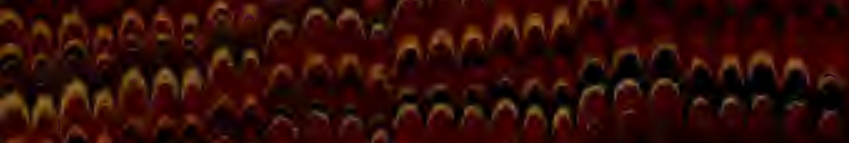

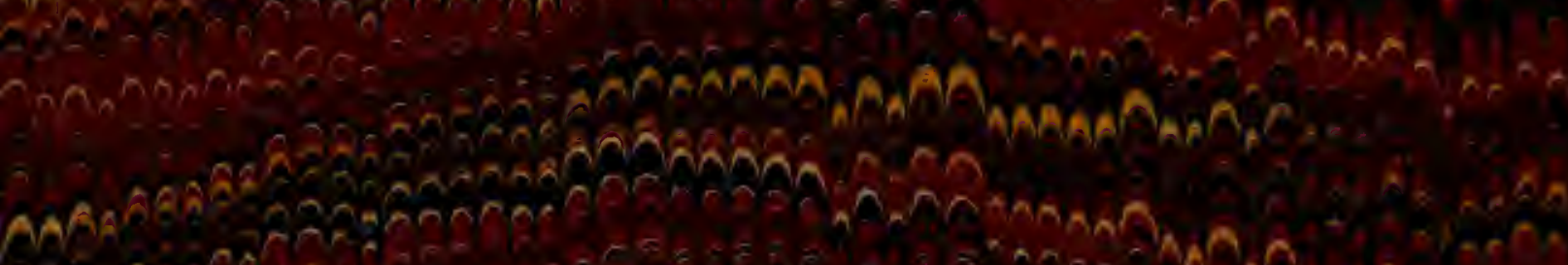

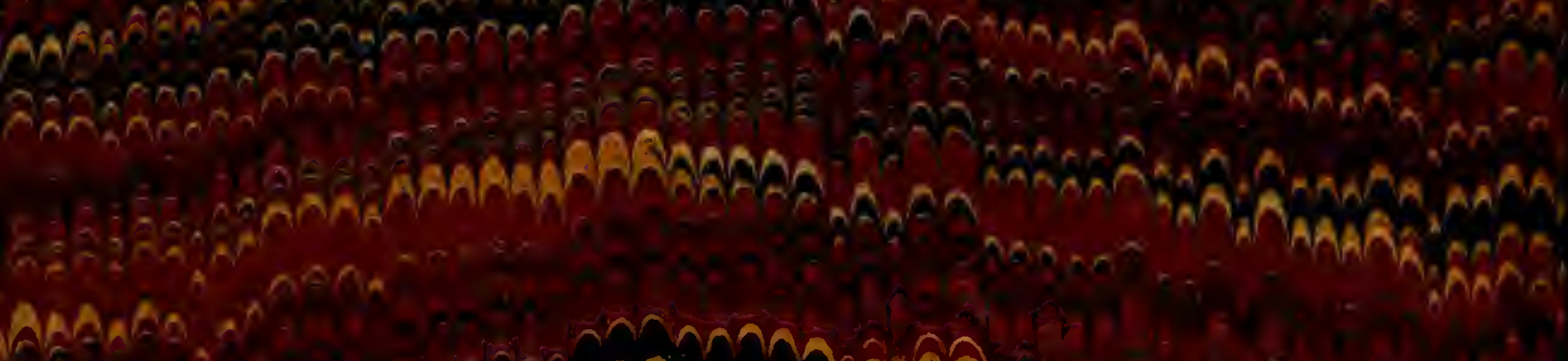




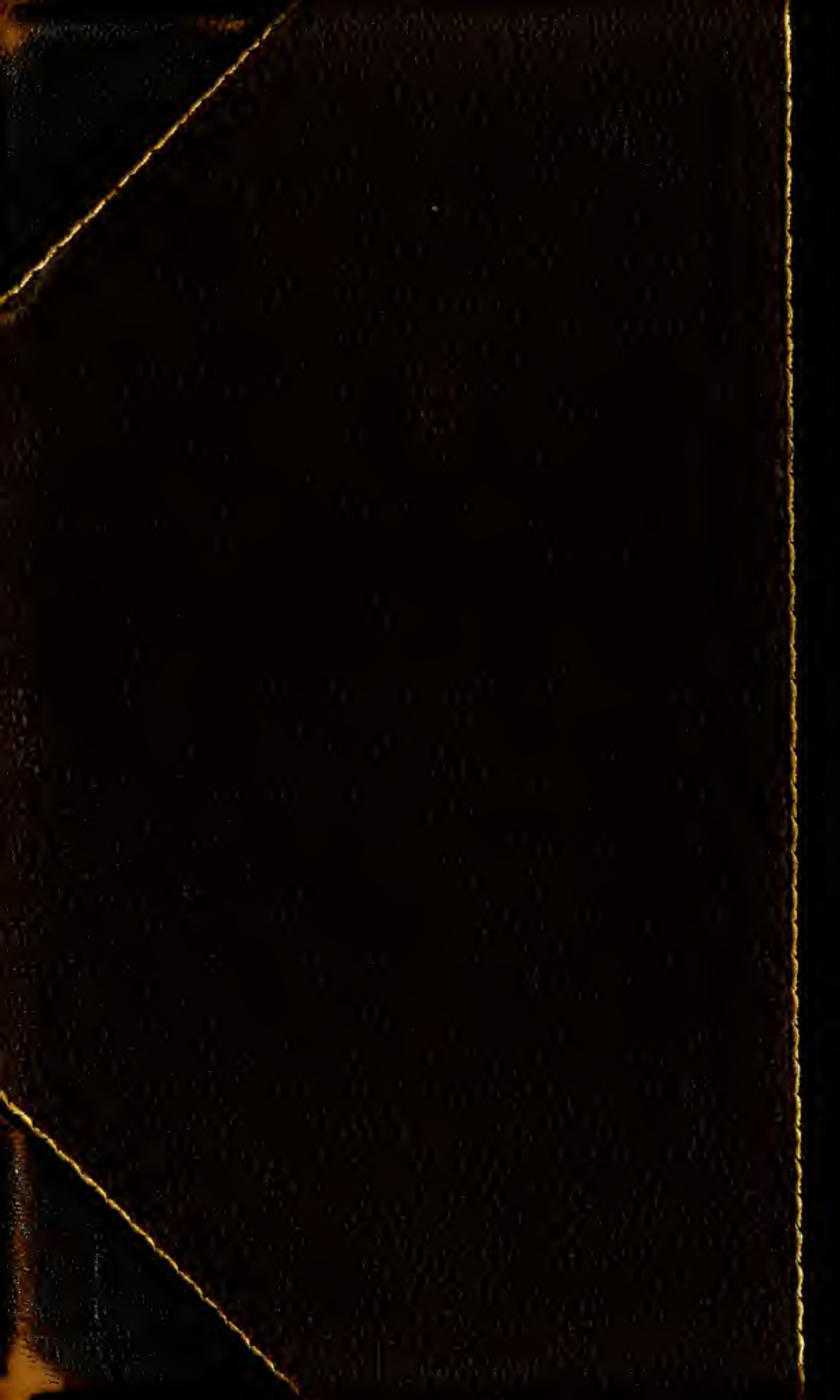

